UNIVERSIDADE DE SÃO PAULO

INSTITUTO DE GEOCIENCIAS

\title{
EVOLUÇÃO CRUSTAL E HISTÓRIA TECTÔNICA DOS GRANITÓIDES PERMO-TRIÁSSICOS DOS ANDES DO NORTE
}

César Javier Vinasco Vallejo

Orientador: Prof. Dr. Umberto Cordani

TESE DE DOUTORAMENTO

Programa de Pós-Graduação em Geoquímica e Geotectônica

\author{
SÃO PAULO \\ 2004
}


UNIVERSIDADE DE SÃO PAULO

INSTITUTO DE GEOCIÊNCIAS

\title{
EVOLUÇÃO CRUSTAL E HISTÓRIA TECTÔNICA DOS GRANITÓIDES PERMO-TRIÁSSICOS DOS ANDES DO NORTE
}

\author{
CÉSAR JAVIER VINASCO VALLEJO
}

Orientador: Prof. Dr. Umberto Giuseppe Cordani

TESE DE DOUTORAMENTO

COMISSÃO JULGADORA

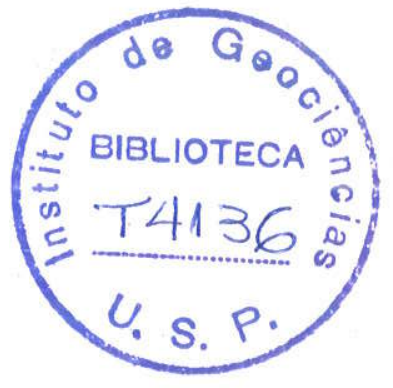

Assinatura

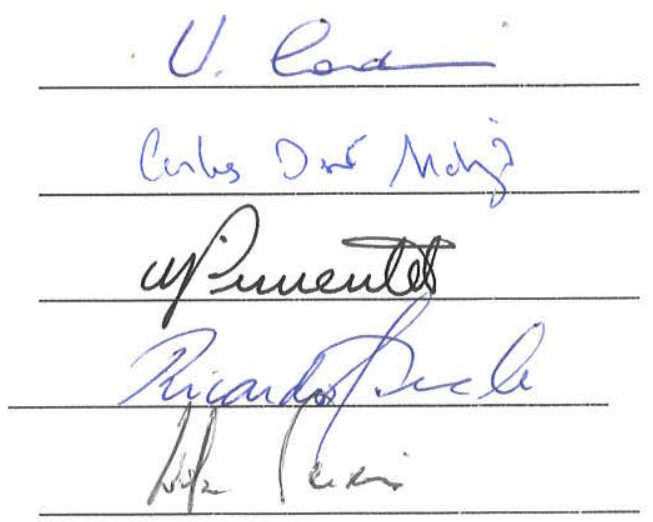

SÃO PAULO

2004 
UNIVERSIDADE DE SÃO PAULO

INSTITUTO DE GEOCIÊNCIAS

\title{
EVOLUÇÃO CRUSTAL E HISTÓRIA TECTÔNICA DOS GRANITÓIDES PERMO-TRIÁSSICOS DOS ANDES DO NORTE
}

\author{
César Javier Vinasco Vallejo \\ Orientador: Prof. Dr. Umberto Cordani
}
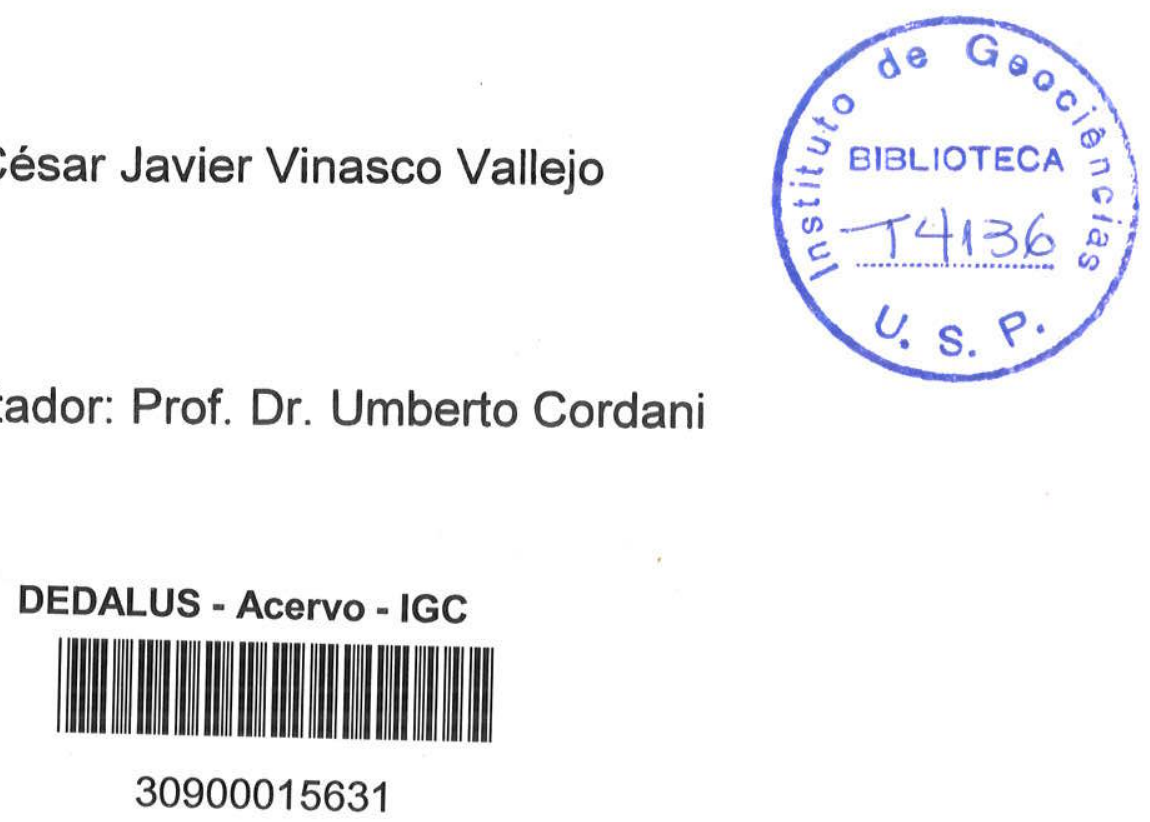

TESE DE DOUTORAMENTO

Programa de pós-graduação em Geoquímica e Geotectônica

SÃO PAULO

2004 
Ficha catalográfica preparada pelo Serviço de Biblioteca e Documentação do Instituto de Geociências da Universidade de São Paulo

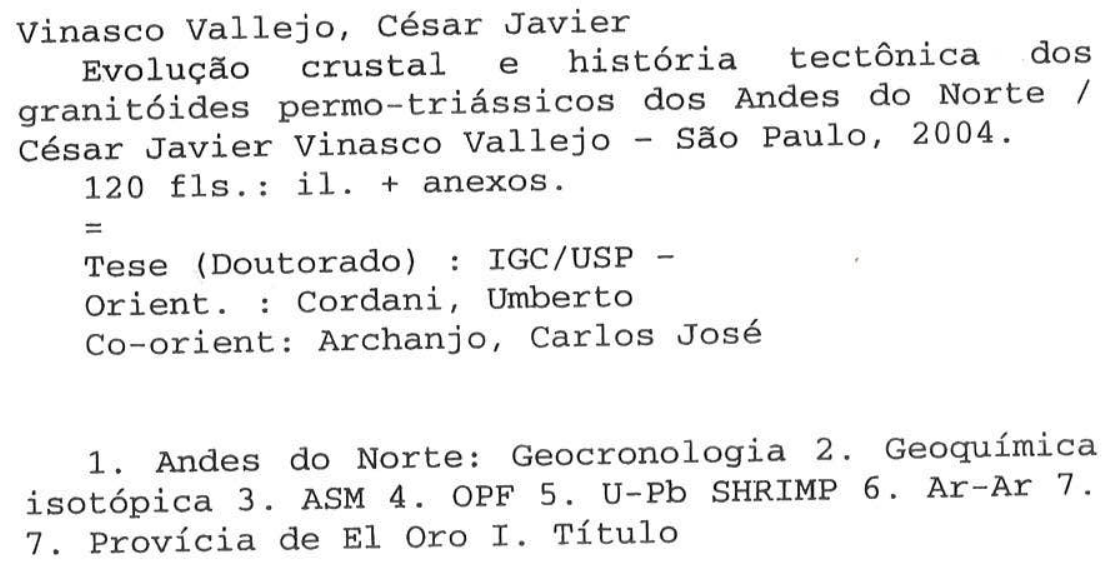

DOACAO POS GRARUARA

Data: $02 / 02 / 05$ 
Tu eres mi refugio, mi castillo, mi Dios, em quien confio 
En memória de mi queridísima abuela y de mi papá

\begin{abstract}
...ya no se encantarán tus ojos em mis ojos ya no se endulzará junto a ti mi dolor pero hacia donde vaya llevaré tu mirada y hacia donde camines llevarás mi dolor...
\end{abstract}

Para Michelle, mi linda y amada esposa

A mi familia que añoro 


\section{AGRADECIMENTOS}

Ao Prof. Dr. Umberto Cordani, pelo contínuo apoio, pela orientação precisa e inteligente, pela confiança, Ao Prof. Dr Carlos Archanjo, orientador do trabalho no mundo da ASM, pelo seu apoio e orientação,

À Fundação de Amparo à Pesquisa do Estado de São Paulo - FAPESP, pelo auxílio financeiro (Processo n. 01/05304-0),

Ao CNPQ pela ajuda financeira por meio do programa PROSUL,

A Prof. Dra Marly Babisnki, pelas análises de SHRIMP na China, por sua paciência e permanente colaboração,

Á Allen Nutman e Dunyi Liu pelas análises de U-Pb SHRIMP,

A Teresa Muñoz (Tere) e Santiago Vaca pelo trabalho de campo no Equador e por sua valiosa amizade,

A Arthur Onoe, por seu trabalho contínuo e sem descanso no laboratório de Ar-Ar; por sua amizade e pela força;

Ao Prof Dr. Ricardo Trindade pela ajuda e boa disposição no IAG,

Ao Curso de Pós-Graduação do Instituto de Geociências da Universidade de São Paulo por toda a infra-estrutura colocada à disposição e em especial ao pessoal do CPGeo pela contínua colaboração, especialmente a Verinha e aos professores Colombo Tassinari e Miguel Basei,

Agradeço também ao pessoal da secretaria da pós-graduação: Ana Paula e Magally pela sua boa disposição e a Tadeu pela ajuda permanente e amizade,

Ao Instituto de Investigación e Información Geocientífica, Minero-Ambiental y NuclearINGEOMINAS e em especial ao Prof. Humberto pelo apoio logístico durante parte do trabalho de campo,

Aos colegas e amigos Kika, Leo, Héicio, Lucelene, Marcia, Milene, Neivaldo, Guâno, Cintia, Valeria, Sergio, Eric, Marcela, Chris, Kelly, pela amizade durante todo este tempo,

A Alexandra pela sua colaboração no trabalho no IAG e leitura do texto, pela sua amizade sincera e cálida,

A Fernanda pela leitura do texto e correção do portuñol,

A turma colombo-chilena, pela sincera amizade, pelos jogos históricos e jogadas incriveis, por compartilhar tantos bons momentos: Agustin, colega de sala e desordem e Marcela; Andrés e Paula, Paul, Fercho, Mauro e Maria, Alejandro e Marta.

Finalmente agradeço à pessoa que mais sofreu, agüentou, ajudou e compartilhou em todas a fases do trabalho, Michelle, minha esposa. 


\section{SUMÁRIO}

RESUMO

ABSTRACT

INTRODUÇÃO

1. GEOLOGIA DOS ANDES DO NORTE 4

1.1. GENERALIDADES SOBRE OS ANDES SETENTRIONAIS 4

1.2. CONSIDERAÇOES SOBRE O ARCABOUÇO GEODINÅMICO REGIONAL PERMO-TRIÁSSICO

2. METODOLOGIA

2.1. MÉTODOS RADIOMETRICOS

2.1.1. U-Pb SHRIMP em zircão 8

2.1.2. Ar-Ar em biotita e anfibólio 10

2.1.3. Sm-Nd em rocha total 10

2.1.4. $\mathrm{Rb}-\mathrm{Sr}$ em rocha total 10

2.2. MÉTOdOS GEOQUIMIICOS 11

2.2.1. Análises FRX 11

2.2.2. Análises ICP-OES 11

2.3. ANISOTROPIA DE SUSCETIBILIDADE MAGNÉTICA (ASM) 12

2.4. ORIENTAÇÃO PREFERENCIAL. DE FORMA (OPF) 15

3. RESULTADOS E DISCUSSÃO 20

3.1. COMPLEXO METAMÓRFICO DE EL ORO 20

3.1.1. Geologia Regional 20

3.1.2. Geoquímica de elementos maiores, traço e ETR 27

3.1.3. Geologia Isotópica 29

3.1.4. Geocronologia 34

3.1.5. Estrutura e alojamento do Plutão de Marcabeli 54 
3.1.5.1. Resultados de ASM

3.1.5.2. Resultados da OPF

3.1.6. Comentários sobre a evolução

3.2. CORDILHEIRA REAL DO EQUADOR

3.2.1. Geologia Regional

3.2.2. Geologia Isotópica

3.2.3. Geocronologia

3.3. CORDILHEIRA CENTRAL DA COLOMBIA

3.3.1. Geologia Regional

3.3.2. Geoquímica de elementos maiores, traço e ETR

3.3.3. Geologia Isotópica

3.3.4. Geocronologia

3.3.5. Comentários sobre a evolução

4. CONSIDERAÇŐES FINAIS

5. REFERENCIAS 


\section{LISTA DE FIGURAS}

FIGURA 1. Sutura Herciniana.

FIGURA 2. Método de preparação de seções orientadas para estudo de ASM e OPF.

FIGURA 3. Representação de um objeto digitalizado para o cálculo do tensor de Inércia.

FIGURA 4. Casos simples de elipses e peso respectivo segundo a distribuição dos grãos na trama mineral.

FIGURA 5. Método de Interceptos.

FIGURA 6. QAP para as rochas do CM de El Oro e Cordilheira Real do Equador.

FIGURA 7. Indicadores cinemáticos de cisalhamento e relação dos granitóides com os encaixantes regionais.

FIGURA 7b. Relação dos granitóides e migmatitos com as encaixantes regionais.

FIGURA 8. Diagramas de Harker para os granitóides do CM de El Oro. 28

FIGURA 9. Variograma e diagrama das ETRs para os granitóides do CM de El Oro e Cordilheira Real do Equador.

FIGURA 10. Diagrama de correlação de Epsilon Nd vs. Epsilon Sr e curvas de evolução de $\mathrm{Nd}$ para as rochas do $\mathrm{CM}$ de El Oro.

FIGURA 11. U-Pb SHRIMP para o granitóide de Marcabeli.

FIGURA 12. U-Pb SHRIMP para o granitóide de La Florida.

FIGURA 13. Espectros de Ar-Ar para as rochas do CM de El Oro.

FIGURA 14. U-Pb SHRIMP para o granitóide de La Bocana.

FIGURA 15. U-Pb SHRIMP para os metassedimentos da Unidade La Victoria.

FIGURA 16 U-Pb SHRIMP para os metassedimentos de La Bocana. 53

FIGURA 17. Mapa estrutural do CM de El Oro.

FIGURA 18. Mapa do plutão de Marcabeli mostrando as zonas de dominância magmática, transicional e milonítica.

FIGURA 19. Localização de pontos para estudo de ASM e OPF plutão de Marcabelí.

FIGURA 20. Mapa de lineação e foliação magnética para o plutão de 
Marcabeli.

FIGURA 21. Curvas termomagnéticas para duas amostras do plutão de Marcabelí.

FIGURA 22. Parâmetros magnéticos para o plutão de Marcabelí.

FIGURA 23. Dados direcionais de ASM e OPF para o plutão de Marcabelí.

FIGURA 24. Diagrama de $\mathrm{CaO} / \mathrm{Na}_{2} \mathrm{O}$ vs. $\mathrm{Al}_{2} \mathrm{O}_{3} / \mathrm{TiO}_{2}$ para as rochas do $\mathrm{CM}$ de El Oro, Cordilheira Real e Cordilheira Central da Colômbia.

FIGURA 25. Espectros de Ar-Ar para rochas da Cordilheira Real do Equador.

FIGURA 26. QAP para os granitos gnáissicos e stocks graníticos da Cordilheira Central da Colômbia.

FIGURA 27. Diagramas de Harker para os granitos gnáissicos da Cordilheira Central da Colômbia.

FIGURA 28. Variograma e diagrama das ETRs para os granitos gnáissicos da Cordilheira Central da Colômbia.

FIGURA 29. Diagrama de correlação de Epsilon Nd vs. Epsilon Sr e curvas de evolução de Nd para as rochas da Cordilheira Central da Colômbia.

FIGURA 30. U-Pb SHRIMP para o granito gnáissico do Rio Verde.

FIGURA 31. Espectros de Ar-Ar para o gnaisse de La Miel, granito gnáissico de Manizales e anfibolito de Padua.

FIGURA 32. U-Pb SHRIMP para o gnaisse de La Miel.

FIGURA 33. U-Pb SHRIMP para o granito gnáissico de Palmitas.

FIGURA 34. U-Pb SHRIMP para o gnaisse de Abejorral.

FIGURA 35. U-Pb SHRIMP para o stock de Amagá.

FIGURA 36. Diagrama de correlação de Epsilon Nd vs. Epsilon Sr e curvas de evolução de $\mathrm{Nd}$ para as rochas granitóides permo-triássicas dos Andes do Norte. 


\section{RESUMO}

O objetivo geral deste trabalho é entender a origem e significado geodinâmico dos granitóides e ortognaisses variavelmente deformados que aparecem ao longo dos Andes do Norte, particularmente no Complexo Metamórfico de El Oro (CM de El Oro) ao sudoeste do Equador e na parte norte da cordilheira Central da Colômbia. Os métodos utilizados durante a pesquisa incluem U-Pb SHRIMP em zircão, Ar-Ar em micas e anfibólio, análises isotópicas $\mathrm{Nd}-\mathrm{Sr}$ e finalmente análises geoquímicas para elementos maiores, traço e ETRs em rocha total tanto para os granitóides quanto para metassedimentos. Adicionalmente, foi realizado um estudo estrutural a través dos métodos de Anisotropia de Suscetibilidade Magnética (ASM) e Orientação Preferencial de Forma (OPF) para o plutão de Marcabelí no $\mathrm{CM}$ de El com a finalidade de mostrar o mecanismo preferencial de colocação dos granitóides triássicos nesta parta da cadeia.

Os resultados analíticos para os granitóides crustais fortemente peraluminosos do CM de El Oro, Cordilheira Real do Equador e parte norte da Cordilheira Central da Colômbia, sugerem a presença de uma orogenia colisional no Permo-Triássico nos Andes do Norte relacionada à construção do supercontinente Pangea. Este evento estaria sendo registrado na Colômbia e Equador por idades de metamorfismo U-Pb SHRIMP em zircões herdados ao redor de $280 \mathrm{Ma}$ e idades magmáticas U-Pb-SHRIMP em zircões neoformados ao redor de $250 \mathrm{Ma}$, em granitóides sintectônicos de tipo dominantemente crustal. Por outro lado, idades magmáticas U-Pb SHRIMP em zircão a $235 \mathrm{Ma}$ e idades triássicas de resfriamento Ar-Ar entre 228-218 Ma nos granitóides do CM de El Oro e nos stocks graníticos da Cordilheira Central da Colômbia indicam a presença de um magmatismo crustal com aporte mantélico relacionado ao colapso orogenético e inicio do processo de disgregação do supercontinente. Adicionalmente, idades Ar-Ar concordantes (220 Ma) em metassedimentos no $\mathrm{CM}$ de $\mathrm{EI}$ Oro indicam que o resfriamento regional foi nesta época.

Os resultados da ASM e OPF no plutão de Marcabelí, um granitóide triássico do $\mathrm{CM}$ de $\mathrm{El}$ Oro, sugerem que os granitóides desta idade na zona foram colocados sintectonicamente em sistemas transcorrentes destrais. Idades U-Pb SHRIMP em zircão de $234 \mathrm{Ma}$ e idades de resfriamento Ar-Ar de aproximadamente 226 Ma no plutão de Marcabelí, por sua vez, sugerem uma taxa de resfriamento rápida para o plutão, sugestivo de um regime extensional regional. Idades Ar-Ar mais jovens em micas neoformadas obtidas em zonas 
miloníticas do plutão ao redor de $221 \mathrm{Ma}$, sugerem que o desenvolvimento da deformação foi praticamente contemporânea à colocação do corpo.

Durante o Permo-Triássico, a parte norte da cordilheira Central da Colômbia, O CM de El Oro e possivelmente a cordilheira Real do Equador, estariam localizados na parte frontal do Gondwana durante a orogenia Aleganiana. 


\section{ABSTRACT}

The general aim of this work is to understand the origin and geodinamic significance of the deformed granitoids and ortogneisses that appear along the northern Andean chain, particularly in the El Oro Metamorphic Complex (El Oro MC) southwestern Ecuador and northern part of the Central Cordillera of Colombia. The methods employed during this work include U-Pb SHRIMP in zircon, $\mathrm{Ar}-\mathrm{Ar}$ in micas and amphiboles, $\mathrm{Nd-Sr}$ isotopic and major, trace and REE geochemical analysis in whole rock samples for granitoids and metasediments. Additionally, structural analysis through Anisotropy of Magnetic Susceptibility (AMS) and Shape Preferred Orientation (SPO) methods for the Marcabeli pluton in the El Oro MC indicate the preferential mode of emplacement of triassic granitoids in this part of the chain.

Analytical results from the strongly peraluminous granitoids in the El Oro MC, Cordillera Real of Ecuador and northern part of Central Cordillera of Colombia, suggest the presence of a collisional orogeny in permo-triassic times in the Northern Andes related to the construction of the Pangea supercontinent. This event is recorded in Colombia and Ecuador by metamorphic U-Pb SHRIMP ages in inherited zircons around $280 \mathrm{Ma}$ and magmatic U-Pb SHRIMP ages in neoformed zircons around $250 \mathrm{Ma}$ in syn-tectonic crustal granitic gneisses and granitoids. On the other hand, magmatic U-Pb SHRIMP around $235 \mathrm{Ma}$ and cooling Ar-Ar triassic ages between 228-218 Ma Ma in granitoid rocks in the El Oro Metamorphic Complex, as well as in the granitic stocks of the northern part of the Central Cordillera of Colombia, indicate the presence of a late-tectonic magmatism related to orogenic collapse and the beginning of gragmentation of the supercontinent. Additionally, $\mathrm{Ar}-\mathrm{Ar}$ ages in micas and amphiboles from metasediments of the El Oro MC indicate regional cooling at this time.

AMS and SPO results in the Marcabeli pluton of the El Oro MC, suggest that triassic granitoids in the area were emplaced sintectonically within transcurrent dextral shear zones. U-Pb SHRIMP zircon ages about $234 \mathrm{Ma}$ and Ar-Ar mica cooling ages about $226 \mathrm{Ma}$ in the Marcabeli pluton indicate a rapid cooling rate, suggestive of a extensional regime. Younger $\mathrm{Ar}-\mathrm{Ar}$ ages in neoformed micas from the mylonitic granitoid, of about $221 \mathrm{Ma}$, suggest that the development of the deformation was practically contemporaneous with the emplacement of this magmatic body.

During the permo-triassic times, the northern part of the Central Cordillera of Colombia, the El Oro MC and possibly the Cordillera Real of 
Ecuador would have been located at the leading edge of Gondwana during the Alleganian orogeny. 


\section{INTRODUÇÃO}

Os períodos Paleozóico Superior e Mesozóico Inferior estão caracterizados nos Andes do Norte pela configuração do Supercontinente Pangea a partir da colisão Alleganiana entre Laurentia e Gondwana ocidental. Neste contexto geodinâmico os corpos magmáticos Permo-Triássicos que aparecem na Cordilheira Central da Colômbia, Cordilheira Real e província de El Oro no Equador seriam traçadores cronológicos, geoquímicos e paleo-geográficos do processo orogenético regional.

A parte principal do trabalho compreende o estudo das rochas que fazem parte do denominado Complexo Metamórfico de El Oro (CM de El Oro), sudoeste de Equador. Com estes corpos pretende-se obter as informações mais relevantes para o entendimento do modelo evolutivo da zona por meio do estudo de geoquímica convencional e isotópica, geocronologia e estudo de anisotropia magnética dos corpos magmáticos triássicos. Além disso, foram efetuados trabalhos regionais tanto na Cordilheira Real equatoriana quanto na Cordilheira Central colombiana, para efeitos de correlação e apresentação de um modelo para a geração dos corpos magmáticos do Mesozóico Inferior nesta parte dos Andes do Norte.

Este trabalho apresenta análises Ar-Ar em cristais individuais de micas e anfibólios, fornecendo evidência da história termal regional, e determinações $\mathrm{U}-\mathrm{Pb}$ SHRIMP (Sensitive High Resolution Ion Microprobe) em zircão, providenciando informação sobre as épocas de cristalização e história geológica anterior para os granitóides, além de idades máximas de deposição dos metassedimentos. São obtidas adicionalmente análises isotópicas de $\mathrm{Nd} \mathrm{e}$ $\mathrm{Sr}$ as quais, junto com análises de geoquímica convencional em rocha total são indicativas dos processos crustais dominantes na região. Por fim, um trabalho estrutural de Anisotropia de Suscetibilidade Magnética (ASM) e estudo de Orientação Preferencial de Forma (OPF) nos granitóides do Equador, permite definir o seu mecanismo preferencial de colocação.

As metas propostas neste trabalho são (1) a obtenção de um modelo geral sobre a evolução e significado geotectônico dos corpos magmáticos permotriássicos na parte norte da cadeia Andina, usando ferramentas estruturais, geocronológicas e geoquímicas; (2) a obtenção de idades por métodos radiométricos de corpos chaves para o entendimento da evolução préMesozóica da cadeia Andina e por fim, (3) determinar a temporalidade da 
colocação do granitóide de Marcabelí, no Equador, com relação aos eventos tectono-metamórficos regionais.

Com o objetivo de se obter comparações regionais no magmatismo permotriássico dos Andes do Norte, os granitóides foram agrupados da seguinte forma (encarte 1):

- Granitóides do CM de El Oro, sudoeste de Equador, incluindo os granitóides de La Bocana, Marcabeli, La Florida e El Prado (encarte 2).

- Granitóides e ortognaisses da Cordiheira Real do Equador.

- Granitóides e ortognaisses do flanco leste da Cordilheira Central da Colômbia (encarte 3)

- Granitóides e ortognaisses do flanco oeste da Cordilheira Central da Colômbia (encarte 3).

A bibliografia fundamental consultada corresponde a trabalhos das décadas de 80 e 90 tanto de cartografia básica quanto de interpretação geológica regional. Destacam-se os trabalhos de Restrepo (1986), Restrepo et al. (1978, 1989, 1991) e Restrepo e Toussaint $(1982,1984,1988)$ onde são discutidas as idéias sobre a evolução geológica da Cordilheira Central da Colômbia e é apresentado um número significativo de datações radiométricas pelos métodos $\mathrm{K}$-Ar e Rb-Sr. Outros trabalhos de destaque na Colômbia correspondem aos trabalhos de McCourt et al. (1984), os trabalhos de cartografia regional de González (1980, 2000), González et al. (1988) e o estudo sobre a evolução estrutural da parte norte dos Andes colombianos por Irving (1975). Recentemente, Ordoñez (2001) na sua tese de doutorado, apresenta uma caracterização isotópica $\mathrm{Rb}-\mathrm{Sr}$ e $\mathrm{Sm}-\mathrm{Nd}$ dos principais eventos magmáticos nos Andes colombianos com um número importante de dados geocronológicos e isotópicos. No Equador, os trabalhos mais importantes são os realizados dentro do Cordillera Real Geological Research Project (1986-1993), um convênio bilateral entre a Corporación de Desarrollo e Investigación GeológicoMinero Metalúrgica (CODIGEM) do Equador e o British Geological Survey (BGS). O projeto consistiu no mapeamento de reconhecimento da Cordilheira Real e da região de El Oro, incluindo trabalhos de geoquimica, geocronologia e estudos de geologia econômica. Os resultados são apresentados individualmente por Aspden et al. (1992a, b) e Aspden et al. (1995) e resumidos por Litherland et al. (1994). Finalmente, trabalhos clássicos sobre a evolução geológica da Cordilheira Real e a região de El Oro são apresentados por Feininger (1978, 1982, 1987), Baldock (1982), Hall e Calle (1982), Kennerly 
(1973, 1980) entre outros. Mourier (1988), apresenta um estudo sobre a aloctonia do terreno Amotape no norte do Peru com base em métodos paleomagnéticos.

Os trabalhos da evolução permo-triássica regionais mais relevantes são apresentados por Pindell e Dewey (1982) e Pindell (1985) nos artigos sobre a reconstrução permo-triássica do Pangea Ocidental e as reconstruções alleganianas da região do Golfo de México respectivamente; Dalziel et al. (1994) no trabalho sob a interação paleozóica Laurentia - Gondwana, Mégard (1987), em uma revisão regional dos Andes ao norte de Arica e Jaillard et. al. (1990) que apresenta um modelo de evolução geodinâmica dos Andes Centrais e do Norte.

A maior parte das amostras analisadas neste estudo foram coletadas durante trabalho de campo no Equador e na Colômbia no segundo semestre de 2002. São rochas da parte norte da Cordilheira Central de Colômbia, da Cordilheira Real e principalmente do Complexo Metamórfico de El Oro no Equador. 


\section{GEOLOGIA DOS ANDES DO NORTE}

A Cordilheira dos Andes caracteriza-se pelo cinturão magmático andino, os cinturões dobrados com vergência para leste $e$ as cordilheiras paralelas à trincheira da América do Sul. Estas feições são geradas em resposta à subducção da placa oceânica Pacífico por baixo da placa da América do Sul e à sobreposição de estruturas antigas que apresentam ampla variação latitudinal. Esta variação permite a subdivisão dos Andes em: (i) Andes do Norte, desde o Caribe até os $3^{\circ} \mathrm{S}$; (ii) Andes de Huancabamba, entre os $3^{\circ} \mathrm{S}$ e os $8^{\circ} \mathrm{S}$ e por fim, (iii) Andes Centrais para o Sul (Mégard, 1987). A mais importante mudança geológica ao longo do cinturão andino ocorre entre os Andes Centrais e os Andes do Norte (Gansser, 1973), onde os primeiros, com direção NW são rotacionados para NNE a partir da deflexão de Huancabamba.

\subsection{GENERALIDADES SOBRE OS ANDES SETENTRIONAIS}

Os Andes do Norte são orógenos caracterizados pela colisão e acresção de terrenos exóticos de origem e idade diversa, em contraste com os Andes Centrais os quais parecem corresponder a orógenos relacionados exclusivamente à subducção de litosfera oceânica desde o Jurássico Inferior (Mégard, 1987).

Nos Andes do Norte, a Cordilheira é dividida em três grandes ramificações geologicamente independentes: Cordilheiras Oriental, Central e Ocidental na Colômbia e cordilheiras Ocidental e Real no Equador (encarte 1). A Cordilheira Ocidental e as serras costeiras compreendem seqüências oceânicas alóctones de rochas básicas e sedimentos marinhos cenozóicos e do Cretáceo Superior intrudidas e cobertas por rochas magmáticas cenozóicas (González et al., 1988; Aspden et al., 1987). A Cordilheira Oriental, limite leste da região andina colombiana é formada por um embasamento ígneo metamórfico continental polideformado de idade Precambriana a Paleozóico. Este embasamento é coberto por seqüências sedimentares paleozóicas a mesozóicas (González et al.,1988), de afinidade Gondwanica, com evolução geológica Grenviliana (Cordani et al., no prelo).

A Cordilheira Real equatoriana se bifurca na Colômbia para formar a Cordilheira Central e a Cordilheira Oriental. Este último bloco crustal compõe o Craton Amazônico equatoriano em termos de evolução pós-silúrica (Litherland, et al, 1994). A espinha dorsal dos Andes colombianos é formada pela 
Cordilheira Central que compreende um complexo polimetamórfico prémesozóico (Restrepo and Toussaint, 1982) (encartes 1 e 3). Consiste de rochas metamórficas de baixo a alto grau do Complexo Cajamarca (González, 2000); se encontra intrudido por batólitos mesocenozóicos e coberto por rochas vulcânicas de arco continental eocénico (Gonzalez, 1988; Restrepo e Toussaint, 1982).

A parte setentrional da Cordilheira Central colombiana, denominada terreno Tahami por Restrepo e Toussaint (1988), é correlacionável com o denominado terreno Loja que conforma a maior parte da Cordilheira Real e o CM de El Oro na parte SW do Equador formados por rochas metamórficas paleozóicas associadas com corpos foliados triássicos (Litherland et al., 1994).

\subsection{CONSIDERAÇŌES SOBRE O ARCABOUÇO GEODINÂMICO REGIONAL PERMO- TRIÁSSICO}

A reconstrução permo-triássica do Pangea ocidental caracteriza o fechamento completo do oceano proto-atlântico entre América do Norte e América do Sul acompanhada pela justaposição do bloco Yucatán entre os montes Ouachita e Venezuela (Pindell e Dewey, 1982). A sutura herciniana separa zonas de deformação de bacias de foreland e tectônica de empurrão na América do Norte, México e o bloco Chortis para o noroeste de zonas de atividade tectonomagmática incluindo América do Sul, o bloco Yucatán, Flórida e África para sudeste (Fig. 1) (Pindell e Dewey, 1982) e a Cordilheira Central da Colômbia. A Orogenia Alleganiana como modelada por Pindell e Dewey (1982), sugere um prolongado período de deformação e metamorfismo para as rochas de Yucatán, que ocupam uma zona de cisalhamento entre América de Norte e América do Sul desde o Devoniano Superior até o Permiano Inferior (Pindell, 1985). Dados adicionais para corroborar a hipótese da proximidade da parte NW de América do Sul e Laurentia no Devoniano são obtidos a partir da presença de fauna marinha na bacia Apalachiana dessa idade na Colômbia e na Venezuela (Pindell, 1985).

A cronologia da deformação alleganiana está definida pelos episódios colisionais na parte sul dos Apalaches com início no Misissipiano Superior até - Pensilvaniano Superior (330-317 Ma aprox.). Nas montanhas Ouachitas ocorreu entre o Atokaniano e o Desmoinesiano (310-300 Ma aprox.); no Marathon entre o Virgiliano e o Wolfcampaniano (290-270 Ma aprox.); e nos Huastecan no Permiano (280-255 ma aprox.) (Pindell e Dewey, 1982). A 


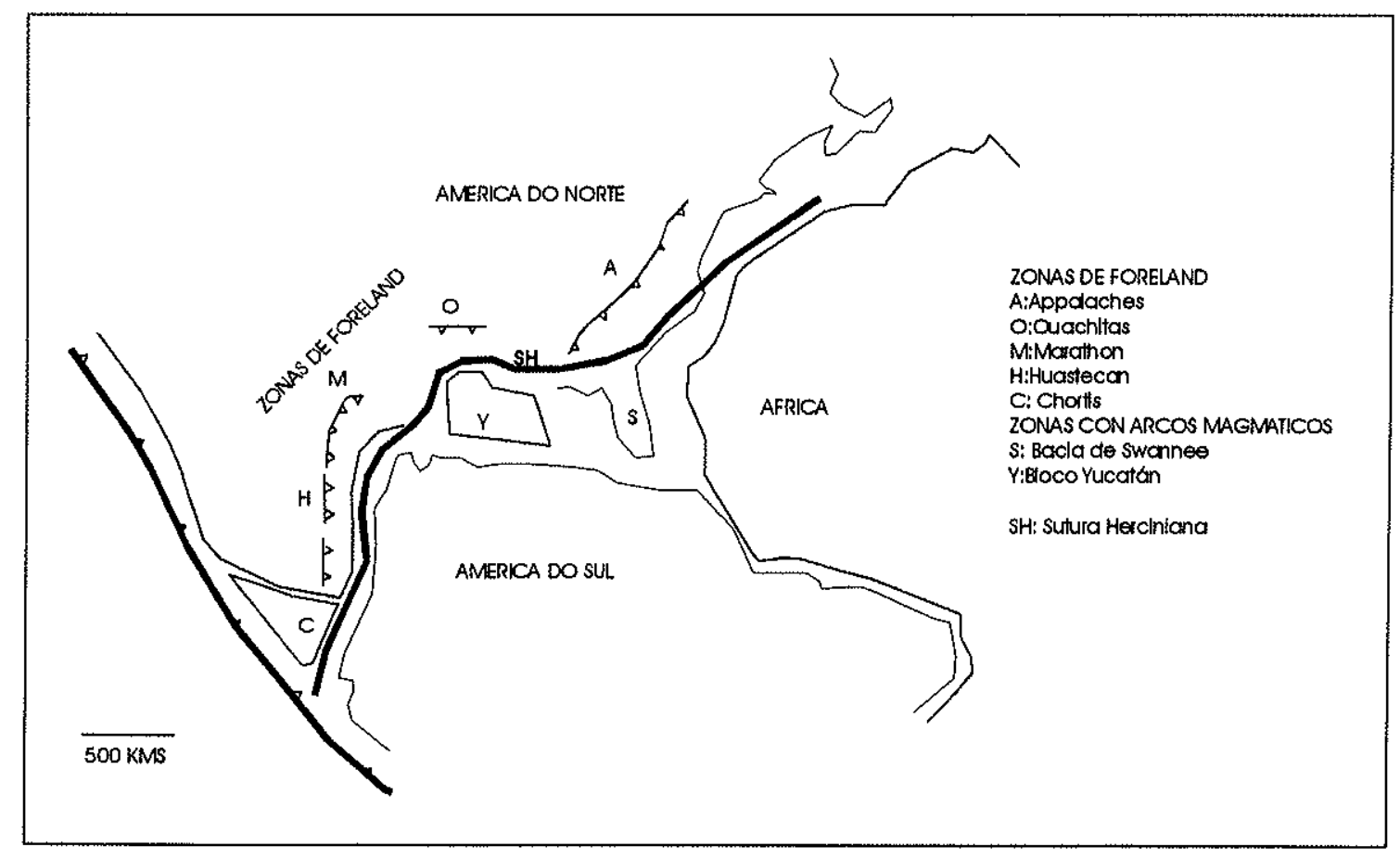

Figura. 1. Sutura herciniana separa (i) zonas de deformação em bacias de foreland e tectônica de empurramento em América do Norte, México e o bloco Chortis de (ii) zonas de atividade tectono-magmática incluindo América do Sul, o bloco Yucatán, Flórida e África para sudeste. Tomado de Pindell e Dewey, 1982. 
colisão permiana está registrada na parte norte da Cordilheira Central colombiana por uma série de dados geocronológicos em rochas metamórficas (encarte 4), por um magmatismo peraluminoso pós-colisional no limite permotriássico, e por um magmatismo pós-tectônico peraluminoso relacionado ao colapso orogênico no Triássico Médio a Superior.

Possiveis remanentes do arco magmático esperado pela subducção que causou à colisão alleganiana incluem granodioritos do Paleozóico Superior, andesitos e rochas vulcânicas encontradas no grupo Chuaucus de Guatemala, em rochas coletadas em furos de perfuração no Yucatán, na plataforma Coahuila, no alto Sabine e no embasamento de Flórida (Pindell, 1985). Estes fragmentos crustais teriam sido deixados atrás após o rifteamento triássico e jurássico que desagregou posteriormente o supercontinente. $O$ fechamento foi alcançado pela colisão oblíqua E-W desde o Devoniano Superior até o Permiano Médio com possível migração de vários blocos dentro da zona de sutura (Pindell, 1985). Embora Pindell (1985) mencione rochas desta idade na cordilheira Central da Colômbia como relacionadas ao evento de subducção, é possivel que estes pequenos corpos correspondam aos processos póscolisionais propriamente ditos e não aos processos prévios à colisão como será discutido adiante.

Aspden et al., (1992a), apresenta um modelo de cisalhamento triássico e anatexis ao longo de uma bacia de rift ensiálico para explicar a formação do que denomina o Cinturão metamórfico triássico dos Andes do Norte, fragmentos do qual compreendem o terreno Loja da Cordilheira Real, os terrenos Amotape (Complexo Metamórfico de El Oro) e Chaucha no Equador e o terreno Tahami da Cordilheira Central da Colômbia. Anfibolitos do Mesozóico Inferior presentes na Cordilheira Real e no $\mathrm{CM}$ de El Oro poderiam ser originalmente diques de basalto manto derivados relacionados a este evento de rifteamento. $O$ cinturão de metamorfismo e cisalhamento do Triássico Superior dos Andes do Norte marcariam o início do rifteamento que levou à separação do Gondwana e Laurentia e à formação do oceano Tethys (Jaillard et al., 1990, Aspden et al., 1992a). 


\section{METODOLOGIA}

O trabalho foi distribuido em cinco semanas de campo na província de El Oro, dois perfis na Cordilheira Real do Equador e dez dias de campo na Colômbia. Algumas das amostras obtidas para a Cordilheira Real do Equador foram coletadas e cedidas pelo professor Arturo Eguez da Escuela Politécnica Nacional de Quito e algumas amostras da Cordilheira Central da Colômbia foram cedidas pelo INGEOMINAS através do geólogo Humberto González.

O trabalho no Equador foi realizado a partir de mapas topográficos escala 1:50.000, disponiveis no Instituto Geográfico Militar (IGM) em Quito. O trabalho regional na Colômbia foi realizado a partir de mapas geológicos escala 1:250.000 disponiveis no INGEOMINAS.

Os métodos analíticos utilizados durante a pesquisa foram: geocronológicos Ar-Ar no Centro de Pesquisas Geocronológicas da Universidade de São Paulo (CPGeo-USP) e U-Pb SHRIMP-II na Australian National University (ANU) e na Academia Chinesa de Geociências; métodos isotópicos $\mathrm{Sr}$ e Nd no CPGeoUSP e métodos de geoquímica rocha total para elementos maiores, traço e ETRs no laboratório de química do Instituto de Geociências da Universidade de São Paulo (IGc-USP). Os métodos estruturais de pesquisa utilizados foram a Anisotropia de Suscetibilidade Magnética (ASM) no Laboratório de Paleomagnetismo no Instituto de Astronomia e Geofísica da Universidade de São Paulo (IAG-USP) e o método de orientação Preferencial de Forma (OPF) no Igc-USP soba orientação do Prof. Dr. Carlos Archanjo.

\subsection{MÉTODOS RADIOMÉTRICOS}

\subsubsection{U-Pb SHRIMP em zircão}

O método U-Pb SHRIMP em zircão permite a obtenção de idades de cristalização nos corpos ígneos além de mostrar possiveis heranças da evolução geológica pretérita. Nas rochas metassedimentares é possivel obter idades máximas de deposição e ainda idades de metamorfismo em zircões neoformados no caso de metamorfismo de alto grau. A datação U-Pb foi realizada em grăos individuais de zircão para 11 amostras, empregando o SHRIMP da Academia Chinesa de Geociências e da Research School of Earth Sciences (RSES) na ANU -SHRIMP II-. Os zircőes foram separados nos laboratórios de preparação de amostras do CPGeo-USP e montados em uma 
resina epóxica para medições isotópicas. Os detalhes dos procedimentos analíticos, incluindo métodos de calibração são apresentados por Williams (1998) e Stern (1998). Os dados analíticos são apresentados de forma gráfica em diagramas concórdia convencionais, gráficos de probabilidade relativa (relative probability plots) e gráficos de idade média ponderada (weighted average age plots) este último usando as idades obtidas a partir das razões ${ }^{206} \mathrm{~Pb} /{ }^{38} \mathrm{U}$ isotopicamente menos perturbadas (i.e que situam-se próximas da concórdia). $O$ tratamento dos dados é feito usando o programa Isoplot 3.0 de Ludwig (2003) com erro a nivel de confiança de $95 \%$. São reportadas também as idades médias e o MSWD (mean square of weighted deviates) para dados agrupados pertencentes aparentemente a uma única população, que possuem como característica probabilidades de ajuste maiores que 0,05 e MSDW perto ou menor que 1 . Valores de MSWD muito maiores que a unidade $e$ probabilidades de ajuste perto de zero indicam a presença de espalhamento dos dados não devida a erro analítico (i.e. diferentes populações). Finalmente são apresentadas imagens de catodo-luminescência quando disponiveis com os pontos de análise e idade ${ }^{206} \mathrm{~Pb} /{ }^{38} \mathrm{U}$.

Razões ${ }^{206} \mathrm{~Pb} /{ }^{238} \mathrm{U}$ têm um componente de erro tipicamente entre 1.5 e $2.0 \%$ por causa da calibração com os zircões usados como standard. A abundância de $U$ e a razão $U / P b$ são calibradas em relação ao zircão Sri-Lanka (SL-13) $\left({ }^{208} \mathrm{~Pb} /{ }^{238} \mathrm{U}=0.0928 ; 572 \mathrm{Ma}\right)$. As idades calculadas neste trabalho são idades ${ }^{206} \mathrm{~Pb} /{ }^{238} \mathrm{U}$ corrigidas por $\mathrm{Pb}$ comum com base em ${ }^{204} \mathrm{~Pb}$ medido. Os dados isotópicos são obtidos com um erro de 1-sigma e a obtenção das idades médias ponderadas são obtidas com um erro de 2-sigma. As idades consideradas adequadas para a discussão geológica são as idades aparentes ${ }^{206} \mathrm{~Pb} /{ }^{238} \mathrm{U}$ por serem estas mais precisas do que as idades ${ }^{207} \mathrm{~Pb} /{ }^{235} \mathrm{U}$ (Vavra et al., 1996). Adicionalmente, dados ${ }^{207} \mathrm{U} /{ }^{206} \mathrm{U}$ para zircões com idades menores do que $800 \mathrm{Ma}$ são normalmente pouco precisos para relacioná-los diretamente à concórdia devido à diminuição da curvatura desta com o decréscimo na idade (Compston, 1999), portanto a porcentagem de discordância (idades $206 / 238$ vs. 207/266) não é um critério confiável de discriminação de qualidade no caso de estudo, sendo que os resultados considerados aceitáveis para discussão são aqueles que situam-se diretamente sobre a curva concórdia. 


\subsubsection{Ar-Ar em biotita e anfibólio}

As análises Ar-Ar pela técnica de aquecimento por etapas permitem obter evidências sobre a historia termal regional e sobre idades deformacionais no caso de milonitos desenvolvidos nas fácies xisto verde (Reddy e Potts, 1998). Foram preparadas 42 amostras de rocha para separação de micas e anfibólios para análise no laboratório de Ar-Ar no CPGeo-USP. Entre 15 e 20 cristais individuais de cada amostra são irradiados no reator nuclear IEA-R1 no Instituto de Pesquisas Nucleares (IPEN) em São Paulo junto com o monitor de fluxo neutrônico (Sanidina Fish Canyon). Posteriormente dois ou três cristais são analisados pela técnica de aquecimento por etapas. A descrição do equipamento, procedimentos de laboratório e preparação de amostras, irradiação, análise e interpretação de resultados encontram-se em Vasconcelos et al., (2002). Adicionalmente, a descrição da metodologia ${ }^{40} \mathrm{Ar}$ ${ }^{39} \mathrm{Ar}$, bem como seu valor interpretativo são amplamente discutidas e apresentadas por vários autores, entre eles Dalrymple e Lanphere (1974), Merrihue e Turner (1966), Faure (1986), McDougall e Harrison (1999), Renne (2000), entre outros.

\subsubsection{Sm-Nd em rocha total}

Foram realizadas 32 análises Sm-Nd em RT no CPGeo-USP segundo os procedimentos descritos em Sato et al., (1995). Os procedimentos experimentais incluem digestão ácida da amostra e adição de um spike combinado de $\mathrm{Sm}-\mathrm{Nd}$, posterior separação de $\mathrm{Sm}$ e $\mathrm{Nd}$ numa coluna de intercâmbio iônico e finalmente medição de razões isotópicas em um espectrômetro de massa de ionização térmica equipado com sistema multicoletor. As idades modelo $\mathrm{Sm}-\mathrm{Nd} \mathrm{T}_{\mathrm{DM}}$ foram calculadas segundo o método de DePaolo et al. (1991). Os resultados obtidos são apresentados no encarte 5.

\subsection{4. $\mathrm{Rb}-\mathrm{Sr}$ em rocha total}

As 32 amostras utilizadas para análises $\mathrm{Sm}-\mathrm{Nd}$ foram utilizadas para análises $\mathrm{Rb}-\mathrm{Sr}$ e determinação de razões ${ }^{87} \mathrm{Sr} /{ }^{86} \mathrm{Sr}$ no CPGeo-USP. As determinações de ${ }^{87} \mathrm{Sr}-{ }^{86} \mathrm{Sr}$ são feitas no espectrômetro de massa VG-sector e corrigidas por fracionamento isotópico durante a ionização térmica usando o valor de ${ }^{87} \mathrm{Sr}$ ${ }^{86} \mathrm{Sr}=0.1194$. Os procedimentos laboratoriais seguem em geral os descritos em Tassinari et al. (1996). Os resultados são apresentados no encarte 5. No presente trabalho as determinações tanto de $\mathrm{Rb}$ quanto de $\mathrm{Sr}$ foram feitas por 
fluorescência de raios $X$, portanto a precisão na determinação da razão ${ }^{87} \mathrm{Rb} /{ }^{86} \mathrm{Sr}$ acima de $1 \%$ é obtida no intervalo entre 50 e $650 \mathrm{ppm}$ para ambos elementos.

Os diagramas de correlação isotópica Nd-Sr e curvas de evolução de Nd são tratados por meio de planilhas de Excel.

Para todos os métodos radiométricos, as constantes de decaimento utilizadas são as de Steiger e Jäger (1977).

\subsection{MÉTODOS GEOQUÍMICOS}

\subsubsection{Análises FRX}

Elementos maiores e traço para 30 amostras em rocha total foram determinados por fluorescência de raios $X$ no Laboratório de Química do Departamento de Mineralogia e Petrologia do IGc-USP. A preparação de amostras inclui micro-redução e obtenção de pastilhas prensadas para determinação de elementos maiores e fusão de material para obtenção de discos de fundido para determinação dos elementos traço. As amostras são analisadas em um espectrômetro de FRX Philips PW 2400 que apresenta limites de detecção geralmente na ordem de 1-10 ppm para elementos traço. Os procedimentos de preparação de amostras e laboratoriais seguem a metodologia descrita por Mori et al. (1999). Os resultados são apresentados no encarte 6 .

\subsubsection{Análises ICP-OES}

Elementos das Terras Raras (ETR) foram determinados para 25 amostras de rocha total no laboratório de ICP-OES (Inductively Coupled Plasma Optical Emission Spectroscopy) no Departamento de Mineralogia e Petrologia do IGcUSP. Amostras em pó foram fundidas com borato de lítio e dissolvidas em ácido hidroclórico. A separação das ETRs foi efetuada por meio de colunas de troca iônica utilizando ácido nítrico e hidroclórico. Análises subseqüentes foram realizadas no espectrômetro seqüencial ICP-OES, modelo ARL 3410, equipado com mini-tocha e nebulizador ultrasônico CETAC, modelo U-5000AT. Os procedimentos de análise seguem a metodologia apresentada em Navarro et al. (2002). Os resultados são apresentados no encarte 6. 


\subsection{ANISOTROPIA dE SUSCETIBILIDAdE MAGNÉtICA (ASM)}

A Anisotropia Magnética refere-se à variabilidade direcional de magnetização $(M)$ na presença de um campo indutor $(H)$, de forma que,

$\boldsymbol{M}=\boldsymbol{k} \boldsymbol{H}$,

onde $k$ é um parâmetro escalar denominado suscetibilidade magnética. Como $M$ e $H$ são expressos em ampere por metro, a suscetibilidade $k$ não tem dimensões e é expressa em unidades SI (Sistema Internacional).

A ASM é uma propriedade física das rochas usada para estudos estruturais e de petrofábrica (Hrouda, 1982; Rochette, et al., 1992; Borradaile e Henry, 1997.). A ASM tem sido amplamente utilizada no estudo de processos geológicos, particularmente na caracterização de fábrica de rochas igneas. As direções principais da ASM podem revelar as direções de fluxo de um magma, as direções da deformação finita de rochas tectonizadas, além da potencialidade de mostrar alguns aspectos do regime de deformação (Tarling e Hrouda, 1993).

A ASM depende da orientação preferencial de minerais magnéticos anisotrópicos, isto é, da fábrica magnética da rocha. A orientação preferencial dos eixos cristalográficos, que com freqüência controlam a forma dos grãos, determinam a ASM para a grande maioria dos minerais. No caso da magnetita, dada a sua alta suscetibilidade, a forma do grão prevalece sobre o controle cristalográfico, determinado assim a anisotropia do mineral.

O resultado de um estudo de ASM é um elipsóide de suscetibilidade magnética definido pela magnitude e orientação de seus três eixos principais, $k_{1} \geq k_{2} \geq k_{3}$. i.e., os três autovalores (eigenvectors) do tensor de suscetibilidade. Os parâmetros utilizados na descrição do elipsóide magnético são:

- a suscetibilidade média:

$$
k_{m}=\left(k_{1}+k_{2}+k_{3}\right) / 3 \text {, }
$$

- as razões de anisotropia:

$$
\begin{aligned}
& L=k_{1} / k_{2} \text { (lineação) } \\
& F=k_{2} / k_{3} \text { (foliação) e }
\end{aligned}
$$

- o grau de anisotropia:

$$
P=k_{1} / k_{3} \text { ou }
$$


$P^{\prime}=\exp \left[2 \times\left(n_{1}-n_{m}\right)^{2}+\left(n_{2}-n_{m}\right)^{2}+\left(n_{3}-n_{m}\right)^{2}\right]^{1 / 2}$

Onde $n_{1}, n_{2}, n_{3}=L n_{k 1}, L n_{k 2}, L n_{k 3}$

$n_{m}=1 / 3\left(n_{1}+n_{2}+n_{3}\right)$; quando $P=1$ (esfera) a suscetibilidade é isotrópica e, na medida em que $P$ aumenta, o grau de excentricidade do elipsóide aumenta.

- forma do elipsóide:

$T=\left[2\left(\operatorname{Ln~} K_{2}-\operatorname{Ln~} K_{3}\right) /\left(\operatorname{Ln~} K_{1}+\operatorname{Ln~} K_{3}\right)\right]-1 ; T$ varia de $>0$ a 1 para elipsóides de triaxiais a oblatos e de $<0$ a -1 para elipsóides de triaxiais a prolatos.

O valor de suscetibilidade consiste da soma das contribuições individuais e do teor dos minerais paramagnéticos, diamagnéticos e ferromagnéticos (S.I.). A anisotropia de suscetibilidade por sua vez, depende da forma do grão, tipo de retículo cristalino e da orientação espacial dos minerais.

Uma das suposições mais importantes em que baseia-se o estudo de ASM, com forte implicação nas considerações estruturais, é a coaxialidade do elipsóide de ASM à petrofábrica, onde o eixo $k_{3}$ é perpendicular à foliação e $k_{1}$ paralelo à lineação tectônica ou fluxo magmático. Desta forma, $k_{3}$ é denominado o pólo da foliação magnética e $k_{1}$ a direção da lineação magnética.

Estudos de ASM no plutão de Marcabeli CM de EI Oro, SW de Equador) foram efetuados para 56 amostras orientadas, e que correspondem a 28 pontos de amostragem (encarte $2 ;$ fig. 19). As amostras foram coletadas por meio de uma perfuratriz portátil, devidamente rotuladas, orientadas em campo e analisadas no laboratório de Paleomagnetismo do IAG-USP. A medida de ASM é feita em cilindros de rocha com tamanho padrão de $22 \mathrm{~mm}$ de altura por $22 \mathrm{~mm}$ de diâmetro obtidos em cilindros originais orientados no campo e de altura média de $7 \mathrm{~cm}$. A anisotropia de suscetibilidade pode ser determinada girando uma amostra em um campo magnético indutor (método rotativo), ou então medindo a suscetibilidade da amostra em 9 posições diferentes (protocolo de Girdler, 1961) ou em 15 posições diferentes (protocolo de Jelinek, 1977). As direções do elipsóide de suscetibilidade obtido são determinadas pelo sistema de coordenadas ortogonais da amostra, onde o eixo $x$ corresponde à declinação (azimute), o eixo $z$ à inclinação e o eixo $y$ é perpendicular ao plano $x z$ (Fig. 2). Para a obtenção do elipsóide de suscetibilidade magnética foi utilizado o equipamento MINISEP no IAG-USP que mede a anisotropia de suscetibilidade através do método rotativo. 

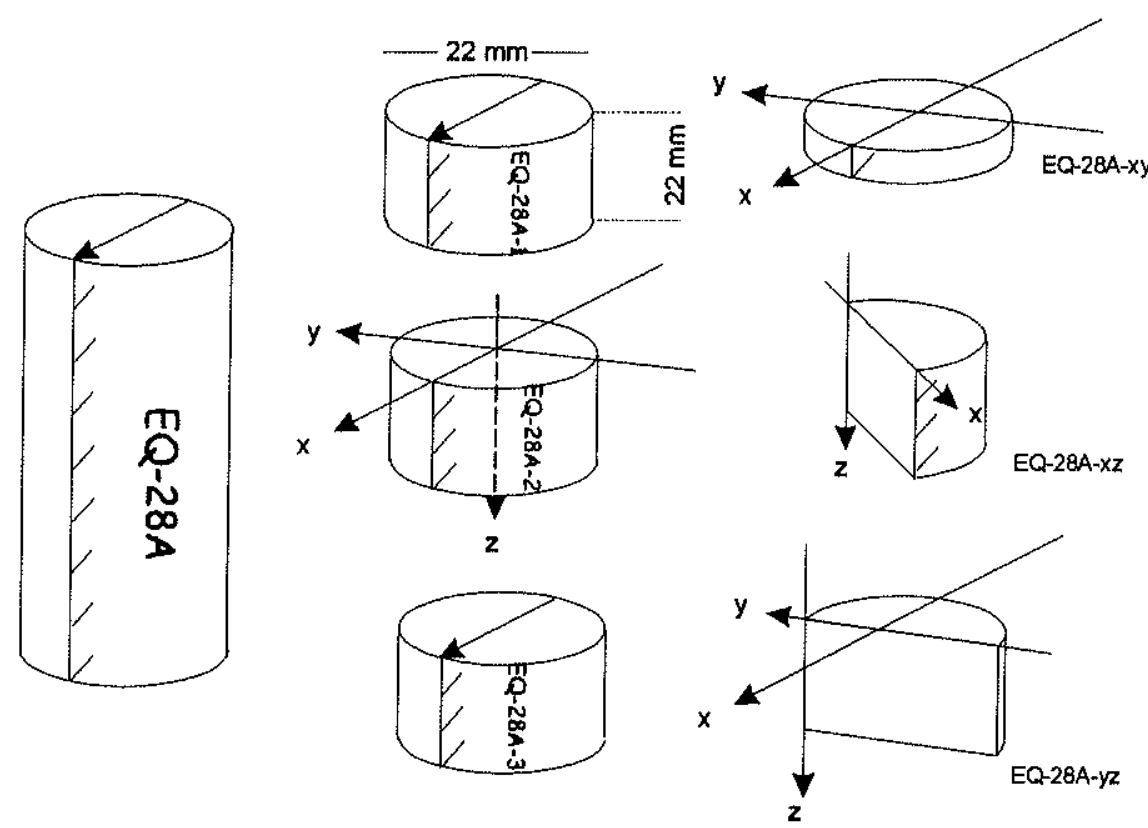

Figura. 2. Método de preparação de seções orientadas para estudo de ASM e OPF. 


\subsection{ORIENTAÇÃo PREFERENCIAL dE FORMA (OPF).}

Foi determinada a OPF de biotita em 9 sítios com o intuito de comparar a fábrica magnética com a fábrica mineral da rocha. A discussão teórica do método pode ser encontrada em Robin (2002) e Launeau e Robin (1996), e a rotina de trabalho aqui utilizada está detalhada em Archanjo (2002) e Archanjo e Launeau (2004).

O elipsóide de trama mineral é obtido a partir do conhecimento de elipses seccionais (2D) medidas em três superficies perpendiculares obtidas por corte de cilindros orientados de rocha (Fig. 2). O estudo baseia-se na aquisição e tratamento de imagens para separação digital das fases minerais de interesse e posterior cálculo das elipses (2D) e do elipsóide (3D) representativo da trama mineral.

A aquisição digital das imagens é feita com uma cámera tri-CCD (Charged Coupled Device) colorida, acoplada a um microscópio petrogáfico. O sistema é gerenciado pelo software Geovision version 3.1 (Fueten, 1997). Ele fornece um conjunto de imagens petrográficas em luz natural ou polarizada, cada imagem formada pela superposição de 89 sub-imagens obtidas pela rotação do polarizador a intervalos de $1.25^{\circ}$. Consequentemente, na imagem final, dado $o$ alto pleocroismo da biotita, a fase de interesse neste trabalho, é possivel obter uma imagem com máxima intensidade de luz e pleocroísmo que facilita a sua separação pela manipulação digital no software Photoshop. A seguir, a imagem é implementada a través do programa SPO (Shape Preferred Orientation) desenvolvido por Launeau e Robin (2003 - artigo no prelo) para o cálculo dos parâmetros da OPF da distribuição de grãos pelo método de interceptos ou do tensor de Inércia. Os dados escalares e direcionais da OPF em 2-D (elipses) são repassados ao programa ELLIPSOID.EXE (2003 - artigo no prelo) para o cálculo do elipsóide (3D) representativo da trama mineral da rocha.

\section{O Tensor de Inércia (2D)}

Um objeto isolado em uma imagem binária pode ser definido por um conjunto de pixels adjacentes contendo um mesmo código numérico (Fig. 3). A forma de um objeto 2D é, na maioria das vezes, anisotrópica e mais ou menos convexa. Esta forma poderá ser atribuida a uma elipse, se ela não se afasta 
demasiadamente da figura convexa ideal. A elipse pode ser determinada pelo cálculo dos momentos de $2^{\mathrm{a}}$ ordem do tensor de inércia 2D (Rink, 1976).
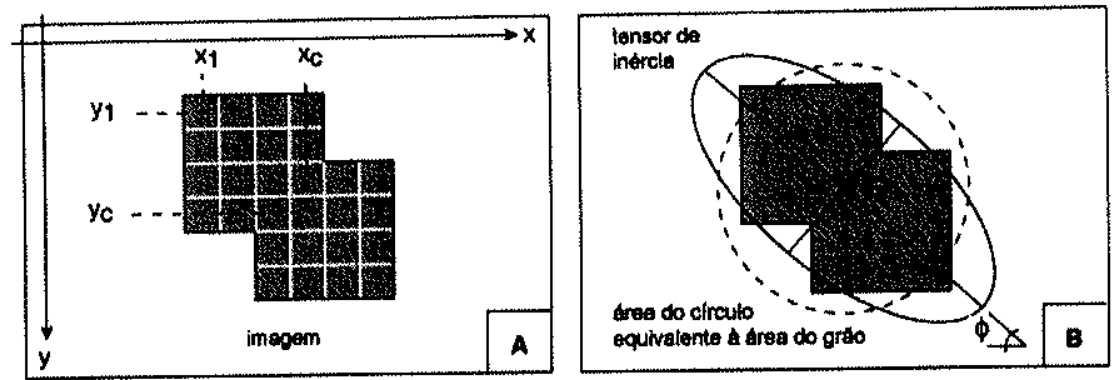

Figura 3. A) Conjunto de pixels adjacentes definindo um objeto (grão) e suas coordenadas no referencial xy ; B) Tensor de inércia do grão representado por uma elipse e orientação $(\phi)$ de seu eixo maior. $G$, centro de massa do objeto.

Cálculo da OPF em 2D: médias tensoriais e implicações

Do conjunto de grãos que constitui uma seção ( $x y, x z$ ou $y z$ ) é possivel determinar uma elipse média representativa da orientação preferencial $2 \mathrm{D}$ da população. $O$ cálculo da elipse média pode ser feito de quatro maneiras diferentes, a saber (Fig. 4):

(i) média tensorial do tensor de inércia (Fig. 4a): o tensor de inércia médio Mg é obtido pela média tensorial dos $n$ tensores de inércia 2D calculados para cada grão. Ao considerar a área de cada grão no cálculo da média, os grãos maiores terão um peso no cálculo do tensor. A elipse $G$ resultante dependerá da quantidade e orientação dos grãos maiores que constituem a população.

(ii) média tensorial do tensor normalizado (Fig. 4b): o tensor médio normalizado Mn é obtido pela média tensorial dos $n$ tensores de inércia 2D normalizados pela área de cada grão. A elipse $\mathrm{N}$ resultante independe do tamanho dos grãos, porém depende de suas razões axiais.

(iii) média tensorial da equação da elipse (E) (Fig. 4c): neste caso a elipse média é obtida pela média tensorial $\mathrm{Mp}$ das $n$ equações quadráticas das elipses (Shimamoto e Ikeda 1976). Esta solução corresponde ao cálculo inverso de (i), visto que a elipse média é determinada utilizando-se o inverso dos eixos principais a e b. Obtem-se assim uma elipse $P$ que depende do tamanho dos grãos, como em (i), porém com peso maior nos grãos menores da população. 
O significado e implicaçōes destes diferentes modos de representação da fábrica é ilustrado na figura 4. As elipses G (Fig. 4a) e P (Fig. 4c), que dependem do tamanho e anisotropia dos grãos individuais, realçam a fábrica dada pelos grãos grandes e pequenos, respectivamente. A elipse N (Fig. 4b), que depende unicamente da anistropia dos grãos individuais, corresponde à direção mediana dos grãos grandes e pequenos que constituem a população. A elipse D (Fig. 4d), que independe do tamanho e anisotropia dos grãos, pode ser utilizada para verificar a uniformidade das orientações da população e avaliar a existência de sub-populações.
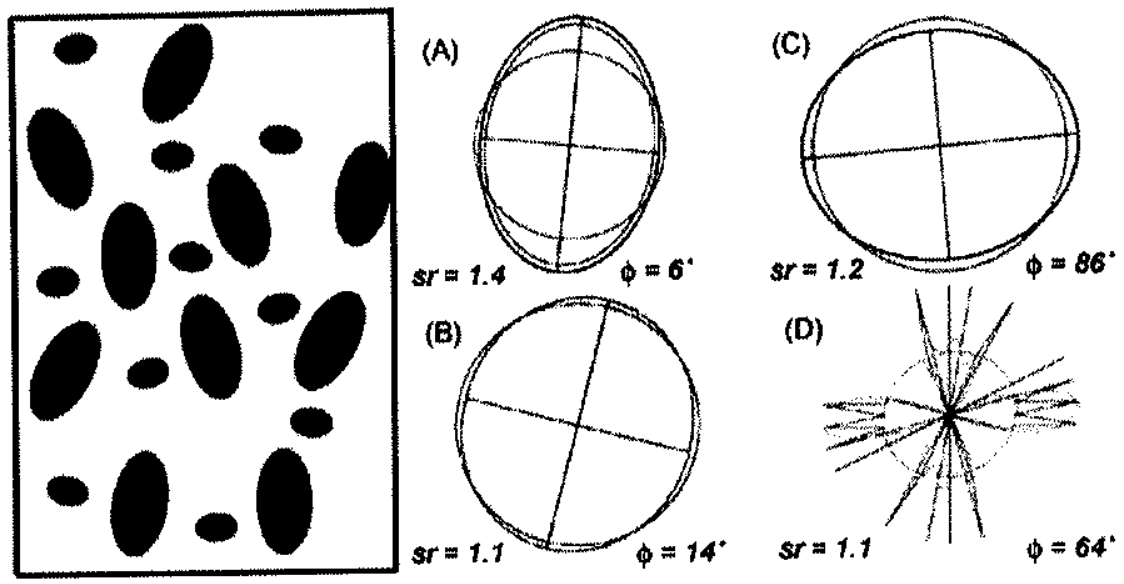

Figura 4. Caso simples de elipses com populações distintas com orientação média $\mathrm{N}$ $S(s r=a / b=2)$ e $E-W(s r=1.5)$. (A) Elipse $G$, com peso maior nos grãos grandes; $(B)$ Elipse $N$, ou normalizada; (C) Elipse $P$, com peso maior nos grãos pequenos e, (D) Elipse $D$, correspondendo a dispersão medida pelos cossenos diretores do eixo maior de cada tensor. sr, anisotropia da elipse média, $\Phi$ é o ângulo entre 0 eixo maior da elipse e o referencial vertical.

\section{O método de interceptos}

Quando os grãos que formam uma população não podem, ou não devem ser separados, é utilizado o Método de Interceptos para calcular a anisotropia do agregado (Saltikov 1958, Underwood 1970 em Launeau e Robin 1996). Os princípios da técnica são sumariamente resumidos na figura 5. Ela é baseada na contagem de interceptos que uma linha qualquer percorrendo a imagem que cruza a fase de interesse (Fig. 5a). Para um ponto $x$ na grade reticulada de coordenadas $(i, j)$, ou então um pixel na imagem bitmap, o número de interceptos é igual a 1 se o ponto $x$ pertence a fase, ou zero se ele não pertence. Este procedimento é feito ao longo de uma série de linhas de análise 
paralelas entre si, que rotacionam sucessivamente a um ângulo $\alpha$ previamente estabelecido.
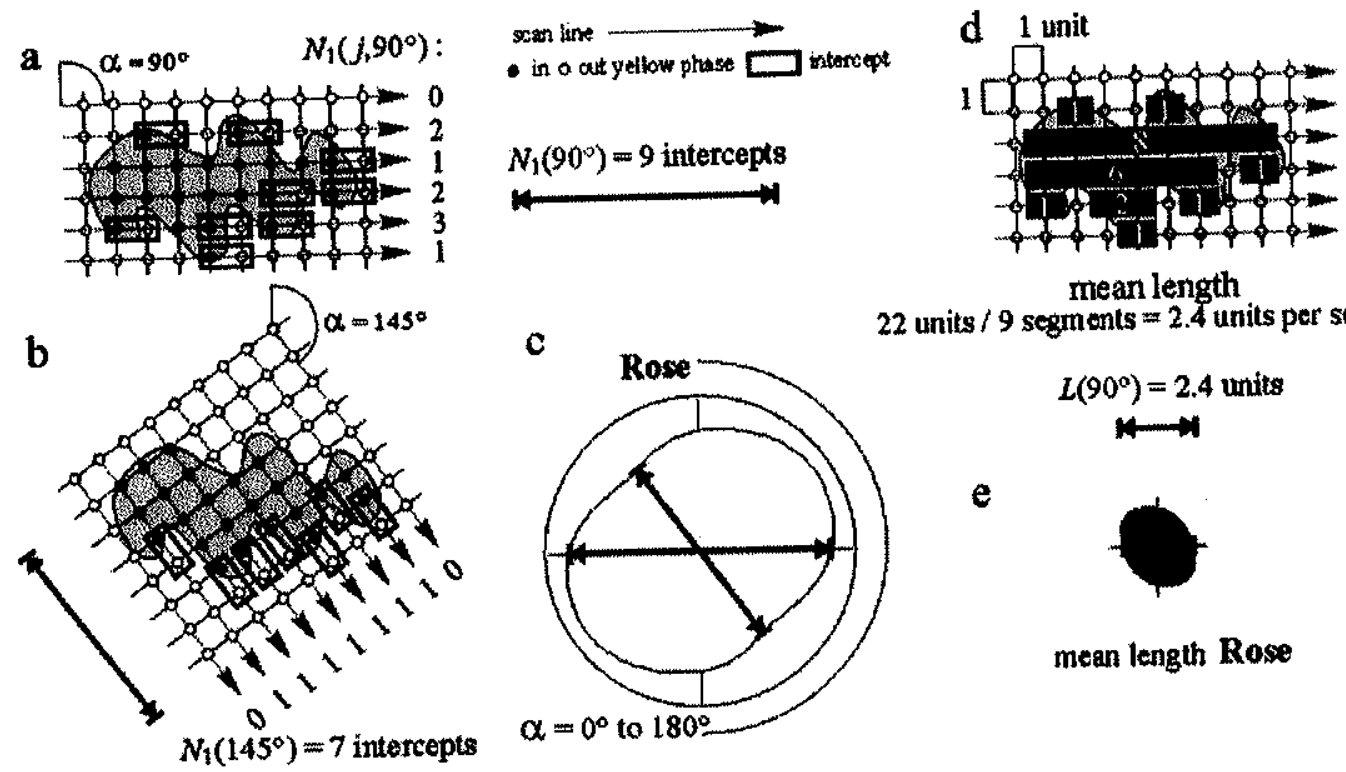

mean length

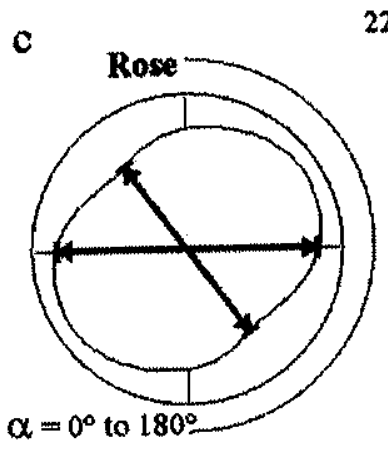

22 units $/ 9$ segments $=2.4$ units per segment

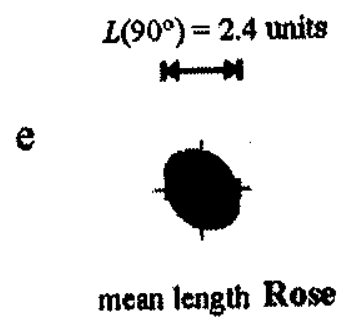

Figura 5. Método de interceptos. a) grade reticulada de análise a $90^{\circ}$ e contagem de 9 interceptos decorrentes de 9 saídas do grăo (fase); b) grade reticulada de análise a $145^{\circ}$ e contagem de 7 interceptos; c) rosa de contagem de interceptos - a contagem mínima indica a direção de alongamento; d) cálculo dos segmentos atravessados pela grade a $90^{\circ}$ (superficie dividida pela contagem de interceptos); e) rosa de comprimento médio.

Determinação da OPF 3D: método do tensor quadrático de forma

O método foi introduzido na geologia estrutural por Shimamoto e lkeda (1976), com a finalidade de reconstituir o elipsóide (3-D) conhecendo a magnitude e orientação de três elipses representativas de planos mutuamente ortogonais. $O$ método foi modificado por Launeau e Cruden (1998) e recentemente generalizado para seções não-ortogonais por Robin (2002).

Um mínimo de três seções adequadamente distribuidas é necessário para que a solução elipsoidal seja encontrada. $O$ índice de incompatibilidade $\sqrt{F}$ permite checar a convergência das seções, onde valores $<10 \%$ indicam a convergência dos resultados para um elipsóide, caso contrario $(\sqrt{F}>15 \%)$, os dados convergem para um hiperbolóide e 0 resultado não tem significado 
estrutural. Este parâmetro é dado no programa para cada seção e permite, eventualmente, subtrair a seção ou sub-populações fortemente incompativeis.

Os parâmetros do elipsóide 3-D podem ser relacionados aos parâmetros de Jelinek (1981) que descrevem a forma do elipsóide de anisotropia de suscetibilidade magnética, onde $\mathrm{P}^{\prime}$ é o grau de anisotropia corrigido e T a forma do elipsóide $(>0$, oblato, $<0$ prolato, onde $T$ varia de 1 a -1$)$. Se os eixos do elipsóide são $b_{1} \geq b_{2} \geq b_{3}$ (respectivamente $A, B \in C$ ),

$$
\begin{gathered}
P^{\prime}=\exp \left[2\left(l_{1}^{2}+l_{2}^{2}+l_{3}^{2}\right)\right]^{1 / 2}, \operatorname{com} l_{n}=\ln \left(b_{n} / b_{B} \text { e } b_{B}=\left(b_{1}, b_{2}, b_{3}\right) / 3\right. \\
T=\left[2\left(\ln b_{2}-\ln b_{3}\right) /\left(\ln b_{1}-\ln b_{3}\right)\right]-1 \\
\mathrm{~T}=1 \operatorname{se} A=B>C, \mathrm{~T}=0 \operatorname{se} A>B>C, \text { e } \mathrm{T}=-1 \operatorname{se} A>B=C .
\end{gathered}
$$

Quatro tipos de elipsóides (G, N, P, D e I), correspondendo aos métodos de determinação da distribuição de grãos, são obtidos no programa ELLIPSOID.EXE. Dependendo do grau de homogeneidade da população em 2-D, é possivel extrair aleatoriamente várias sub-populações de modo a testar a reprodutibilidade do elipsóide em diferentes partes da imagem. $O$ número de elipsóides combinados é dado por $n^{s}$, onde $n$ é o número sub-imagens (= subpopulação) e $s$ o número de seções. Se $s=3$ (seções $x y, x z$ e yz da amostra), - número de elipsóides recombinados depende da quantidade de imagens $n$ extraídas da seção. Se $n=1$ ( 1 imagem por seção), teremos 1 elipsóide; se $n$ $=2$, serão 8 elipsóides, e assim sucessivamente. 


\section{RESULTADOS E DISCUSSÃO}

\subsection{COMPLEXO METAMÓRFICO DE EL ORO}

\subsubsection{Geologia Regional}

Nos Andes de Huancabamba, que corresponde à zona de transição entre os Andes Centrais e os Andes do Norte, aparece o denominado terreno AmotapeTahuin, interpretado como um microcontinente (Mégard, 1987; Mourier, 1988) e mais recentemente como correlacionável com a Cordilheira Real (Aspden et al., 1995), denominado $\mathrm{CM}$ de El Oro (encarte 2). O complexo metamórfico compreende rochas metamórficas de baixo até alto grau com um trend estrutural E-W, anômalo com respeito ao trend regional andino NNW da Cordilheira Real. Para o NW, o complexo está coberto por depósitos não consolidados do Terciário Superior e Quaternário da planície costeira. O seu limite norte é definido pela falha Jubones de direção E-W. Para leste e sul, o limite está definido por um complexo vulcano plutônico terciário e por sedimentos cretácicos da bacia de Alamor (encarte 2).

As rochas que compreendem a zona de estudo no CM de El Oro são:

(1) uma seqüencia semipelítica levemente ou não metamorfizada denominada unidade El Tigre;

(2) uma seqüência semipelítica com metamorfismo variável da unidade La Victoria, interpretada como o equivalente de alto grau norte da unidade $\mathrm{El}$ Tigre. Estas seqüências são consideradas como de idade de deposição paleozóica, provavelmente de idade devoniana (Feininger, 1982) e até permiana (Martinez, 1970), com metamorfismo Permiano e granitogênese Triássica. Os metassedimentos da Unidade La Victoria são xistos micáceos com eventual granada, aparecem crenulados e intercalados com meta-arenitos com sericita. Ocasionalmente, apresentam migmatização que junto à presença de granada e sillimanita, sugerem condições de médio a alto grau de metamorfismo. A abundância de andaluzita, ausência de cianita e restrição da granada nas áreas de metamorfismo de mais alto grau, indica condições de metamorfismo de baixa pressão para sequencia metamórfica do CM de El Oro (Feininger, 1982);

(3) as rochas da unidade La Bocana que incluem um número de diferentes litologias não diferenciadas principalmente granitóides foliados, migmatitos, paragnaisses e em menor quantidade xistos anfibólicos intercalados, 
(4) os plutões de La Florida, Marcabelí e El Prado, associados com gnaisses de alto grau e migmatitos. Estes corpos se dispõem em direção $E-W$ limitados por zonas de cisalhamento destral de direção E-W, e

(5) rochas do Complexo Máfico Piedras, que correspondem principalmente a metagabros e anfibolitos triássicos (encarte 2).

Os granitóides da unidade La Bocana aparecem no extremo norte da zona de estudo num cinturão $E-W$ intimamente relacionados e cartograficamente não diferenciados dos gnaisses e migmatitos regionais (encarte 2). $O$ contato dos granitóides de La Bocana com os anfibolitos ao norte da zona é falhado, marcado por zonas estreitas de milonitização tanto nos granitóides (Fig. 7 fotos $1,2,3$ ) quanto nos anfibolitos que adicionalmente apresentam estruturas elipsoidais. O contato entre as zonas gnáissicas ao norte com os xistos da Unidade La Victoria para sul é gradual e perfeitamente concordante. Apresentam textura granular grossa, aparecendo desde granitóides sem apreciável orientação mineral nem deformação, (evidenciada apenas pela formação de subgrãos e extinção ondulante em micas) até granitóides foliados, granitos gnáissicos e milonitos com $\mathrm{K}$ feldspato formando localmente estruturas augen. São comuns estruturas migmatíticas com abundante segregação de quartzo e formação de leucogranitos (Fig 7- fotos 10, 11). Eventualmente, ocorrem enclaves máficos centimétricos e estruturas shlieren. Apresentam desde textura granular grossa, sem apreciável orientação mineral nem deformação, apenas evidenciada pela formação de subgrãos em quartzo e extinção ondulosa nas micas até texturas gnáissicas definidas pelas micas e quartzo, as vezes o $\mathrm{K}$-feldspato forma estruturas augen. Composicionalmente, os granitóides de La Bocana correspondem a monzogranitos e granitóides ricos em quartzo (Fig. 6). A composição mineral destas rochas é plagioclásio entre $15-30 \%$; K-feldspato entre $20-25 \%$, formação de mirmekita ocasional; quartzo entre 30 e $55 \%$ (este último no caso dos leucosomas e com abundante K-feldspato); biotita entre 10 e $30 \%$ ligeiramente cloritizada; muscovita entre 0 e $10 \%$ e aparece aparentemente apenas nas zonas de maior deformação; granada entre $0-8 \%$ em porfiroblastos; sillimanita prismática entre $0-3 \%$ (localmente 10\%) acompanha a estrutura gnáissica; possivel cordierita em algumas amostras. Acessórios zircão, allanita, apatito.

O plutão de Marcabell aflora no centro da zona de estudo como um corpo alongado na direção SW-NE, concordante às estruturas regionais (encarte 2, fig. 17). $O$ corpo situa-se no limite entre os metassedimentos de baixo gra ao sul da unidade de El Tigre com os metassedimentos de médio grau da Unidade 


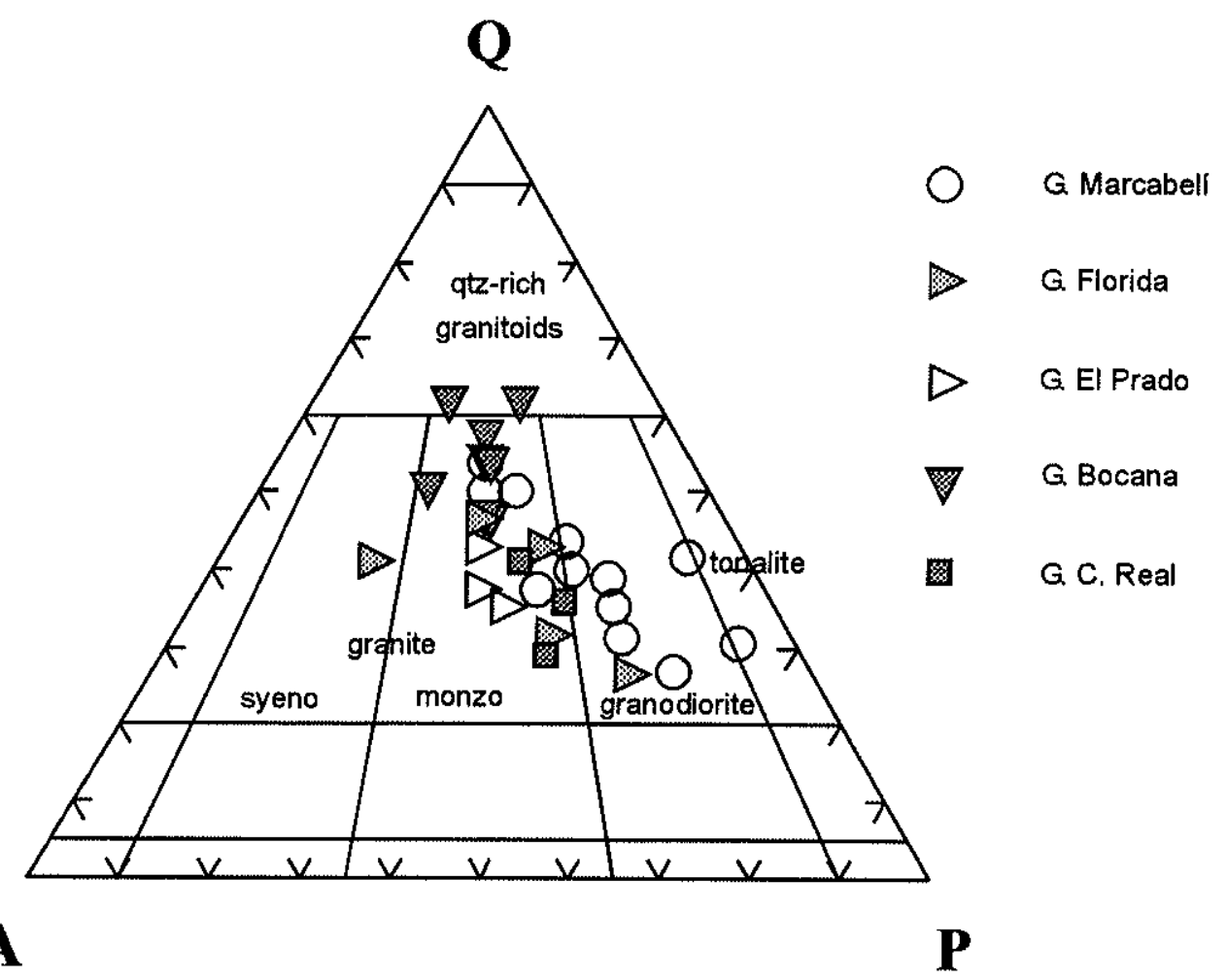

Figura. 6. QAP para as rochas do Complexo metamórfico de El Oro e Cordilheira Real do Equador. 
La Victoria ao norte. O contato norte do corpo é extremamente afetado pela deformação, com cunhas de metassedimento encaixado entre o granitóide milonitizado. O contato parece corresponder, nesta parte, a uma estrutura de direção regional N60E/45NW. Observam-se também contatos falhados e intrusivos na parte NE do corpo e assimilação de metassedimentos. Ocasionalmente, o contato do plutão de Marcabelí na sua parte sul está marcado por zonas de milonitos subparalelos à foliação metamórfica regional com indicadores de cisalhamento sistematicamente destrais. $O$ plutão de Marcabelí não corresponde a um corpo homogêneo, porém consta de fácies de granulometria média e aparência foliada na sua maior parte. No extremo leste da região sul do corpo, onde o plutão aparece com forma de cunha (encarte 2) aparecem amplos domínios com granulometria grossa e abundante K-feldspato, cuja relação com o corpo principal é incerta, podendo corresponder a zonas pegmatíticas das fases finais de colocação. No contato com os metassedimentos na sua borda SE, coincidentemente na zona de aparecimento da fácies grossa granular feldespática, aparecem abundantes silos com espessura variável entre 1 e 2 metros de espessura perfeitamente concordantes e o corpo intrusivo principal gera auréola de contato nos metassedimentos. É notável a presença de abundantes enclaves máficos centimétricos estirados e orientados paralelos à foliação e presença de estruturas shlieren. Aparecem ainda diques quartzosos cortando o granitóide, estes últimos dobrados sendo a foliação de plano axial aparentemente subparalela à foliação regional. Petrograficamente, o corpo é constituído principalmente de granodiorito, porém, na parte sul, predomina a composição tonalítica. A textura é granular grossa nas zonas magmáticas dominada por cristais euédricos de oligoclásio com núcleo normalmente alterado, KFeldspato forma texturas pertíticas (flame pertite), biotita bem formada por vezes dobrada e alterada ocasionalmente a clorita; quartzo recristalizado as vezes cominuido. Texturas miloníticas nas zonas de maior deformação são definidas por biotita e muscovita, ribbons de quartzo e ocasionalmente por sillimanita (Fig. 18). A rocha está constituida por plagioclásio (15-40\%); quartzo $(30-40 \%)$ e teores menores localmente; K-feldspato (5-20\%), alcançando localmente $30 \%$; a biotita varia entre $10-15 \%$, localmente atinge $25 \%$; a muscovita entre $0 \%$ nas zonas magmáticas até $15 \%$ nas zonas deformadas; anfibólio entre 0-5\% (localmente 10\%) alguns deles formados possivelmente a partir de piroxênio; a sillimanita ocorre ocasionalmente podendo chegar até $5 \%$, accesórios zircão, esfena, monazita, apatito. 
O plutão de El Prado aparece na mesma posição estrutural do plutão de Marcabelí. Seus contatos são falhados na borda norte, enquanto na borda sul os contatos são intrusivos (encarte 2). Sua textura é granular média a grossa, contendo minerais idiomórficos a subidiomórficos com pouca deformação. $\mathrm{Na}$ microscopia, a deformação é caracterizada pelas formação de subgrãos de quartzo e extinção ondulante em biotita ou ainda aparência levemente foliada em campo. Composicionalmente o corpo situa-se no campo dos monzogranitos, como também verificado no plutão de La Florida (Fig. 6). A composição mineral é quartzo (30-35\%); plagioclásio (25 An) (20-30\%); K feldspato (20-25\%), biotita (15-25\%) e ocasionalmente muscovita. O plutão de El Prado aparece intrudido por corpos básicos com idades U-Pb de $20 \mathrm{Ma}$.

O Plutão de La Florida ocorre a NW da zona de estudo, aflora como um corpo alongado e controlado pelas estruturas regionais (encarte 2). Aparece espacialmente relacionado aos granitóides, gnaisses e migmatitos de La Bocana e ocasionalmente apresentando contatos gradacionais (Fig. 7- foto 9), mas também se observa intrusivo (Fig 7- foto 10,15). Bolsões graníticos dentro dos migmatitos apresentam características texturais similares àquelas do plutão (Fig 7- foto 16). O granitóide de La Florida aparece cortado por diques pegmatíticos com turmalina e muscovita e apresenta enclaves do metassedimento (Fig 7 - foto 17), por vezes concordantes à foliação (Fig. 7foto14). O contato, portanto, parece corresponder a uma mistura entre intrusão e gradação, esta última evidenciada pela transição entre um leucosoma bem definido até o granitóide propriamente dito (Fig. 7-foto 10). É comum observar intercalação dos metassedimentos e gnaisses com pacotes de granitóide similares aos descritos para o plutão de La Florida. Petrograficamente, este corpo apresenta como característica notável a presença ubiqua de fenocristais de $\mathrm{K}$ feldspato que podem ir até $8 \mathrm{~cm}$ (Fig 7- foto 12). Apresenta textura granular grossa inequigranular com deformação observável em afloramento. Composicionalmente, situa-se num amplo campo, desde sienogranitos, monzogranitos e granodiorito (Fig. 6). Mineralogicamente está constituído por quartzo (20-35\%) com extinção ondulosa e formação de subgrãos; plagioclásio $(15-40 \%)$, K-feldspato $(15-35 \%)$ com abundantes texturas de exolução, biotita (10-20\%), muscovita (5-10\%), cordierita (?) e granada em baixas quantidades. Os acessórios mais comuns são zircão, allanita e apatita para todas as amostras e presença eventual de opacos.

Sheets graníticos de alguns metros até algumas dezenas de metros aparecem intercalados concordantemente com os metassedimentos, tanto da Unidade La 
Granitóide foliado, concordante regionalmente com a estrutura gnáissica. São observados indicadores cinemáticos de cisalhamento dextral em veios de quartzo. Córrego Primavera, perto do vilarejo La Bocana.
Foto 1

Idem.

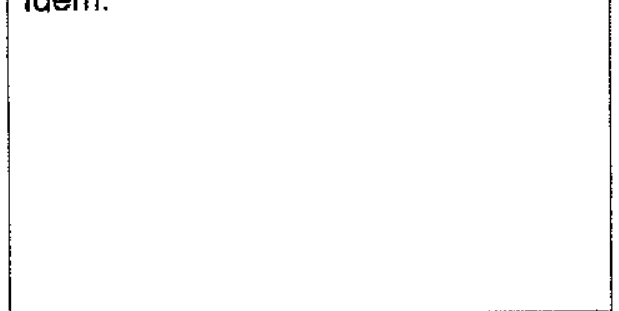

Foto 2

Indicadores cinemáticos de

Indicadores cinemáticos de cisalhamento destral em metapelitos indicados pela formação de porfiroclastos de quartzo formando estrutura S-C.Córreo Lajas, perto do vilarejo victoria. cisalhamento destral em metapelitos indicados pelas caudas asimétricas formadas por porfiroclastos de quartzo. Córrego Lajas, perto do o vilarejo Victoria.

Foto 4

Foto-3

Fragmentos de metassedimento assimilado $e$ alongado. Lente de quartzo alongado.

Córrego Primavera,

perto do vilarejo La Bocana. cisalhamento destral em metapelitos indicados por porfiroclastos com caldas asimétricas e formação de estruturas S-C. Córregolajas, perto do vilarejo Victoria

Foto 6

Indicadores cinemáticos de cisalhamento destral em metapelitos indicados por porfiroclastos com caldas asimétricas e formação de estruturas $\mathrm{S}-\mathrm{C}$ e bandas de cisalhamento. Córrego Lajas, perto do vilarejo Victoria
Indicadores cinemáticos de cisalhamento destral em metarenitos indicados por porfiroclastos de quartzo que a presentam caldas recristalizadas asimétricas. Córrego La Primavera, perto do vilarejo do mesmo nome.
Foto 7

Relação granitóide com os metassedimentos. O granitóide trunca as estruturas, mas aparece também conetado a veios de segregação no migmatito. perto do vilarejo La Bocana
Relação do granitóide de La Florida e os migmatitos regionais. Migmatitos assimilados no plutão, bolsões de leucogranito em continuidade com o plutăo. Córrego El Guineo, perto do vilarejo victoria.
Apariencia textural do plutão de La Florida. Geração de fenocristais de K-feldspato d e até $8 \quad \mathrm{~cm}$. Córrego El Guineo, perto do vilarejo Victoria.
Relação concordante do granitóide foliado com o metassedimento. Córrego La Primavera, perto do vilarejo La Bocana 


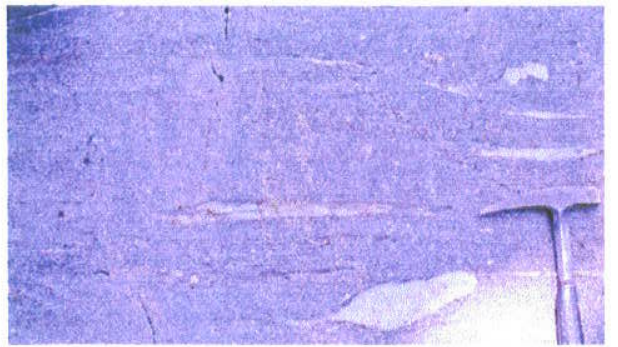

Foto 1

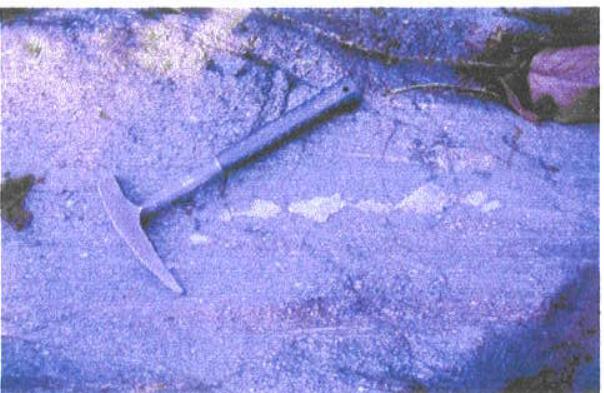

Foto 2

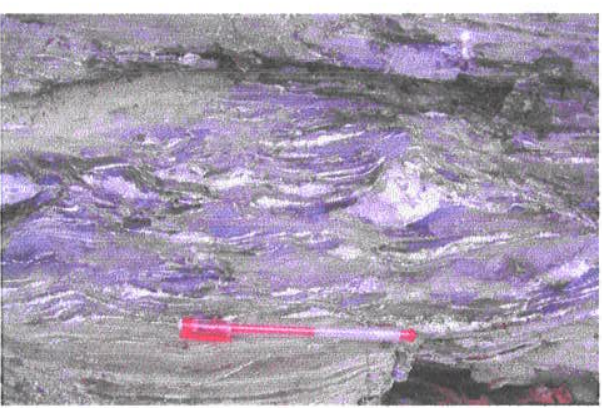

Foto 4
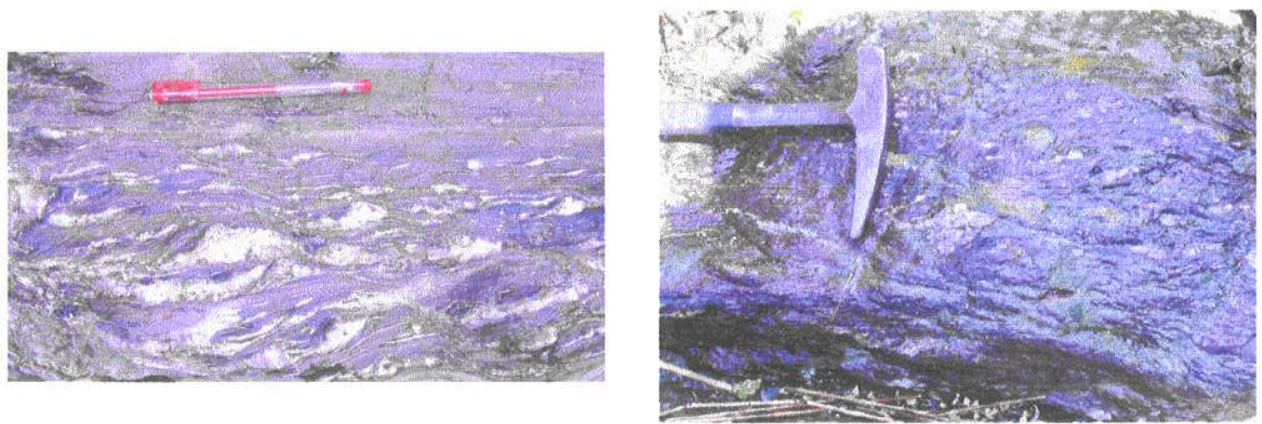

Foto 7
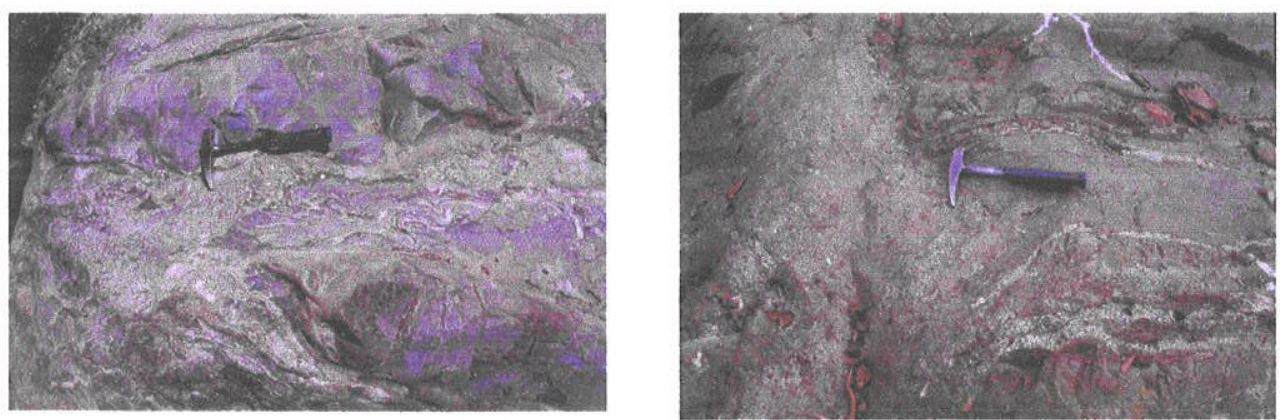

Foto 11

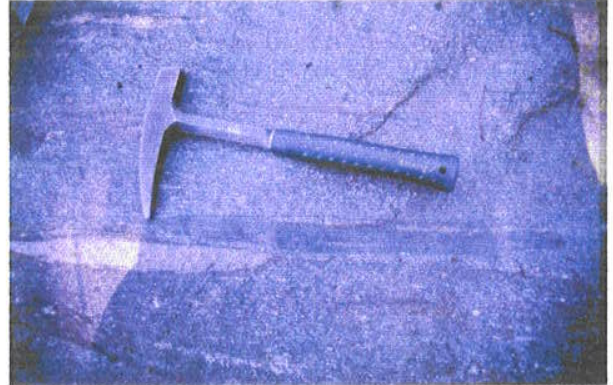

Foto-3

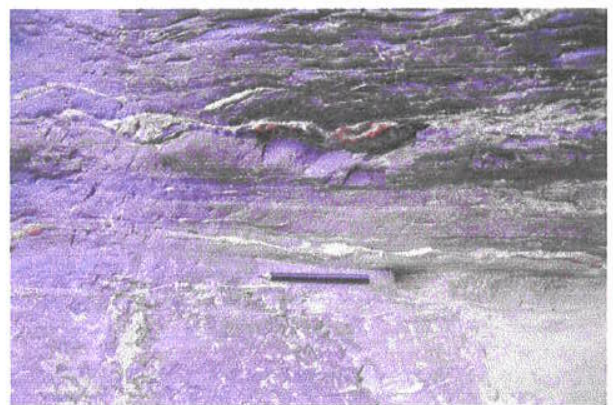

Foto 6

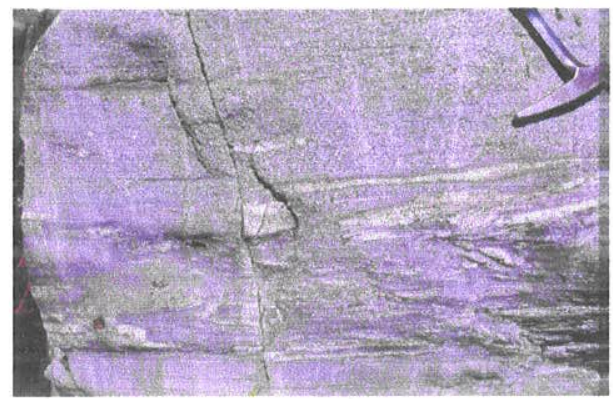

Foto 9

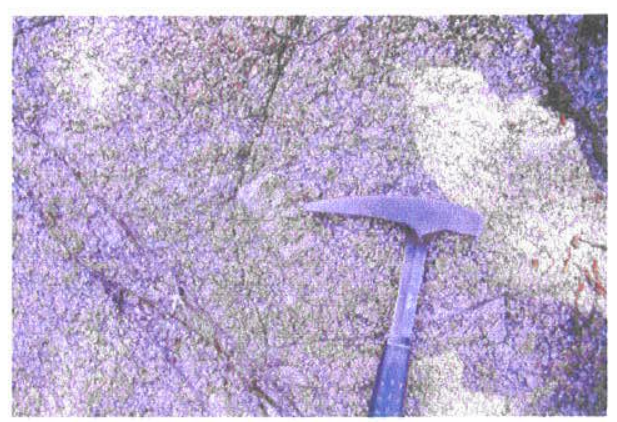

Foto 12

Figura 7. Indicadores cinemáticos de cisalhamento e relação dos granitóides com as encaixantes regionais. 
Pacotes de migmatito intercalados com metassedimento (paleosoma) básico (xistos anfibólicosamostra CVIN-84). Córrego Tahuin, perto do vilarejo Guayacán.
Assimilação de metassedimento aparentemente de forma concordante (foliação do granitóide ligeiramente observada). Córrego El Guarumo perto do vilarejo do mesmo nome.

Foto 14

Foto 13

Contato bem definido entre um granitóide e os

migmatitos. Córrego

El Guarumo, sul do

vilarejo do mesmo nome.

Foto 15

Bolsões de leucosoma de características texturais similares às do plutão de La Florida nos migmatitos. Assimilação de metassedimentos (paleosoma). Córrego Tahuin, perto de Guayacán.

Assimilados de metassedimentos (xenólitos) num leucosoma com caracteristicas texturais similares ao Plutão de La Florida. Córrego Tahuin, perto de Guayacán. 

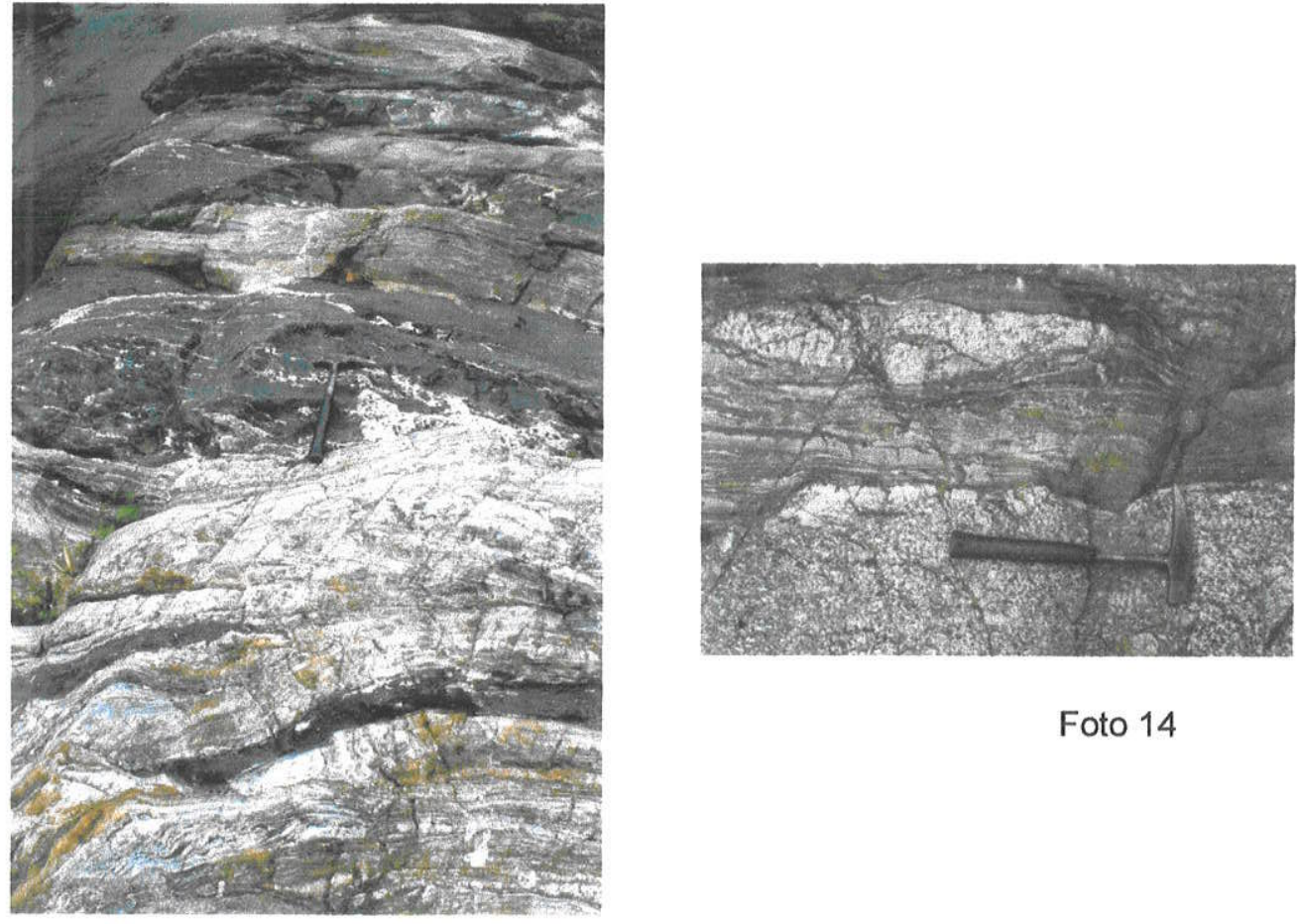

Foto 14

Foto 13
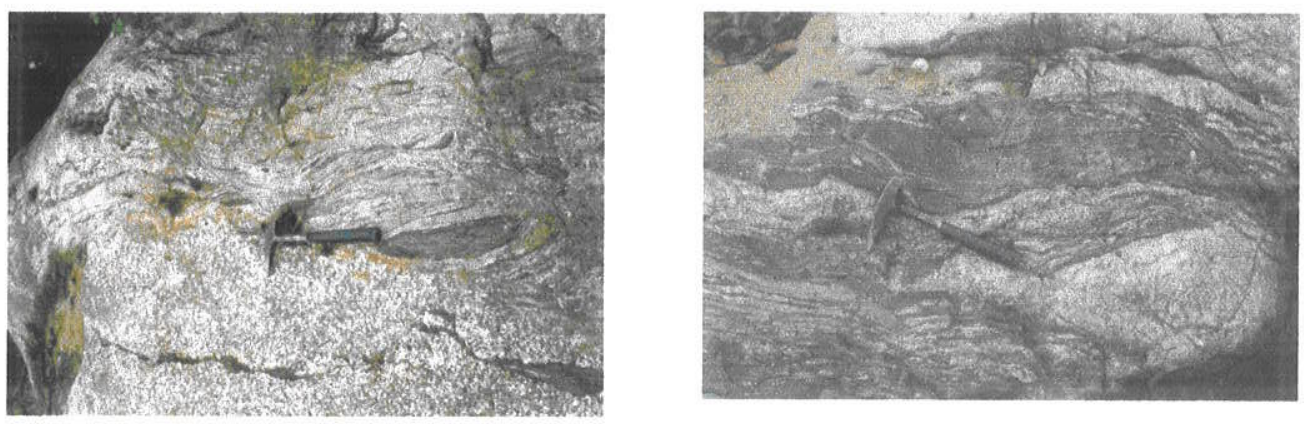

Foto 15

Foto 16

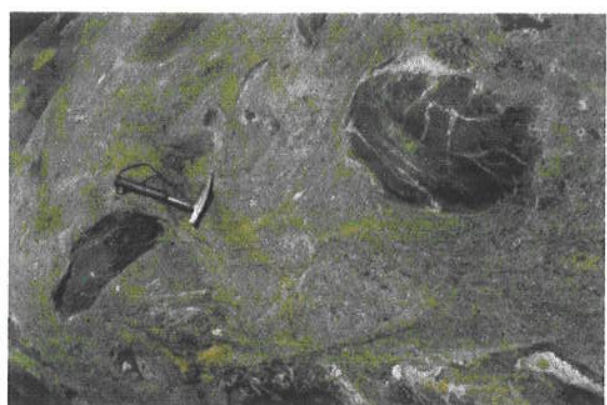

Foto 17

Figura 7b. Relação dos granitóides e migmatitos com as encaixantes regionais. 
Victoria, quanto com os metassedimentos de La Bocana. Estas massas graníticas têm provavelmente uma estreita relação genética com os granitóides descritos, mas é difícil relacioná-los diretamente com uns ou outros. Os corpos de granitóides intercalados e concordantes com os metassedimentos atingem larguras de até 100 metros e sua aparência em campo é similar ao granitóide de Marcabeli. Ocasionalmente, os corpos de granitóides aparecem truncando as estruturas embora apareçam também conectados a veios de segregação com tendência concordante (Fig. 7- fotos 9,10,11).

\subsubsection{Geoquímica de elementos maiores, traço e ETR.}

11 amostras de rochas granitóides do $\mathrm{CM}$ de El Oro foram analisadas para elementos maiores e traço e seis para ETR. São incluídas adicionalmente análises de elementos maiores para dois metassedimentos correspondentes às amostras analisadas isotopicamente (encarte 5).

Baseados em cálculos modais para 26 amostras (Fig. 6) e normativos para 11 amostras, podem-se definir campos relativamente específicos: os granitóides do CM de El Oro. Os granitóides de Marcabelí aparecem no campo dos granodioritos, mas algumas amostras agrupam-se inteiramente no campo dos tonalitos. Os granitóides de La Florida e El Prado situam-se com tendência ao campo dos monzogranitos e granodioritos. Os granitóides de La Bocana colocam-se num campo bem definido entre os monzogranitos e os granitóides ricos em quartzo num campo relativamente bem definido.

Os elementos maiores, particularmente os diagramas de $\mathrm{SiO}_{2}$ vs. $\mathrm{Al}_{2} \mathrm{O}_{3}$ e $\mathrm{MgO}$, sugerem consistência razoável entre os diferentes granitóides, e não é observado um agrupamento das amostras, a exceção possivelmente dos granitóides de La Bocana, que aparecem com altos valores de $\mathrm{MgO}$, e os granitóides de La Florida que aparecem com altos valores de $\mathrm{CaO}$ (Fig. 8). Notam-se as baixas concentrações de $\mathrm{Na}_{2} \mathrm{O}$ para a grande maioria dos granitóides estudados, exceção clara do granitóide de Marcabeli com valor de $3.61 \%$.

Os valores do número de $\mathrm{Mg}$ são consideravelmente similares para os granitóides do $\mathrm{CM}$ de El Oro, com valores em média de 40 para o granitóide de Marcabelí, 41,5 para El Prado, 39,5 para La Bocana e um valor um pouco menor de 36 para o granitóide de La Florida (encarte 6). 

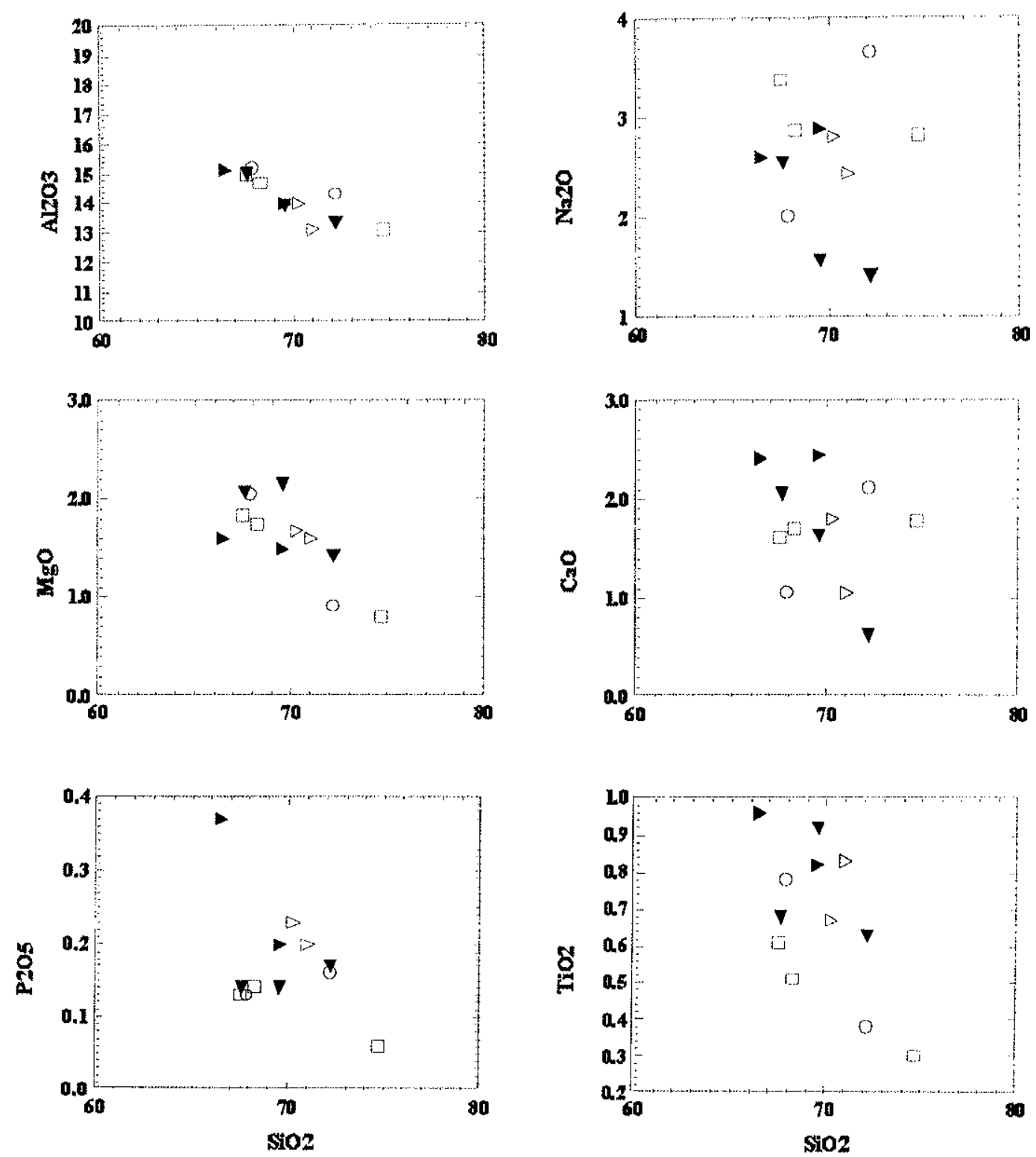

G.Mareabelí

- G.La Florita

D G.ElPrado

$\checkmark$ G.Bocana

G.C.Real

Figura 8. Diagramas de Harker para os granitóides do CM de EI Oro. Incluem-se 3 amostras da Cordilheira Real. 
O valor do Índice de saturação de alumínio (ASI) (Zen, 1986) de todas as amostras estudadas excede 1,1 (encarte 6), caracterizando os corpos como "granitos fortemente peraluminosos" (SPG) (Patiño-douce, 1999). Valores médios para ASI para as rochas estudadas são em geral maiores que os valores médios reportados para os granitos tipo $S$ de Lachlan fold belt na Austrália, com valores médios de 1,18 (Chapell e White, 1992). Os valores médios obtidos são: 1,42 para o plutão de Marcabelí, embora a presença de anfibólio, 1,28 para El Prado, 1,17 para La Florida sendo o valor mais baixo, e 1,73 para os granitóides de la Bocana. As amostras agrupam-se no campo de granitóides tipo $S$ do diagrama $\mathrm{Cao}$ vs $\mathrm{FeO}(\mathrm{T})$ e apresentam valores normativos de coríndon > 1\% (Chapell e White, 2001).

De acordo com o diagrama $\mathrm{K}_{2} \mathrm{O}-\mathrm{SiO}_{2}$ de Ricwood (1989), as amostras situamse principalmente no campo cálcio alcalino de alto $\mathrm{K}$ e uma parte menor das amostras no campo cálcio alcalino numa distribuição estreita das amostras.

O variograma obtido para as rochas do $\mathrm{CM}$ de El Oro apresenta um comportamento notavelmente similar entre elas e com fracionamento suave. Os padröes observados caracterizam-se pela forte anomalia negativa de $\mathrm{P}$ e anomalias negativas menores de $\mathrm{Nb}$ e $\mathrm{Sr}$ (Fig. 9). O comportamento dos elementos traço, portanto, sugere uma similitude estreita na composição nas rochas do $\mathrm{CM}$. O diagrama dos ETR apresenta algumas diferenças principalmente no relativo ao conteúdo total. As amostras exibem um fracionamento similar com notável anomalia negativa de Eu, porém, as amostras do granitóide de Marcabelí apresentam valores consistentemente mais baixos para todas as ETRs e muito similares aos valores das rochas da Cordilheira Real (Fig. 9b).

\subsubsection{Geologia Isotópica}

Foi determinada a composição isotópica de $\mathrm{Nd}$ e $\mathrm{Sr}$ para 11 amostras de rochas granitóides do $\mathrm{CM}$ de El Oro utilizadas também para a análise de elementos maiores e traço. $O$ encarte 5 apresenta os resultados obtidos para 9 granitóides do complexo metamórfico, incluindo as razões iniciais de $\mathrm{Sr}$, bem como os $\varepsilon_{s r}, \varepsilon_{N d(0, t)} \in$ as idades modelo. São incluídas também duas análises efetuadas para metassedimentos estreitamente relacionados com os corpos intrusivos e que poderiam representar as rochas fonte regionais. $O$ objetivo deste estudo é caracterizar as fontes e natureza dos protolitos dos corpos magmáticos em estudo. 

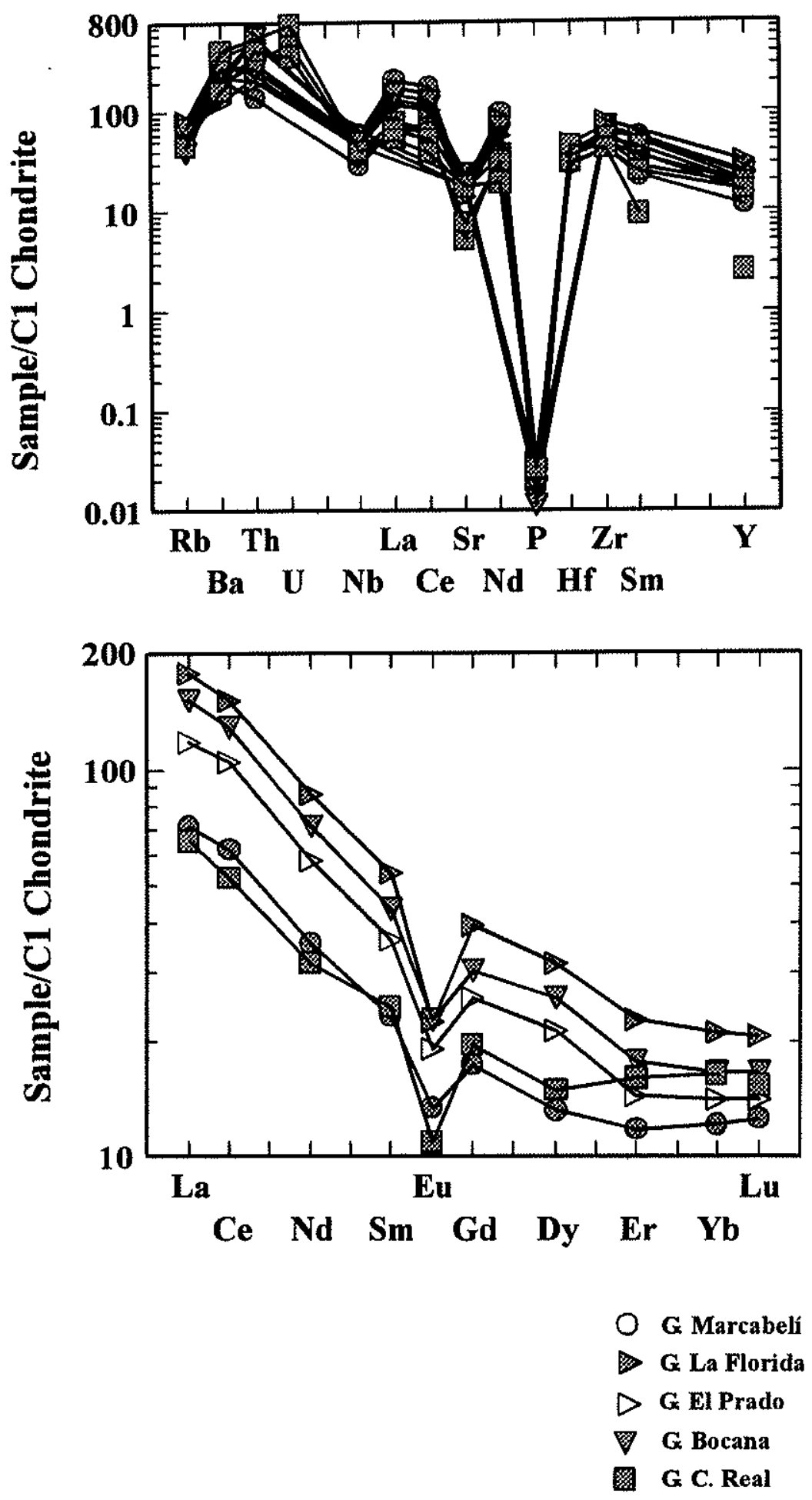

Figura 9. (a) Variograma de rochas para os granitóides do Complexo Metamórfico de El Oro e Cordilheira Real do Equador

(b) Padrões normalizados com os condritos para os conteúdos de REE para os mesmos grupos acima. 
As razões iniciais de $\mathrm{Sr}^{87} / \mathrm{Sr}^{86}$ calculadas para uma idade de $230 \mathrm{Ma}$ são relativamente elevadas, variando para os granitóides entre 0,708 e $0,720 \mathrm{com}$ uma média de 0,713 , mostrando uma importante heterogeneidade nos valores iniciais de $\mathrm{Sr}^{87} / \mathrm{Sr}^{86}$, refletindo a complexa natureza dos protolitos destas rochas. É possivel que estas diferenças sejam o resultado de uma incompleta homogeneização das fontes crustais, ou ainda contaminação variável com as rochas encaixantes. Os metassedimentos da unidade La Victoria apresentam um valor um pouco mais elevado de 0,725 e os metassedimentos básicos de la Bocana, que aparecem em forma restrita na região, apresentam um valor de 0,708 , o valor mais baixo encontrado para as rochas da região, e portanto, não podem ser considerados como materiais fonte na formação dos granitóides.

Os valores de $\varepsilon_{(\mathrm{Nd}, \text { t) }}$ para os granitóides apresentam uma variação entre -9.5 até -3.8 . Na figura $10 \mathrm{a}$, de $\varepsilon_{(\mathrm{Nd})}$ vs. $\varepsilon_{(\mathrm{Sr})}$ calculados ao presente $\left.{ }_{(0}\right)$, as amostras graficam no quadrante IV, o seja de materiais provenientes fundamentalmente de fontes crustais. Dentro da distribuição das amostras, destaca-se uma amostra do plutão de Marcabeli, que aparece como $\circ \varepsilon_{\mathrm{Nd}}$ menos negativo e 0 $\varepsilon_{\mathrm{Sr}}$ mais baixo dentro dos granitóides considerados. De forma contrastante, a outra amostra do plutão de Marcabelí aparece no extremo oposto do diagrama, mas desta vez, a amostra corresponde a um material fortemente milonitizado, - que poderia sugerir que sua composição isotópica foi modificada. As amostras correspondentes aos plutões de El Prado e La Florida, agrupam-se num campo intermediário, com valores de $\mathrm{Nd}$ um pouco mais negativos que os apresentados pelo plutão de Marcabeli e com razão de $\mathrm{Sr}$ inicial maior. Os granitóides de la Bocana aparecem com os valores de $\varepsilon_{\mathrm{Nd}}$ mais negativos e com valores similares de razões de Sr que os plutões de La Florida e El Prado. Além disso, localizam-se inteiramente dentro do campo das rochas do denominado Colorado front Range que representam a crosta continental superior paleoproteroizóica (DePaolo, 1981).

Os valores obtidos para os metassedimentos situam-se em campos extremos dentro do diagrama. Os metassedimentos anfibólicos de la Bocana, aparecem com $\varepsilon_{\mathrm{Nd}}$ ligeiramente positivo e com a menor razão de $\mathrm{Sr}$ inicial. Esta rocha é provavelmente constituída por material vulcano-sedimentar depositado na bacia de sedimentação. O metassedimento da unidade La Victoria, coloca-se no extremo de $\varepsilon_{\mathrm{Nd}}$ mais negativo e as razões iniciais de $\mathrm{Sr}$ mais altas.

Foram calculadas curvas de mistura entre dois materiais extremos segundo as equações apresentadas por DePaolo (1988). A álgebra que descreve a 
composição isotópica de misturas simples tem sido discutida por diferentes autores (Vollmer, 1976; Langmuir et al., 1978; DePaolo e Wasserburg, 1979 em DePaolo, 1988). Os modelos simples de mistura de materiais são diretamente aplicáveis a qualquer processo que envolva mistura mecânica de materiais (DePaolo, 1988). A distribuição das amostras no diagrama $\varepsilon_{(\mathbb{N a})} v s \varepsilon_{(\mathrm{Sr})}$ não pode ser explicada por simples mistura entre os metassedimentos ou entre o metassedimento da unidade La Victoria com as rochas de arcos vulcânicos modernos, representados pelos basaltos continentais de Columbia River (Columbia River basalts) (Carlson et al., $1981 \mathrm{em}$ DePaolo, 1988). A distribuição das amostras no gráfico poderia ser melhor explicada por heterogeneidade dos materiais fonte na geração dos granitóides em estudo.

As linhas de evolução de $\mathrm{Nd}$ são apresentadas na figura 10b. As idades modelo foram calculadas usando o modelo de evolução proposto por DePaolo (1991), no qual, o épsilon inicial da rocha é extrapolado até a curva de evolução do manto empobrecido (DM) ao longo de curvas de evolução crustal teóricas. As idades modelo, que normalmente representam idades de mistura para rochas crustais, são apresentadas no encarte 5 . As idades modelo variam entre 0,81 Ga para os metassedimentos anfibólicos de La Bocana e 1,84 Ga para os metassedimentos da unidade La Victoria, representando uma mistura de idades das rochas fonte, sendo que os metassedimentos anfibólicos receberam aporte de material juvenil neoproterozóico ou ainda mais jovem. Os granitóides do CM de El Oro apresentam idades intermediárias entre estes valores extremos, variando entre 1,33 Ga para o granitóide de Marcabelí, até 1,75 Ga para um granitóide de La Bocana. Pelas idades modelos e as curvas de evolução de $\mathrm{Nd}$ obtidas, pode-se inferir que o granitóide de Marcabelí aparece com características mais juvenis que os demais granitóides, fato observado também no diagrama $\varepsilon_{(\mathrm{Na})}$ vs $\varepsilon_{(\mathrm{S}) \text {.. }}$ É interessante notar que as amostras correspondentes ao plutão de El Prado envolvem as curvas obtidas para o plutão de La Florida, apresentando características mais evoluídas que $\circ$ granitóide de Marcabelí. Por fim, as curvas de evolução para os granitóides de la Bocana aparecem num campo inferior comparadas com os outros granitóides (Fig. 10b), mostrando um desenvolvimento mais evoluído para estas rochas. Os diagramas de $\varepsilon_{(\mathrm{Nd})} v s$. $\varepsilon_{(\mathrm{Sr})}$ e de curvas de evolução de $\mathrm{Nd}$ sugerem o aporte de material mais juvenil para o plutão de Marcabelí e o aporte de material crustal mais antigo para explicar a geração dos granitóides de La Bocana. Os granitóides de La Florida e de El Prado apresentam comportamentos intermediários. 

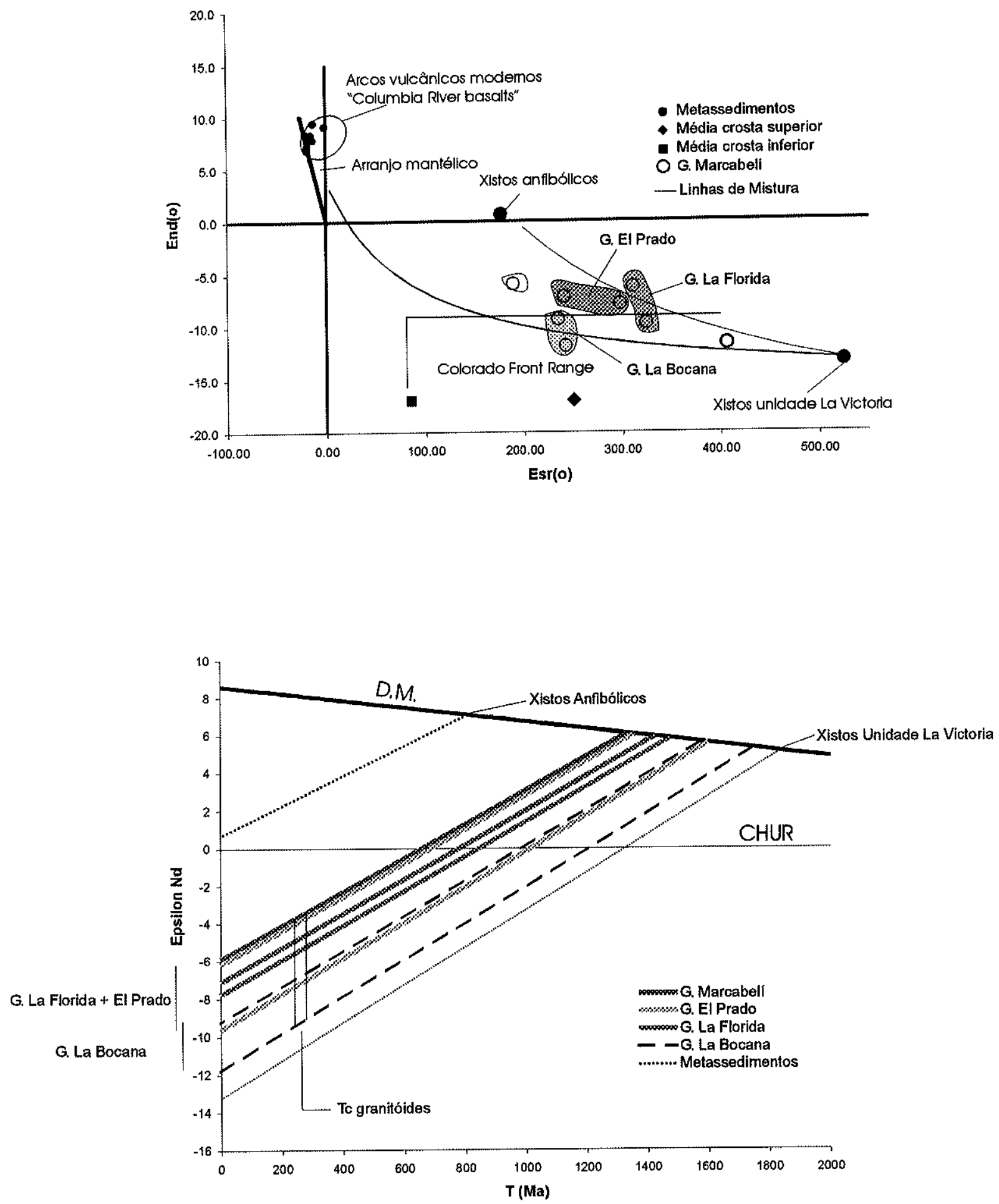

Figura 10. (a)Diagrama de correlação Epsilon Nd vs Epsilon Sr (hoje) (b) Curvas de evolução de $\mathrm{Nd}$ para as rochas do Complexo Metamórfico de El Oro, Equador. 
Em geral, os resultados do estudo isotópico e geoquímico dos granitóides do $\mathrm{CM}$ de El Oro sugerem derivação fundamentalmente crustal para os magmas parentais dos granitóides em estudo. $O$ papel de material mantélico na geração destes magmas é difícil de avaliar, mas as amostras que apresentam os valores menos negativos de $\varepsilon_{\mathrm{Nd}}$ e as menores razōes iniciais de $\mathrm{Sr}$ poderiam ter recebido contribuições deste tipo, como ocorre no plutão de Marcabeli, que adicionalmente apresenta uma porcentagem pequena de anfibólio.

\subsubsection{Geocronologia}

O estudo geocronológico efetuado na presente pesquisa para as rochas do denominado $\mathrm{CM}$ de El Oro compreendem uma serie de datações pelos métodos U-Pb SHRIMP em zircão e Ar-Ar em micas, tanto para os granitóides de Marcabeli, La Florida e os granitóides de la Bocana, quanto para as rochas metassedimentares do embasamento. Adicionalmente, foram obtidas idades Ar-Ar em micas para uma faixa milonítica do plutão de Marcabeli e idades ArAr em anfibólio para o Anfibolito de Piedras (encarte 2).

\section{Granitóide de Marcabeli}

O granitóide de Marcabelí apresenta zircões perfeitamente euédricos prismáticos, bem formados e com terminações piramidais. As imagens de $\mathrm{CL}$ permitem a observação de zonação oscilatória fina muito bem definida na maioria dos zircões e na totalidade dos zircões analisados (Fig. 11). A morfologia dos zircões, juntamente com a estrutura interna observada pelas imagens de $C L$, indicam um crescimento relativamente simples dos zircões com uma história geológica aparentemente não muito complexa, exceto pela observação de eventuais núcleos mal definidos que fazem parte de uma história anterior. As análises foram concentradas exclusivamente nas zonas de crescimento oscilatório, das quais as idades obtidas são interpretadas como de cristalização. As idades ${ }^{206} \mathrm{~Pb} /{ }^{238} \mathrm{U}$ são perfeitamente concordantes e apresentam um agrupamento principal com uma idade média ponderada de 234,9 $\pm 4,5$ Ma para 6 pontos (MSWD: 0,67; probabilidade de ajuste de 0,57), (Fig. 11) interpretada como a idade de cristalização do corpo. Uma única idade um pouco mais antiga de $269 \pm 4,5$ em zona de crescimento ondulatório pode ser um registro de atividade magmática precoce, similar a algumas idades obtidas para o plutão de La Florida (Fig. 12). Os conteúdos de $U$ e Th são relativamente homogêneos; o $U$ varia entre 145 e 347 ppm com média de 236 

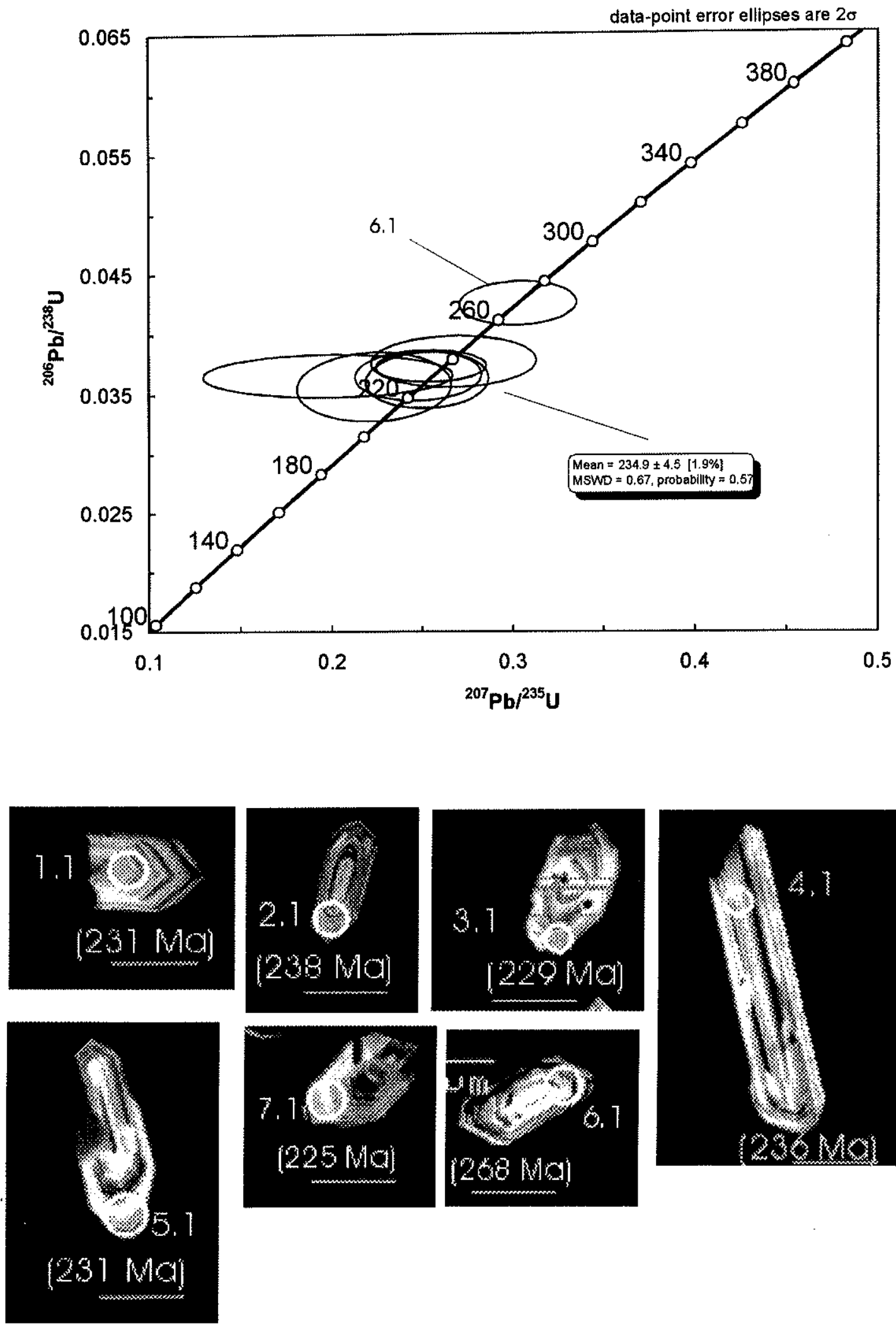

Figura 11. Granitóide de Marcabelí a. Diagrama Concordia

b. Imagens de Catodo-luminescência Tamanho da barra de escala 100 micras. 
ppm e o Th varia entre 56 e 174 ppm, com uma média de 89 ppm, fornecendo uma razão Th/ $U$ média de 0,37 , típicos de valores magmáticos (encarte 7 ).

Foram obtidas 4 datações pelo método Ar-Ar para o granitóide de Marcabelí, incluindo uma amostra de um milonito (CVIN 28). A amostra CVIN-05 foi coletada na parte SW do corpo onde predominam as texturas magmáticas; a amostra CVIN-20 foi tomada na parte meridional do corpo, onde predominam as texturas transicionais entre magmáticas e miloníticas e finalmente, a amostra CVIN-28 foi coletada na parte NE do corpo numa zona milonítica (Fig. 18). As implicações para a colocação do corpo são discutidas no capítulo sobre a estrutura e alojamento do Plutão de Marcabelí (cap. 4.1.5). Os resultados mostram formação de idades plateau muito bem definidas (Fig. 13a) de 229 \pm 1 Ma e 226,4 $\pm 0.6 \mathrm{Ma}$ para a zona de textura magmática, idades plateau um pouco mais jovens de $225,5 \pm 0.9 \mathrm{Ma}$ e $223,9 \pm 0.5 \mathrm{Ma}$ para a zona de textura transicional e idades plateau ainda um pouco mais jovens de $221 \pm 0.6$ e $221 \pm 0.4$ em muscovita e de $220 \pm 0.4$ e $221,3 \pm 0.5$ Ma em biotita para os milonitos. Esta distribuição aparente de idades parece ser reflexo da evolução da deformação num curto período de tempo e concomitante com a colocação do plutão. A idade média de resfriamento do plutão por baixo dos $300-350^{\circ} \mathrm{C}$ poderia corresponder às idades obtidas para as zonas com menor deformação com uma média de $227,1 \pm 1.2$ Ma e portanto a deformação foi desenvolvida num período de $6 \mathrm{Ma}$. Os resultados Ar-Ar são na média 7,8 Ma mais jovens do que os resultados $U-\mathrm{Pb}$, o que indica uma taxa de resfriamento muito rápida do corpo.

\section{O Granitóide de La Florida}

O granitóide de La Florida apresenta zircões euédricos, prismáticos, bem formados e com terminações piramidais. As imagens de $\mathrm{CL}$ permitem a observação de uma estrutura interna medianamente complexa, onde é notório o crescimento de zircão com zonação oscilatória bem definida a partir de núcleos antigos de diversa natureza, estes apresentando zonação oscilatória ou não (Fig. 12). Alguns dos sobrecrescimentos apresentam estrutura oscilatória irregular (acima do ponto 4,1 e 6,1; ponto 1,2; ponto 10,2) e recristalização (acima do ponto 9,1). As estruturas observadas favorecem uma história geológica mais complexa do que a observada para o plutão de Marcabeli. As análises obtidas foram tanto para as bordas quanto para os núcleos resultando um padrão complexo de distribuição de idades. A maior parte das análises aparece concordante (Fig. 12), com exceção da análise 3.1 

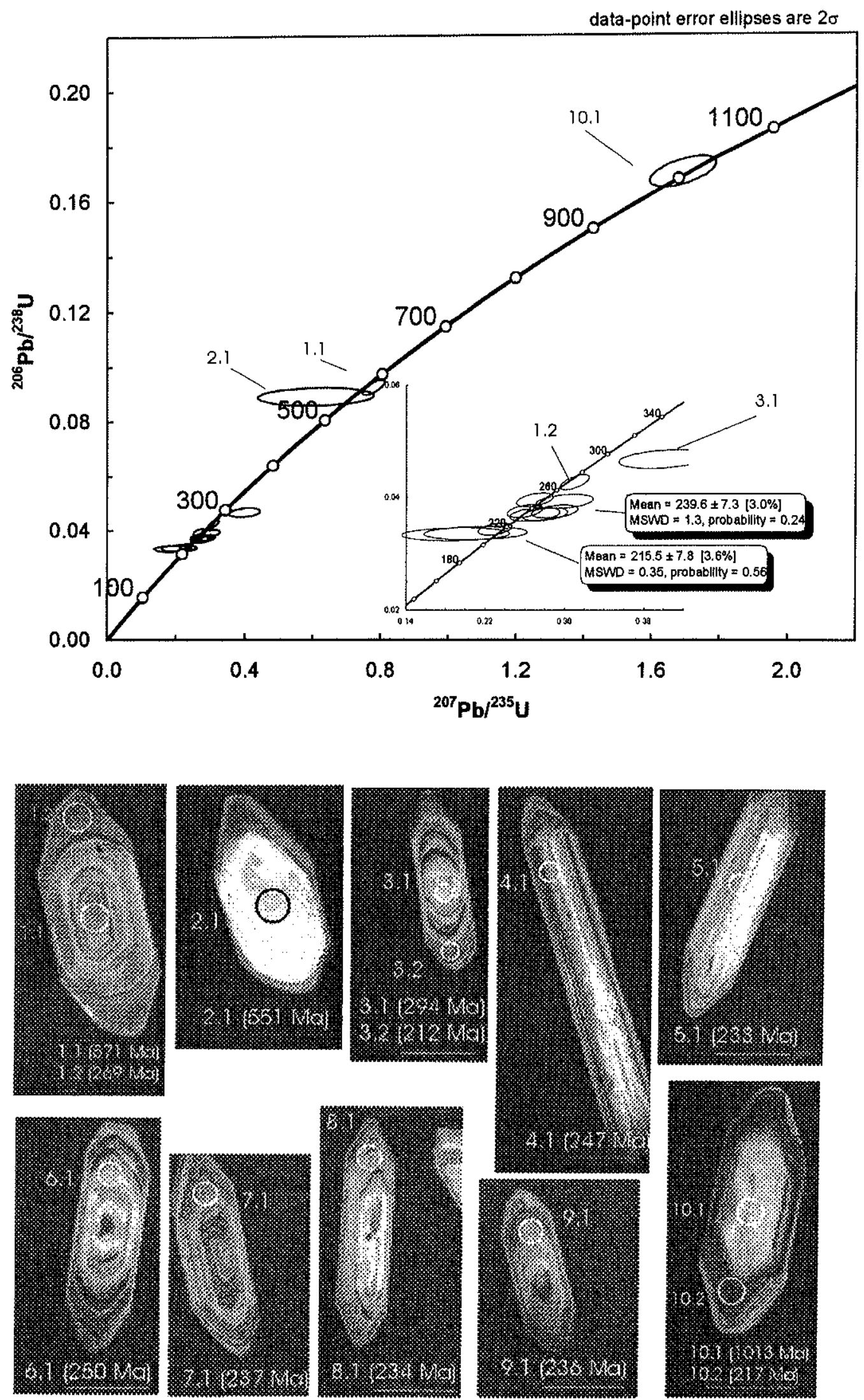

Figura 12. Granitóide de La Florida

a. Diagrama Concordia

b. Imagens de Catodo-luminescência

Tamanho da barra de escala 100 micras. 


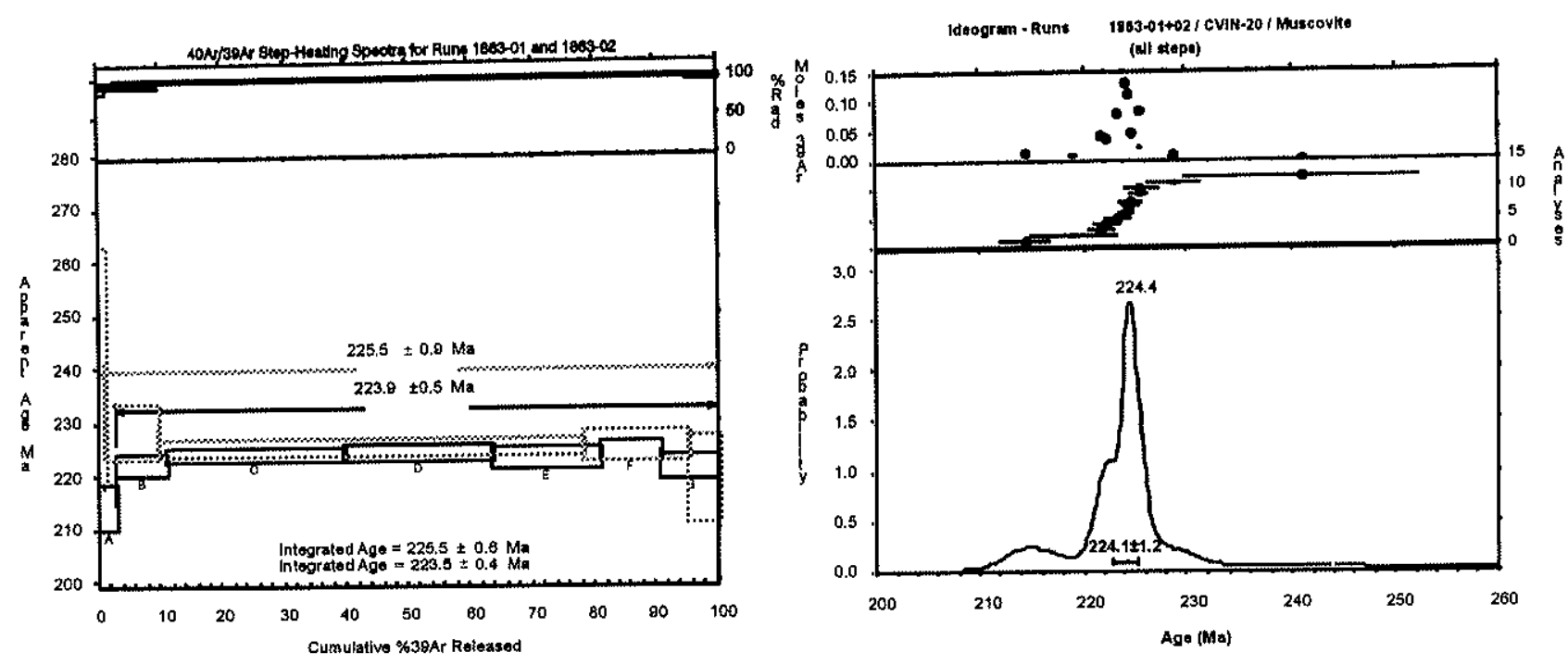

1864 / CVIN-05 / Blotte
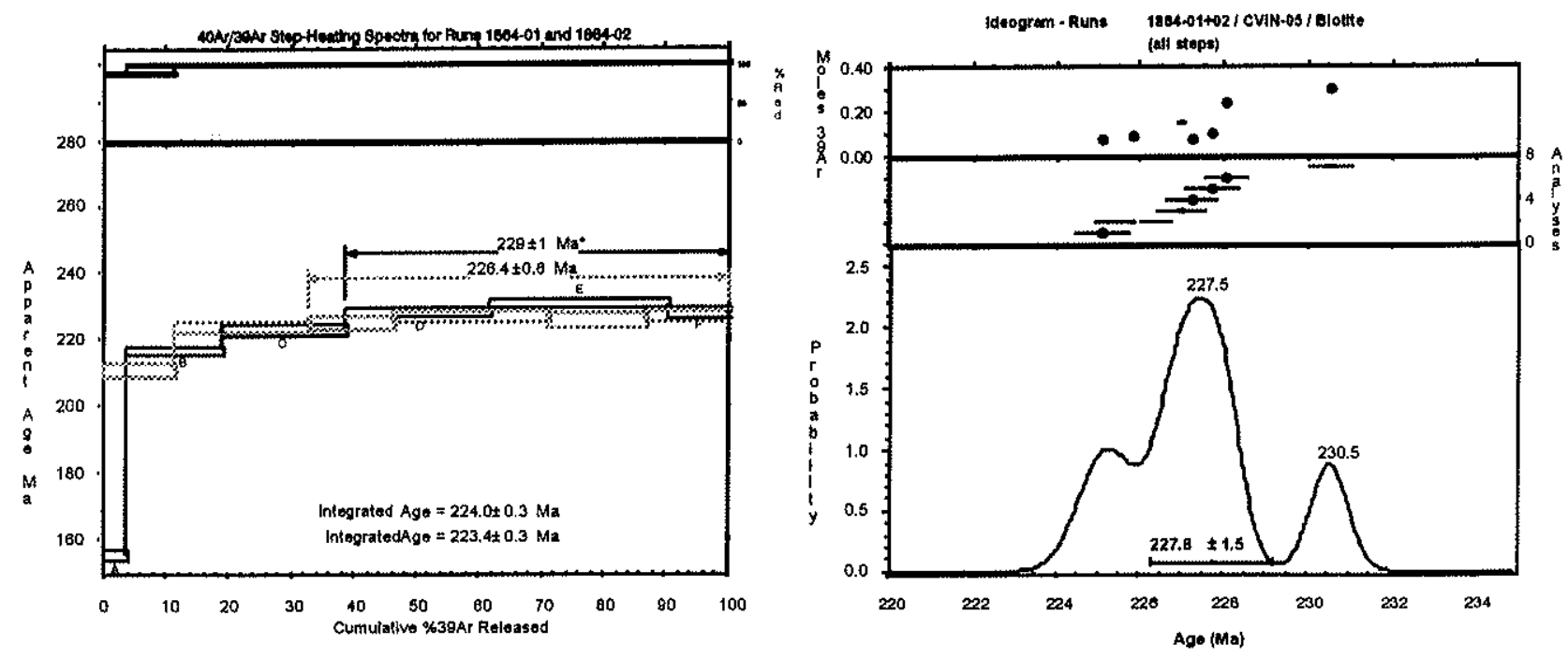

Figura 13 a. Plutäo de Marcabeli. CVIN-20 coletada na zona de transição; CVIN-05 coletada na zona magmática. 
1877 / CVIN-28 / Muscovite
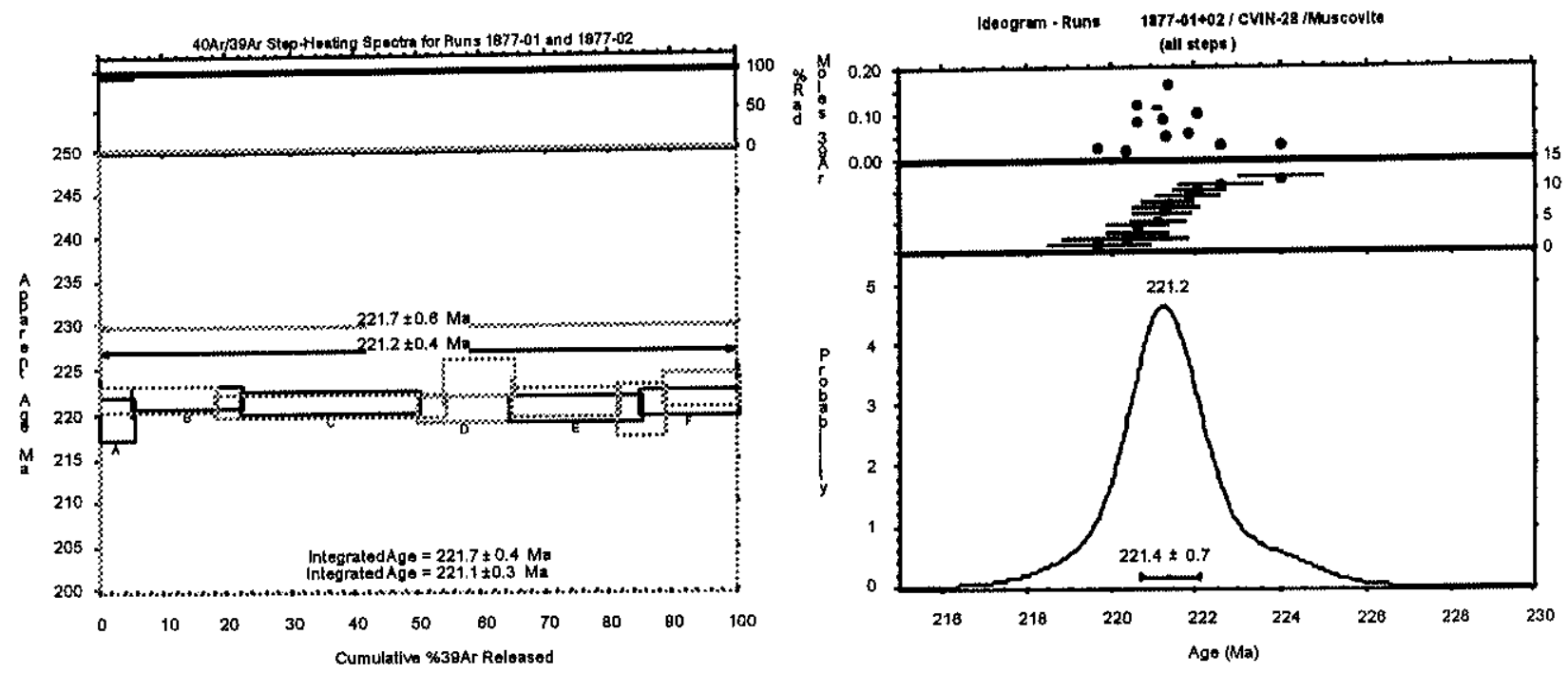

1893 / CVIN-28 / Blotite
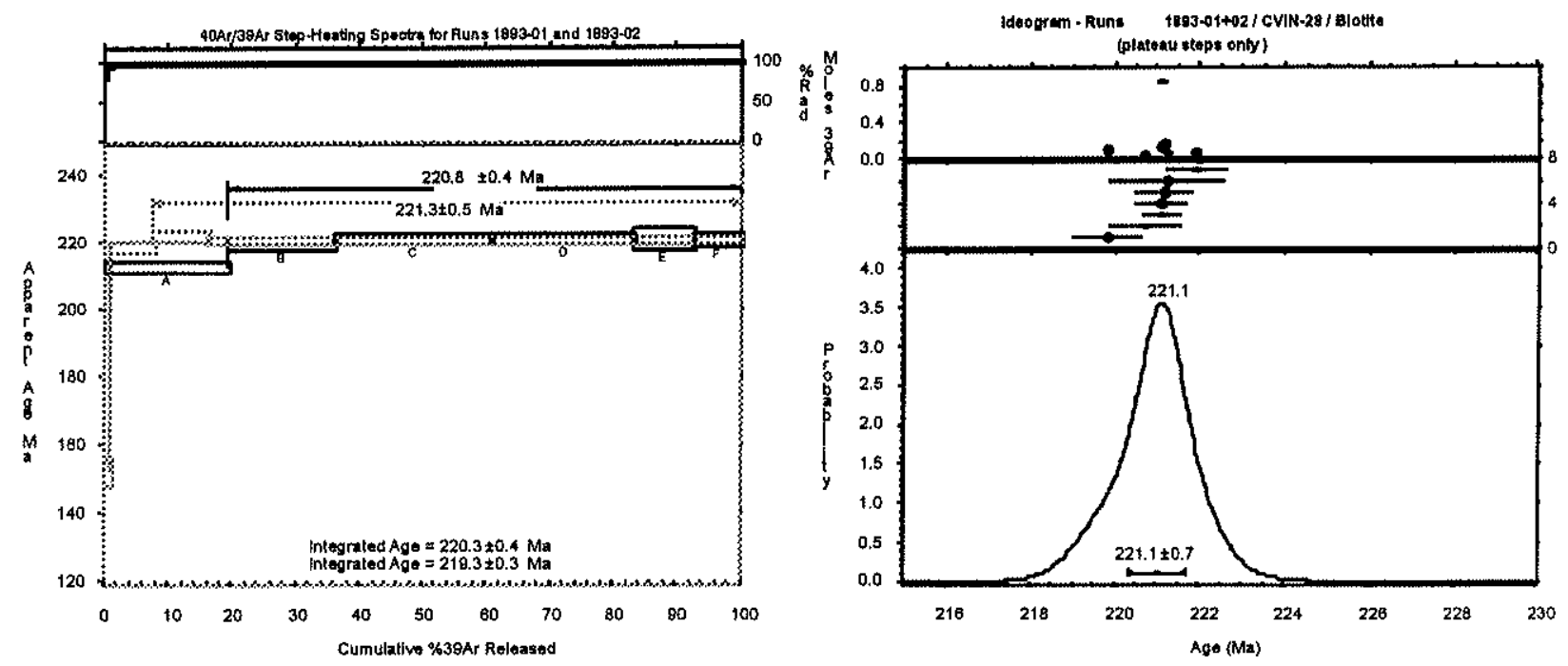

Figura 13 a. CONT. Plutão de Marcabelí. CVIN-28 coletada na zona de milonitização. 
1867 / CVIN-79 / Muscovite (P. La Florida)
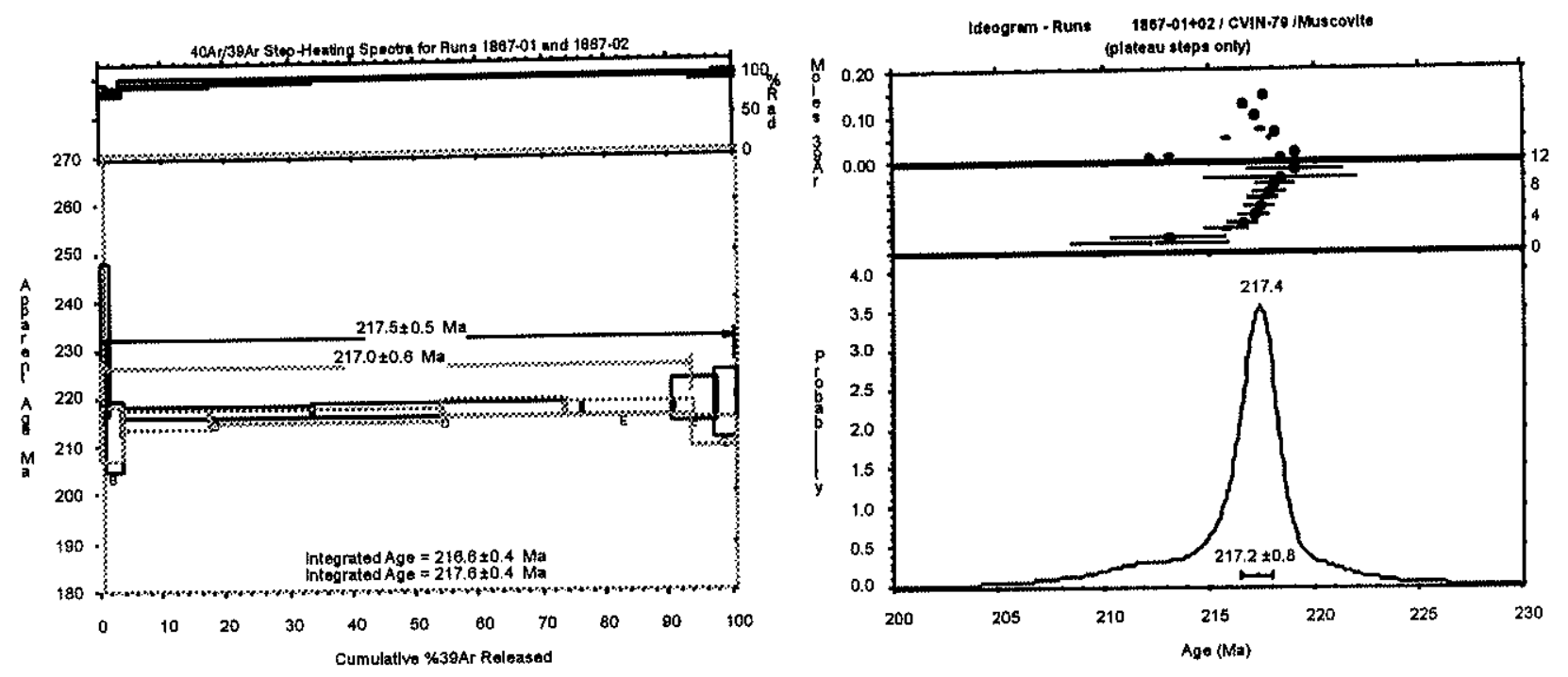

1866 / CVIN-39 / Biotte (P. Del Prado)
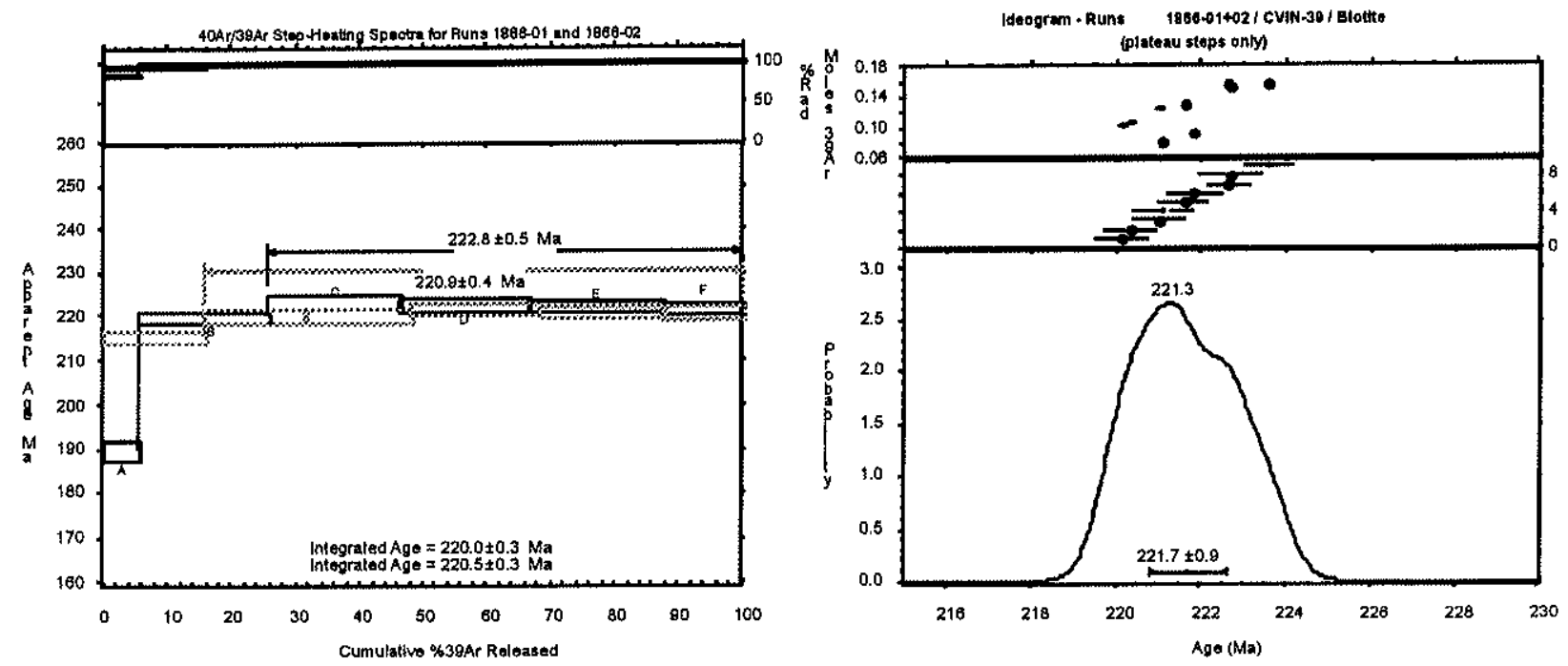

Figura13 b. Plutão de La Florida e El Prado. 
1869 / CVIN-85 / Muscovite

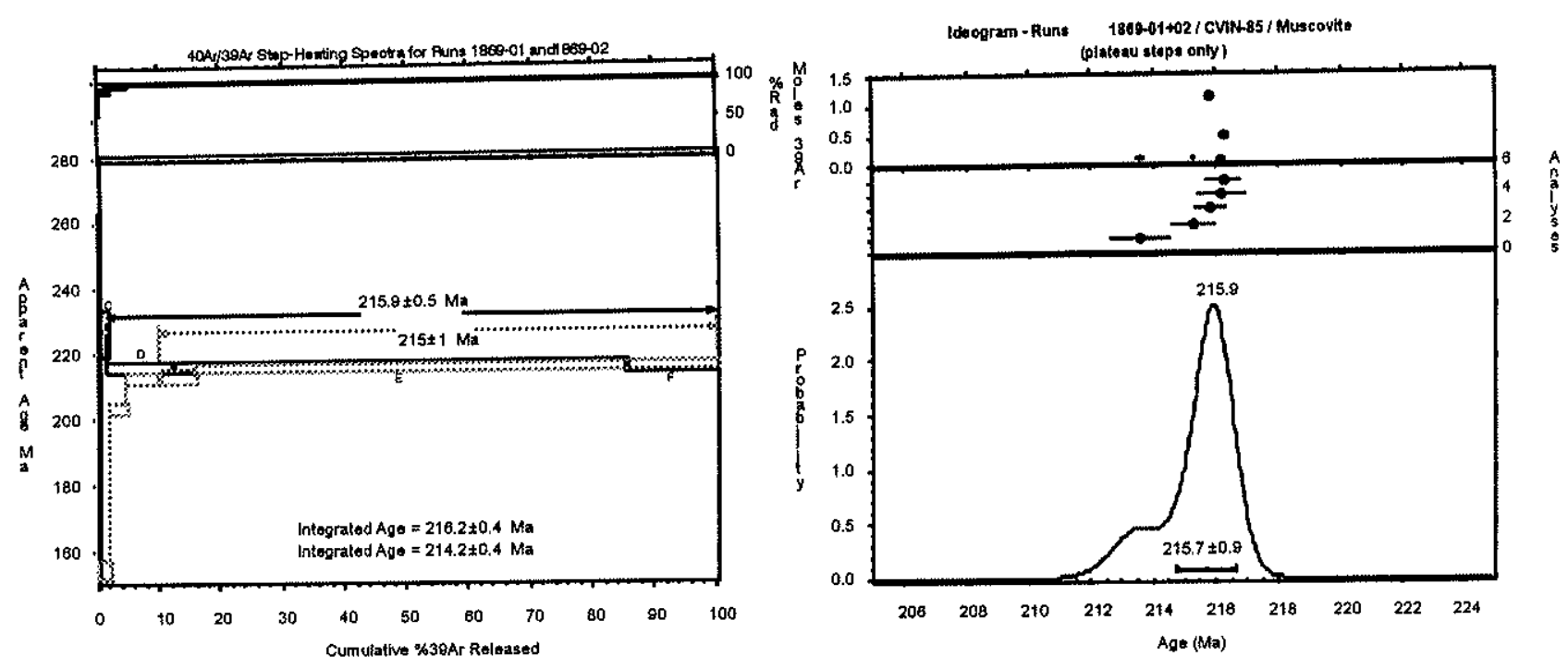

1872 / CVIN-83 / Muscovite
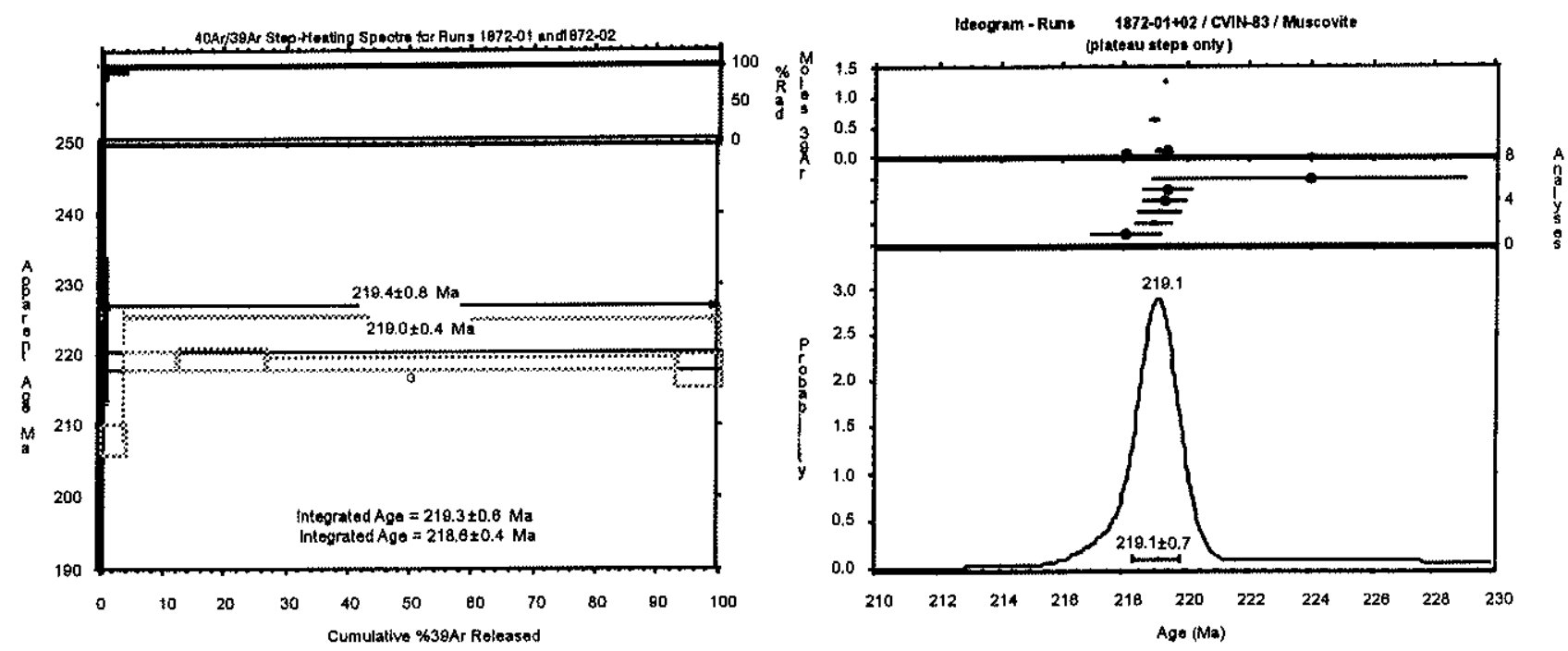

Figura 13 c. Granitóides de La Bocana. 
1873 / CVIN-60/Muscovite

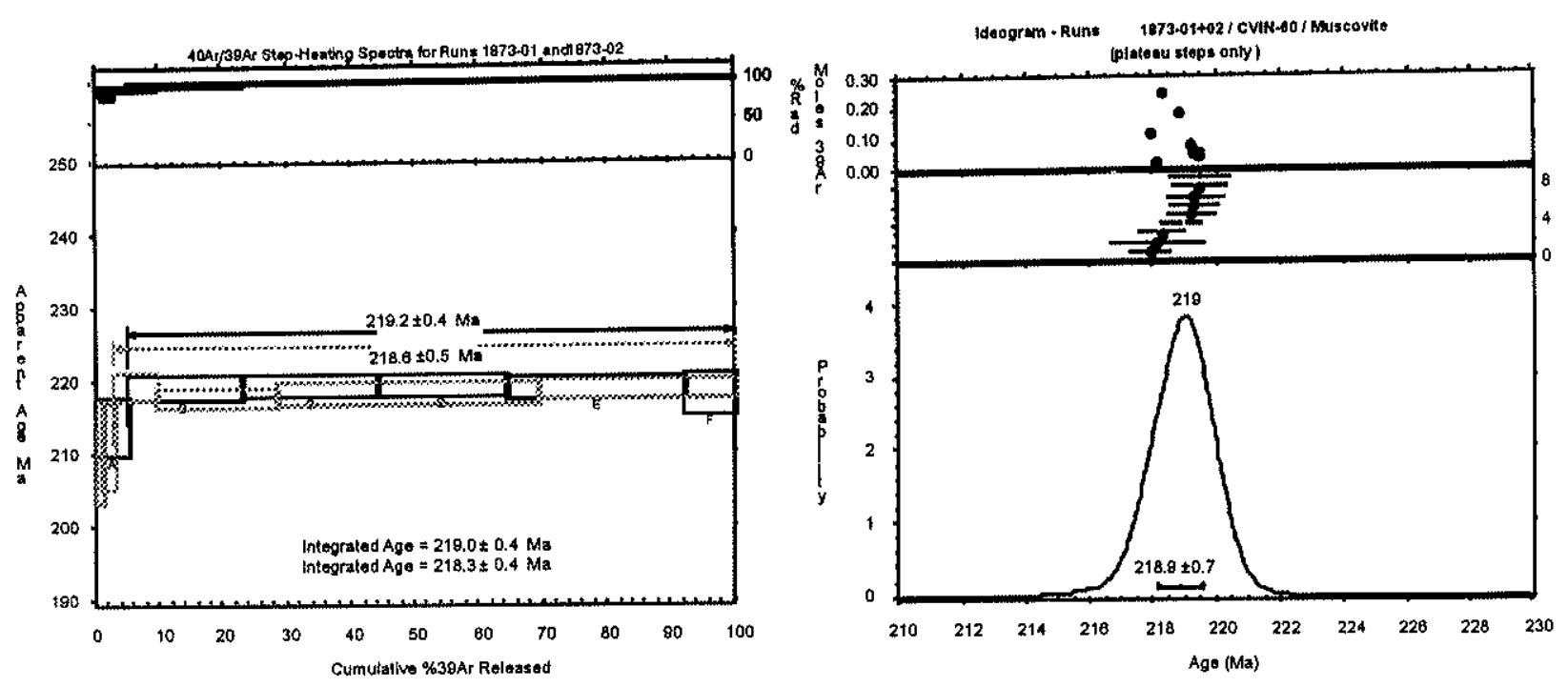

1885 / CVIN-56 / Blotite
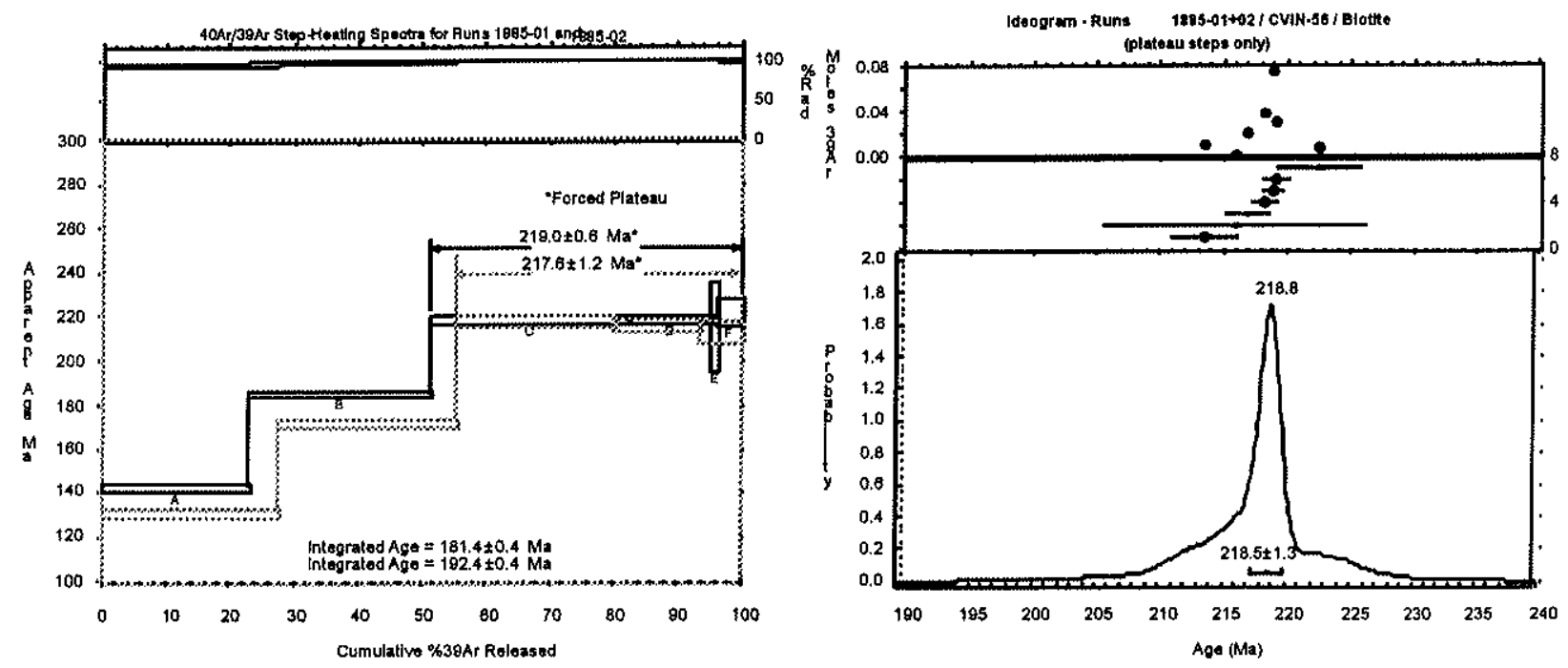

Figura 13 c. CONT. Granitóides de La Bocana. 
1874 / CVIN-62 / Biotte
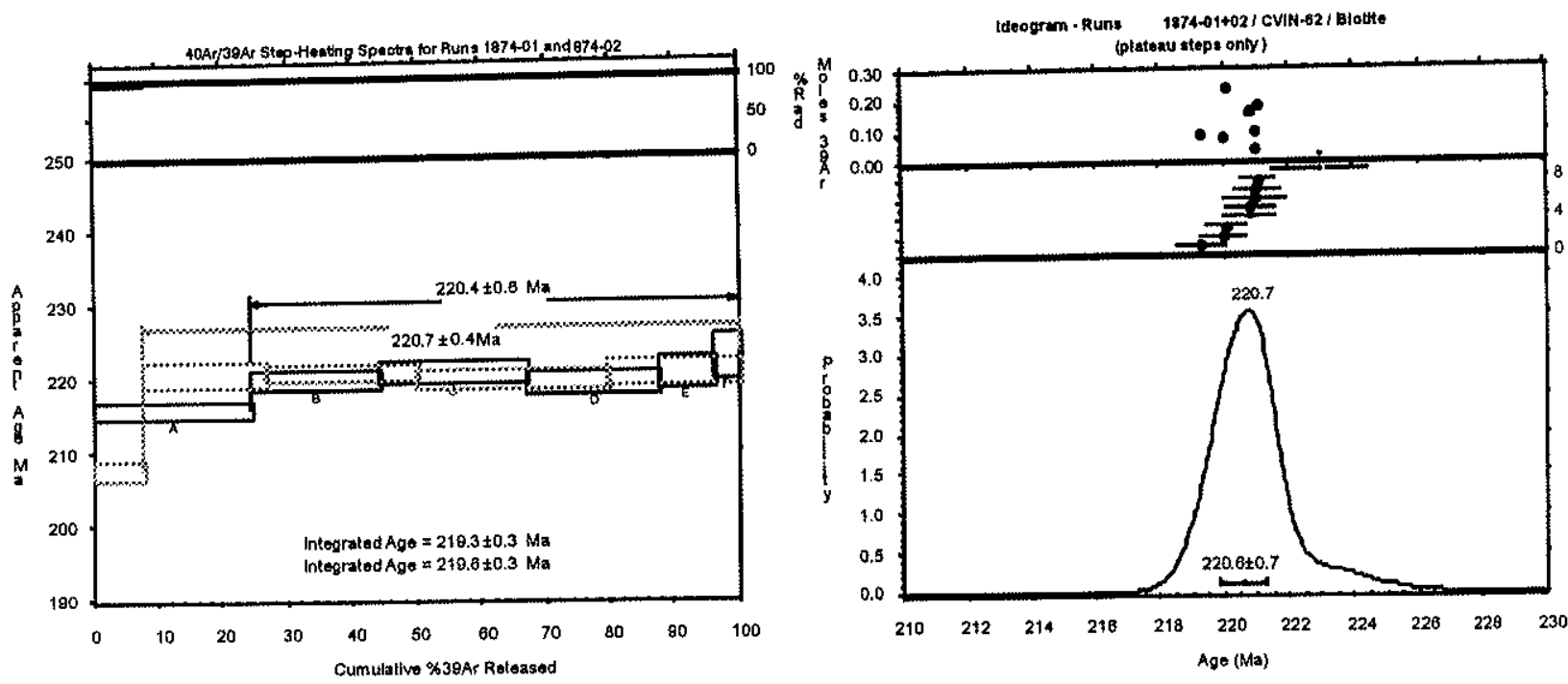

1876 / CVIN-40 / Biotite
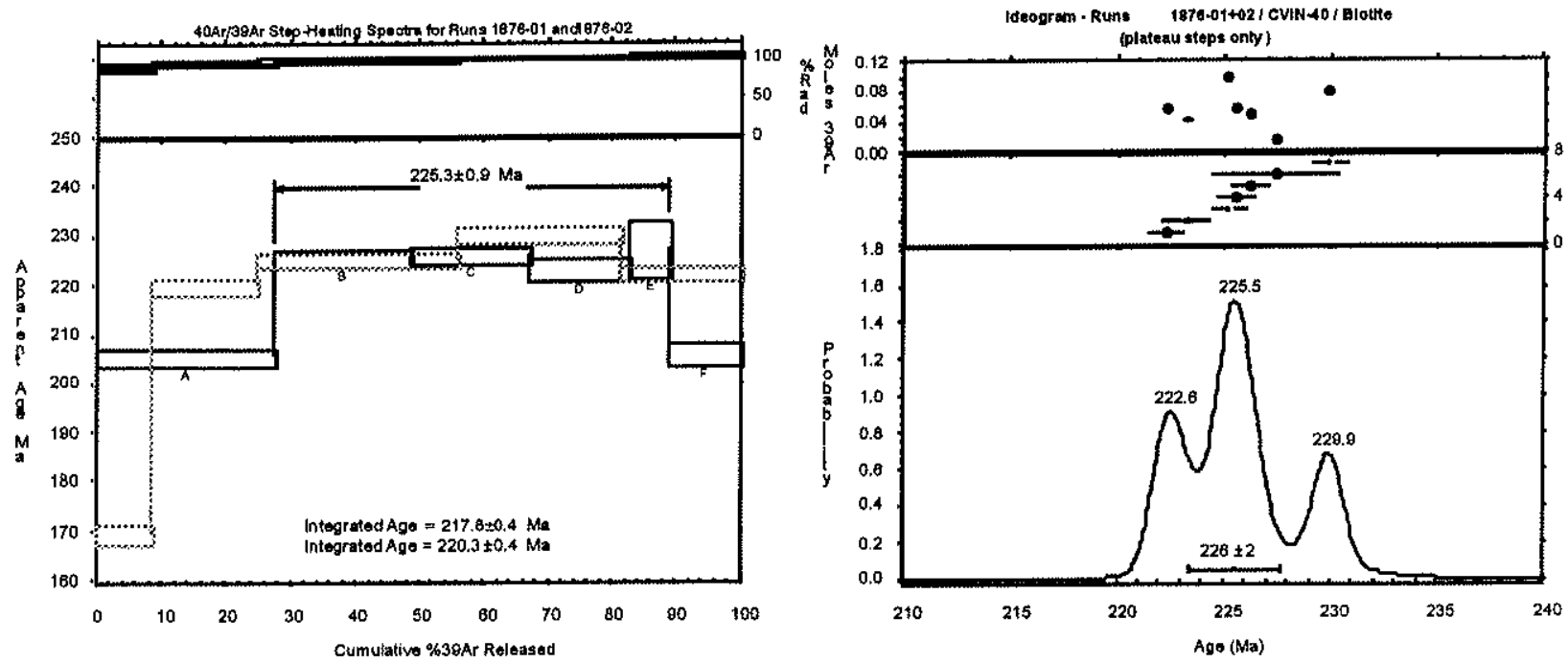

Figura $13 \mathrm{~d}$. Metassedimentos Unidade La Victoria. 
1894 / CVIN-59 / Muscovite
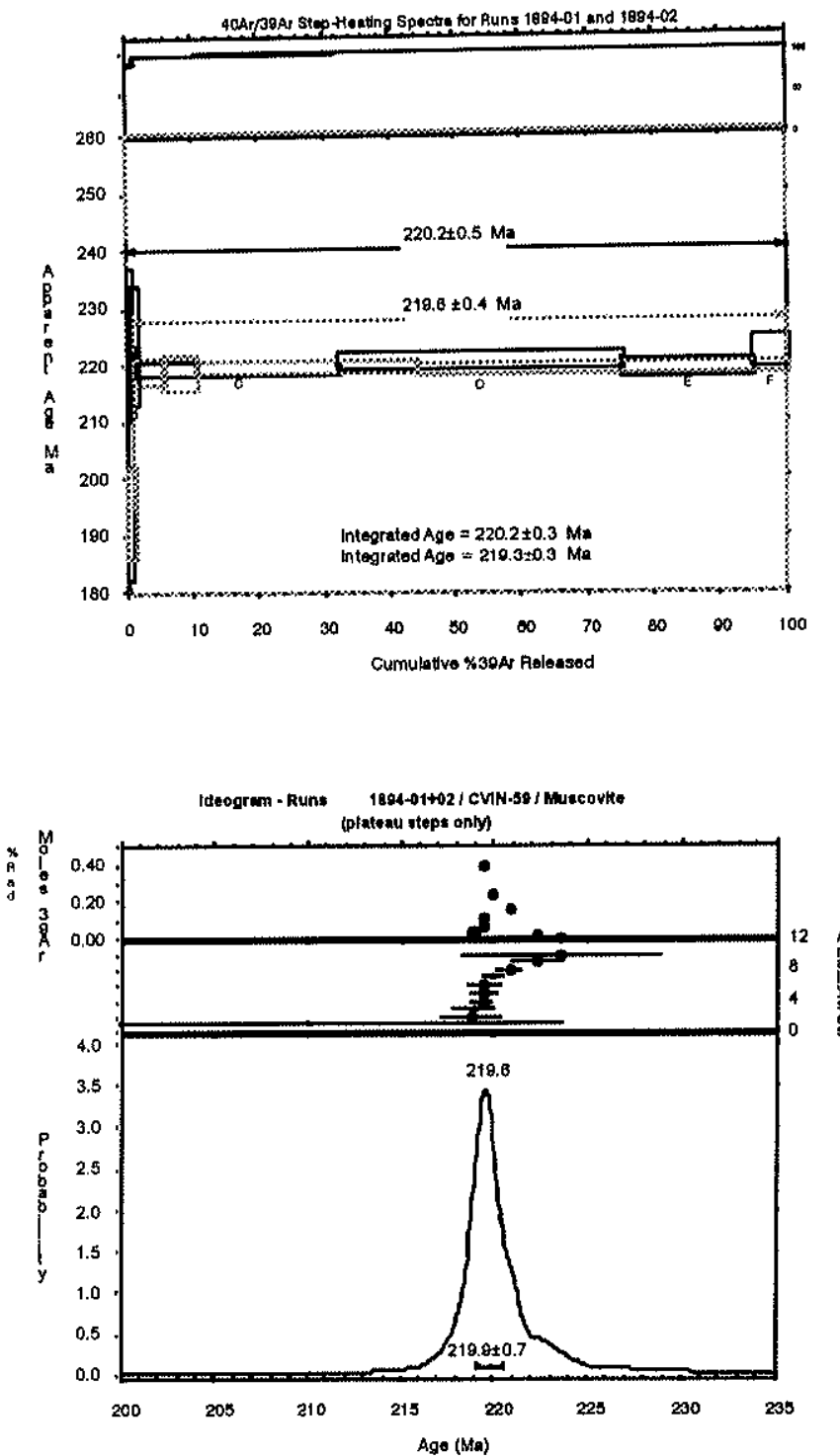

Figura 13 d. CONT Metassedimentos Unidade La Victoria. 
1870 / CVIN-84 / Blotite
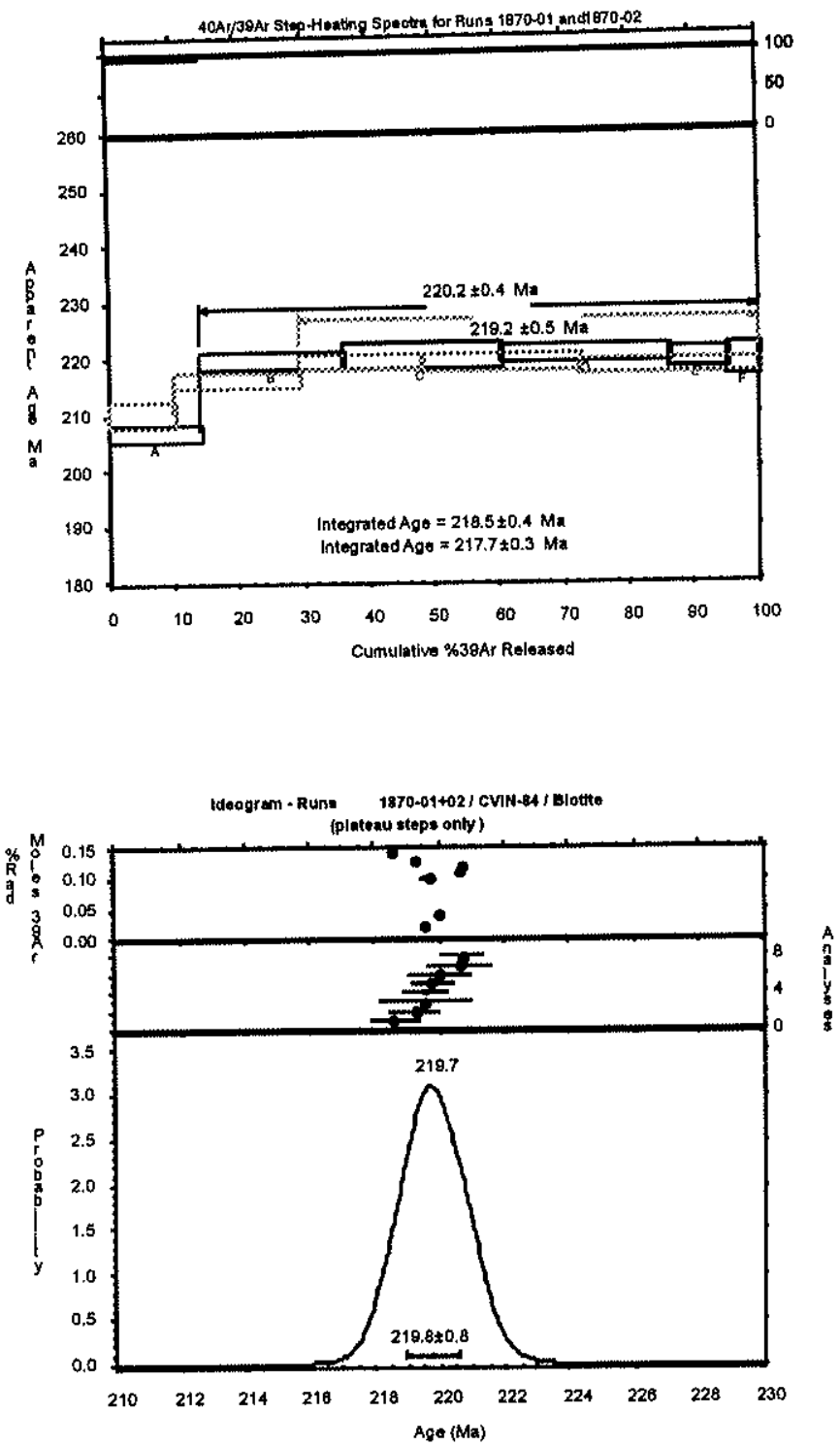

Figura 13 e. Metassedimento anfibólico de La Bocana. 
(f) 1875 / CVIN-69Amphlbole
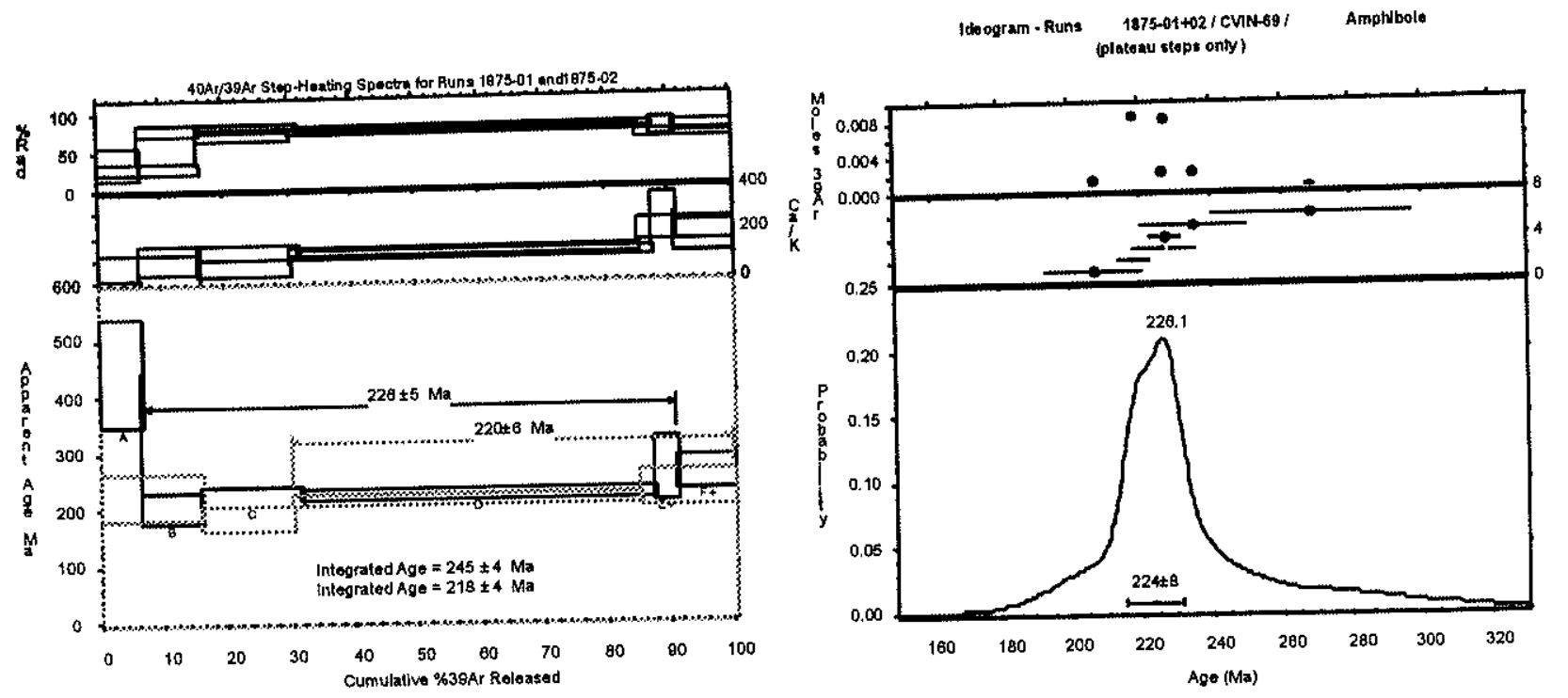

(g) 1891 / CVIN-19 / Biotite

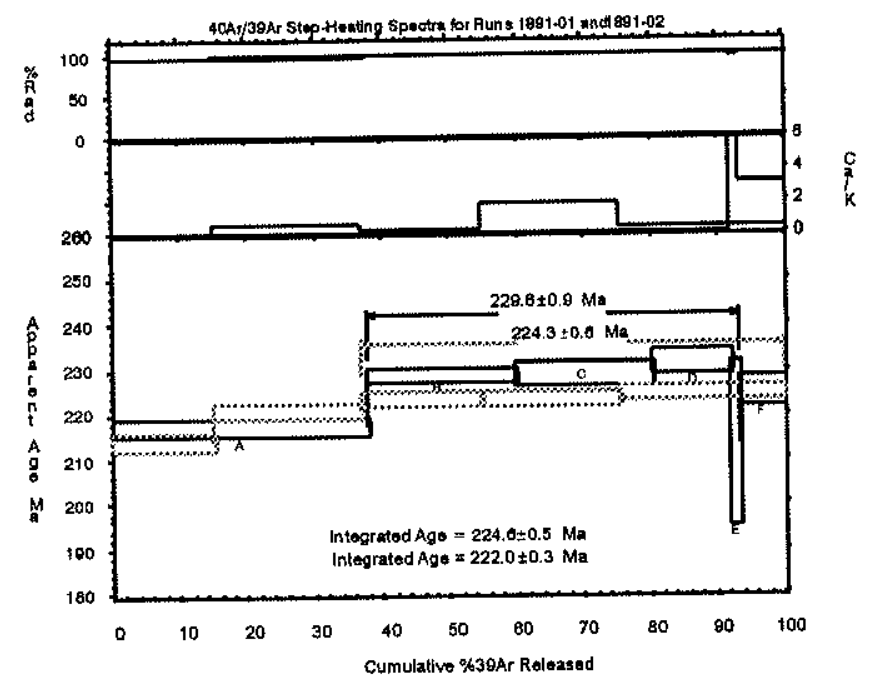

Figura 13. (f) Anfibolito de Piedras e (g) Dike granítico. 
(294 Ma) que pode indicar perda parcial de $\mathrm{Pb}$ num dos núcleos, e portanto, não registra a idade de formação do zircão. $\mathrm{A}$ idade ${ }^{206} \mathrm{~Pb} /{ }^{238} \mathrm{U}$ mais antiga corresponde à análise 10.1 de um núcleo euédrico sem estrutura interna definida, com uma idade aparente de $1013 \mathrm{Ma}$. Outros núcleos forneceram idades aparentes neoproterozóicas de $571 \mathrm{Ma}$ e $551 \mathrm{Ma}$. As idades mais jovens se distribuem em três locais da curva concórdia. A idade mais antiga desse período corresponde ao ponto 1,2, com uma idade aparente de $269 \pm$ 6.8 Ma em sobrecrescimento com estrutura bandeada fraca. Idades similares são reportadas para um ponto de análise do plutão de Marcabelí e um ponto de análise para um metassedimento (metassedimento de La Bocana, ponto 2,2 , fig. 14) o que pode representar um evento com significado geológico. $O$ grupo principal de idades apresenta uma idade média ponderada de $239,6 \pm 7,3$ Ma para 6 pontos (MSWD 1,3, probabilidade de ajuste 0,24) em zircões com estrutura oscilatória bem definida e em sobrecrescimentos com estrutura oscilatória regularmente definida. Esta idade é considerada como a idade de cristalização do corpo, similar à idade obtida para o plutão de Marcabeli dentro do intervalo de erro. A idade mais antiga encontrada para um zircão euédrico com zonação oscilatória para o plutão de La Florida é de $248 \pm 6 \mathrm{Ma}$ (ponto 4,1) e uma idade de $250 \pm 6$ Ma numa zona de núcleo com estrutura aparentemente oscilatória, o que indica o início de magmatismo precoce neste período de tempo, localizando o metamorfismo com idade mínima de $250 \mathrm{Ma}$. Idades mais jovens são obtidas para sobrecrescimentos com estrutura oscilatória regularmente definida (ponto 10,2 e 3,2) com média de idade ponderada de $215,5 \pm 7,8$ para 2 pontos (MSWD 0,35, probabilidade de ajuste de 0,56$)$. Estas idades são dificeis de serem interpretadas dentro do contexto geológico regional, mas como se verá adiante, podem corresponder às idades de migmatização regional registradas em metassedimentos associados a migmatitos. Estruturas de recristalização que truncam os sobrecrescimentos são ainda observadas, o que sugere uma evolução subseqüente desconhecida.

Os valores de $U$ do plutão de La Florida variam entre 159 e 630 ppm, com uma média de $426 \mathrm{ppm}$, e os valores de Th variam entre $20-79 \mathrm{ppm}$, com uma média de $40 \mathrm{ppm}$ para os dados no período Permo-Triássico (encarte 7). As razões $T h / U$ apresentam uma média de 0,13 para este período de tempo, valor sistematicamente inferior ao apresentado pelos zircões do plutão de Marcabelí e idênticos, como se verá, aos valores reportados para os granitóides de La Bocana. Os valores da razão Th/U mais altos encontrados para o plutão de La Florida são aqueles para os zircões que apresentam uma nítida zonação 
oscilatória, com valores comparáveis aos valores encontrados para o plutão de Marcabelí.

A idade de 217 Ma obtida neste granitóide pelo método Ar-Ar em muscovita (Fig. 13b), é interpretada como o episódio final registrado da exumação do orógeno no Triássico superior, relacionado à migmatização regional.

O granitóide de El Prado apresenta idade plateau Ar-Ar de 222,8 $\pm 0,5$ e $220,9 \pm 0,4 \mathrm{Ma}$ em biotita (Fig. 13b), similares às idades de resfriamento obtidas para o plutão de La Florida e às idades deformacionais registradas no plutão de Marcabelí, confirmando assim o resfriamento após a migmatização regional e exumação do orógeno no Triássico superior.

\section{Os Granitóides de La Bocana}

O granitóide de La Bocana apresenta zircões euédricos prismáticos bipiramidais, achatados facetados e alguns poucos achatados arredondados. As imagens de $C L$ permitem a observação de uma estrutura interna complexa, caracterizada pela formação de um núcleo normalmente anédrico e sem estrutura definida, manteado por um crescimento de zircão tipicamente com zonação oscilatória bem definida. É possivel ainda observar zonas de alta luminosidade, que parecem corresponder a zonas de recristalização tardias. As análises foram realizadas exclusivamente nos sobrecrescimentos com zonação oscilatória bem definida e, portanto, não foi obtido registro das idades dos núcleos mais antigos. A distribuição de idades na curva concórdia é simples, sendo que a totalidade das análises coloca-se concordantemente e de forma extremamente bem agrupada (Fig. 14). A idade média ponderada para as análises é de 232,2 $\pm 5,1$ Ma para 6 pontos (MSWD 0,029, probabilidade de ajuste de 1,0). Esta idade é considerada como de cristalização do corpo, similar às idades obtidas para o plutão de Marcabeli e La Florida.

Os valores de $U$ do granitóide de La Bocana variam entre 267 e 328 ppm, com média de $196 \mathrm{ppm}$ e valores de Th entre 23 e $37 \mathrm{ppm}$ com média de $31 \mathrm{ppm}$. A razão $T h / U$ é de 0,11 em média, similar ao valor obtido para o plutão de La Florida (encarte 7).

As análises Ar-Ar obtidas forneceram idades plateau bem definidas (Fig. 13c) de 215,9 $\pm 0,5 \mathrm{Ma}$ e $215 \pm 1$ Ma para um gnaisse granítico (CVIN-85) rico em granada intercalado com metassedimentos, de $219,4 \pm 0,8 \mathrm{Ma}$ e $219 \pm 0.4 \mathrm{Ma}$ 

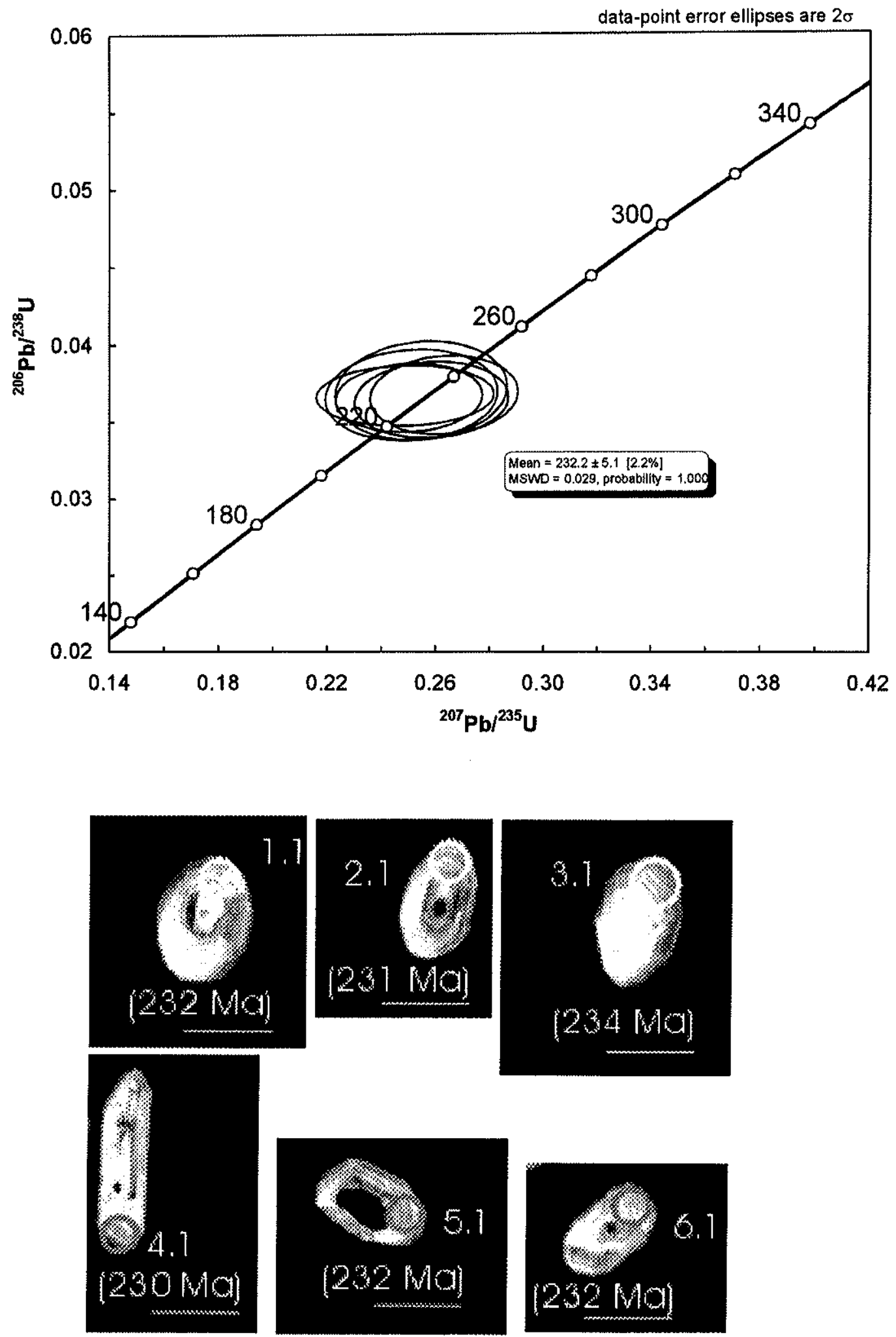

Figura 14. Granitóide La Bocana

a. Diagrama Concordia

b. Imagens de Catodo-luminescência

Tamanho da barra de escala 100 micras. 
para um gnaisse granítico similar (CVIN-83) e de 219,2 $\pm 0,4$ Ma e 218,6 $40,5 \mathrm{Ma}$ em muscovita para um gnaisse estreitamente relacionado a migmatitos (CVIN$60)$.

Um dique granítico não foliado que aparentemente corta os metassedimentos da unidade La Victoria fornece idades plateau Ar-Ar em biotita de 229,6 $\pm 0,9$ e $224,3 \pm 0,6 \mathrm{Ma}$ (Fig. 13g). A idade obtida sugere que 0 dique pode-se correlacionar com alguns granitóides da zona, indicando a existência de relaçōes de intrusão dos corpos graníticos com os metassedimentos para pelo menos um grupo de granitóides, possivelmente aqueles colocados de forma mais tardia no processo orogênico regional.

As idades conhecidas para os granitóides e ortognaisses da unidade La Bocana pelo método K-Ar em micas variam entre $207 \pm 6$ e $220 \pm 6$ Ma e uma idade $\mathrm{Sm}-\mathrm{Nd}$ isócrona granada-RT forneceu uma idade de $219 \pm 22 \mathrm{Ma}$ (Aspden et al., 1992b). Por outro lado, as idades K-Ar para o granitóide de Marcabeli variam entre $193 \pm 13$ e $221 \pm 6 \mathrm{Ma}$ (Aspden, et al., 1992b). Adicionalmente, Aspden et al. (1995) obtiveram uma idade U-Pb em monazita para o plutão de Marcabeli de 227,5 $\pm 0,8 \mathrm{Ma}$.

\section{Unidade metassedimentar La Victoria}

Os xistos da unidade La Victoria apresentam uma ampla variedade tipológica de zircões devido à sua natureza metassedimentar. Os cristais individuais se apresentam normalmente achatados e arredondados, mas é comum observar zircões prismáticos bipiramidais com as terminações pouco modificadas. Esta característica parece indicar um transporte não muito intenso dos sedimentos à bacia de acumulação. As imagens de $\mathrm{CL}$ permitem observar as diversas estruturas dos zircões detríticos. Observam-se núcleos com estrutura oscilatória e núcleos de alta luminosidade sem estrutura interna definida e recristalização comum. Aparecem zircões com os núcleos manteados e sobrecrescimentos com zonação oscilatória bem definida, e ainda zircões euédricos com zonação oscilatória fina, e finalmente grãos inteiros de zircão com alta luminosidade e sem estrutura interna apreciável. Pela natureza metassedimentar da rocha e a diversidade dos grãos, a distribuição de idades na curva concórdia é ampla e, no entanto, mesmo com a limitada base de dados, é possivel apreciar a formação de grupos de idades aparentemente coerentes (Fig. 15). A idade aparente ${ }^{206} \mathrm{~Pb} /{ }^{238} \mathrm{U}$ mais antiga corresponde a um sobrecrescimento amorfo a partir de um núcleo com aparente bandeamento 

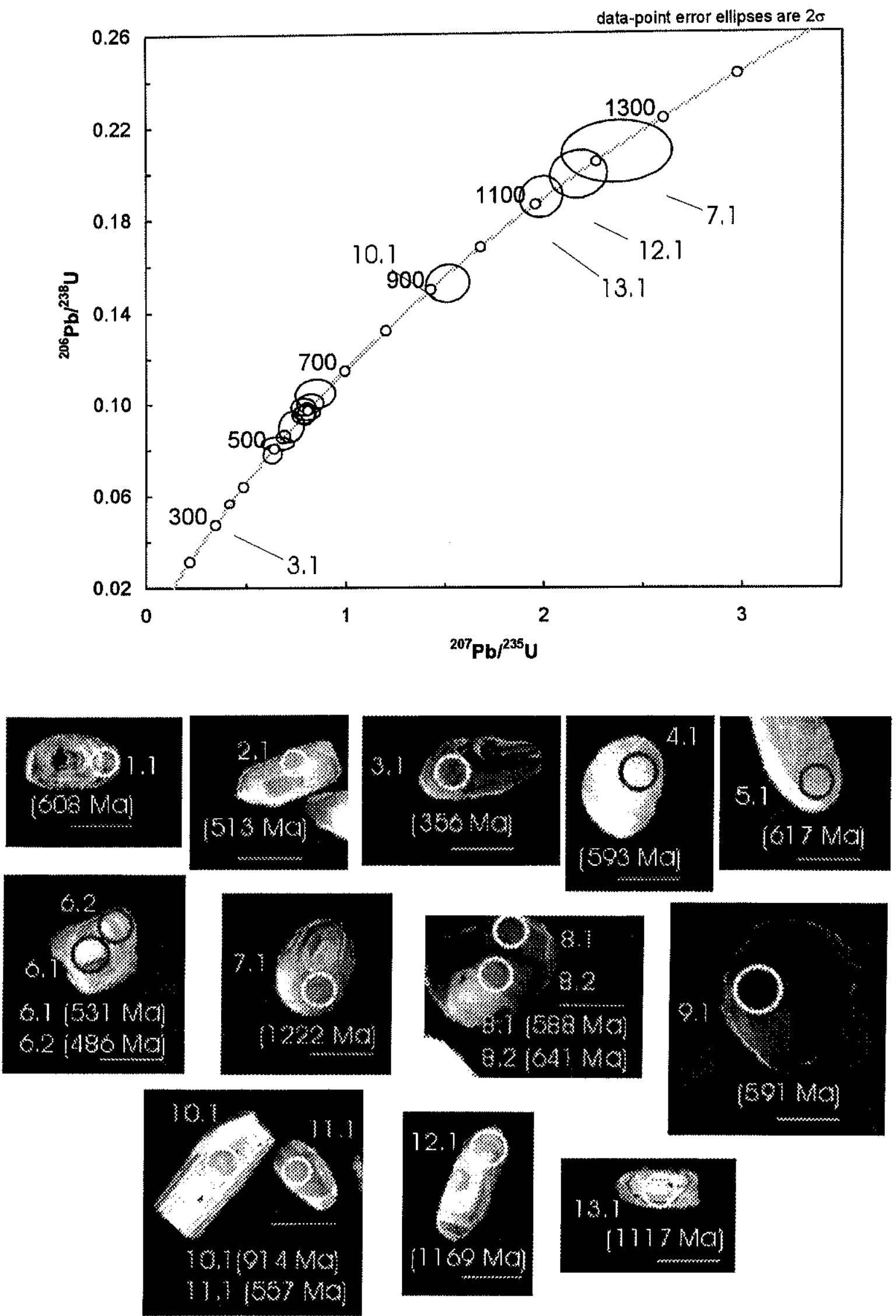

Figura 15. Metassedimentos da Unidade La Victoria

a. Diagrama Concordia

b. Imagens de Catodo-Juminescência

Tamanho da barra de escala 100 micras. 
interno (ponto 7.1). O anterior sugere uma história pelo menos paleoproterozóica para algumas das fontes da bacia. Outras idades nesse intervalo apresentam-se como sobrecrescimentos (ponto 12.1) ou como núcleos com estrutura interna oscilatória regularmente definida. $O$ grupo mais importante de idades apresenta-se entre 500 e $630 \mathrm{Ma}$ aproximadamente em zircões de diferente morfologia e estrutura interna, marcando o aporte importante de material de idade Brasiliana. A idade mais jovem obtida para o metassedimento é de $356 \pm 4 \mathrm{Ma}$ num sobrecrescimento com zonação nitidamente oscilatória (ponto 3.1), isto é, de fonte magmática. Esta idade fornece a idade máxima para o metamorfismo regional do complexo metamórfico como sendo do Misisipiano Inferior e o aporte de granitóides à bacia desta idade.

Os valores de $U$ dos zircões do metassedimento variam amplamente entre 172 e $1151 \mathrm{ppm}$ e os valores de Th entre 0,1 e 2,14 ppm. As razóes Th/U variam entre 0,1 e 2,14 (encarte 7), refletindo a grande variedade de materiais de aporte à bacia sedimentar.

Idades plateau Ar-Ar obtidas para metassedimentos da Unidade La Victoria da mesma área (CVIN-62 e 59, encarte 2) no córrego Primavera na parte central da área de estudo forneceram idades plateau em biotita de 220,4 $\pm 0,6 \mathrm{Ma}$, $220,7 \pm 0,4 \mathrm{Ma}$ e $220,2 \pm 0,5 \mathrm{Ma}, 219,6 \pm 0,4 \mathrm{Ma}$ respectivamente, similar às idades de resfriamento obtidas para os corpos igneos (Fig. 13d). A amostra CVIN-40 para leste da zona de estudo (encarte 2 ) forneceu uma idade plateau um pouco mais antiga de $225,3 \pm 0,9 \mathrm{Ma}$ mas o espectro apresenta-se perturbado, sugerindo que a idade corresponde de maneira geral às idades obtidas para os outros metassedimentos. As idades Ar-Ar obtidas parecem refletir o soergimento regional do orógeno da mesma forma que os resultados obtidos para os plutões, mas o metamorfismo certamente deve ser mais antigo que o Triássico Superior.

\section{Xistos anfibólicos de La Bocana}

Para os xistos anfibólicos de La Bocana, intercalados com migmatitos (Fig. 7 foto 13) foram obtidos poucos dados analíticos. Os zircões analisados correspondem a cristais hexagonais achatados, mas outros grãos apresentamse fragmentados e anédricos. As imagens de $\mathrm{CL}$ mostram zircões com núcleos sem estrutura definida manteados com sobrecrescimento aparentemente bandeado irregularmente (Fig. 16). Foram obtidas 4 idades aparentes 

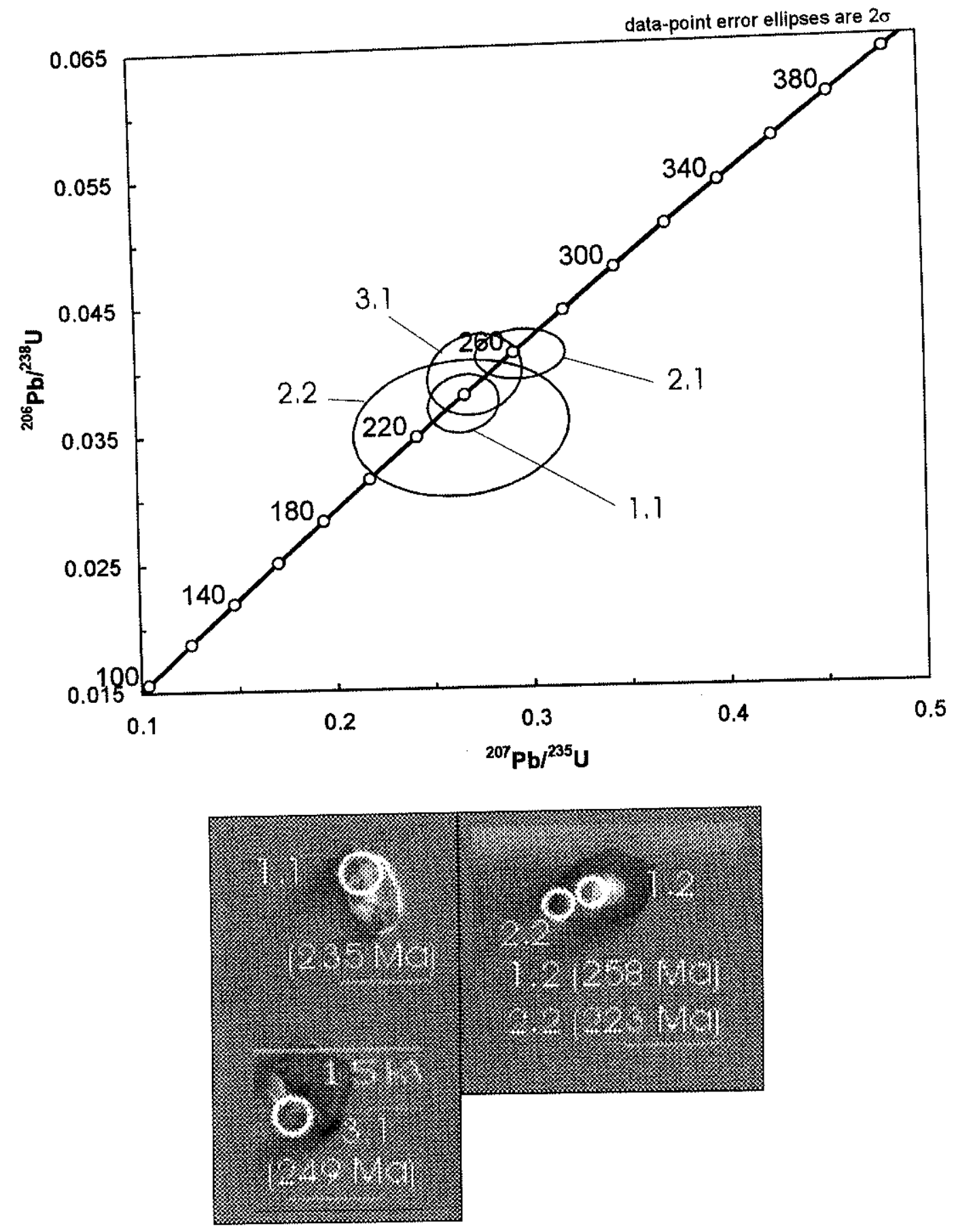

Figura 16. Metassedimentos de La Bocana

a. Diagrama Concordia

b. Imagens de Catodo-luminescência

Tamanho da barra de escala 100 micras. 
${ }^{206} \mathrm{~Pb} /{ }^{238} \mathrm{U}$, concordantes e relativamente bem agrupadas. A idade mais antiga encontrada é de $258 \pm 5$ Ma num núcleo sem estrutura interna definida (ponto 1.2). Esta idade poderia representar a idade do metamorfismo regional por estar sendo registrada num núcleo aparentemente metamórfico e por coincidir com idades similares de zircőes herdados, obtidas para os plutões de Marcabelí e La Florida (Figs. 15 e 16). Outra idade aparente, desta vez num sobrecrescimento com bandeamento mal definido, fornece uma idade de $250 \pm$ $8 \mathrm{Ma}$ (ponto 3.1), idêntica à anterior dentro da margem de erro.

Os valores de $U$ dos zircões do metassedimento básico variam fortemente entre 799 e 2977 ppm e valores de Th entre 164 e 465 ppm. As razões Th/U variam entre 0,05 e 0,29 (encarte 7 ).

Análise Ar-Ar obtida para a amostra CVIN 84 forneceu idades plateau de $220,2 \pm 0,4$ e $219,2 \pm 0,5 \mathrm{Ma}$ (Fig. 13e), muito similares às idades regionais obtidas para os outros metassedimentos e, por tanto, refletindo os processos regionais de resfriamento e exumação do orógeno.

\section{Anfibolito de Piedras}

Um anfibolito do grupo Piedras apresenta idades K-Ar cretácicas interpretadas como de rejuvenescimento isotópico (Aspden et al., 1992b). Idades mais antigas têm sido obtidas a $224 \pm 34,647 \pm 37$ Ma (Aspden et al., 1992b) e $743 \pm 14 \mathrm{Ma}$ (Kennerly, 1980) mas os resultados são duvidosos, vistos os baixos teores de $\mathrm{K}$ (Aspden et al., 1992b). Análise Ar-Ar obtida em anfibólio forneceu idade plateau de $226 \pm 5$ e $220 \pm$ Ma (Fig. 13f), compativel com a evolução geológica Triássica muito marcada no $\mathrm{CM}$ de El Oro. O significado desta idade no anfibolito pode refletir a colocação dos magmas máficos no Triássico, compativel com um ambiente distensivo neste período de tempo após o evento metamórfico colisional regional imediatamente anterior.

\subsubsection{Estrutura e alojamento do Plutão de Marcabeli}

Com o intuito de entender a relação temporal dos granitóides do CM de El Oro com os episódios metamórficos e deformacionais regionais, foi realizado um estudo de Anisotropia de Suscetibilidade Magnética (ASM) e de Orientação Preferencial de Forma (OPF) no plutão de Marcabeli. O objetivo do estudo é determinar seu mecanismo preferencial de colocação e suas relações com a tectônica regional. 
O plutão de Marcabeli ocorre como um sheet aproximadamente tabular alongado paralelamente à foliação $E-W$ das rochas encaixantes regionais (encarte 2, fig. 17). Na sua borda norte, o sheet está em contato com uma zona de cisalhamento destral com componente transcorrente dominante de direção $\mathrm{E}-\mathrm{W}$, determinada a partir de indicadores cinemáticos de cisalhamento, tanto nas encaixantes metassedimentares quanto no próprio plutão (Figs. 18b e 7, fotos 1 - 8). O estiramento do corpo, no sentido da zona de cisalhamento, sugere um controle estrutural importante na sua colocação.

O plutão de Marcabelí encontra-se dividido em três setores claramente diferenciados (Fig. 18a). A parte sudoeste do corpo apresenta texturas dominantes magmáticas (Fig. 18b) com plagioclásio euédrico zonado e normalmente sem orientação preferencial. A deformação é apenas evidente pela recristalização do quartzo. A parte média do corpo, considerada transicional, apresenta texturas de deformação com importante alinhamento de biotita, formação de ribbons de quartzo com recristalização extensiva. Ocorre ainda microfraturamento em micas com preenchimento de quartzo indicando possivelmente a presença de líquido durante a deformação (Fig. 18b). Finalmente, o extremo nordeste do corpo apresenta texturas miloníticas muito bem desenvolvidas, com estruturas tipo S-C, formação de bandas de cisalhamento $\left(C^{\prime}\right)$ e mica-fish indicativas de movimentação destral (Fig. 18b). Muscovita e sillimanita estão recristalizadas na foliação (Fig. 18b), indicando 0 desenvolvimento de cisalhamento em alta temperatura.

\subsubsection{Resultados de ASM}

A distribuição dos 28 pontos de amostragem são apresentados na figura 19 , os resultados médios dos parámetros escalares e direcionais obtidos do estudo da ASM são apresentados no anexo 2 e os elipsóides magnéticos obtidos no anexo 1. A amostragem abrange a totalidade do corpo e, portanto, fornece informação sobre as zonas com textura magmática até aquelas fortemente deformadas.

A fábrica magnética no interior do plutão é concordante com a estrutura regional observada nos metassedimentos e com a foliação medida em campo no próprio plutão (Figs. 17 e 20). A foliação magnética mergulha moderada a fortemente para NW (Fig. 20), enquanto a lineação magnética, subhorizontal, alinha-se para NEE (Fig. 20), de forma similar á lineação medida nos 
FIGURA 17.

MAPA ESTRUTURAL DO COMPLEXO METAMÓRFICO DE EL ORO

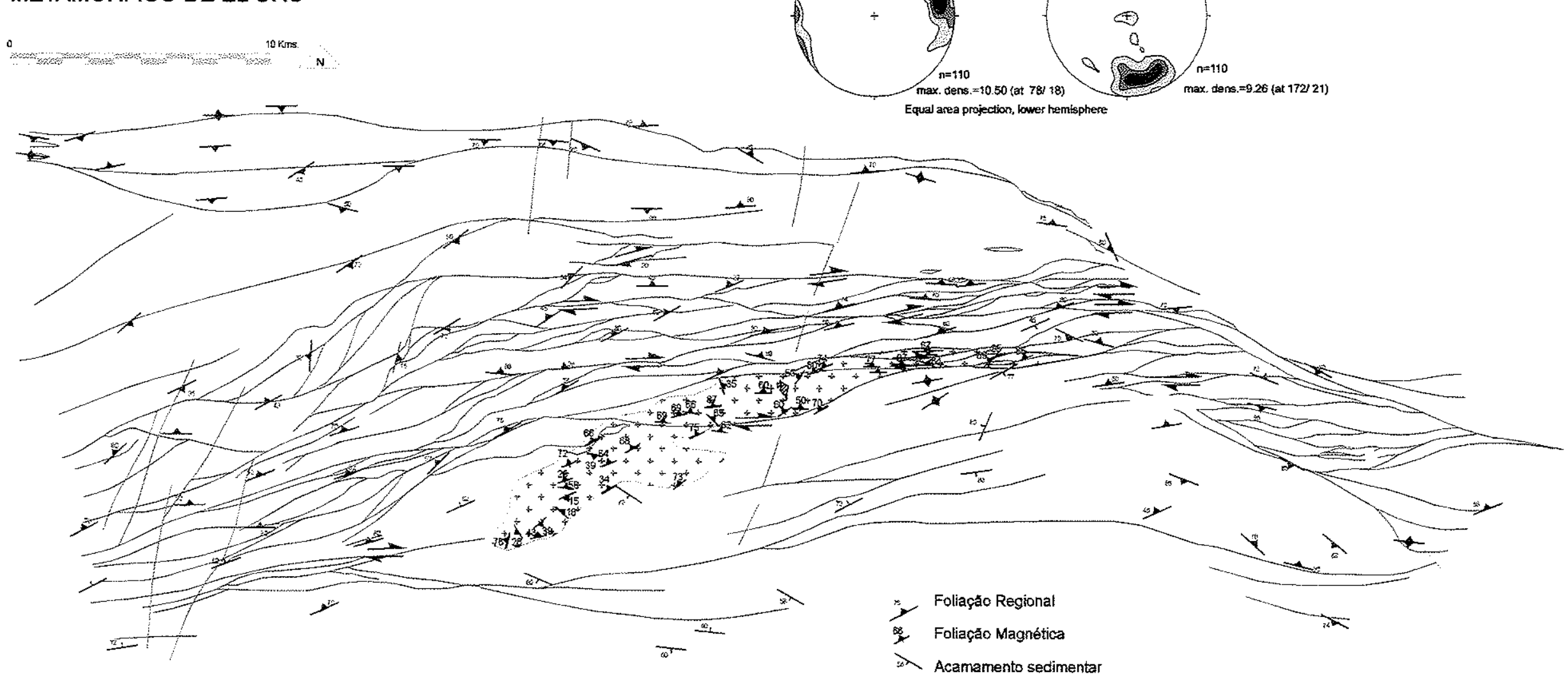



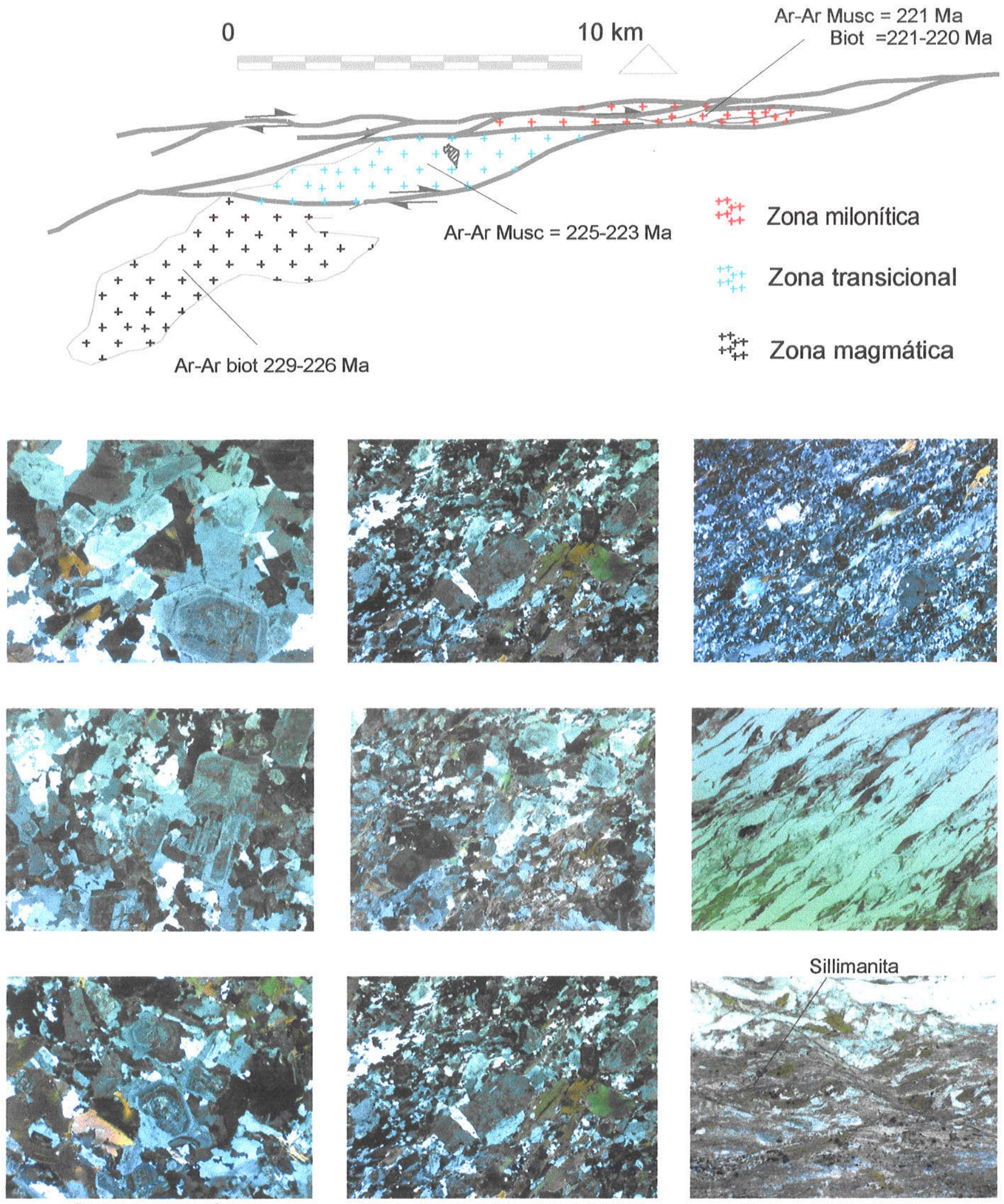

Texturas de caráter Transicional

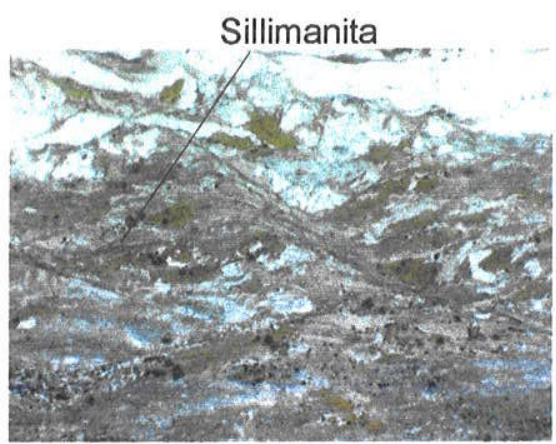

Texturas miloníticas

Figura 18. Mapa do plutão de Marcabeli mostrando as zonas de dominância magmática, transicional e milonítica. 


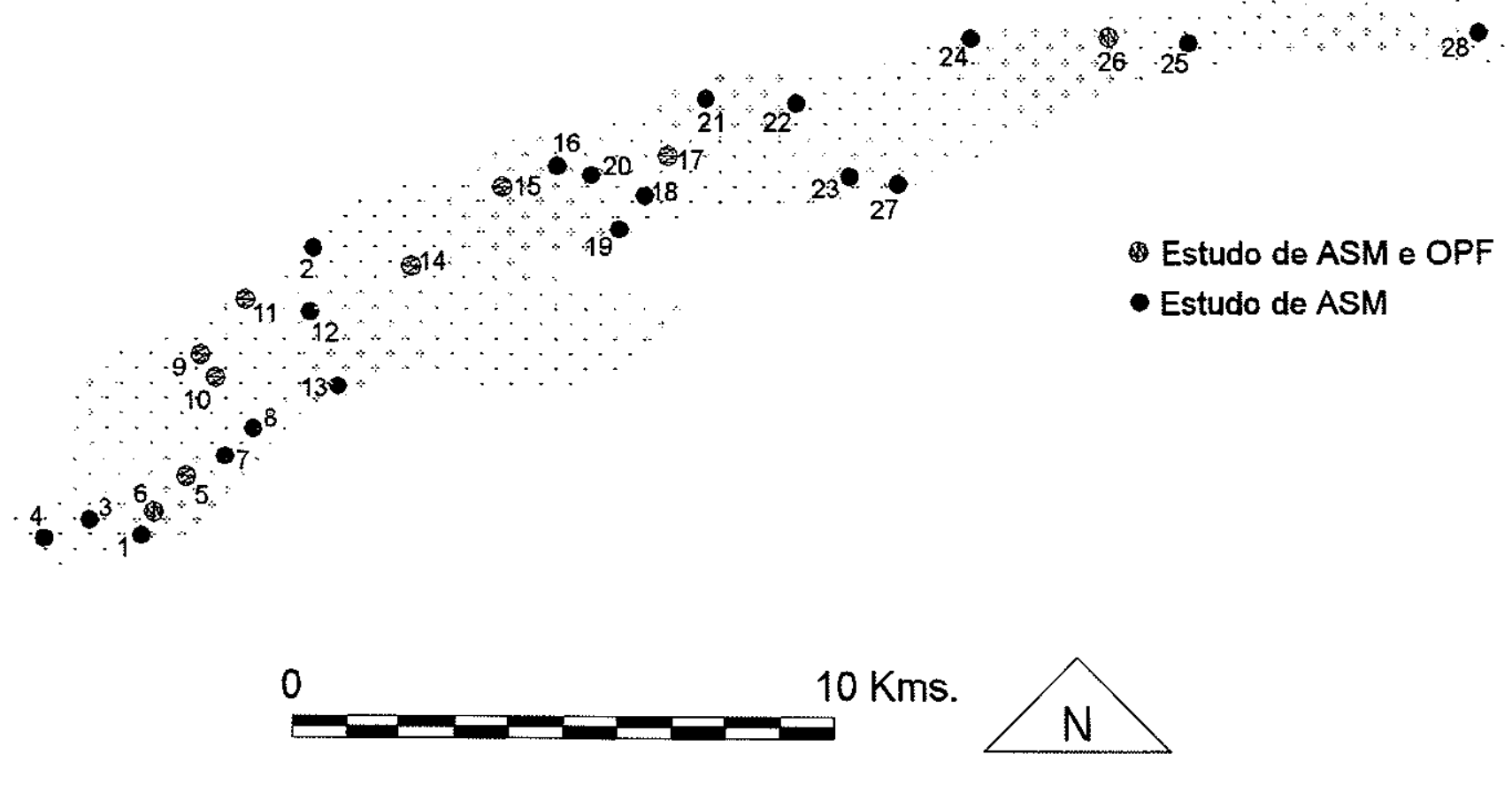

Figura 19. Localização de pontos para estudo de ASM e OPF Plutão de Marcabelí, Província de El Oro, Equador. 
metassedimentos (Fig. 20). Estes resultados são compativeis com uma fábrica magnética controlada pelo movimento destral do cisalhamento de direção $\mathrm{E}-\mathrm{W}$.

A suscetibilidade magnética (SM) varia entre 19 e $311 \times 10^{-5} \mathrm{SI}$. Os baixos valores de SM em conjunto com a tendência ao decréscimo com o aumento da temperatura indica o caráter paramagnético da SM. As curvas termomagnéticas (Fig. 21) embora apresentem um comportamento tipicamente paramagnético, isto é, decréscimo da suscetibilidade com o incremento da temperatura, sugere ainda a presença de magnetita como observado na mudança de fase na amostra $E Q-28$ em $T \approx 550^{\circ} \mathrm{C}$ e $600^{\circ} \mathrm{C}$. Esta magnetita possivelmente está relacionada à deformação, já que a suscetibilidade média e - grau de anisotropia magnétic a $\left(P^{\prime}\right)$ apresentam tendência a aumentar na direção nordeste do corpo (Fig. 22), onde a deformação é mais forte. Por outro lado, a curva obtida para a amostra EQ-12, que apresenta pouca deformação, não registra formação de magnetita (Fig. 21). Finalmente, o grau de anisotropia magnética varia de $4 \%$ a $36 \%$ com valores mais altos aproximando-se da zona de cisalhamento, isto é, na direção SW para NE. Isto sugere uma relação direta da anisotropia magnética com o cisalhamento regional.

A forma do elipsóide de suscetibilidade varia de prolato na parte nordeste do corpo a oblato na parte média (Fig. 22). O caráter prolato do elipsóide na parte nordeste é compativel com uma extensa deformação pelo cisalhamento destral com forte estiramento como observado em mapa. A forma dominante oblata na parte intermediária do corpo poderia corresponder a uma zona intermediária de deformação que durante a dinâmica do cisalhamento sofre transpressão. Em outras palavras, a deformação seria compartilhada no granítico no momento do alojamento com componente de cisalhamento puro nesta parte. A parte sudoeste do corpo apresenta baixa anisotropia de suscetibilidade magnética, baixos valores de suscetibilidade e um caráter mais neutro na forma do elipsóide magnético (Fig. 22). Neste setor o elipsóide magnético apresenta-se ligeiramente prolato. É possivel que a parte sudoeste do corpo apresente em menor grau os efeitos da deformação do plutão.

\subsubsection{Resultados de OPF}

O estudo de orientação preferencial de forma de trama de biotita foi efetuado para seis sítios na parte sudoeste do corpo (EQ-5, 6, 9, 10,11), duas amostras na parte central $(E Q-14,15)$ e duas amostras na zona de maior deformação (EQ17-26)(Fig. 19). 

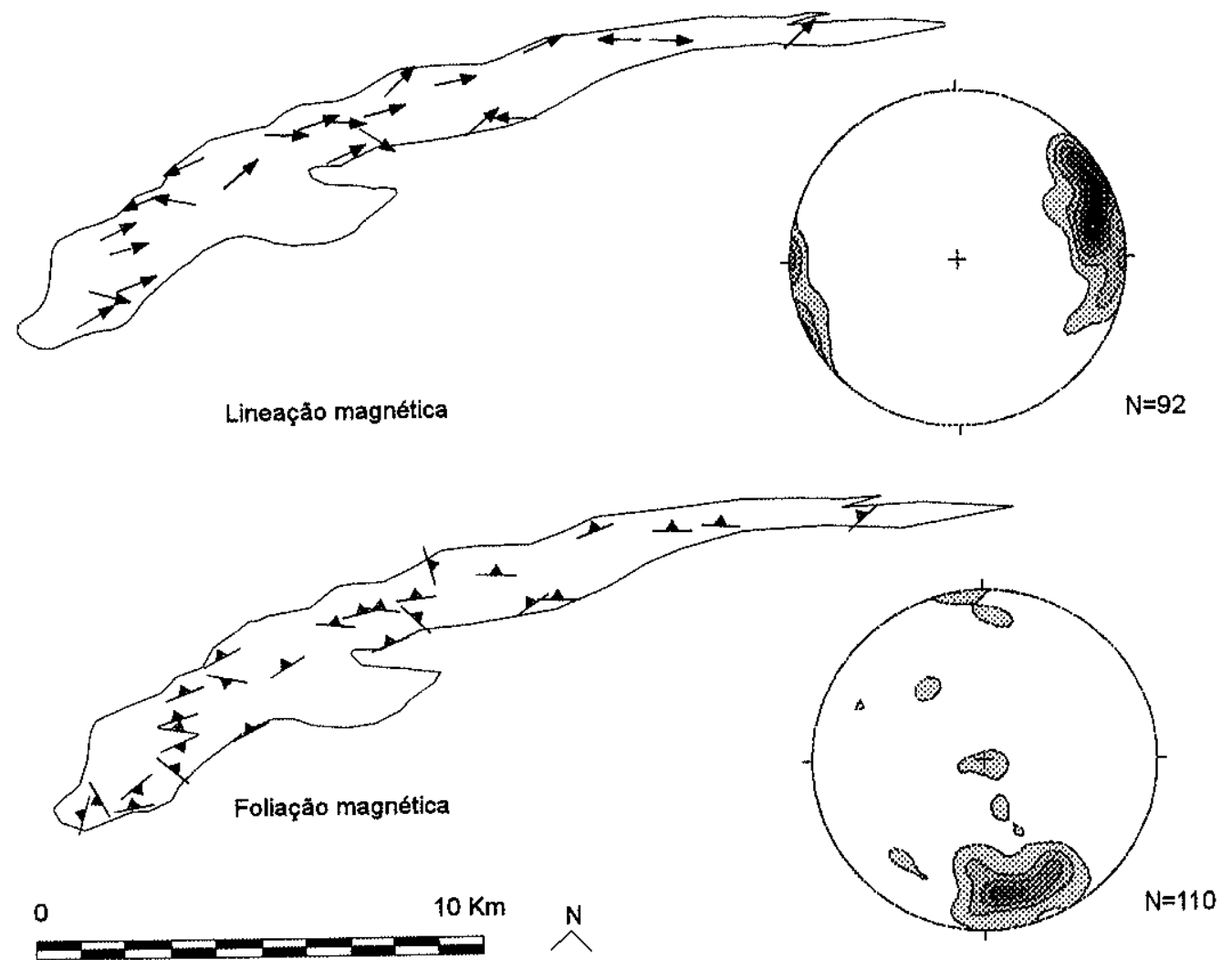

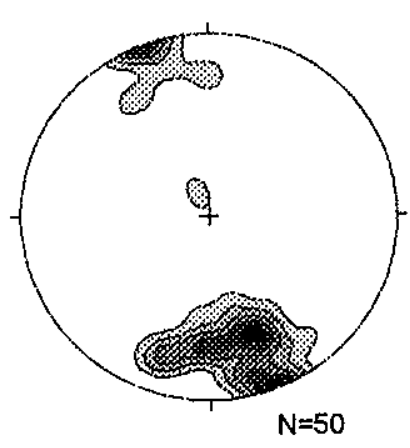

Follaçăo medida no Plutão

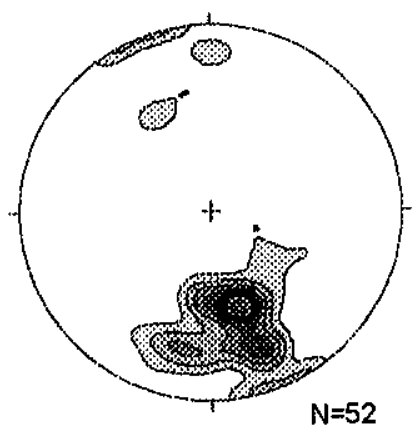

Foliaçăo na encaixante regional

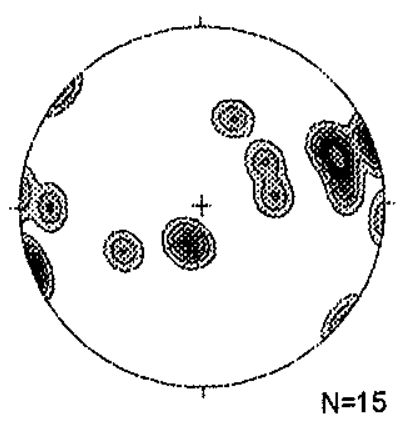

Lineação encaixante regional

Figura 20. Mapa de lineação e foliação magnética. São mostrados tambem os estereogramas respectivos e estereogramas das encaixantes regionais. 


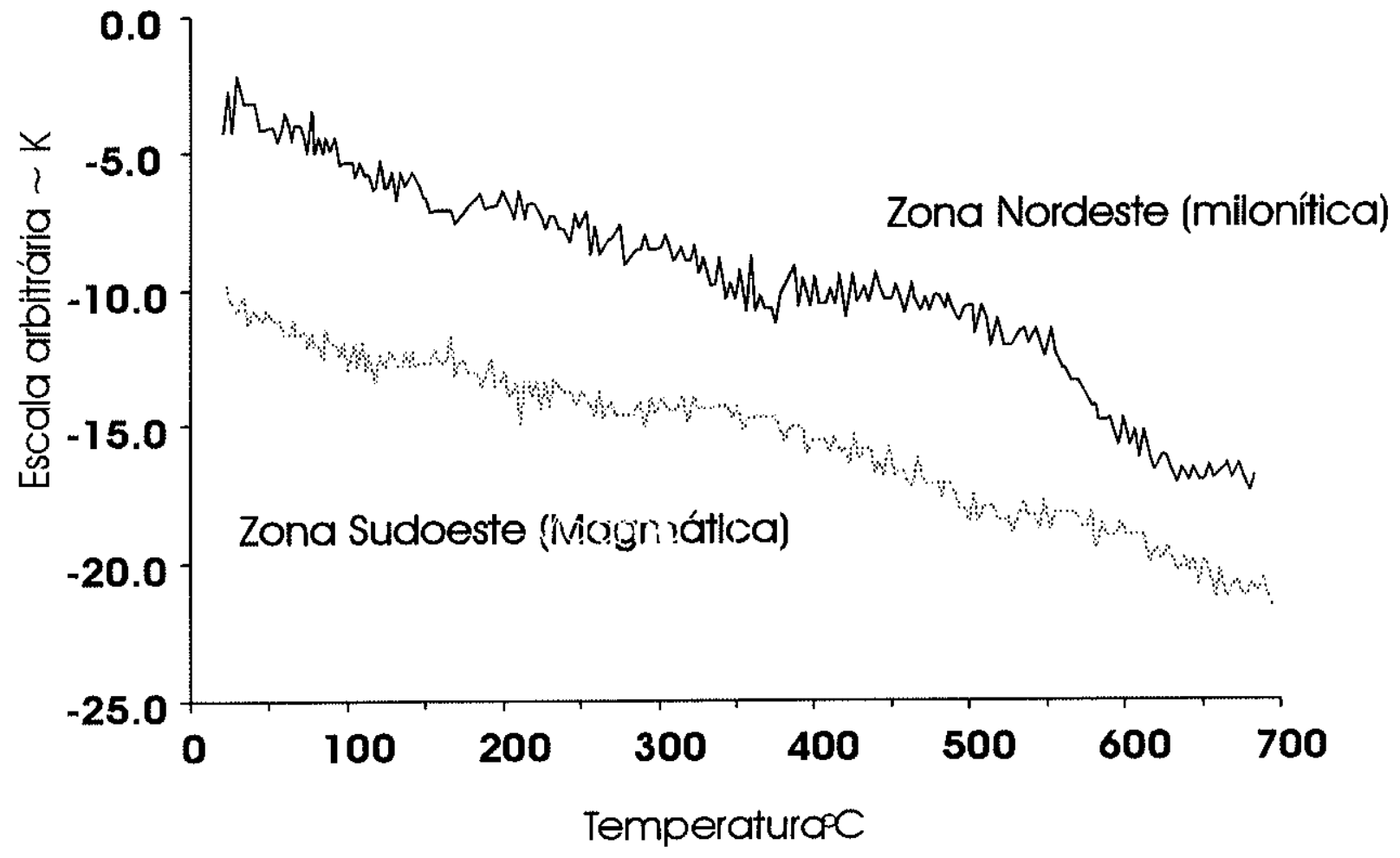

Figura 21. Curvas termomagnéticas para duas amostras do Plutão de Marcabelí. Curva preta amostra CVIN 28, curva cinza CVIN 12. 

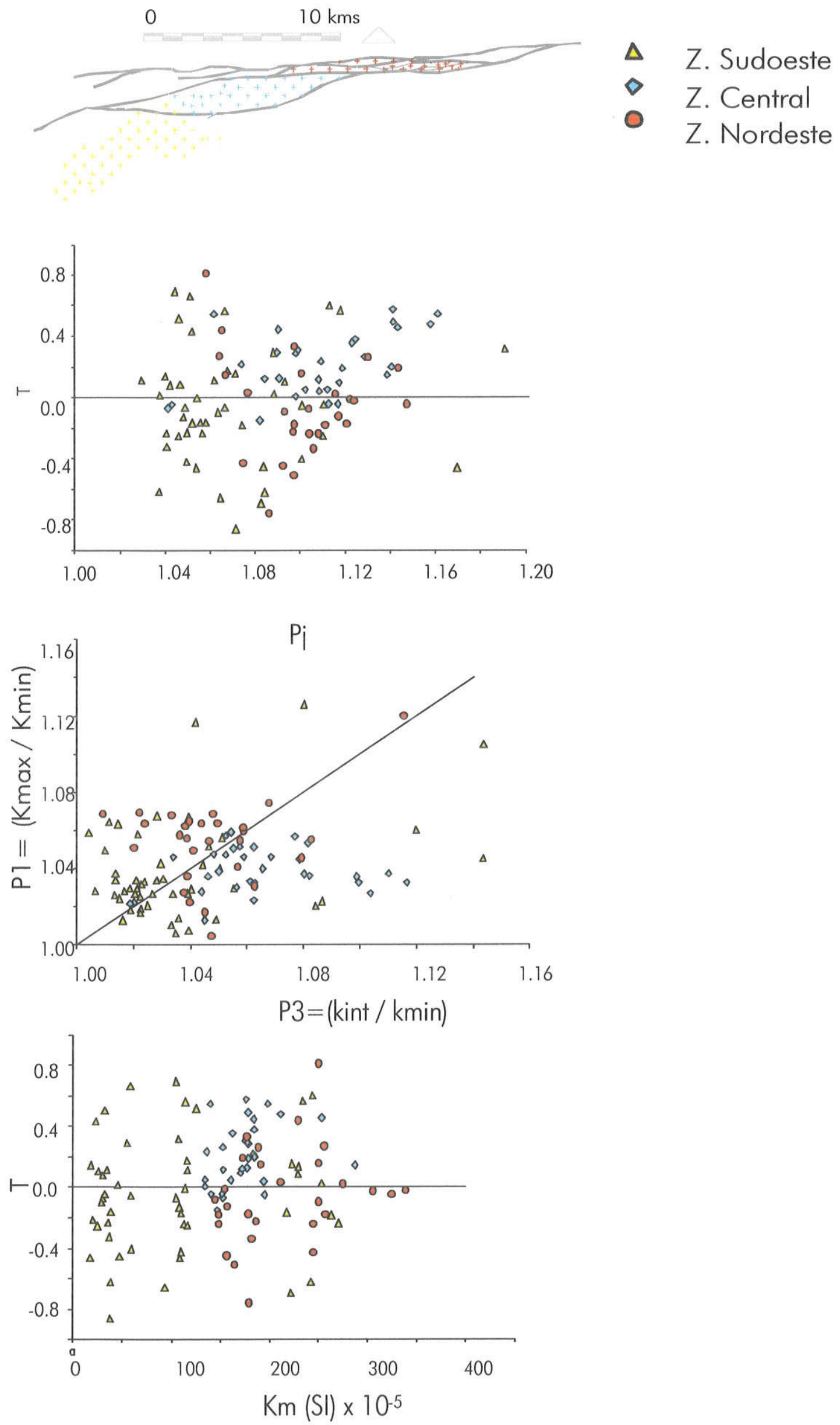

Figura 22. Parâmetros magnéticos Plutão de Marcabelí. 
Os resultados obtidos indicam a convergência dos dados na formação de elipsóides na maior parte dos métodos de análise empregados (Capítulo 4.1.5 anexo 3). Em linhas gerais, os resultados obtidos pelos métodos do intercepto, média tensorial, média tensorial do tensor normalizado e média tensorial da equação da elipse fornecem resultados similares com bons agrupamentos. Os resultados sugerem que a fábrica é homogénea na escala de medida, independentemente do método de OPF utilizado. $O$ anexo 3 apresenta os valores do índice de incompatibilidade $(\sqrt{F})$, as direções médias principais (lineação e polo da foliação), o parâmetro de forma T e a anisotropia P'.

A lineação (A) para as amostras da zona sudoeste, em que predominam as texturas magmáticas, é subvertical com um máximo em 300/78. Uma amostra, contudo, forneceu uma direção 150/26 (método dos interceptos). De forma contrastante, as lineações obtidas na zona nordeste, em que predominam as texturas miloníticas, apresentam mergulho mais baixo, normalmente menor de $34^{\circ}$ até subhorizontal (Fig. 23). A foliação marcada pela biotita na zona sudoeste (magmática), apresenta um máximo na direção aproximada $\mathrm{N}-\mathrm{S}$ e mergulho subvertical (N345/84SW) ao passo que na zona nordeste (milonítica) ela é aproximadamente E-W e mergulho subvertical (N104/90). As duas amostras da zona intermediária (EQ14-15) apresentam os dois tipos de comportamento (Fig. 23). A amostra EQ-14 apresenta a lineação e foliação da trama mineral de forma similar à zona milonítica, ao passo que a amostra EQ15 apresenta comportamento similar ao observado na zona magmática. Este resultado provavelmente reflete a complexidade da deformação na zona de transição de regime magmático (SW) ao deformacional (NE).

Os dados sugerem ainda que na zona sudoeste, onde a lineação mergulha fortemente, corresponde à zona de alimentação magmática. A zona nordeste, onde a lineação possui mergulho mais baixo, deve refletir a rotação das micas na zona de cisalhamento.

\section{Comparação entre a ASM e a OPF e discussão}

O fato mais característico encontrado no estudo comparativo da ASM com a OPF é a inversão de $\mathrm{k} 1$ e $\mathrm{k} 3 \mathrm{com}$ as direções principais de trama mineral na parte sudoeste do corpo. Quando a trama é magmática, k1 aparece sistematicamente na posição $C$ (polo da foliação da biotita) e k3 (polo da foliação magnética) na posição de $\mathrm{A}$ (lineação de biotita). Esta inversão é 
SITIO 5 (CILINDRO 5A)
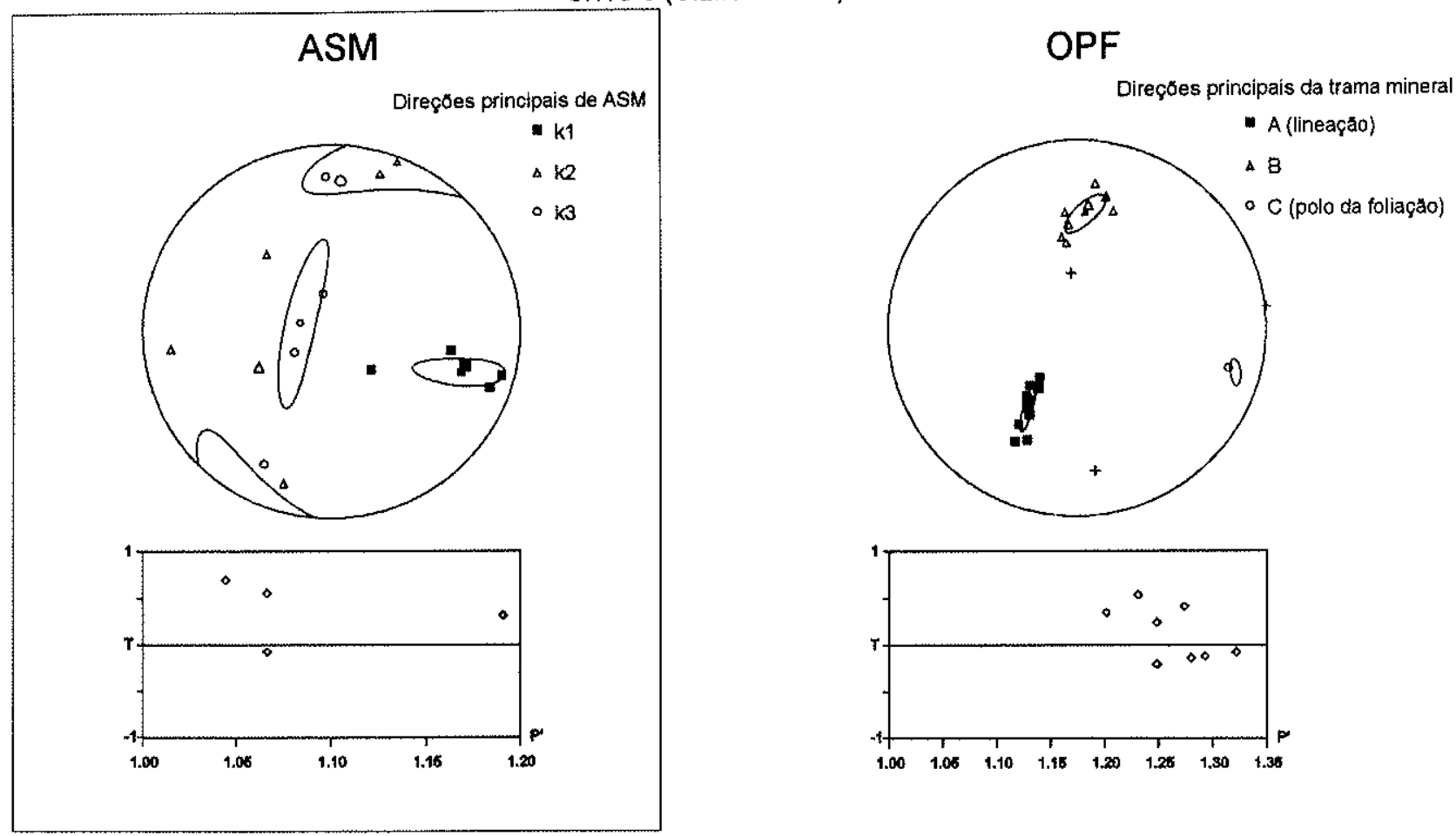

Método de Interceptos
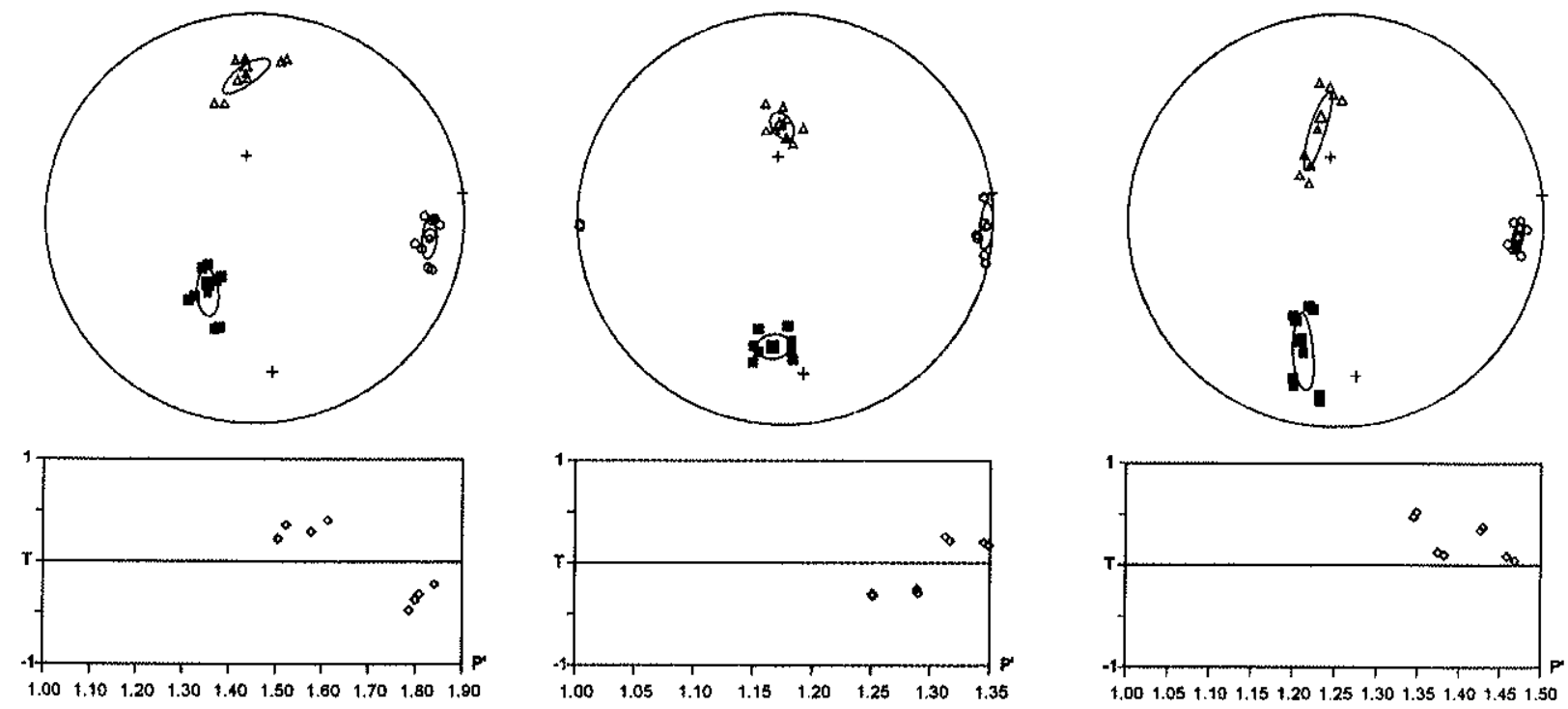

Tensor de Inércia

Tensor de Inércia - E

Tensor de Inércia - Normalizado

Figura 23. Projeção estereográfica de Schmid (hemisferio inferior) de dados direcionais de ASM e de trama mineral a partir de cilindros orientados. As elipses representam o desvio padrão para 1-sigma. 
SITIO 6 (CILINDRO 6A)
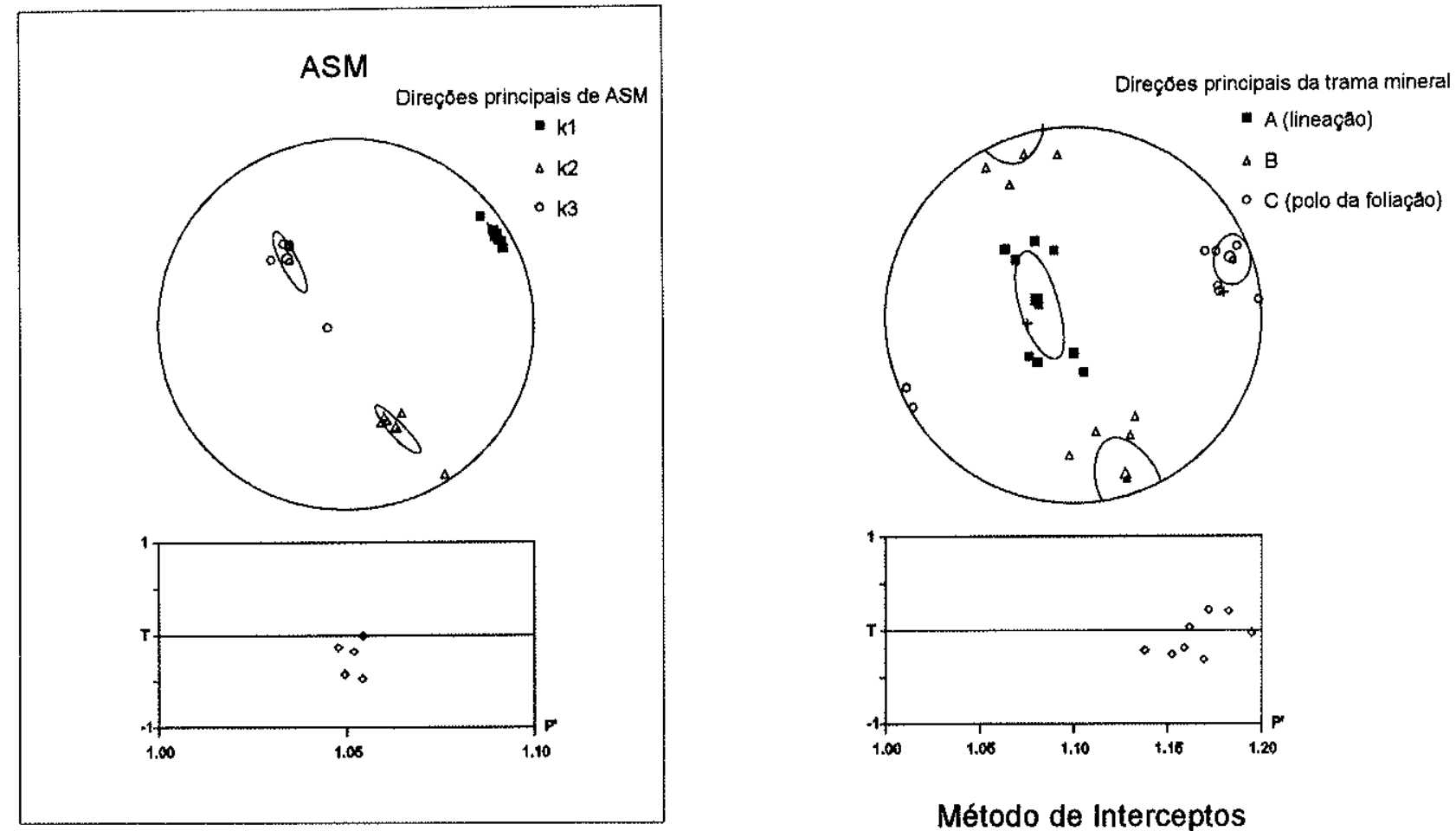

Método de Interceptos
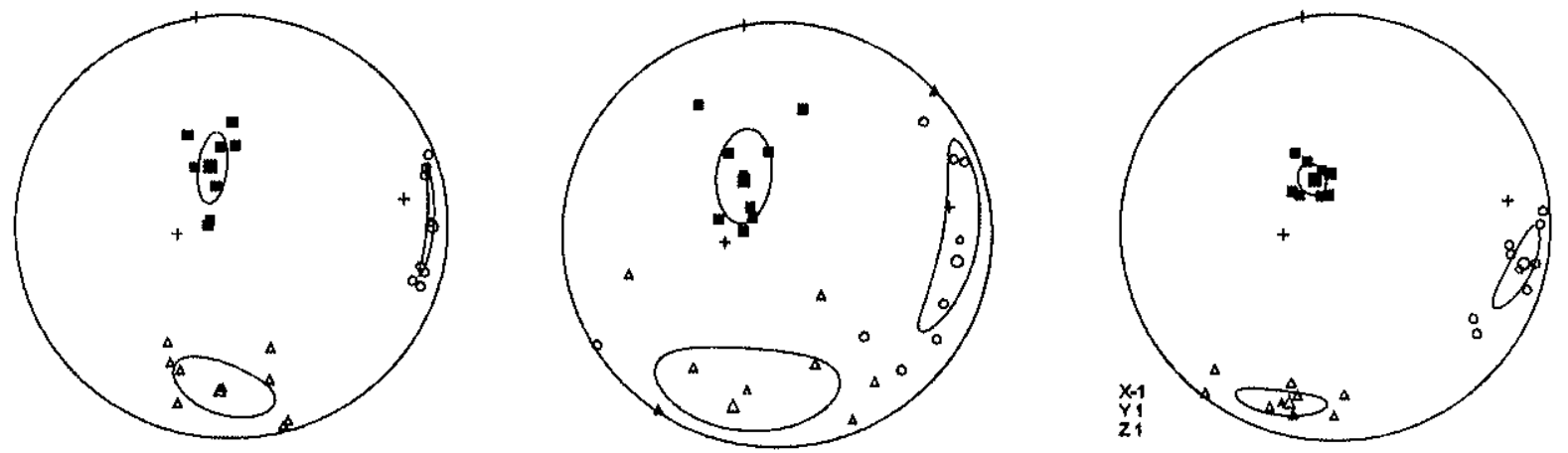

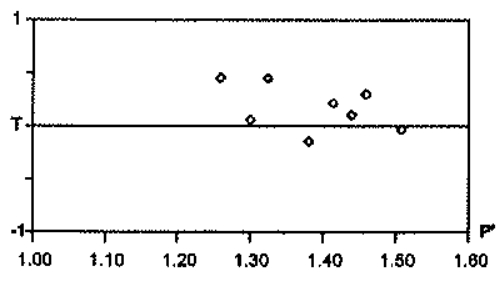

Tensor de Inércia

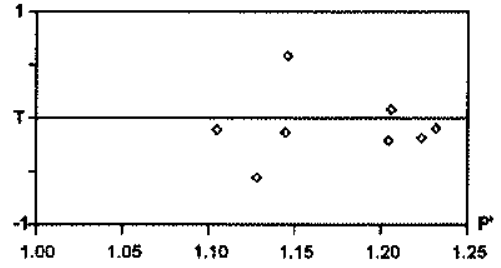

Tensor de Inércia - E

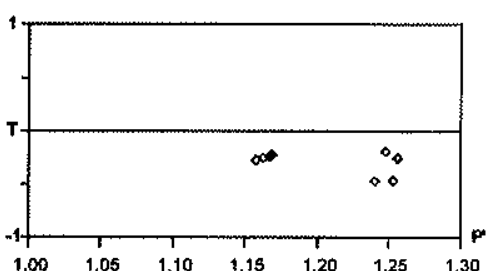

Tensor de Inércia Normalizado

Figura 23. CONT. Projeção estereográfica de Schmid (hemisferio inferior) de dados direcionais de ASM e de trama mineral a partir de cilindros orientados. As elipses representam o desvio padrão para 1-sigma. 
SITIO 9 (CILINDRO 9A)
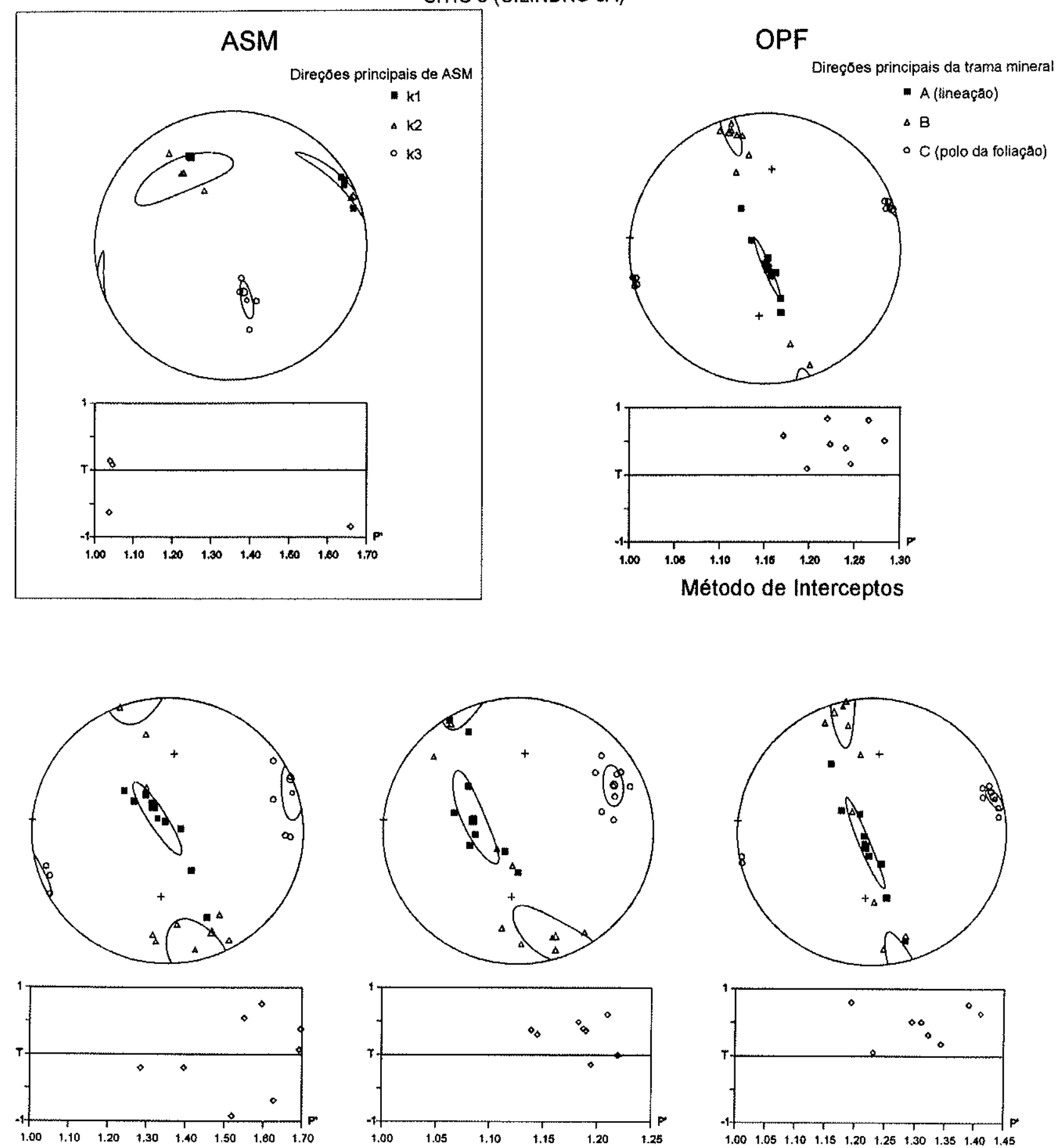

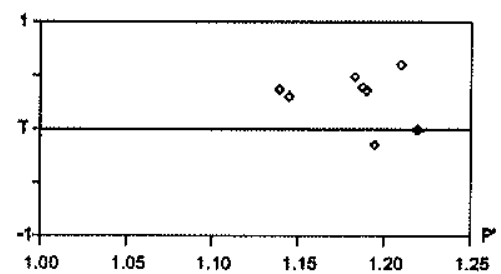

Tensor de Inércia -E

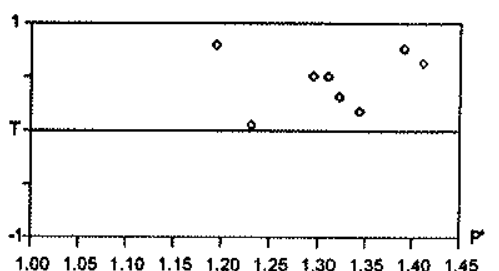

Tensor de Inércia Normalizado

Figura 23. CONT. Projeção estereográfica de Schmid (hemisferio inferior) de dados direcionais de ASM e de trama mineral a partir de cilindros orientados. As elipses representam o desvio padrăo para 1-sigma. 
SITIO 10 (CILINDRO 10B)
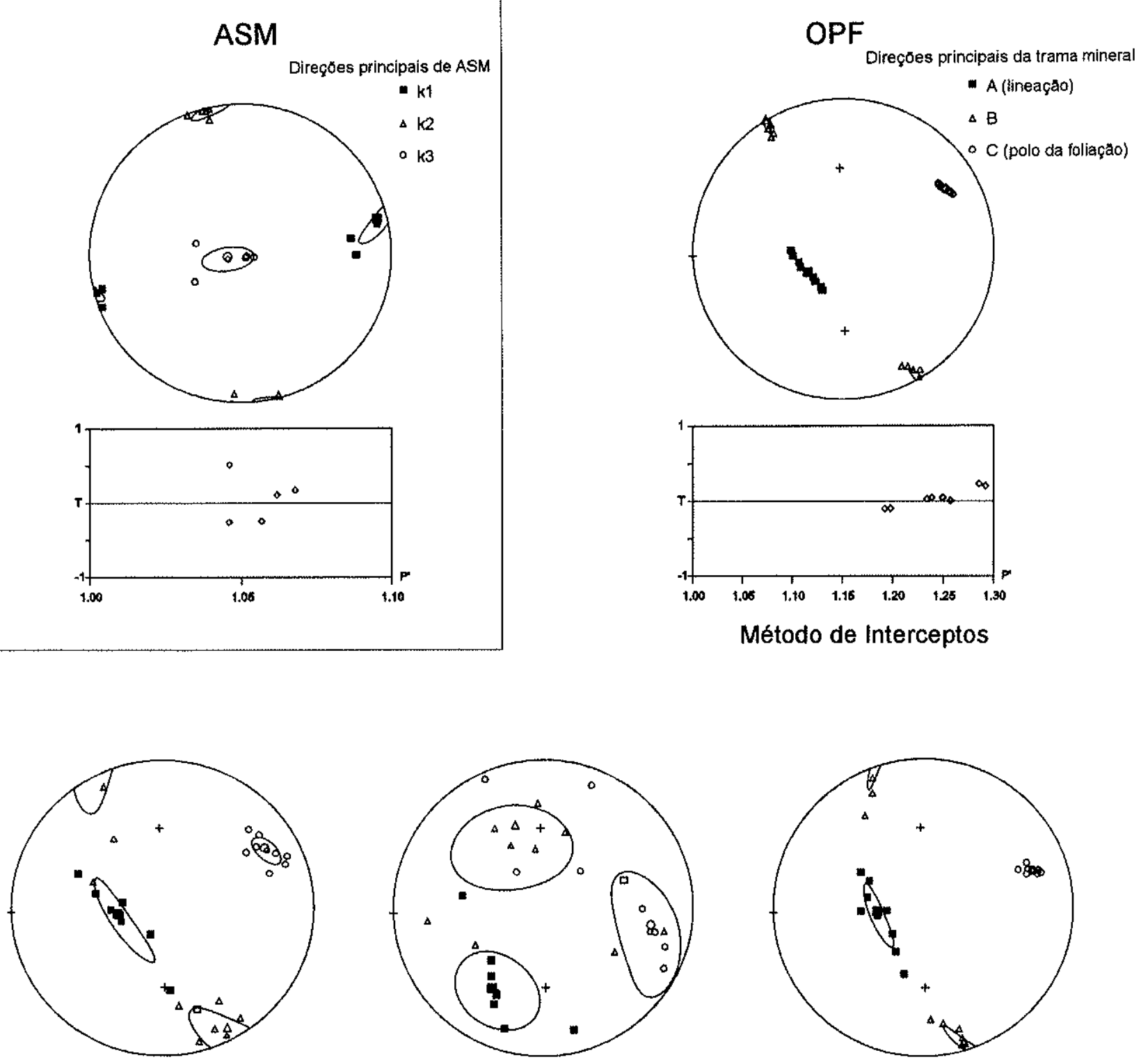

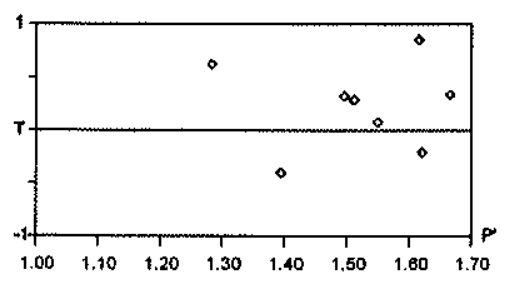

Tensor de Inércia

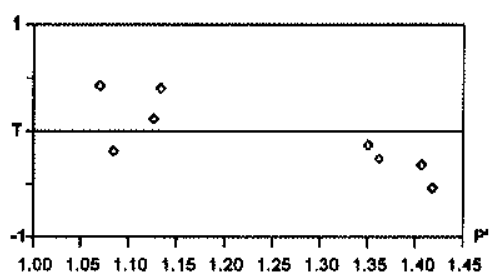

Tensor de Inércia - E

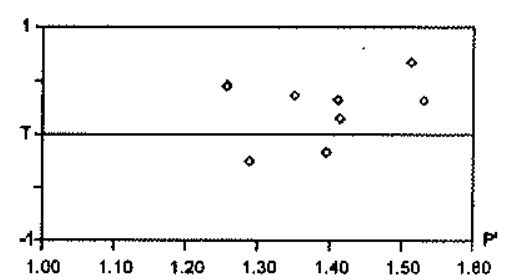

Tensor de Inércia - Normalizado

Figura 23. CONT. Projeção estereográfica de Schmid (hemisferio inferior) de dados direcionais de ASM e de trama mineral a partir de cilindros orientados. As elipses representam o desvio padrăo para 1-sigma. 
SITIO 11(CILINDRO 118)
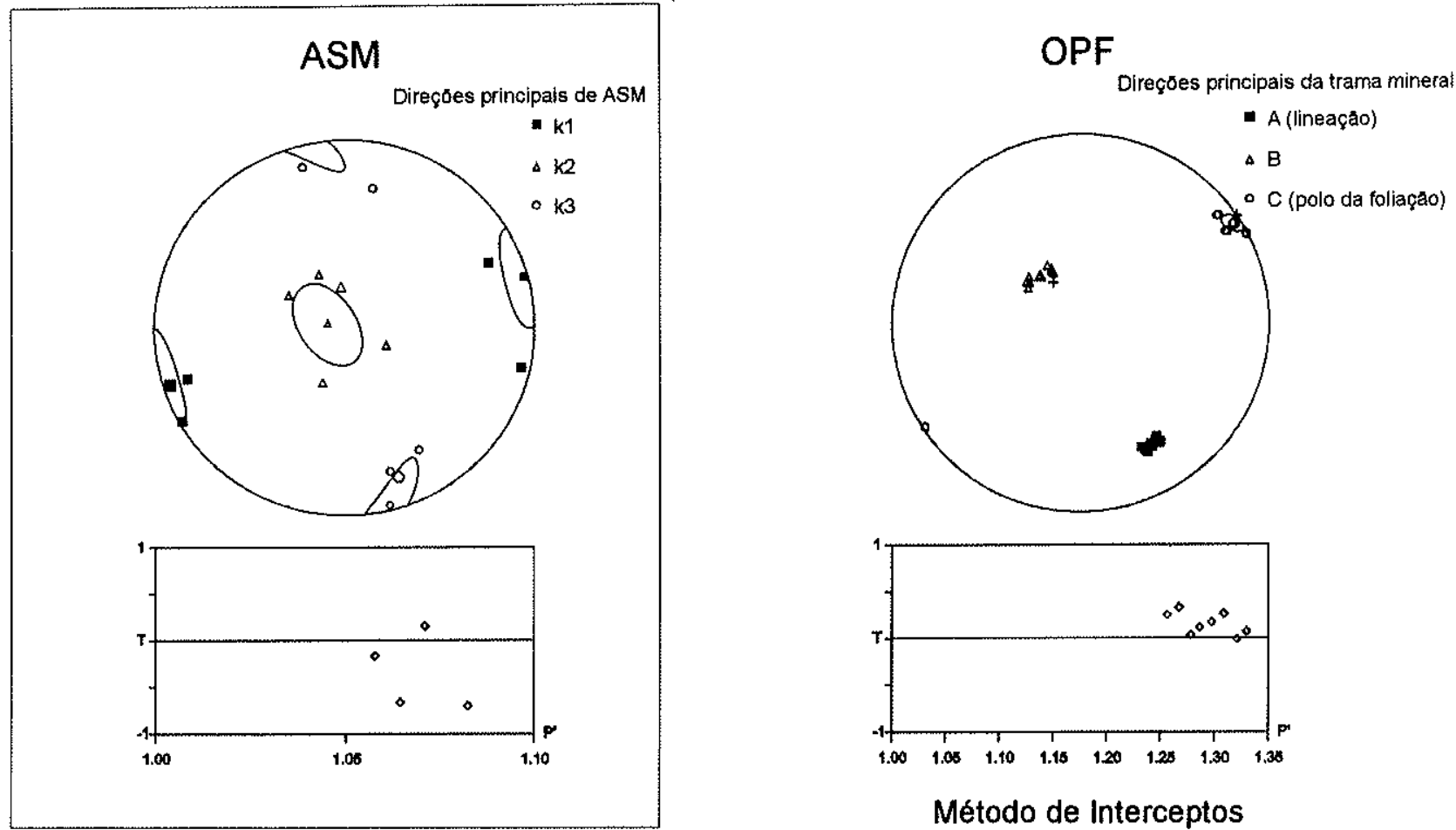

Método de Interceptos

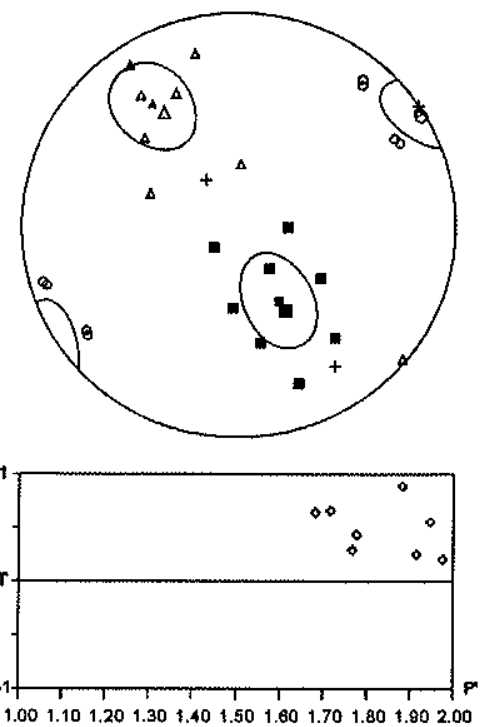

Tensor de Inércia
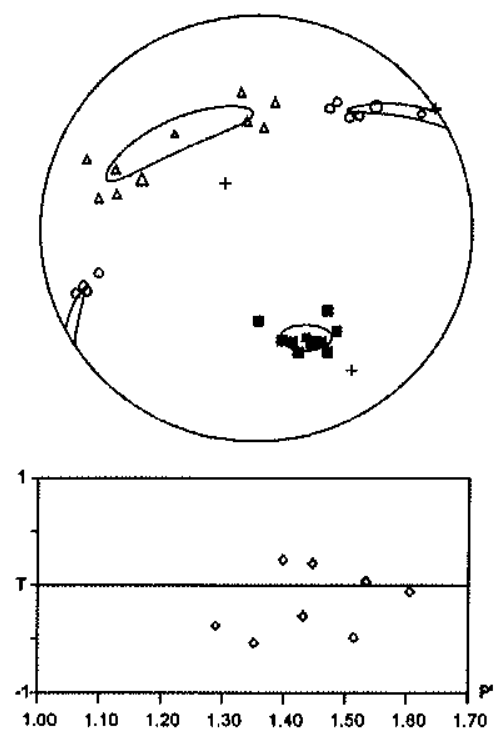

Tensor de Inércia - E
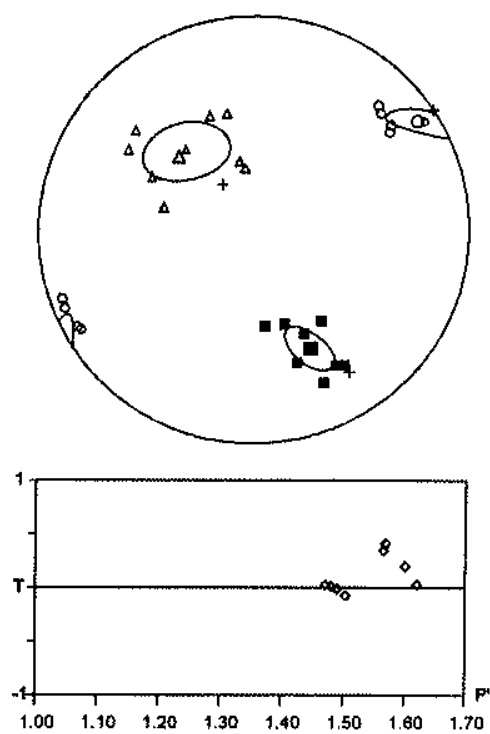

Tensor de Inércia Normalizado

Figura 23. CONT. Projeção estereográfica de Schmid (hemisferio inferior) de dados direcionais de ASM e de trama mineral a partir de cilindros orientados. As elipses representam o desvio padrăo para 1-sigma. 
SITIO 14 (CILINDRO 14A)
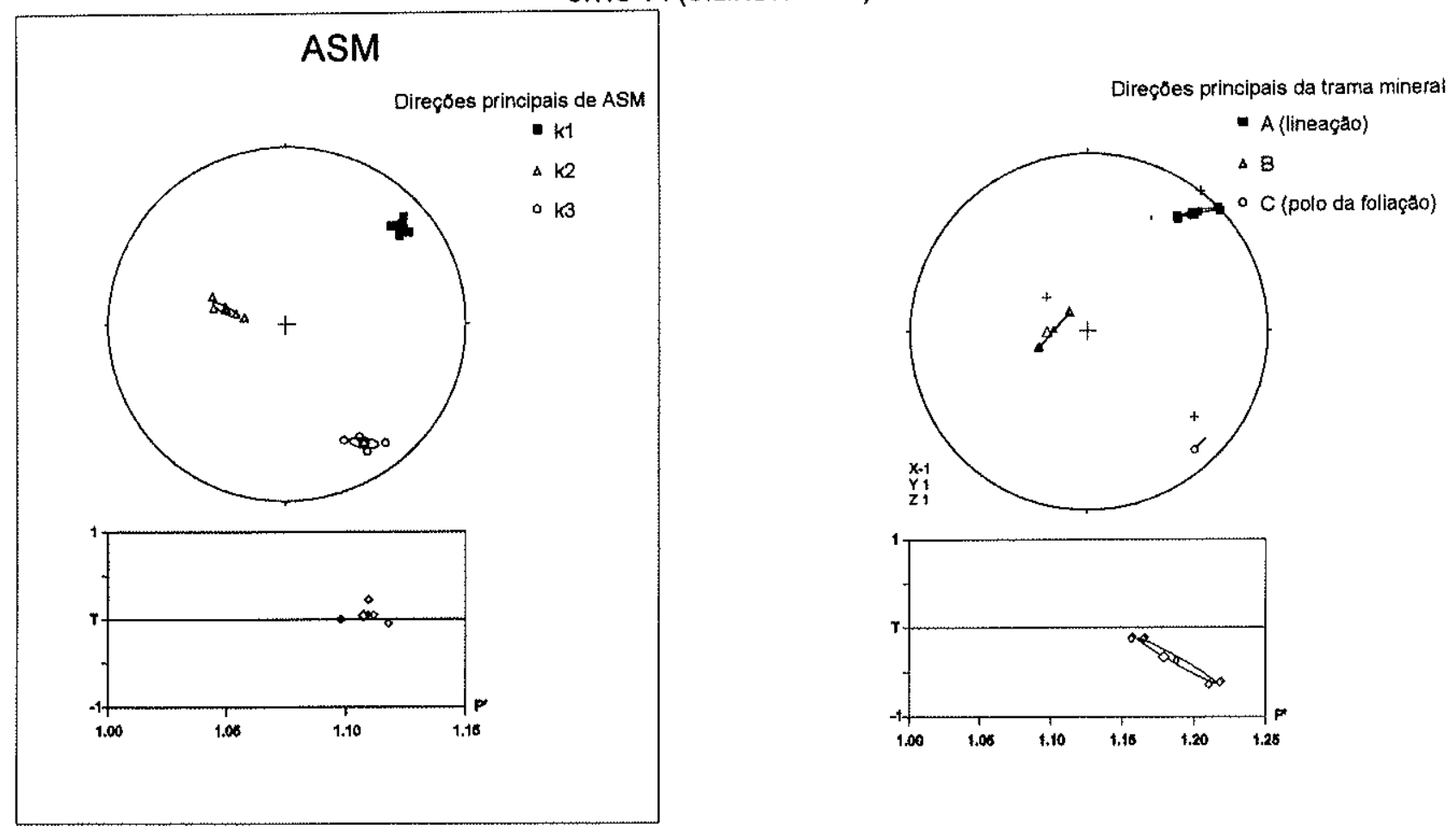

Método de Interceptos

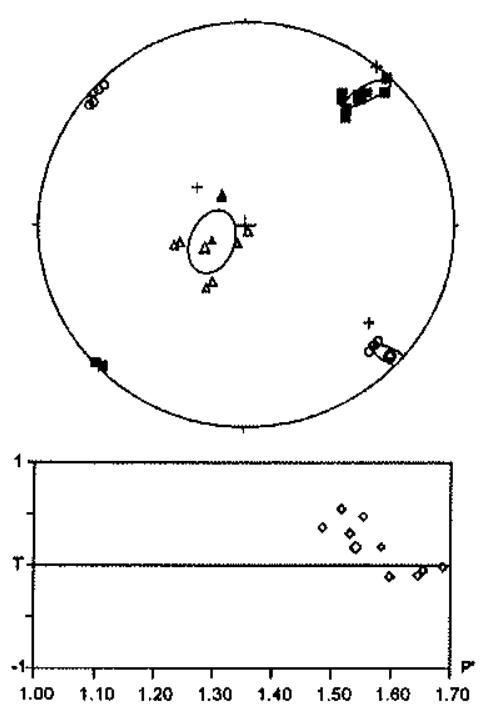

Tensor de Inércia
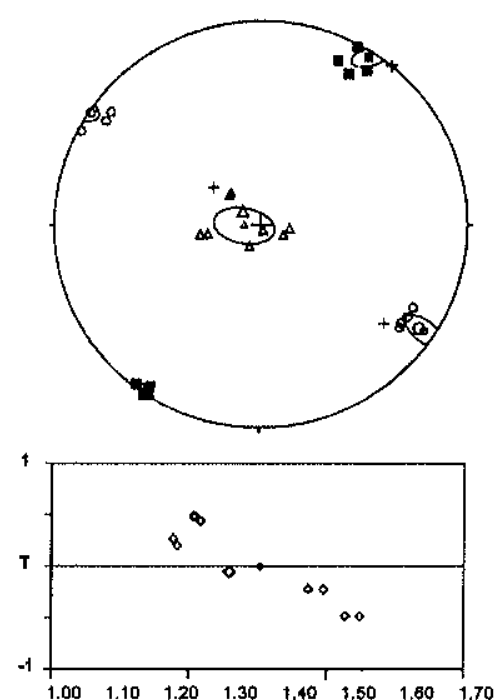

Tensor de Inércia - E

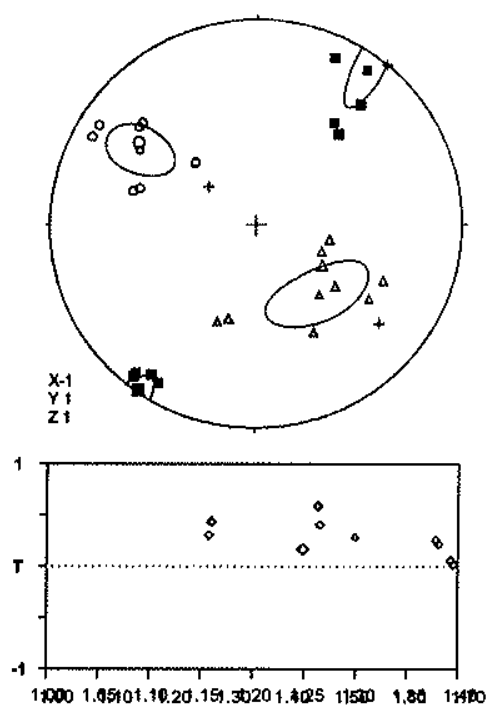

Tensor de Inércia - Normalizado

Figura 23. CONT. Projeçăo estereográfica de Schmid (hemisferio inferior) de dados direcionais de ASM e de trama mineral a partir de cilindros orientados. As elipses representam o desvio padrão para 1-sigma. 


\section{SITIO 15 (CILINDRO 15B)}

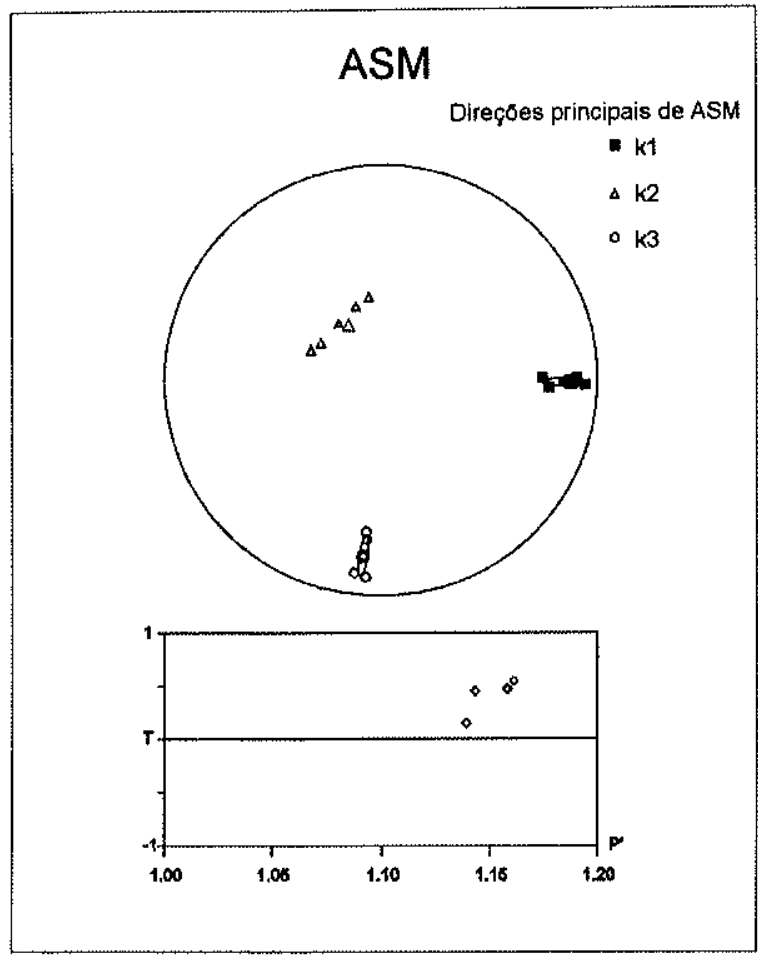

OPF

Direçoes principais da trama mineral
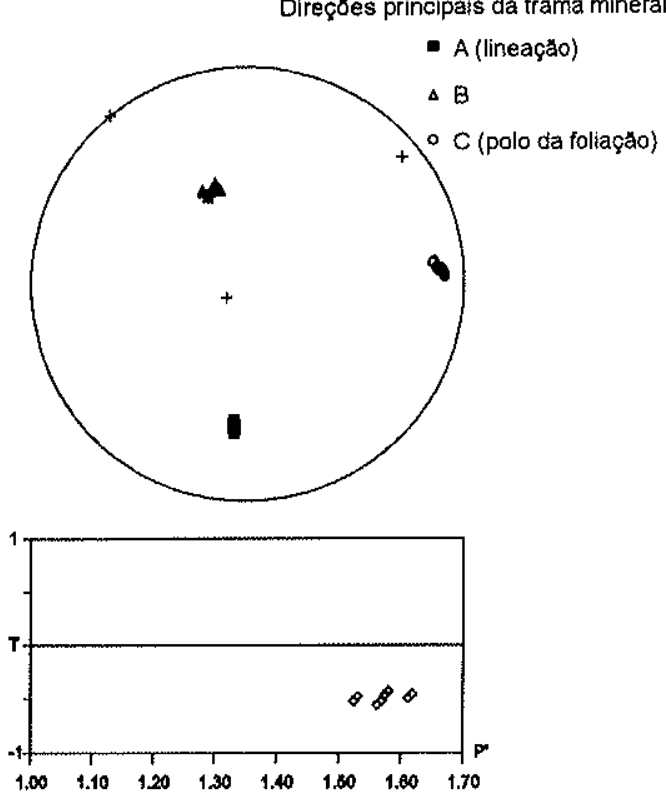

Método de Interceptos
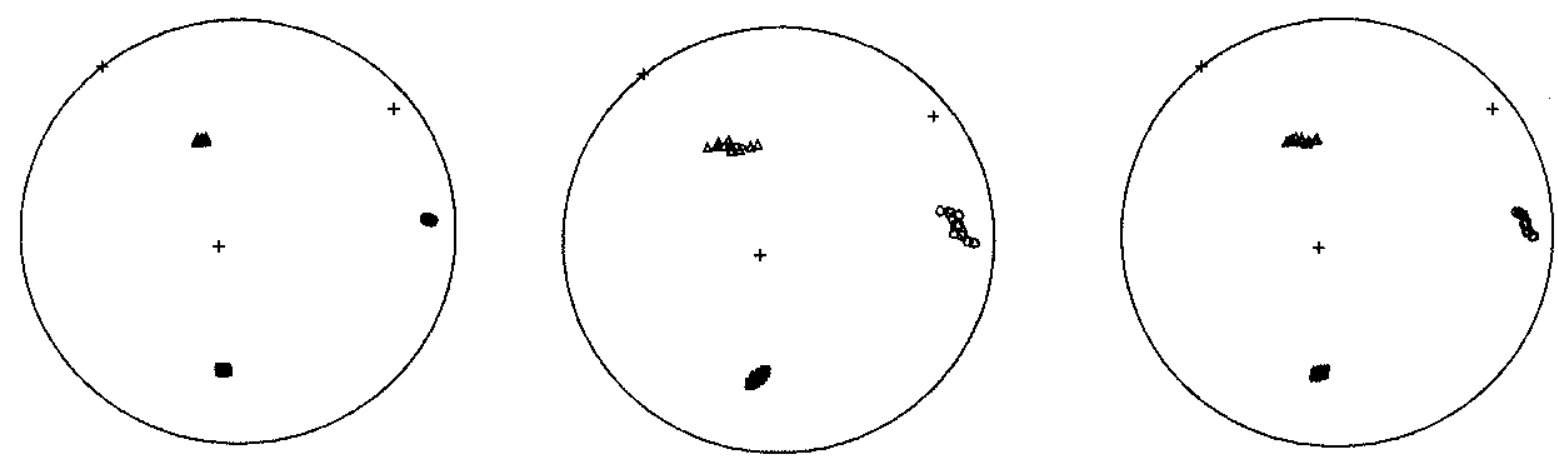

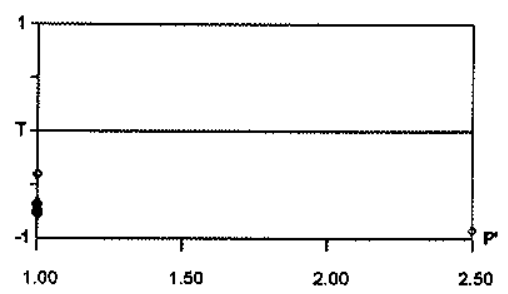

Tensor de Inércia

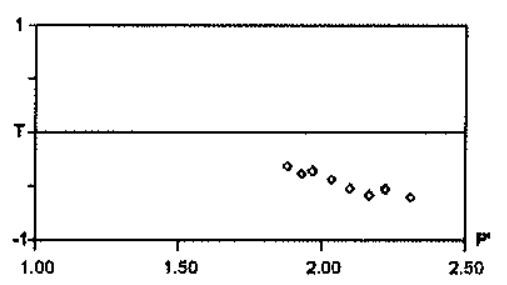

Tensor de Inércia - E

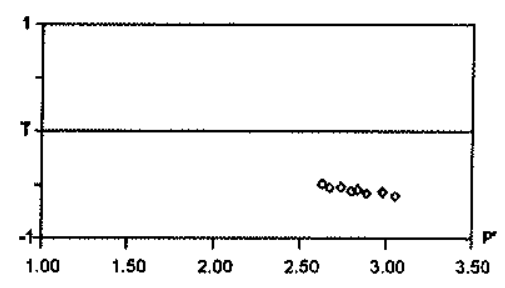

Tensor de Inércia Normalizado

Figura 23. CONT. Projeção estereográfica de Schmid (hemisferio inferior) de dados direcionais de ASM e de trama mineral a partir de cilindros orientados. As elipses representam o desvio padrăo para 1-sigma. 
SITIO 17 (CILINDRO 17b)
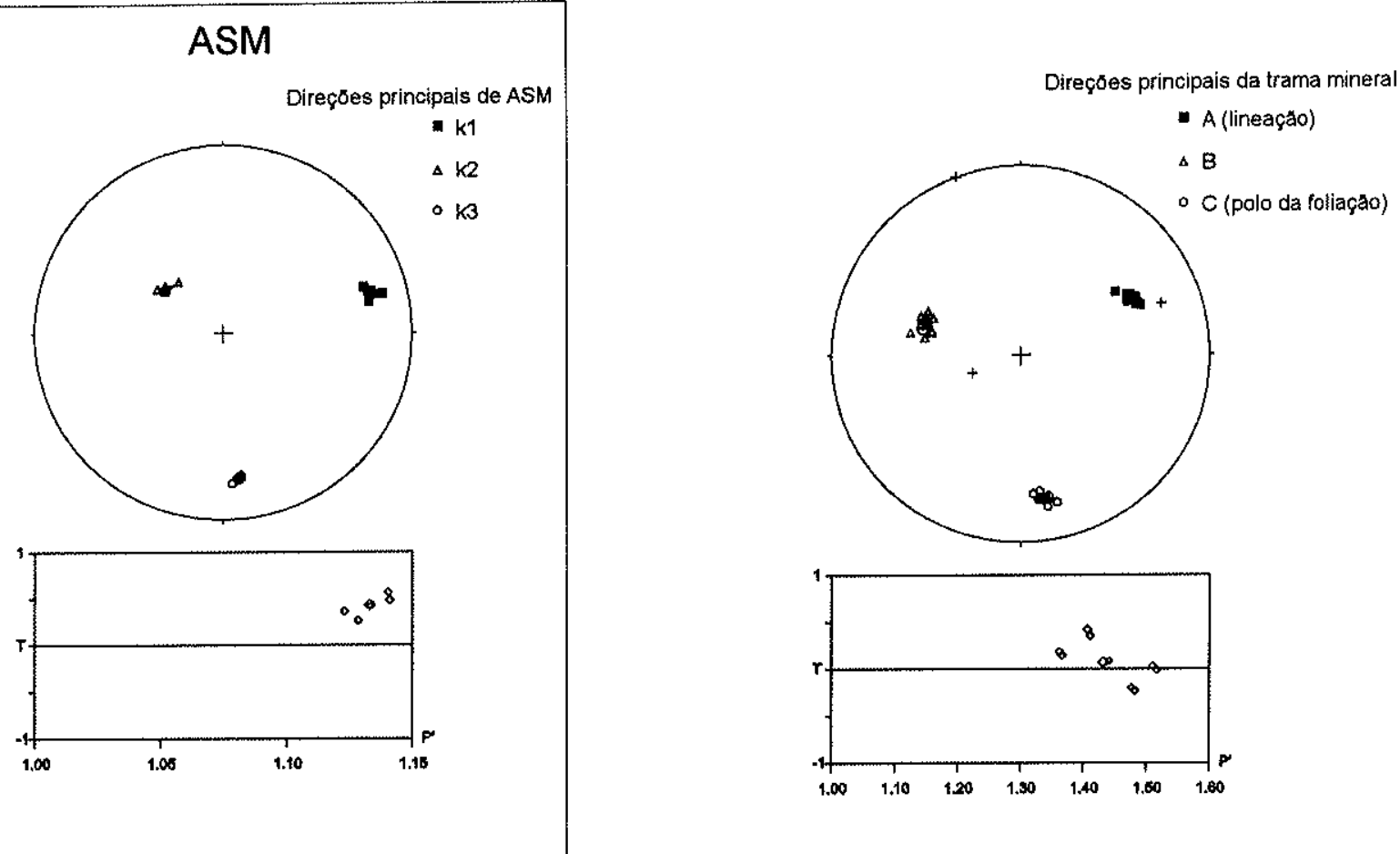

\section{Método de Interceptos}
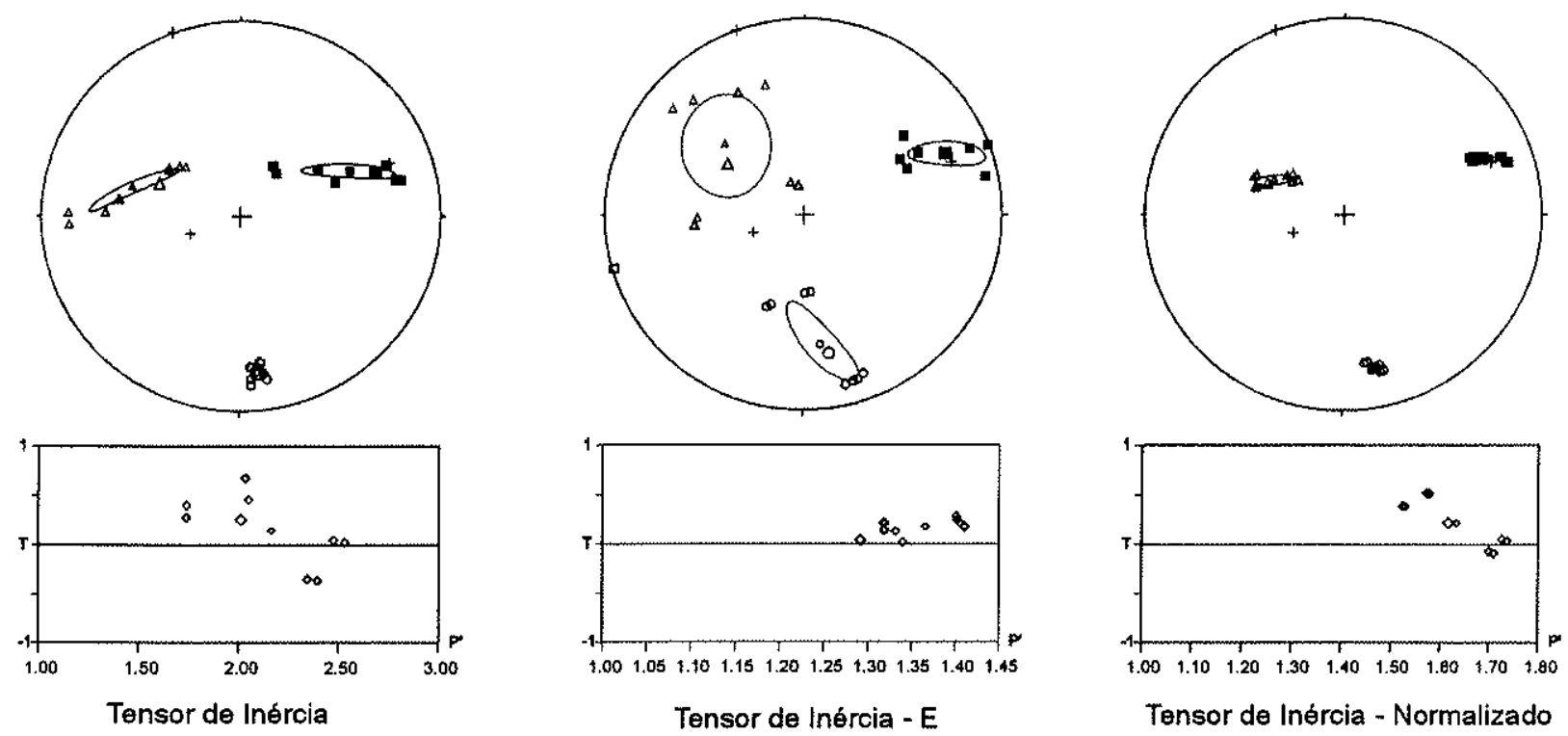

Tensor de Inércia - E

Tensor de Inércia - Normalizado

Figura 23. CONT. Projeção estereográfica de Schmid (hemisferio inferior) de dados direcionais de ASM e de trama mineral a partir de cilindros orientados. As elipses representam o desvio padrão para 1-sigma. 
SITIO 26 (CILINDRO 26A)
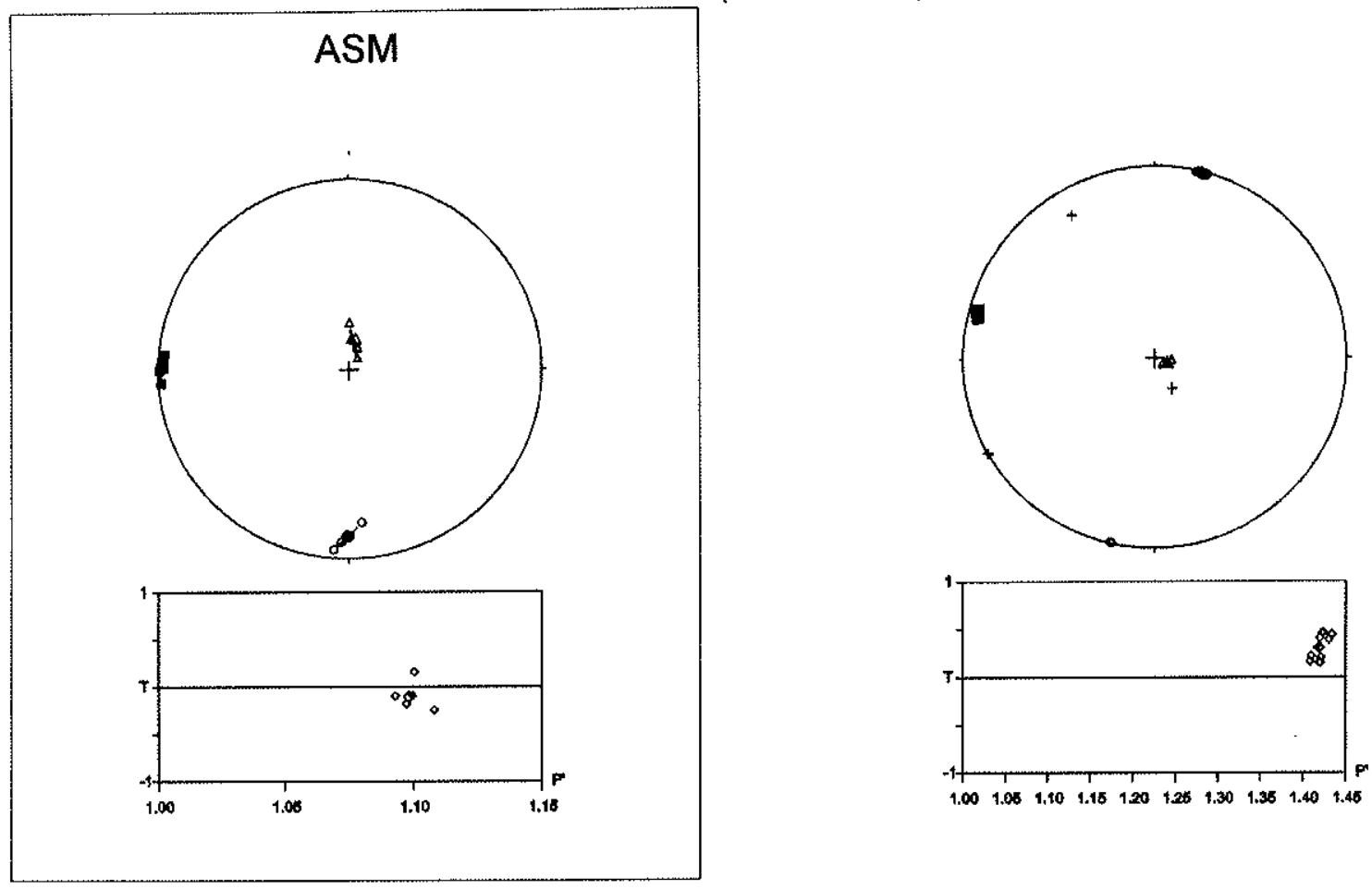

Método de Interceptos
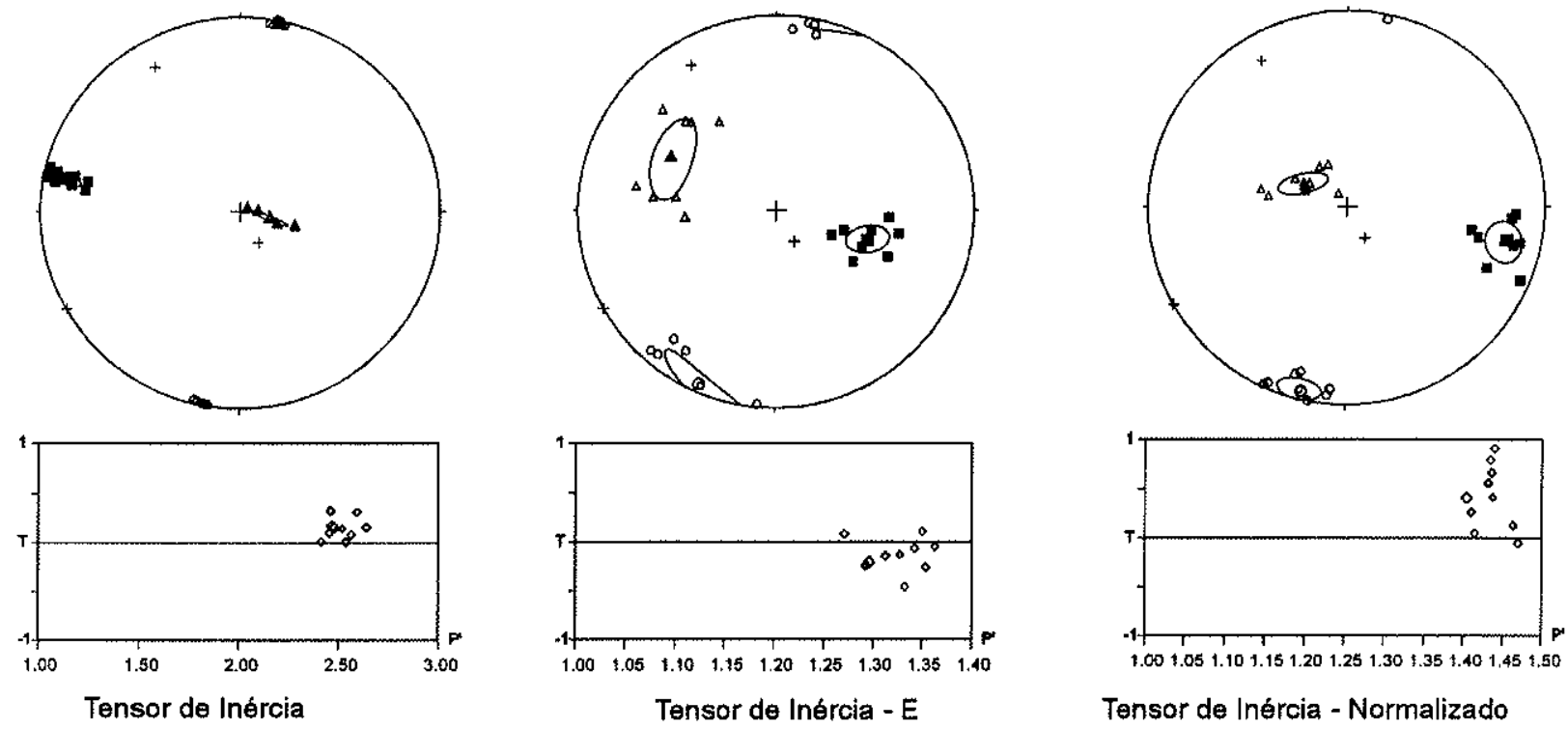

Tensor de Inércia - Normalizado

Figura 23. CONT. Projeçăo estereográfica de Schmid (hemisferio inferior) de dados direcionais de ASM e de trama mineral a partir de cilindros orientados. As elipses representam o desvio padrão para 1-sigma. 
notada tanto pelo método de interceptos como do tensor de inércia (Fig. 23). A lineação magnética aparece em direção NE e NEE com mergulho subhorizontal (máximo a N78/18), registrando os processos de deformação do plutão. Por outro lado, a lineação mineral aparece na direção dominante NW e com mergulho subvertical (máximo a N300/78). O alinhamento de biotita possivelmente retrata o momento da colocação na zona de alimentação. $A$ ASM, por sua vez, independe da trama de biotita. É possivel que pequenas quantidades de magnetita fina neoformada seja responsável pela ASM.

$\mathrm{Na} z o n a$ milonítica, o elipsóide magnético é aparentemente coaxial com o elipsóide da trama mineral (Fig. 23). Portanto, as biotitas aparentemente foram rotacionadas durante a deformaçăo (ou cresceram sendo rotacionadas) até atingir um certo paralelismo com a fábrica deformacional da zona de cisalhamento.

A anisotropia de forma tende a aumentar na direção nordeste para a zona milonítica, registrando possivelmente um maior grau de alinhamento mineral (Fig. 22). A anisotropia média da trama de forma, quando considerados os resultados obtidos por todos os métodos de cálculo, é de $45,3 \%$ ao passo que a ASM tem uma média de $9 \%$. O significado da anisotropia de forma é diferente de ASM. No primeiro caso, a anisotropia reflete os fenômenos magmáticos da colocação do plutão na zona sudoeste, enquanto na zona nordeste reflete os processos deformacionais. Por outro lado, a ASM reflete sempre a trama deformacional e esta não depende exclusivamente da biotita.

O estudo comparativo da OPF com a ASM sugere que o elipsóide magnético é de fato o elipsóide deformacional e pode estar influenciado pela neoformação de magnetita. O elipsóide da trama mineral, por sua vez, registra os processos magmáticos de colocação do plutão na zona sudoeste.

Finalmente, a temporalidade da colocação do plutão e sua relação com a zona de cisalhamento foi determinada através de resultados U-Pb SHRIMP em zircão e Ar-Ar em micas. As idades U-Pb indicam a cristalização do corpo a $234 \pm 4.5 \mathrm{Ma}$ (Fig. 11). Idades plateau em biotita de resfriamento na zona magmática forneceram $229 \pm 1$ e $226 \pm 0.6 \mathrm{Ma}$. Na zona intermediária, idades plateau em muscovita um pouco mais jovens, em torno de $225 \pm 0.9$ e $223,9 \pm 0,5$. Por fim, idades de $221,7 \pm 0,6$ e $221,2 \pm 0,4$ em muscovita e $220,8 \pm 0,4$ e 221,3 $\pm 0,5 \mathrm{Ma}$ em biotita são obtidas na zona milonítica (Figs. $13 \mathrm{e}$ 18). Esta seqüência de idades é sugestiva para uma colocação sin-tectônica 
do corpo e rápido desenvolvimento da deformação simples. As idades mais jovens retratam o final da deformação e sugerem um processo de exumação extremamente rápido do plutão, da ordem de $40-50^{\circ} \mathrm{C} / \mathrm{Ma}$.

Em resumo, pode-se dizer que a ASM do plutão de Marcabelí foi formada concomitante ao desenvolvimento da zona de cisalhamento no Triássico Médio a Superior. Por outro lado, trama mineral registra a ascenção magmática na zona sudoeste, e a deformação cisalhante no extremo nordeste do corpo. $O$ estudo geocronológico corrobora as conclusões obtidas a respeito da colocação sintectônica do plutão de Marcabeli, em relação ao cisalhamento regional desenvolvido num ambiente pós-colisional.

\subsubsection{Comentários sobre a evolução}

Os indicadores geoquímicos e isotópicos apontam derivação por retrabalhamento crustal e variável aporte mantélico para os granitóides fortemente peraluminosos do $\mathrm{CM}$ de El Oro. Os padrões obtidos para a maior parte dos diagramas de Harker não mostram com clareza algum tipo de relação ou agrupamento entre os diversos granitóides do complexo metamórfico, embora o granitóide de Marcabelí apresente o maior valor de $\mathrm{Na}_{2} \mathrm{O}$, contrário aos granitóides de La Bocana que apresentam os valores mais baixos. Já os padrões obtidos pelos ETRs sugerem uma mais notória diferença entre os corpos de La Bocana, La Florida e El Prado com o corpo de Marcabelí que possui a mais baixa concentração destes elementos.

Os granitóides de La Bocana, intimamente relacionados com gnaisses e migmatitos regionais, caracterizados por veios dobrados de quartzo e bolsões de fusão, apresentam os valores mais negativos de $\varepsilon_{\mathrm{Nd}}$ e se situam sobre a linha de mistura teórica obtida entre o extremo crustal e o extremo mantélico considerado. As idades U-Pb obtidas para um granitóide deste grupo fornecem idades U-Pb extremamente coerentes de $232 \mathrm{Ma}$ em sobrecrescimentos magmáticos, que indicariam, além da idade de cristalização do corpo, a idade de migmatização regional e o período mais importante de fusão de material crustal. O plutão de La Florida, embora sua caracteristica distintiva com fenocristais centimétricos de $\mathrm{K}$ feldspato, parece ocasionalmente apresentar relações de gradação com os granitóides de La Bocana. A idade do plutão de La Florida considerada de $239 \mathrm{Ma}$ é similar à anterior dentro do intervalo de erro, mas pode indicar 0 início precoce do magmatismo na área. Os indicadores geoquímicos apresentam uma importante similaridade entre estas 
duas unidades, especialmente no comportamento das ETRs (Fig. 9b). De outro lado, os indicadores isotópicos apresentam algumas diferenças, principalmente nas curvas de evolução de Nd (Fig. 10b), onde os granitóides de La Bocana acusam aporte de material crustal mais evoluído. O plutão de El Prado, embora aparentemente contínuo espacialmente com o plutão de Marcabeli e na mesma posição estrutural (encarte 2), apresenta características geoquímicas e isotópicas similares com o plutão de La Florida.

O plutão de Marcabelí apresenta algumas características particulares. Composicionalmente poderia estar formado por diversos pulsos magmáticos, sendo a parte norte mais granodiorítica e a parte sul com tendência tonalítica. Comparativamente com os outros corpos em estudo, apresenta composições com maior tendência aos campos granodiorítico-tonalítico e a presença de anfibólio como característica notável. Os ETRs sugerem uma diferença apreciável com respeito aos outros granitóides do $\mathrm{CM}$ de $\mathrm{El}$ Oro. Isotopicamente, apresenta os valores de $\varepsilon_{\mathrm{Nd}}$ menos negativos dos granitóides da zona de estudo e a idade modelo mais jovem, sugerindo um aporte mais importante de material juvenil.

O metamorfismo de baixa pressão e alta temperatura descrito para $\circ \mathrm{CM}$ de El Oro, que parece registrar as fases finais da orogenia e o cisalhamento de alta temperatura, como indicado pela presença de fibrolita nos milonitos do plutão de Marcabeli, sugerem um fluxo de calor anômalo elevado na área. Condições de baixa pressão e alta temperatura são normalmente explicados por processos de rifteamento e extensão (Wickham e Oxburgh, 1985) ou por efeitos de contato com intrusões ígneas em niveis crustais intermediários (Lux, et al., 1986). Processos de descompressão num ambiente de extensão têm sido apresentados como modelos orogenéticos adequados para explicar $o$ alto fluxo de calor e extensivo magmatismo presentes numa determinada área (Brown e O'Brien, 1997; Cobbing, 1996; Dewey, 1984). O rápido soergimento das rochas do $\mathrm{CM}$ de El Oro no Triássico Médio a Superior, como evidenciado pelas altas taxas de resfriamento obtidas a partir dos resultados U-Pb em zircão e Ar-Ar em micas, associado a magmatismo fortemente peraluminoso calcio-alcalino alto em $\mathrm{K}$, sugere que $\mathrm{o}$ marco geodinâmico dominante corresponde ao início da extensão regional subseqüente a uma orogenia colisional, onde a fusão das rochas fontes se dá por decompressão após algum engrossamento crustal (Roberts e Clemens, 1993). Neste sentido, os granitóides do $\mathrm{CM}$ de El Oro são pós-tectônicos com relação ao processo 
colisional, mas sintectônicos com relação ao cisalhamento regional produto dos fenômenos extensionais.

O magmatismo e o desenvolvimento do cisalhamento regional são aparentemente concomitantes no Triássico Médio a Superior, resultado da descompressão regional, porém o metamorfismo pode ser um processo de maior duração temporal quando comparado aos processos magmáticos; as evidências encontradas neste estudo não são conclusivas a respeito da idade do metamorfismo. Porém, a grande quantidade de idades em zircões registradas para os granitóides, algumas idades em sobrecrescimento em zircōes dos metassedimentos e uma população muito forte de zircôes no Permo-Triássico registrada na bacia de Talara, noroeste do Peru, de idade Terciaria (Fildani, comunicação escrita), sugerem que o metamorfismo é de idade Permiana.

Parece possível para os granitóides do $\mathrm{CM}$ de El Oro discriminar episódios de magmatismo, embora da mesma idade, de características particulares num espaço geográfico muito limitado. Esta evolução magmática parece compatível com a geração dos granitóides por fusão de material crustal e variável aporte mantélico num ambiente distensivo pós-colisional, sendo que a geração dos granitóides foi impulsionada por atividade mantélica, possivelmente por um processo de rifteamento incipiente. Os diagramas de $\mathrm{CaO} / \mathrm{Na}_{2}$ vs. $\mathrm{Al}_{2} \mathrm{O}_{3} / \mathrm{TiO}_{2}$ de Sylvestre, (1998) (Fig. 24) sugerem uma evolução orogênica de alta temperatura, caracterizada pelas baixas razões de $\mathrm{Al}_{2} \mathrm{O}_{3} / \mathrm{TiO}_{2}$, isto é, com importante aporte mantélico, similar à evolução dos granitóides crustais de Lachlan fold belt (Chapell e White, 1992; Gray et al., 1997; Coney, 1992) e os granitóides Hercinianos peraluminosos da Europa (Rottura et al., 1993; Pamic et al., 1996),

Os granitóides de La Bocana possivelmente representam o extremo de fusão crustal da zona, caracterizando um magmatismo tipo $S$ na região, ao passo que o granitóide de Marcabeli poderia representar um magmatismo por fusão de material ígneo ou crustal com aporte mantélico importante, caracterizando um magmatismo tipo I caledoniano, isto é, magmas mantélicos ou da crosta inferior misturados com magmas de diferentes niveis crustais. A fusão parcial destas rochas crustais ou subcrustais teria sido produzida por descompressão adiabática no levantamento orogênico no tempo em que estas rochas teriam sido rapidamente elevadas em zonas de baixa pressão (Pitcher, 1983). Os granitóides de La Florida e EI Prado podem representar estágios intermediários 

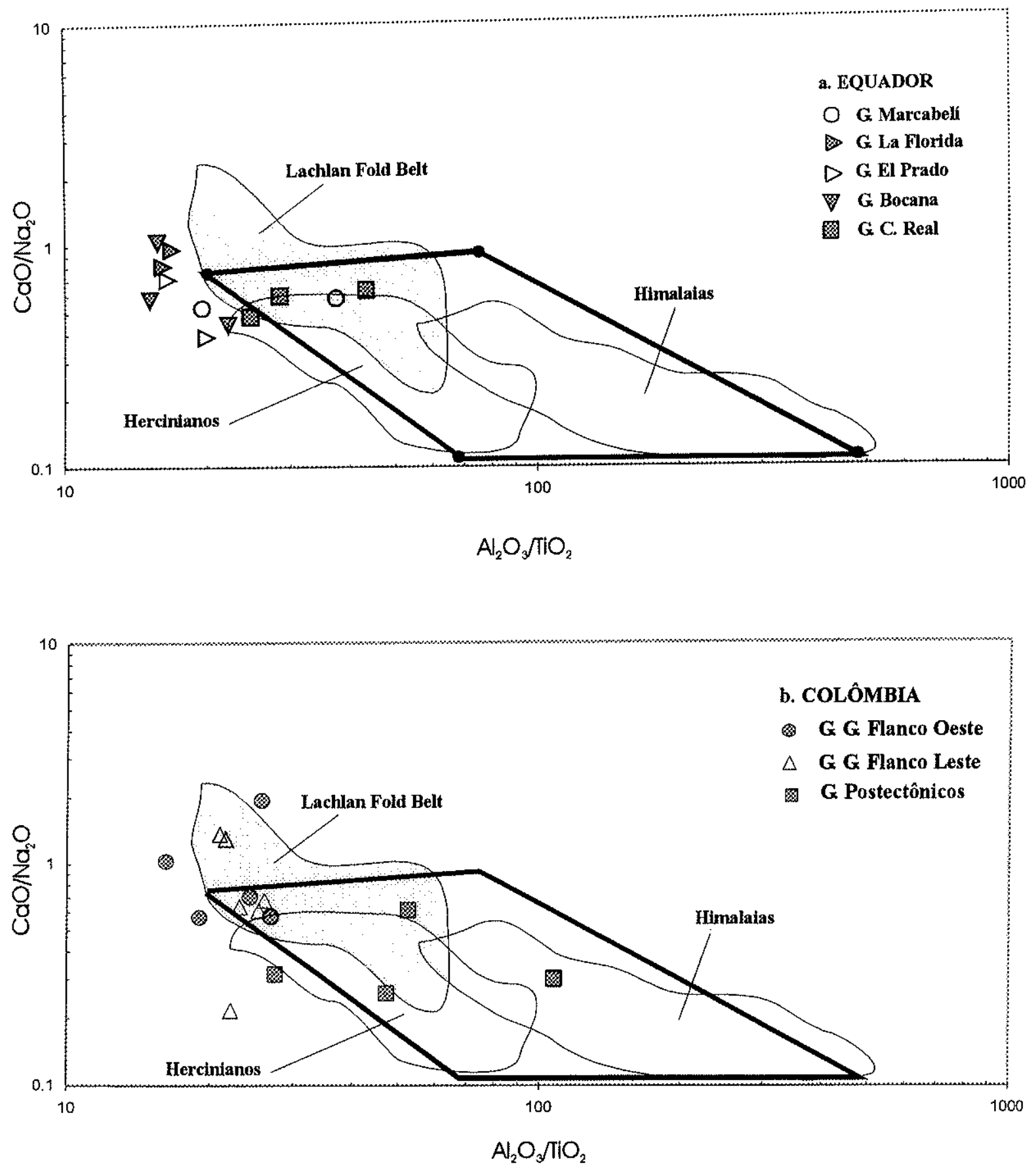

Figura 24. Diagrama de $\mathrm{CaO} / \mathrm{Na}_{2} \mathrm{O}$ vs $\mathrm{Al}_{2} \mathrm{O}_{3} / \mathrm{TiO}_{2}$ para (a) os granitóides do Complexo Metamórfico de El Oro e Cordilheira Real e (b) para os granitos gnáissicos da Cordilheira Central da Colómbia. O campo interior está definido pelos granitóides fortemente peraluminosos definidos por Sylvester (1998). 
na evolução da região. O cenário geral é similar ao apresentado para os granitóides Variscanos de idade Vesiano Superior da Europa Central, isto é, ambiente pós-colisional e magmatismo por underplating (Finger, et al., 1997) num passo transicional de um regime compressivo a um regime distensional (Bonin, 1990), particularmente nos episódios finais de uma orogenia colisional (Barbarin, 1999).

Estabelecer as rochas fonte para estes magmas parece relativamente simples no caso dos granitóides de La Bocana pela íntima associação com os metassedimentos, gnaisses de alto grau e migmatitos, mas é difícil para os outros corpos. A discussão sobre o papel quantitativo dos metassedimentos na geração dos magmas ultrapassa os alcances do trabalho. Uma mistura complexa entre os metassedimentos conhecidos na área e material mantélico poderia explicar apenas parcialmente a distribuição das caracteristicas isotópicas encontradas. Entretanto, os anfibolitos de Piedras (encarte 2), contemporâneos com os granitóides do $\mathrm{CM}$ de El Oro, poderiam representar o material mantélico gerador do calor necessário para a fusão de material crustal.

Estruturalmente, a seqüência metassedimentar apresenta dobras fechadas centimétricas, dobras isoclinais e dobras parasitas em forma de $Z$ e $S$, indicativas de dobramentos regionais isoclinais com plano axial N60-80E/50$70 \mathrm{NW}$, cortadas por cisalhamentos regionais N70E destrais. Indicadores cinemáticos locais sugerem transporte de material para SE durante o desenvolvimento das dobras, provavelmente durante a colisão, cortadas por cisalhamentos destrais desenvolvidos subparalelos aos planos axiais regionais desenvolvidos nos episódios finais orogenéticos, gerando os locais para colocação dos granitóides, o que explica a aparente concordância dos sheets graníticos ao longo do complexo metamórfico. A lineação de estiramento subhorizontal encontrada regionalmente é compativel com uma tectônica fundamentalmente transcorrente no Triássico durante os processos extensionais.

A fábrica magnética do plutão de Marcabeli é concordante com a estrutura regional (Fig. 17), compativel com uma fábrica magnética controlada pelo cisalhamento. A textura mineral estudada em cada sítio de amostragem indicou que a deformação do sheet ocorreu no estágio magmático, e evoluiu progressivamente em direção ao cisalhamento destral para uma textura milonítica. 
A colocação do plutão de Marcabelí é sintectônica e fortemente controlada pelos cisalhamentos regionais, como mostrado pelo estudo de ASM e OPF, ao passo que os outros corpos, aparentemente menos deformados, têm uma relação de campo mais evidente com os metassedimentos que os encaixam, especialmente no caso dos granitóides de La Bocana.

A idade U-Pb SHRIMP em zircão obtida no tonalito de $235 \mathrm{Ma}$ é muito próxima aos valores Ar-Ar obtidos em mica (biotita, muscovita) entre 222 e 226 Ma na mesma unidade. Estes resultados apontam para um resfriamento relativamente rápido da região. Idades $\mathrm{Ar}$-Ar em micas em milonitos da borda do plutão fornecem idades similares às idades de cristalização do corpo, confirmando a sua natureza sintectônica. Os dados combinados indicam claramente que o plutão de Marcabell foi alojado concomitantemente aos eventos tectonomagmáticos triássicos de direção $\mathrm{E}-\mathrm{W}$ registrados no sul do Equador, durante as fases finais do processo orogenético regional.

\subsection{CORDILHEIRA REAL DO EQUADOR}

\subsubsection{Geologia Regional}

A Cordilheira Real é o sistema oriental de duas cadeias montanhosas paralelas que definem os Andes equatorianos. Ao norte, a Cordilheira Ocidental é separada da Cordilheira Real por um vale estrutural denominado depressão interandina, mas, para o sul, os Andes estão representados por uma única cordilheira. Para leste do sistema andino, aparece a denominada zona subandina e o Oriente, que forma parte da bacia Amazônica. Para oeste da cadeia andina, aparecem as planícies da Costa (encarte 1).

A geologia da Cordilheira Real e $0 \mathrm{CM}$ de El Oro foi descrita por Feininger, (1978, 1982, 1987) Aspden et al., (1992a, 1995), Aspden e Litherland (1992) e Eguez e Aspden (1993) e finalmente, uma sintese foi dada por Litherland et al., (1994). A Cordilheira Real forma um cinturão contínuo de uns $650 \mathrm{Kms}$ de rochas metamórficas deformadas, granitóides, migmatitos e rochas sedimentares e vulcânicas. O limite ocidental é definido pela falha Baños-Las Aradas, uma zona de cisalhamento com trend Andino, relacionável à falha de Romeral na Colômbia.

Aspden e Litherland (1992) e Litherland et al. (1994) dividem o Equador em diferentes terrenos litotectônicos. $\mathrm{Na}$ Cordilheira Real aparecem os terrenos 
paleozóicos Loja (encarte 1) e Chaucha de afinidade continental e os terrenos Jurássicos Salado e Alao de afinidade oceânica. No SW de Equador aparece o terreno Amotape (CM de El Oro - encarte 2) com embasamento do Paleozóico e afinidade continental, correlacionável com o terreno Loja da Cordilheira Real (Litherland, et al., 1994). O terreno Loja, que constitui a espinha dorsal da Cordilheira Real, é definido pela associação de rochas metassedimentares semi-pelíticas paleozóicas e os granitóides peraluminosos triássicos Tres Lagunas, relacionados a ortognaisses e migmatitos da unidade Sabanillas (encarte 1) e consistem principalmente de biotita-granada-muscovita monzogranitos.

As rochas metassedimentares paleozóicas são agrupadas nas unidades Chiguinda e Agoyán, compostas respectivamente por quartzitos e filitos negros, formando uma seqüência semi-pelítica e granada-muscovita xistos, além de gnaisses com idades entre o Devoniano e o Permiano. Existe uma ausência geral de rochas verdes ou de afinidade vulcânica nestas seqüências. O grau metamórfico é baixo a médio e as rochas apresentam evidências de polimetamorfismo. Estas unidades apresentam afinidades continentais depositadas num ambiente de margem passiva (Litherland et al., 1994).

Os granitos Tres Lagunas são a principal unidade ígnea do terreno Loja (encarte 1). Segundo Litherland et al. (1994), estão associados com os metassedimentos das unidades Chiguinda e Agoyán ao longo da cordilheira, e formam desde corpos batolíticos até lentes de poucos centímetros. Os granitóides são de tamanho de grão médio a grosso e possuem megacristais de K-feldspato de até $14 \mathrm{~cm}$. quando observados não deformados. Os granitóides apresentam também cristais de quartzo azul, característica distintiva em campo. Composicionalmente, as rochas correspondem a monzogranitos e granodioritos sem associações básicas (Litherland, et al., 1994). A granada é um acessório comum e alcança até $30 \%$ localmente; cordierita e muscovita têm sido observadas, embora em pouca quantidade. $O$ granito apresenta normalmente evidências de deformação, metamorfismo e recristalização com formação de texturas gnáissicas e miloníticas. As rochas mais comuns são granitos foliados e augen-gnaisses (Litherland, et al., 1994).

A unidade de Sabanillas (encarte 1), corresponde a um conjunto de orto e paragnaisses de médio a alto grau de metamorfismo. A unidade corresponde a quartzitos gnáissicos com silimanita, muscovita e biotita que gradam a ortognaisses granodioríticos com muscovita. Estão presentes também 
gnaisses migmatíticos e gnaisses biotíticos com sillimanita e cianita. São observadas associações de alto grau com silimanita-biotita-quartzo-albita e cianita-biotita-ortoclásio-quartzo. Estas rochas seriam originalmente granodioritos associados a sedimentos pelíticos metamorfizados a gnaisses de médio a alto grau (Litherland et al., 1994).

\subsubsection{Geologia isotópica}

A amostragem feita nas rochas intrusivas permianas da Cordilheira Real foi extremamente limitada e tem por objetivo apenas obter pontos de correlação regional tanto com as rochas do $\mathrm{CM}$ de El Oro quanto com as rochas da Cordilheira Central da Colômbia. Foram obtidas análises para três amostras correspondentes ao denominado granitóide Três Lagunas na parte norte da cadeia perto da cidade de Papallacta e perto da cidade de Baños e uma amostra no sul para o denominado gnaisse de Sabanillas (encarte 1).

O gnaisse de Sabanillas fornece uma razão inicial de ${ }^{87} \mathrm{Sr}-{ }^{86} \mathrm{Sr}$ para $230 \mathrm{Ma}$ de 0,711 , valor similar aos valores obtidos para as rochas do $\mathrm{CM}$ de El Oro e da Cordilheira Central da Colômbia. Os valores de $\mathrm{Sr}$ para as outras duas amostras do granitóide de Três Lagunas são 54 e 34 ppm, portanto fora do intervalo de confiança recomendado pelo CPGeo-USP para cálculo da razão inicial de $\mathrm{Sr}$ por causa da falta de precisão no cálculo da razão ${ }^{87} \mathrm{Rb}-{ }^{86} \mathrm{Sr}$.

Os valores de $\mathrm{Nd}$ para as amostras em estudo variam num intervalo estreito entre $-4,8$ e $-6,1$, valores similares aos obtidos para as outras zonas em estudo.

Na figura 36 , de $\varepsilon_{(\mathrm{Nad})}$ vs. $\varepsilon_{(\mathrm{Sr}) \text {, }}$ calculados ao presente (0), observa-se uma distribuição das amostras como uma ampla variação dos valores $\varepsilon_{\mathrm{Sr}}$ enquanto os valores de $\mathrm{Nd}$ permanecem muito similares. O campo das rochas da Corditheira Real consideradas se sobrepõe perfeitamente ao campo de rochas granitóides do $\mathrm{CM}$ de El Oro do ponto de vista isotópico. As amostras situamse inteiramente no quadrante IV do diagrama $\varepsilon_{(\mathbb{N d})}$ vs. $\varepsilon_{(\mathrm{Sr}) \text {, indicativo de uma }}$ proveniência fundamentalmente crustal. As idades modelo variam num estreito intervalo entre 1,41 e 1,50 Ga, compatível com as idades modelo obtidas para as rochas da província de El Oro. 


\subsubsection{Geocronologia}

Anterior ao convênio bilateral do BGS e a CODIGEM do Equador (1986-1993), a geocronologia disponivel no Equador consistia de datações K-Ar de metassedimentos da Cordilheira Real que forneceram idades exclusivamente cretácicas (Herbert e Pichler, 1983 -em Litherland et al., 1994-; Hall e Calle, 1982; Baldock, 1982 e Kennerly, 1982) e datações K-Ar de granitóides que forneceram idades desde o Jurássico até o Terciário (Kennerly, 1980; Herbert e Pichler, 1983 em Litherland et al., 1994).

Aspden et al. (1992b), dentro do convênio bilateral mencionado, realizaram cerca de 150 datações radiométricas tanto na Cordilheira Real quanto na província de El Oro pelos métodos $\mathrm{K}-\mathrm{Ar}$ e $\mathrm{Sm}$-Nd para determinar a idade do metamorfismo, $e$ isócronas $\mathrm{Rb}$-Sr para determinar a idade de cristalização dos corpos plutônicos. $O$ encarte 8 apresenta as idades mais relevantes a respeito da evolução Permo-Triássica da região. Idade Isócrona $\mathrm{Rb}-\mathrm{Sr}$ no ortognaisse de Sabanillas, na parte sul da Cordilheira Real, forneceu uma idade de $224 \pm 37$ $\mathrm{Ma}$ interpretada como a idade de metamorfismo (Aspden et al., 1992b). Na parte norte da cordilheira, idades K-Ar em anfibolitos, gnaisses e xistos não forneceram idades consideradas analiticamente aceitáveis (Aspden et al., 1992b). Todas as idades obtidas para orto e para gnaisses da unidade Sabanillas forneceram idades do Cretácico Superior interpretadas como de rejuvenescimento isotópico (Apsden et al., 1992b). Idades Sm-Nd na parte norte da cordilheira não forneceram idades com valor interpretativo (Aspden et al., 1992b). Idades isócronas $\mathrm{Rb}-\mathrm{Sr}$ para os granitóides Tres Lagunas forneceram idades mínimas de $200 \pm 12 \mathrm{Ma}$ (Aspden et al.,1992b). Idades jurássicas e cenozóicas são reportadas para outros corpos ígneos da Cordilheira Real (Aspden et al., 1992b).

Noble et al. (1997) obtiveram idades U-Pb em monazita de granitóides e gabros metamorfoseados da Cordilheira Real e do CM de El Oro, com a finalidade de estudar a história magmática pré-cretácica do embasamento dos Andes do Norte. Na Cordilheira Real, o batólito Tres Lagunas forneceu uma idade de $227,3 \pm 2.2 \mathrm{Ma}$, idade muito similar às obtidas para o granito de Marcabelí e Limón Playa de 227,5 \pm 0.8 e $200 \pm 30$ respectivamente e o intrusivo máfico Piedras de $221 \pm 18$ Ma no CM de El Oro (Noble et al., 1997).

As idades Ar-Ar obtidas para três amostras da Cordilheira Real do Equador durante a presente pesquisa forneceram idades do Cretácico Superior (Fig. 

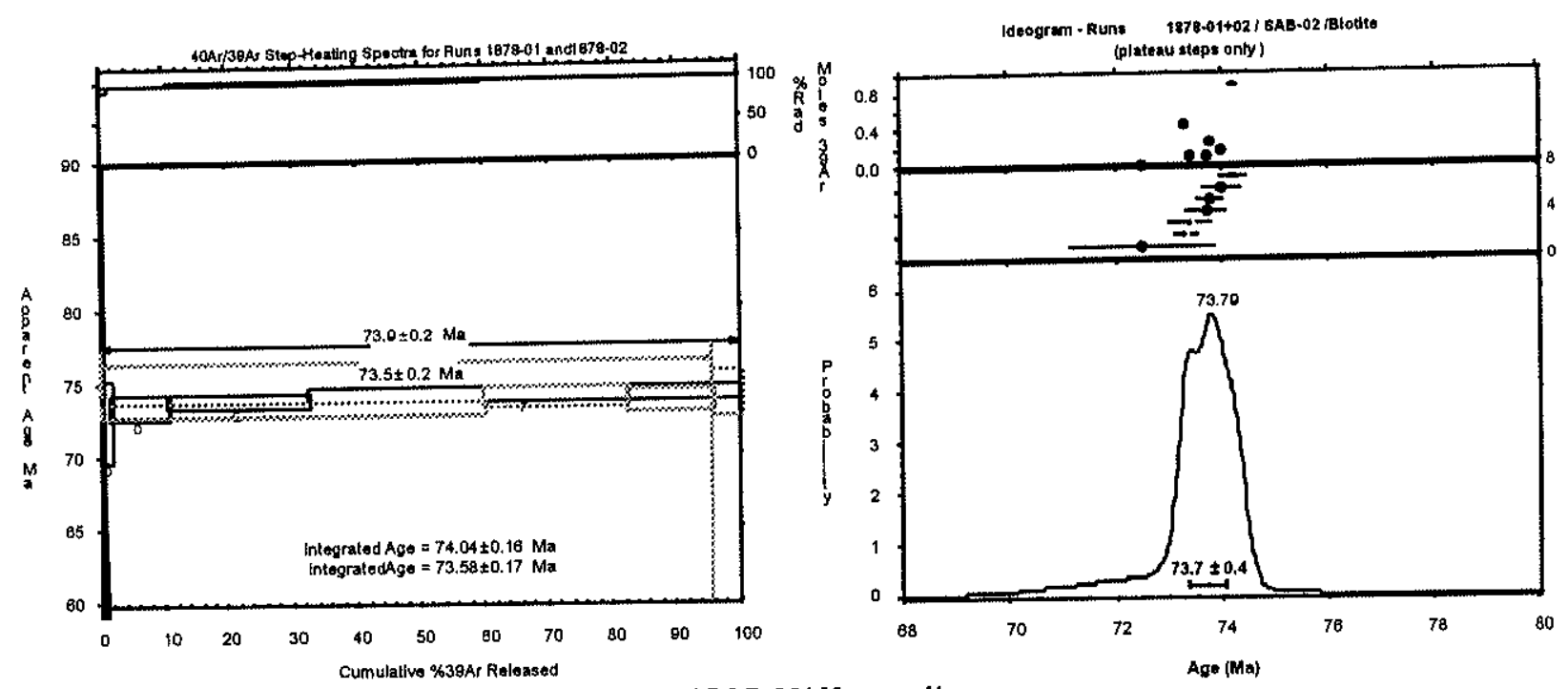

1879 / PAP-03/ Muscovite
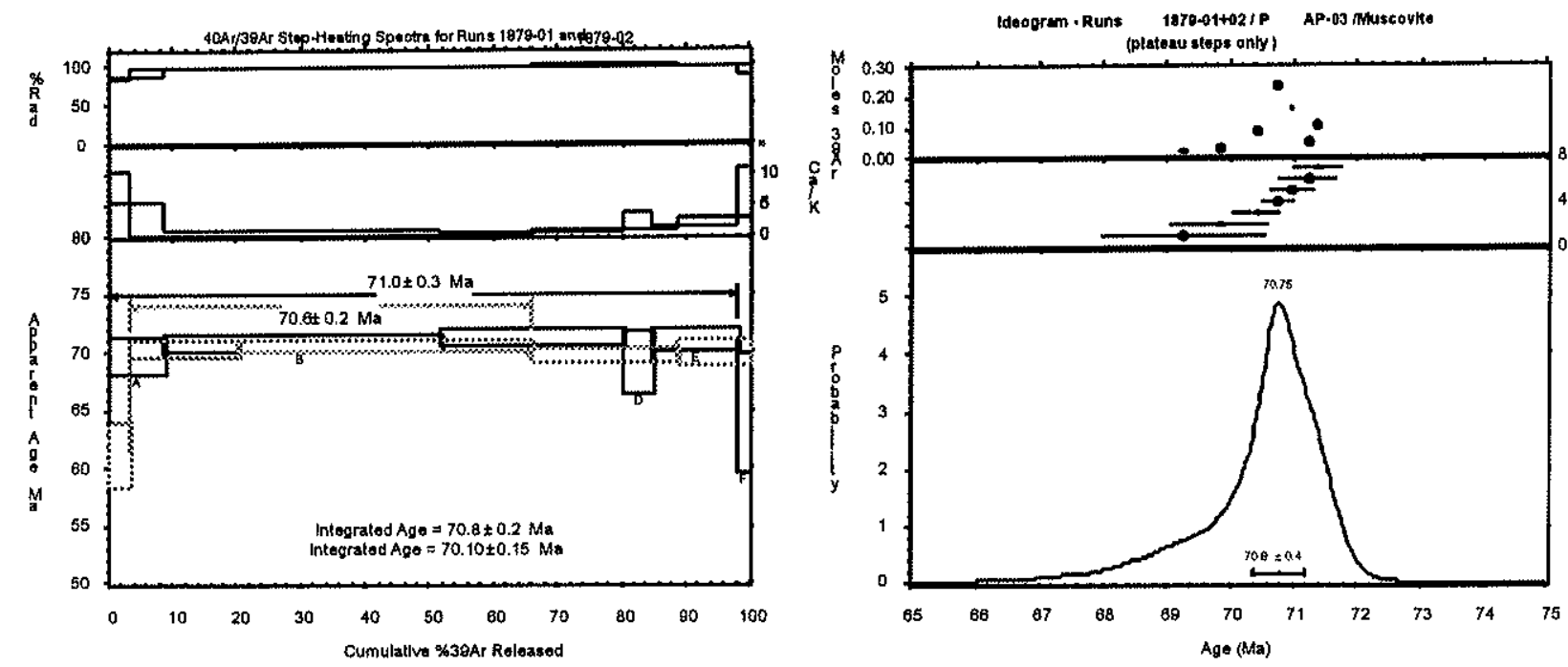

1895 / BA-03 / Biotite

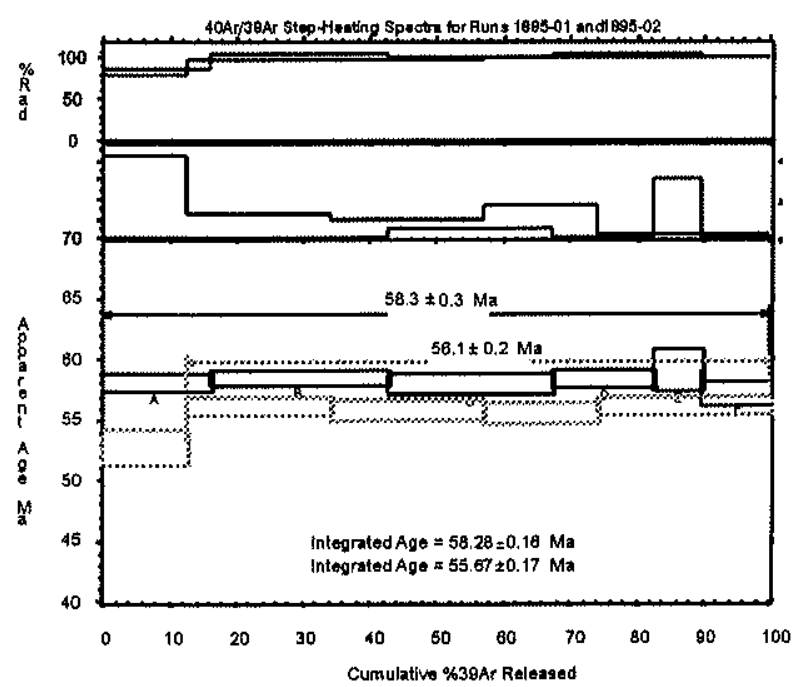

Figura 25. Espectros de Ar-Ar para o Gnáisse de Sabanillas (SAB) e granitóide de Três Lagunas em Baños (BA) e Papallacta (PAP). 
25), registrando apenas o aquecimento conhecido nesta época em toda a região. A amostra coletada para o denominado granitóide de Três Lagunas, perto da cidade de Papallacta na parte norte da cadeia, forneceu uma idade Ar-Ar plateau de $71 \pm 0,3$ e 70,6 $\pm 0,2 \mathrm{Ma}$; outra amostra coletada na parte meridional da cadeia perto da cidade de Baños forneceu idade plateau de $58,3 \pm 0,3 \mathrm{Ma}$ e $56,1 \pm 0,2 \mathrm{Ma}$. A diferença nos resultados é desconhecida, mas as idades são interpretadas como de rejuvenescimento isotópico. Finalmente uma amostra coletada na parte sul da cadeia no Equador para o denominado

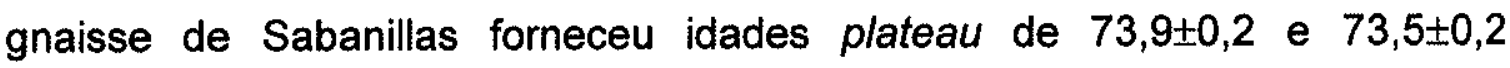
similares às obtidas para a parte norte. A ampla distribuição geográfica da área não permite obter uma conclusão precisa do significado destas idades e as possiveis correlaçoes regionais, mas idades obtidas em trabalhos anteriores mostram que a idade de formação destas rochas é Triássica (Noble et al., 1997; Litherlhand et al., 1994).

\subsection{CORDILHEIRA CENTRAL DA COLÓMBIA}

\subsubsection{Geologia Regional}

A parte setentrional da Cordilheira Central da Colômbia é composta por blocos crustais de naturezas e idades diversas, resultado de uma complexa evolução geológica que inclui aglutinação de terrenos suspeitos, polimetamorfismo, magmatismo cálcio-alcalino cretácico, extensiva deformação, fenômenos regionais de dispersão (González, 2000; Toussaint, 1993; Maya e González, 1995) e magmatismo peraluminoso permo-triássico.

O embasamento continental da Cordilheira Central compreende um núcleo polimetamórfico pré-Mesozóico (encarte 3) (Restrepo e Toussaint, 1982), composto principalmente por metassedimentos e metamorfitas de baixo a médio grau do Complexo Cajamarca (Maya e González, 1995), rochas de alto grau da zona de El Retiro, metamorfitas de alto grau do Complexo de Puquí (González, 2000) e diques de gabros metamorfizados (González, 2000; Correa e Martens, 2000). O complexo Cajamarca corresponde a rochas nas fácies xisto verde a anfibolito e a paragênese reportada indica condições metamórficas de baixa pressão (González, 2000).

- Complexo Cajamarca inclui xistos pelíticos, quartzitos, mármores e anfibolitos, enquanto as rochas da zona de El Retiro incluem migmatitos, localmente granulitos básicos e ácidos, anfibolitos, gnaisses, xistos biotíticos e 
silimaníticos e rochas granitóides deformadas (González, 2000; Ordoñez, 1997). Este embasamento é intrudido por granitos gnáissicos paleozóicos e permianos, stocks graníticos triássicos, batólitos cretácicos e se encontra recoberto por rochas de arcos vulcânicos continentais (González et al., 1988; Restrepo y Toussaint, 1982).

Esta parte da cadeia andina tem sido tradicionalmente descrita como um terreno suspeito, isto é, terreno Tahami (Restrepo e Toussaint, 1988), afetado por vários episódios tectono-metamórficos durante o Devoniano-Carbonífero, 0 Permo-Triássico e o Cretácico (Restrepo et al., 1991). Possiveis eventos do Paleozóico Inferior ou ainda pré-Cambrianos também têm sido propostos (Hall et al., 1972; González, 1980; Restrepo e Toussaint, 1984).

A idade da seqüência metamórfica de baixo a médio grau de metamorfismo do Complexo Cajamarca na parte setentrional da cordilheira obtida para rochas do Grupo Ancón é 270 110 (K-Ar em biotita) (Restrepo et al., 1978). A idade mínima da seqüência metamórfica de alto grau foi inicialmente obtida a partir do gnaisse de Pescadero que intrude os metassedimentos do Grupo Valdivia e tem sido datado a $253 \pm 10 \mathrm{Ma}$ (Restrepo et al., 1991) (Isócrona $\mathrm{Rb}-\mathrm{Sr}$ rocha total). Outras idades neste intervalo são de $254 \pm 10$ (K/Ar em biotita) (Toussaint et al., 1978) e 285 $\pm 12 \mathrm{Ma}$ (Restrepo et al., 1991) obtidas para o gnaisse de Puquí. Granada anfibolitos pertencentes ao Complexo Cajamarca estão intrudidos pelo gnaisse de La Miel (Sepúlveda e Saldarriaga, 1980). Este ortognaisse tem uma idade U-Pb de cerca de $400 \mathrm{Ma}$ (Fig. 32) e uma idade $\mathrm{Rb}-\mathrm{Sr}$ isócrona de 388 $\pm 12 \mathrm{Ma}$ (Restrepo et al., 1991). A idade do metamorfismo da Cordilheira Central de Colômbia pode ser Paleozóico Inferior como sugerido pela idade de cristalização do gnaisse de La Miel, mas um metamorfismo permiano parece estar bem documentado.

Restrepo et al., (1991) sugerem uma idade Caledoniana para o metamorfismo da Corditheira Central, baseados numa idade isocrônica $\mathrm{Rb}-\mathrm{Sr}$ devoniana e duas idades $\mathrm{K}$-Ar pensilvanianas obtidas para o gnaisse de La Miel. Um metamorfismo permo-triássico está sugerido por idades $\mathrm{K}$-Ar em micas e Rb-Sr em rochas do Complexo Cajamarca (Hall et al., 1972; González, 1980; Vesga e Barrero, 1978; Toussaint et al., 1978; Restrepo et al., 1991). O intervalo amplo de idades que aparece na literatura não tem uma explicação clara, sendo que poderia se tratar de reaquecimentos produzidos por stocks cretácicos (Restrepo et al., 1991) ou por um alto fluxo de calor ao longo de todo o período Permo-Triássico. 
Idades K-Ar e Ar-Ar obtidas para os gnaisses graníticos da Cordilheira Central da Colômbia fornecem idades principalmente triássicas (Vesga e Barrero, 1978; González, 1980; Vinasco, 2001), reflexo do alto fluxo de calor e migmatização regional. Idades U-Pb SHRIMP em zircão no intervalo 250-280 Ma podem estar provavelmente mostrando as idades de cristalização destes corpos magmáticos e uma idade triássica superior $\mathrm{U}-\mathrm{Pb}$ apresentada por Ordoñez (2001) para um leucogranito pode representar a época de migmatização regional registrada também no sistema K-Ar.

$\mathrm{Na}$ Cordilheira Central têm sido obtidas idades K-Ar entre 120 e $80 \mathrm{Ma}$ em rochas metamórficas, interpretadas como de um metamorfismo cretácico (Brook, 1984, McCourt et al., 1984, Restrepo et al., 1991). Idades K-Ar entre 90 e $60 \mathrm{Ma}$ foram obtidas para o Batólito Antioqueño e rochas magmáticas associadas que marcariam a presença de evento de arco magmático cretácico na Cordilheira Central. No Cenozóico não existem evidências de metamorfismo na Cordilheira Central e o principal fenômeno geológico foi a deposição dos sedimentos da Formaçăo Amagá e uma importante discordância miocênica. $O$ magmatismo está restrito principalmente à Cordilheira Ocidental e ao graben Cauca-Patía no Mioceno.

\section{Rochas em estudo}

O conjunto de rochas com evolução permo-triássica na Cordilheira Central colombiana compreende principalmente ortognaisses tradicionalmente conhecidos como "intrusivos gnáissicos" devido à sua aparência (Feininger et al., 1972). Vários batólitos têm sido agrupados dentro desta unidade e incluem os granitóides gnáissicos de Naranjales, Norcasia-San Diego, Río Verde e Samaná no flanco leste da cordilheira e os granitos gnáissicos e granitóides de Manizales, Pácora, Pantanillo, Palmas, Palmitas, Montegrande, Horizontes e Pescadero no flanco ocidental da cordilheira (González, 1980, 2000; Restrepo, 1986; Restrepo et al., 1989, 1991; Toussaint, 1993). No flanco oeste da cordilheira aparecem também os stocks graníticos triássicos de la Honda e El Buey, de natureza pós-tectônica, que intrudem rochas do Complexo Cajamarca (González, 1980) (encarte 3).

Os granitos gnáissicos escolhidos para as correlações regionais são amostras dos granitóides do Rio Verde e Samaná no flanco leste da cordilheira e os granitóides de Manizales, La Miel, Palmitas, Horizontes e o gnaisse de Abejorral do flanco oeste (encarte 3). 
As amostras são compostas principalmente por plagioclásio, K-feldspato, quartzo, biotita e muscovita. As amostras de Río Verde e Samaná contêm cordierita e o gnaisse de Abejorral contém sillimanita. Minerais secundários incluem clorita e muscovita e a quebra de plagioclásio a saussurita é comum. Minerais acessórios são zircão, apatita, titanita e opacos. Texturalmente, as amostras variam de grão médio a grosso, com textura granítica-gnáissica e porfirítica. Nos ortognaisses de Samaná e Abejorral, têm sido descritos xenólitos de xistos micáceos (Cossio e Viana, 1986; Gonzalez, 1980), possivelmente das encaixantes pertencentes ao Complexo Cajamarca. $O$ plagioclásio é normalmente o mineral de maior tamanho, encontra-se desde $70 \%$ no granito gnáissico de Horizontes até $6 \%$ no gnaisse de Abejorral. Kfeldspato não está presente em todas as amostras, mas pode atingir até $24 \%$ no granito gnáissico de Samaná. O quartzo varia de $56 \%$ no gnaisse de Abejorral a $20 \%$ no granito gnáissico de Horizontes. A biotita varia de $23 \%$ no granito gnáissico de Palmitas até $8 \%$ no granito gnáissico de Horizontes. Esta é a principal fase máfica é se encontra tipicamente de cor vermelho. A muscovita está presente em todas as amostras bem cristalizada e formando a foliação ou gnaissificação, porém se encontra também como sericita substituindo corierita (?) e K-feldspato. Deformação no estado sólido é fato comum nestas rochas, mas de grau variável. As texturas de deformação incluem redução do tamanho de grão, micas com extinção ondulosa, geminação do microclínio, formação de mirmekita e pertitas (flame pertite).

Os stocks graníticos de Amagá e La Honda são clasificados petrograficamente como granodioritos. O stock granítico de La Honda é composto principalmente por quartzo, K-feldspato e plagioclásio com textura granítica, embora com alguma deformação sobreimposta. O plagioclásio, de composição oligoclásio, varia entre $20-60 \%$, K-feldspato entre $2-35 \%$, quartzo normalmente aparece em $30 \%$ e biotita entre 1 e $20 \%$. Fibrolita intersticila e cordierita estã presentes. Acessórios comuns são allanita e zircão, apatito, esfena e epidoto.

\subsubsection{Geoquímica de elementos maiores, traço e ETR.}

16 amostras foram analisadas para elementos maiores e traço e 14 amostras para elementos de terras raras (ETR) (encarte 6). Baseado no cálculo normativo, os granitos gnáissicos do flanco leste da corditheira situam-se com tendência ao campo dos monzogranitos, ao passo que os granitos gnáissicos do flanco oeste situam-se com tendência ao campo dos granodioritos (Fig. 26). 


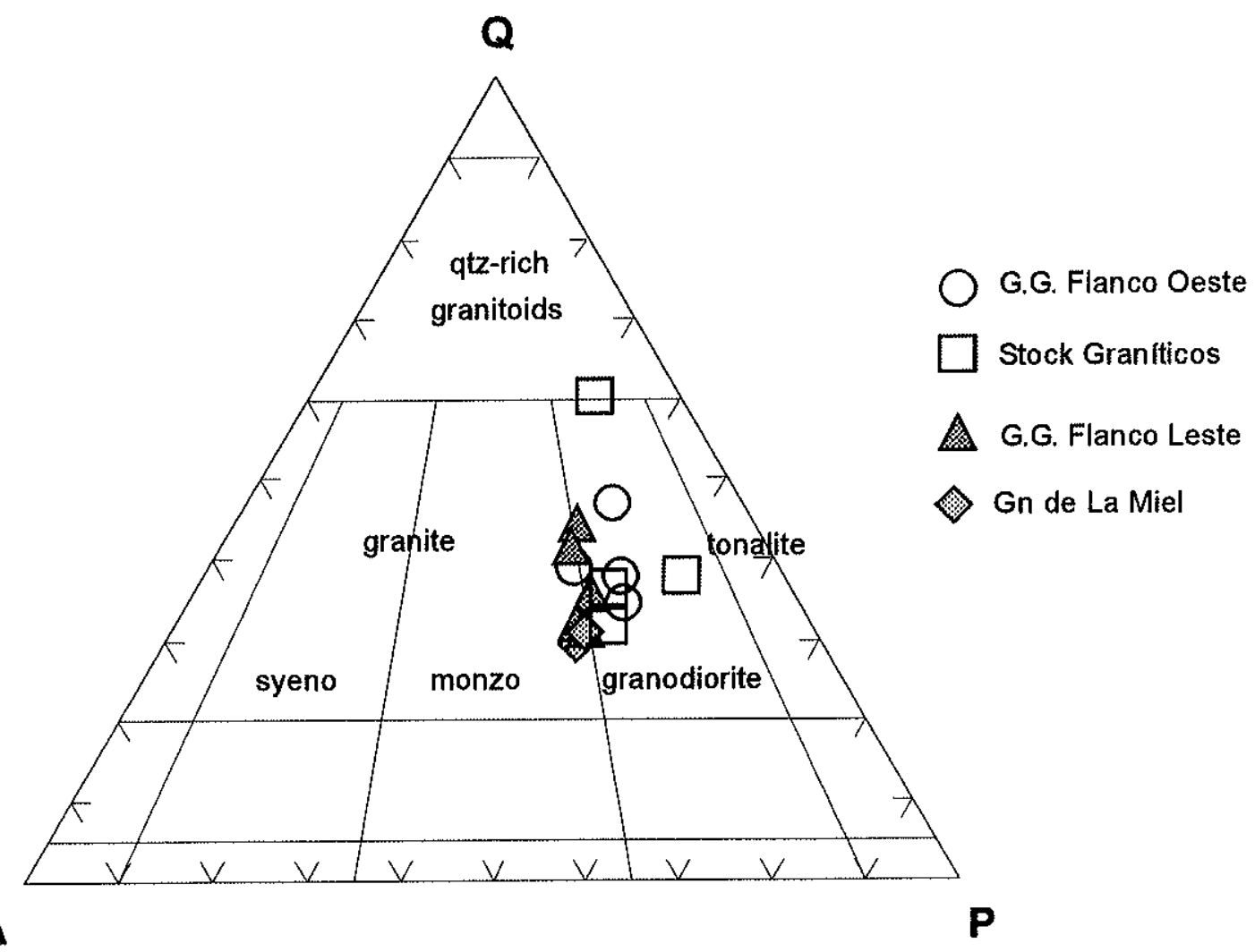

Fig. 26 QAP para os granitos gnáissicos e stocks graníticos da Cordilheira Central da Colómbia. 
Os stocks graníticos de Amagá e la Honda localizam-se no campo dos granodioritos.

A análise dos elementos maiores mostra que existe uma consistência geral na composição das rochas em estudo e não é observada uma notável diferença entre os granitos gnáissicos dos dois lados da cordilheira, formando trends composicionais evidenciados nos diagramas de Harker (Fig. 27). A notável exceção corresponde ao gnaisse de La Miel, que aparece com comportamento diferente. O stock granítico de Amagá parece se ajustar bem dentro dos padrões regionais dos diagramas de Harker, enquanto o stock granítico de La Honda apresenta valores superiores de $\mathrm{SiO}_{2}, \mathrm{Al}_{2} \mathrm{O}_{3}, \mathrm{Na}_{2} \mathrm{O}$ mas empobrecido em outros elementos, particularmente $\mathrm{MgO}_{1} \mathrm{TiO}_{2}, \mathrm{Ni}$ e $\mathrm{Cr}$. Uma diferença importante é a baixa concentração de $\mathrm{Na}_{2} \mathrm{O}$ abaixo de $3 \%$ em peso para todos os granitos gnáissicos, comparados com os valores relativamente altos para os stocks graniticos.

O índice de saturação de alumínio (ASI) (Zen, 1986) da totalidade dos dados ultrapassa 1,1, classificando-os como "granitos fortemente peraluminosos (SPG)". A notável exceção é uma amostra do stock granitico de Amagá que apresenta características metaluminosas. De forma similar ao caso das rochas granitóides do CM de EI Oro, valores médios para ASI para as rochas estudadas são, em geral, maiores que os valores médios reportados para os granitos tipo $S$ de Lachlan fold belt na Austrália. Os valores médios de ASI são de 1,46 para os granitos gnáissicos do flanco oeste e 1,3 para os do flanco leste e finalmente de 1,34 para os stocks graniticos. Novamente, o gnaisse de La Miel situa-se por fora dos campos das outras amostras regionais, da mesma forma que as amostras do stock granítico de La Honda. Adicionalmente, as amostras situam-se no campo de granitóides tipo $S$ do diagrama Cao vs. $\mathrm{FeO}(\mathrm{T})$ e apresentam valores normativos de coríndon $>1 \%$ (Chapell e White, 2001).

No diagrama $\mathrm{K}_{2} \mathrm{O}-\mathrm{SiO}_{2}$ de Ricwood (1989), os granitos gnáissicos do flanco leste situam-se para o campo das series cálcio-alcalinas altas em $K$ enquanto os granitos gnáissicos do flanco oeste agrupam-se mais para as séries cálcioalcalinas de médio $\mathrm{K}$ mas com sobreposição considerável. Os stocks graníticos pós-tectônicos situam-se num amplo intervalo, principalmente nas series cálcio-alcalinas de médio $\mathrm{K}$, embora com altos valores de $\mathrm{SiO}_{2}$. 

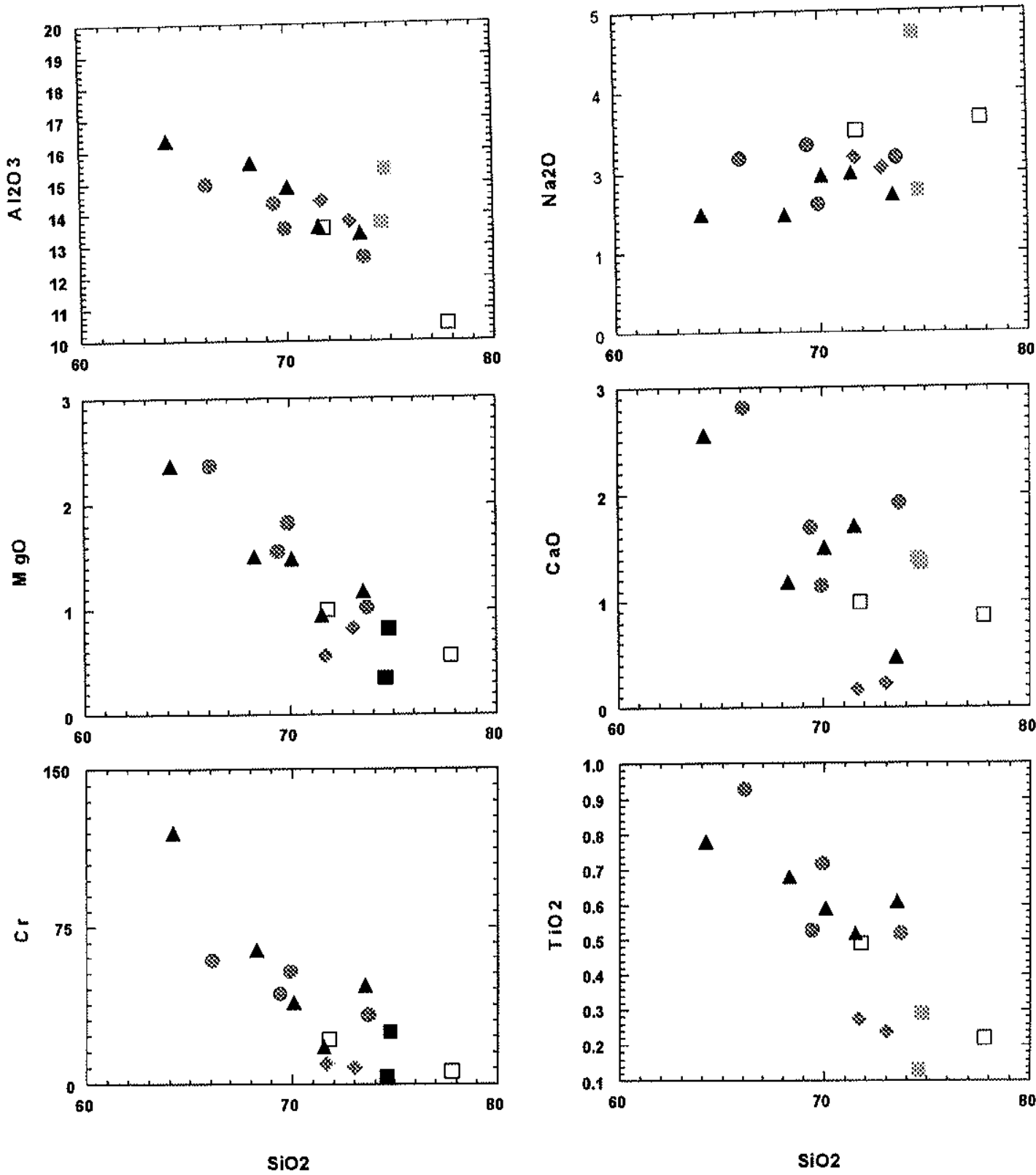

* G.G. Flanco Oeste

- Stock Graníticos

A G.G. Flanco Leste

* Gn de La Miel

Figura 27 Diagramas de Harker para os granitos gnáissicos da Cordilheira Central da Colômbia. 
Os granitóides sintectônicos estão caracterizados por altas razões $\mathrm{Rb} / \mathrm{M}$, onde $M$ pode ser um dos HREE, $\mathrm{Y}, \mathrm{Zr}$ ou $\mathrm{Hf}$ em comparação com os magmas derivados de arcos vulcânicos (Harris et al., 1986). Dados deste trabalho mostram afinidades com amostras de arcos vulcânicos, sugerindo que estas rochas poderiam ter sido formadas por fusão de rochas provenientes de um arco magmático antigo.

Os padrões dos ETR são moderadamente fracionados, observa-se uma notável consistência nos dados das rochas em estudo sem apreciável diferença entre os diferentes granitóides gnáissicos (Fig. 28a, b). 0 fracionamento observado é similar ao padrão de fracionamento apresentado pelos granitóides sin e pós-colisionais e diferente dos granitos de arcos vulcânicos (Harris, et al., 1986).

Os números de $\mathrm{Mg}$ para as amostras mostram também valores similares para os granitos gnáissicos de aproximadamente 43, enquanto o gnaisse de La Miel apresenta um valor um pouco maior de 50. O stock granítico de Amagá apresenta variabilidade no número de $\mathrm{Mg}$ com valores de até 57 , ao passo que o stock de La Honda apresenta valores de 38 (encarte 6). As amostras equatorianas apresentam valores de número de $\mathrm{Mg}$ similares às apresentadas para a Cordilheira Central da Colômbia. $O$ enriquecimento dos elementos incompativeis e os LREE, o empobrecimento dos HFSE, a anomalia negativa de $\mathrm{Nb}$ (Fig. 28c), os valores de número de $\mathrm{Mg}$ e o caráter peraluminoso sugerem uma fonte crustal para estes magmas (Inger e Harris, 1993; Harris et al., 1986).

\subsubsection{Geologia isotópica}

Composições de isótopos de $\mathrm{Nd}$ e $\mathrm{Sr}$ foram medidas para 15 amostras da parte norte da Cordilheira Central da Colômbia, principalmente para os denominados granitos gnáissicos e stocks graníticos pós-tectônicos. $O$ encarte 5 apresenta os resultados obtidos.

As razões iniciais de ${ }^{87} \mathrm{Sr}{ }^{86} \mathrm{Sr}$ para todas as amostras analisadas é alta, fornecendo uma média de 0,710 para os granitos gnáissicos (para $250 \mathrm{Ma}$ ) do flanco oeste da cordilheira; 0,7136 para os granitos gnáissicos do flanco leste $(250 \mathrm{Ma})$ e finalmente uma média de 0,7121 para os stocks graníticos $(230 \mathrm{Ma})$ no flanco oeste da cordilheira. Os valores individuais variam consideravelmente desde 0,708 até 0,714 , mostrando uma relativa heterogeneidade nos valores 

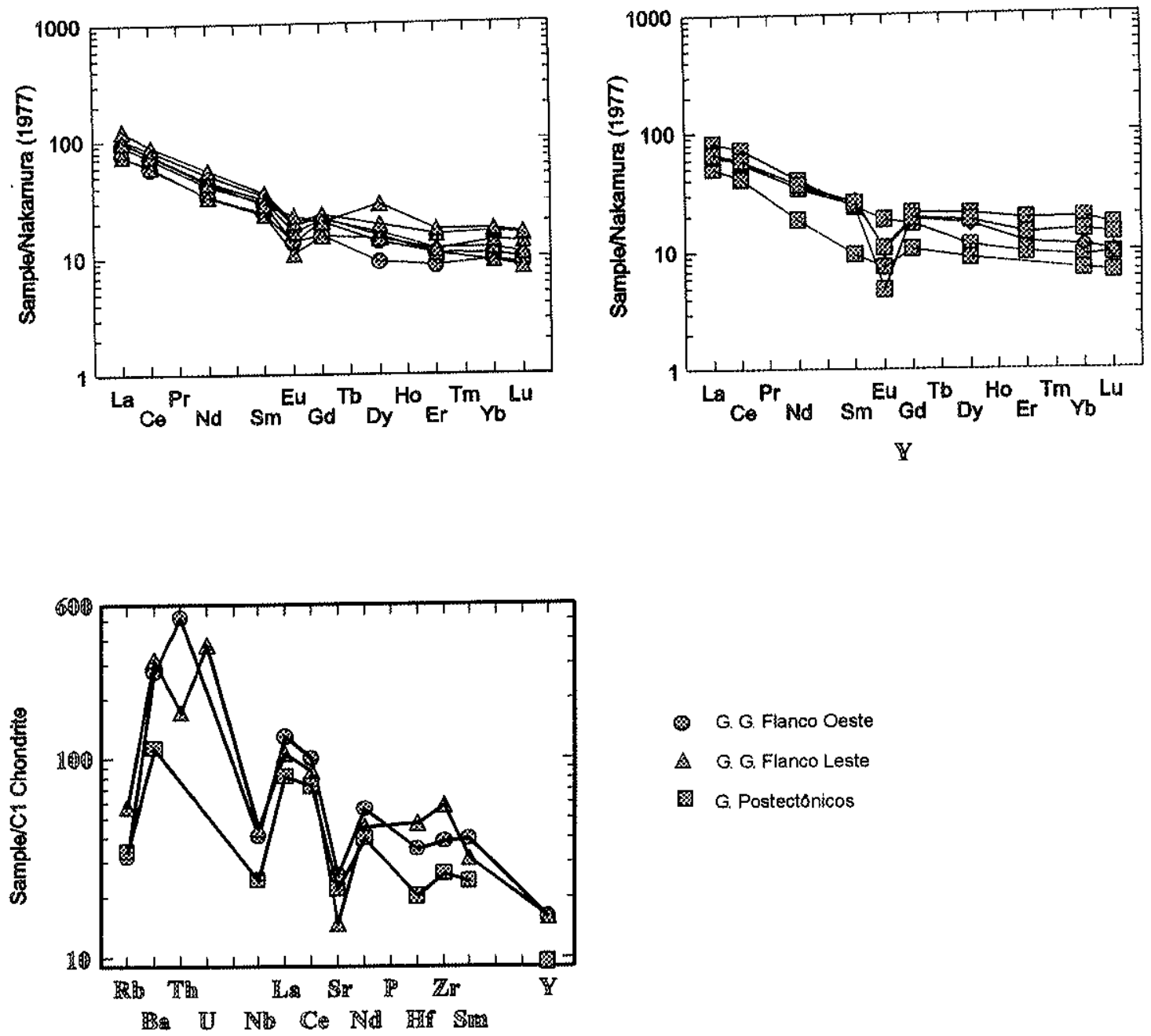
* G. G. Flanco Oeste
G. G. Flanco Leste
G. Postectónicos

Figura 28. Padrões normalizados com os condritos para os conteúdos de REE para (a) os granitos gnáisssicos da Cordilheira Central da Colômbia e para (b) os stocks graníticos pos-tectônicos. (c) Variograma com uma amostra por tipo de rochas para os mesmos grupos acima. 
iniciais da razão ${ }^{87} \mathrm{Sr}{ }^{86} \mathrm{Sr}$, o que reflete, de forma similar ao discutido para o $\mathrm{CM}$ de El Oro, uma complexa natureza dos protolitos ou ainda uma homogeneização incompleta das fontes crustais.

O valor de $\varepsilon_{\mathrm{Nd}(250)}$ para os granitos gnáissicos do flanco oeste variam entre $-4,6$ e -7; entre $-1,1$ e $-4,6$ para os stocks graníticos e entre $-3,1$ e $-8,8$ para os granitos gnáissicos do flanco leste. No diagrama de $\varepsilon_{(\mathrm{Nd})}$ vs. $\varepsilon_{(\mathrm{Sr})}$ (Fig. 29a) calculados ao presente $\left(_{0}\right.$ ), observa-se o fato das amostras se situarem no quadrante IV, de materiais provenientes principalmente de fontes crustais. As amostras pertencentes aos granitos gnáissicos agrupam-se de forma que sugerem um arranjo do tipo esperado da mistura entre um material mantélico (mantle array) com uma rocha crustal tipo Colorado front Range (DePaolo, 1981). As rochas dos granitos gnáissicos do flanco leste aparecem com uma distribuição mais espalhada, com valores extremos dos $\varepsilon_{\mathrm{Nd}}$ e $\varepsilon_{\mathrm{Sr}}$, sugerindo fontes mais diversas com aporte de materiais crustais antigos e em geral, mais evoluídos que para as rochas do flanco oeste. Caso particular é apresentado pelos stocks graníticos, os quais fogem da curva teórica de mistura. Neste caso, os valores de $\mathrm{Nd}$ permanecem num intervalo relativamente estreito enquanto $\circ \mathrm{Sr}$ apresenta valores fortemente variáveis, 0 que sugere 0 envolvimento de fluidos ricos em $\mathrm{Sr}$ possivelmente a partir das rochas encaixantes. De outro lado, os resultados graficados na figura 29a para os granitos gnáissicos do flanco oeste, incluindo dados do granito gnáissico de Puquí e o granito gnáissico de Samaná (Ordoñez, 2001) poderiam ser explicados pela mistura de material mantélico e componente crustal representado por uma rocha granulítica do grupo El Retiro, sendo o extremo crustal aquele de maior importância. Os resultados isotópicos para os granitos gnáissicos do flanco leste precisariam ser explicados pelo aporte de material mais evoluído devido ao seu maior espalhamento. Por outro lado, a tendência de fugir da linha de mistura teórica apresentada, em direção a $\varepsilon_{\mathrm{Nd}}$ menos negativo, poderia se explicar pelo aporte em pequena proporção de um terceiro componente similar isotopicamente ao metassedimento anfibólico apresentado para $0 \mathrm{CM}$ de El Oro e que na Cordilheira Central poderia estar representado por xistos cloríticos e actinolíticos paleozóicos.

As linhas de evolução de $\mathrm{Nd}$ são apresentadas na figura 19b. As idades modelo calculadas variam entre 1,4 e 1,58 Ga para os granitos gnáissicos do flanco oeste, entre 1,13 e 1,40 Ga para os stocks graníticos e entre 1,29 e 1,71 Ga para os granitos gnáissicos do flanco leste da cordilheira. As curvas envolventes correspondentes aos granitos gnáissicos do flanco leste abarcam 

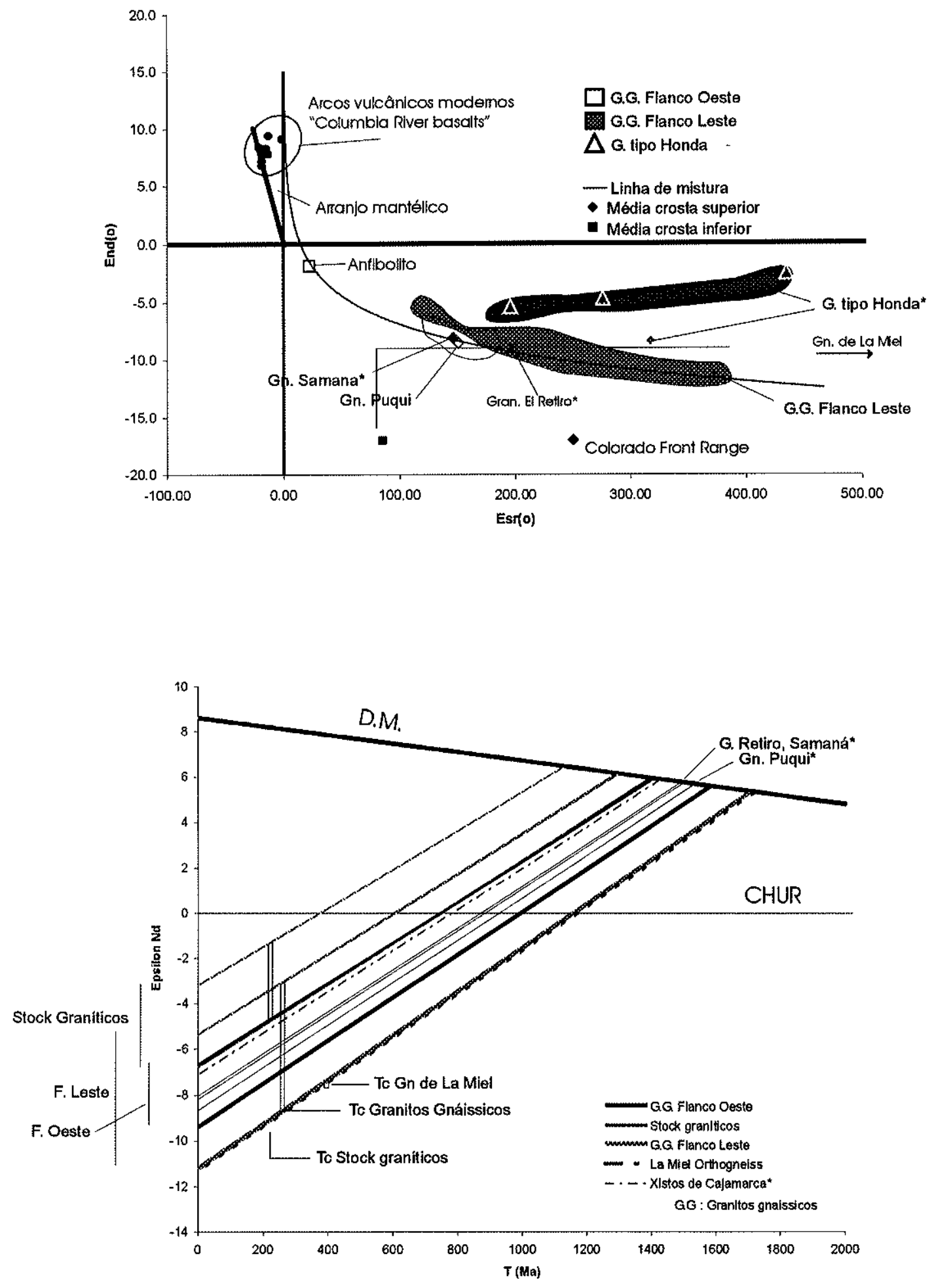

Figura 29. (a) Diagrama de correlação Epsilon Nd vs Epsilon Sr (hoje) (b) Curvas de evolução de $\mathrm{Nd}$ para as rochas da cordilheira central da colómbia. 
a quase totalidade das outras amostras, de fato cobrindo os granitos gnáissicos do flanco oeste, os metassedimentos de Cajamarca, o Granulito de El Retiro e o Gnaisse de Samaná. Os stocks graníticos aparecem num campo superior, reflexo de suas idades modelo mais jovens, o que sugere uma contribuição juvenil mais importante que para os outros corpos. Contribuição de material antigo pode se inferir para o gnaisse de La Miel, que apresenta uma curva de evolução no extremo inferior do diagrama e apresenta subseqüentemente uma idade modelo mais antiga. $O$ fato das envolventes dos granitos gnáissicos do flanco leste serem mais abrangentes, sugere o aporte de fontes mais antigas que as que geraram os granitos gnáissicos do flanco oeste, mas também sugerem o aporte de material mais juvenil, da mesma

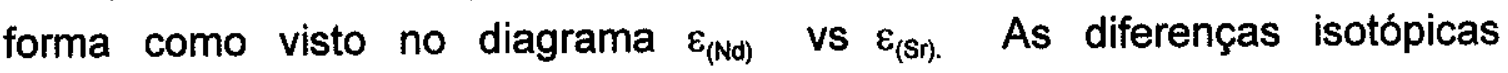
apresentadas pelos diagramas de evolução de $\mathrm{Nd}$ e o diagrama de $\varepsilon_{(\mathrm{Nd})}$ vs. $\varepsilon_{(\mathrm{Sr})}$ sugerem uma certa heterogeneidade na composição isotópica dos materiais aos dois lados da Cordilheira Central.

Da mesma forma que para os granitóides do $\mathrm{CM}$ de El Oro, o aporte de material mantélico na evolução dos granitóides da Cordilheira Central é difícil de ser avaliado, mas as amostras que apresentam os valores menos negativos de $\varepsilon_{\mathrm{Nd}}$ e subseqüentemente idades modelo mais baixas, e as razões mais baixas de $\mathrm{Sr}$ inicial são os primeiros candidatos. Pelos diagramas isotópicos estudados, os stocks graníticos pós-tectônicos tipo Amagá e La Honda, podem apresentar uma maior contribuição deste tipo na sua geração.

\subsubsection{Geocronologia}

O estudo geocronológico efetuado na presente pesquisa para as rochas da parte norte da Cordilheira Central da Colômbia compreende uma série de datações pelos métodos U-Pb SHRIMP em zircão e Ar-Ar em micas para rochas granitóides e ortognaisses. Dos cinco resultados U-Pb obtidos, duas análises contam com imagens de catodo-luminescência.

\section{Granito gnáissico de Rio Verde}

O intrusivo gnáissico de Río Verde, para leste da Cordilheira Central, apresenta zircões prismáticos curtos euédricos bipiramidais, zircões achatados facetados e zircões fragmentados. As imagens de $\mathrm{CL}$ apresentam uma variedade de estruturas internas. Aparecem núcleos luminosos sem estrutura interna e também núcleos com aparente zonação oscilatória. São comuns as 
bordas de sobrecrescimento sem estrutura interna, apenas um possivel bandeamento irregular. As seis análises foram realizadas tanto em bordas quanto nos núcleos com uma distribuição ampla de idades (Fig. 30). A idade aparente ${ }^{206} \mathrm{~Pb} /{ }^{238} \mathrm{U}$ mais antiga é registrada por um núcleo com presença de bandeamento irregular com um valor de $1171 \pm 32 \mathrm{Ma}$ (ponto 4.1). Idades um pouco mais jovens são encontradas em núcleos anédricos com valores de 831 $\pm 35 \mathrm{Ma}, 820 \pm 48 \mathrm{Ma}$ e $750 \pm 27 \mathrm{Ma}$ (pontos 1,$1 ; 2,1 ; 3,1$ ). As idades mais jovens são encontradas para um núcleo e uma borda, respectivamente. $O$ núcleo fornece uma idade aparente ${ }^{206} \mathrm{~Pb} /{ }^{38} \mathrm{U}$ de $290 \pm 10 \mathrm{Ma}$ e a borda sem estrutura interna uma idade de $302 \pm 4 \mathrm{Ma}$. As idades mais jovens poderiam corresponder a zircões herdados representativos do metamorfismo regional que afetou esta parte da Cordilheira Central.

Os valores de $U$ variam de 30 a $244 \mathrm{ppm}$ e de 13 a $145 \mathrm{ppm}$ para o Th. As razões Th/U variam entre 0,05 e 0,77 (encarte 9).

Análise Ar-Ar no Anfibolito de Padua, relacionado aos granitos gnáissicos do flanco leste da Cordilheira Central (Ingeominas, 1993) forneceu idades plateau em anfibólio de $246 \pm 6 \mathrm{Ma}$ e $243 \pm 4 \mathrm{Ma}$ (Fig. 31). Estas idades são as mais antigas obtidas pelo método Ar-Ar durante a presente pesquisa e embora 0 espectro apresente algumas evidências de argônio em excesso, ele confirma as idades em volta de $250 \mathrm{Ma}$ para a granitogênesis do flanco leste da Cordilheira. Estas idades são similares às obtidas para os anfibolitos do Grupo El Retiro (idades plateau de $230 \pm 1$ e $231 \pm 1$ Ma e idade pseudo plateau de 232 Ma em anfibólio) no flanco oeste da cordilheira (Vinasco et al., 2001), o que parece confirmar a relação entre as rochas dos dois flancos da Cordilheira Central.

\section{Gnaisse de La Miel}

O gnaisse de La Miel, para oeste da Cordilheira Central, apresenta zircões fragmentados desde euédricos prismáticos com terminação piramidal até zircões achatados semieuédricos. As imagens de $\mathrm{CL}$ mostram um padrão complexo de estruturas. Aparecem núcleos luminosos sem estrutura interna definida com bordas de sobrecrescimento irregular (Fig. 32). As idades aparentes ${ }^{206} \mathrm{~Pb} /{ }^{38} \mathrm{U}$ mais antigas são registradas para núcleos luminosos sem

estrutura interna apreciável (pontos 4,$1 ; 3,1$ e 2,1 ) com idades Paleoproterozóicas e Neoproterozóica. As duas idades aparentes mais jovens são obtidas para um único cristal de zircão em sobrecrescimento bem definido 

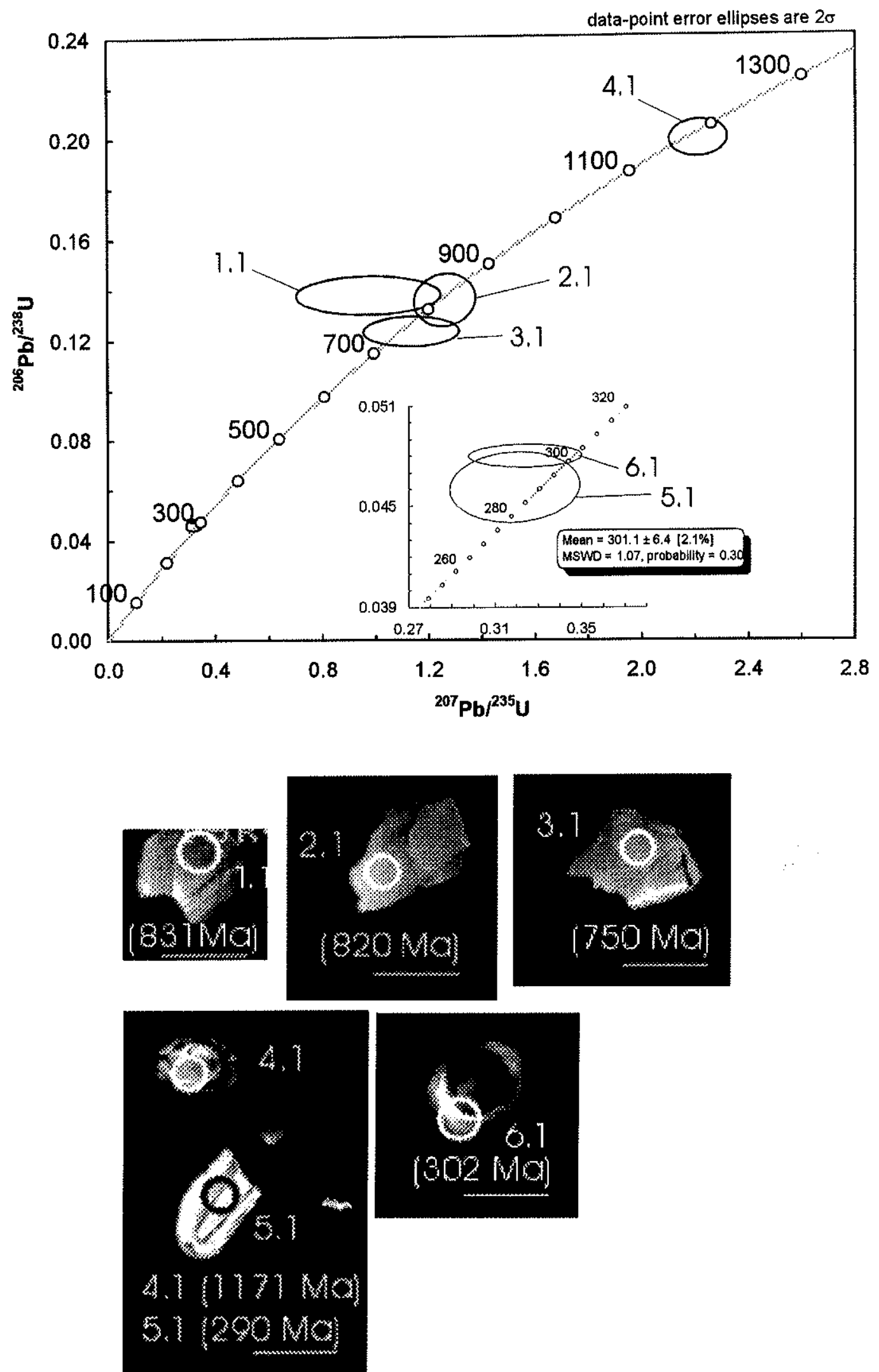

Figura 30. Granito gnáissico de Rio Verde a. Diagrama Concordia

b. Imagens de Catodo-luminescência Tamanho da barra de escala 100 micras. 
G. De La Mlel 1896 / COL-69 / Muscovite
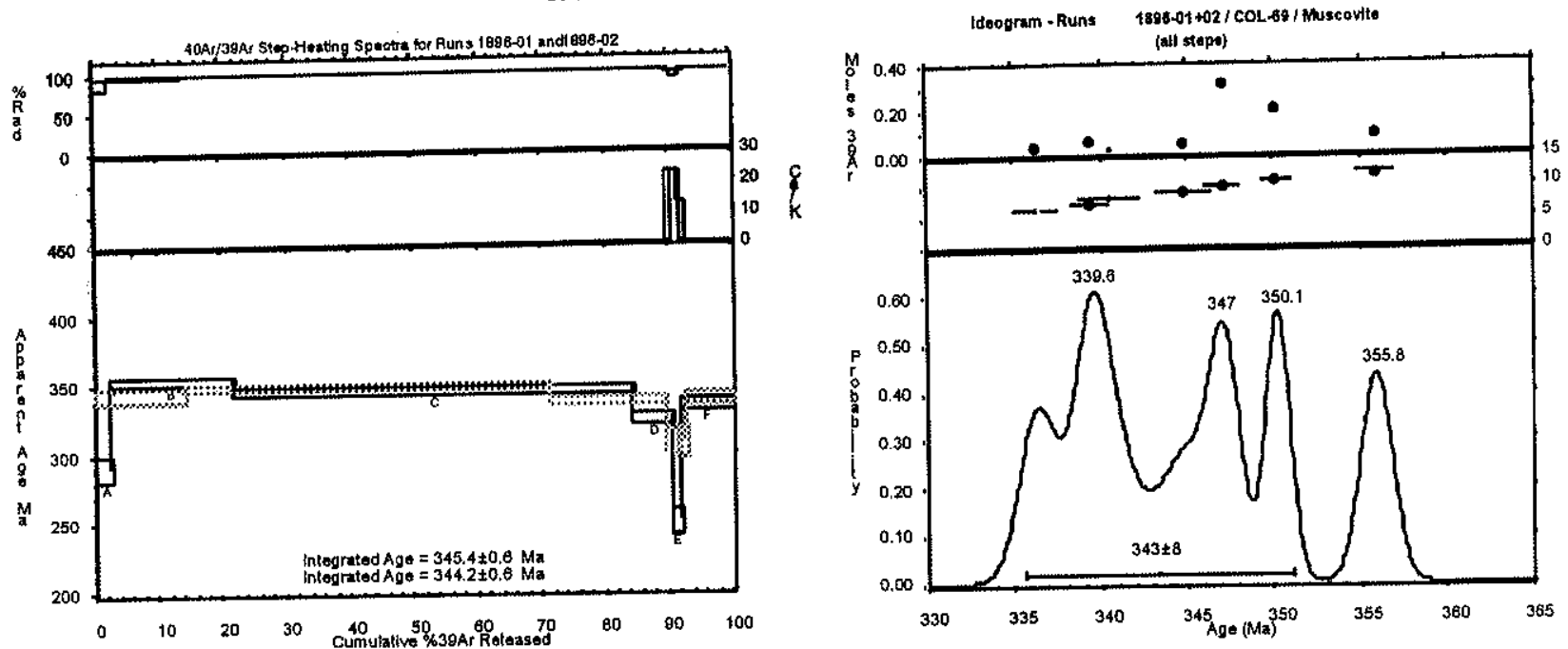

G. De Manizales $1881 / \mathrm{COL}-04$ / Muscovite

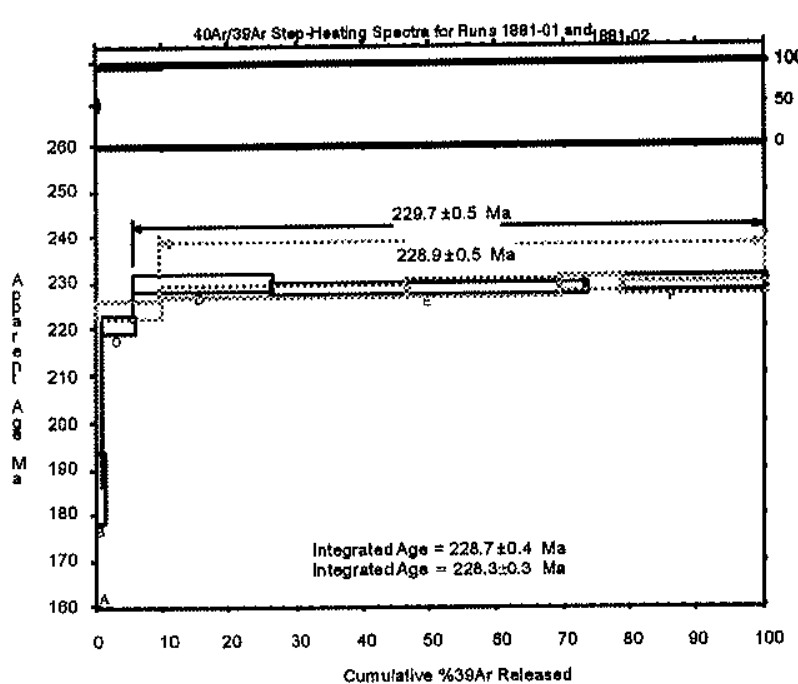

Idvogram + Runs \$881-81+02/COL-04/Muscovito

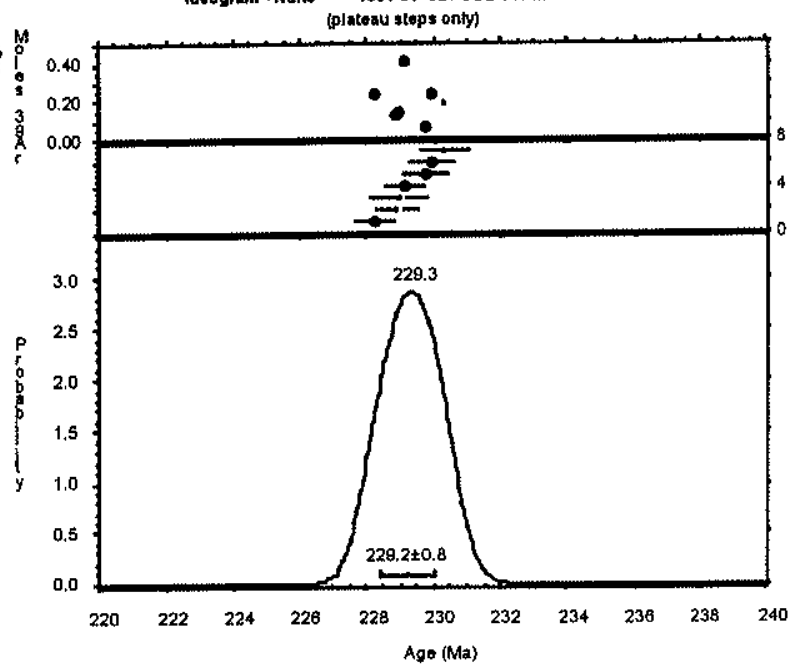

G. De Manizales 1888 / COL-04 / Blotite

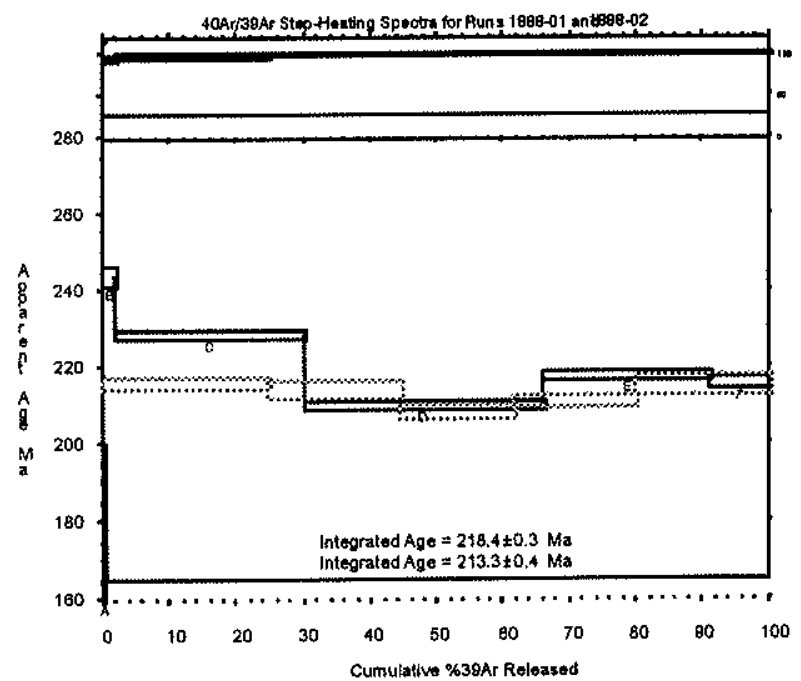

Figura 31. Espectros Ar-Ar do Gnaisse de La Miel e Granito Gnáissico de Manizales, Colômbia. 
$1890 /$ COL-08/ Amphibole
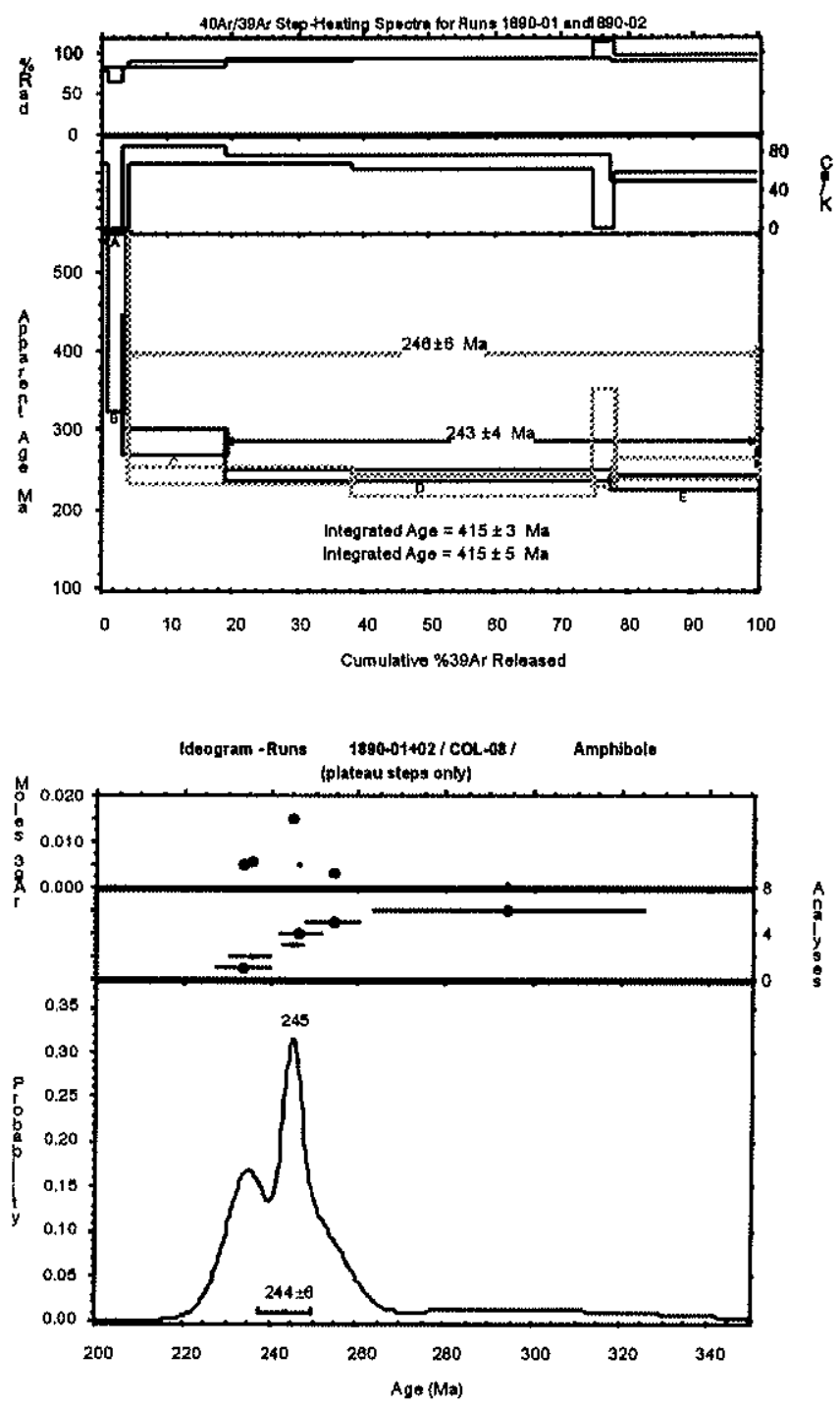

Figura 31. CONT Espectros Ar-Ar Anfibolito de Padua. 

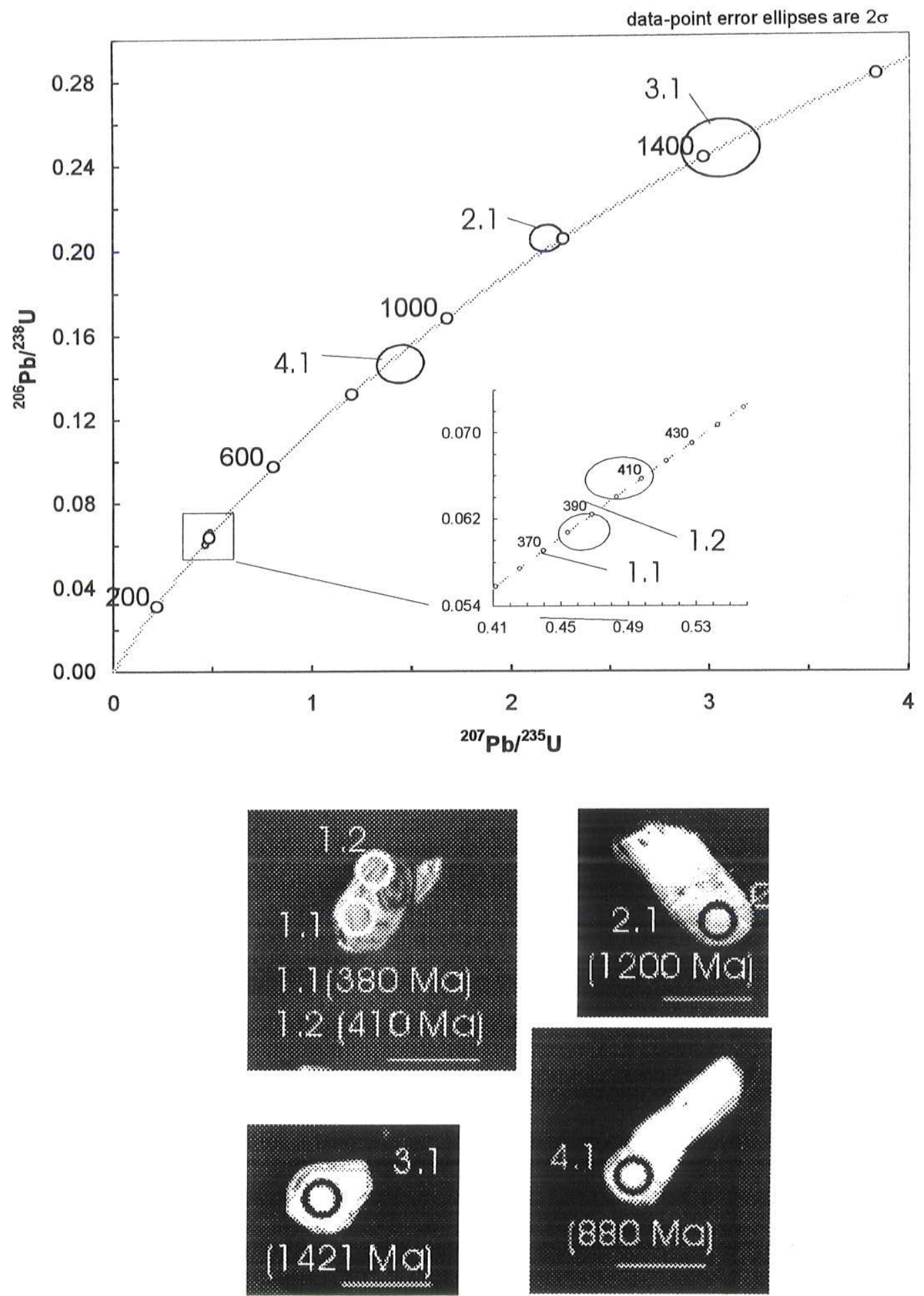

Figura 32. Gnaisse de La Miel

a. Diagrama Concordia

b. Imagens de Catodo-luminiscência

Tamanho da barra de escala 100 micras. 
com zonação oscilatória não muito fina (pontos 1,2 e 1,1). Uma idade aparente de $410 \pm 10 \mathrm{Ma}$ na parte interna do sobrecrescimento é uma idade aparente de $380 \pm 8 \mathrm{Ma}$ na parte externa de um sobrecrescimento num crescimento contínuo, são interpretadas como as idades de cristalização magmática do corpo.

Resultados Ar-Ar obtidos em muscovita apresentam espectros relativamente de boa qualidade, porém sem formaçăo de idades plateau. As idades integradas obtidas são de $345,4 \pm 0,6 \mathrm{Ma}$ e $344,2 \pm 0,6 \mathrm{Ma}$ e os picos de distribuição de idades ideograma vão desde 340 até $356 \mathrm{Ma}$ aproximadamente (Fig. 31). As idades obtidas confirmam sua idade Paleozóica, mais antiga que - restante dos gnaisses graníticos e granitóides permianos do restante da parte norte da Cordilheira Central. As idades Ar-Ar reportadas poderiam sugerir um rejuvenescimento isotópico para este corpo, mas seu significado geológico permanece obscuro.

\section{Granito gnáissico de Palmitas}

O intrusivo Gnáissico de Palmitas, sobre o flanco oeste da Cordilheira Central da Colômbia, apresenta um intervalo amplo de idades aparentes ${ }^{206} \mathrm{~Pb} /{ }^{238} \mathrm{U}$ (Fig. 33). As idades mais antigas apresentam-se levemente discordantes, sugerindo processo de perda de $\mathrm{Pb}$ de materiais proterozóicos. Outras idades mais jovens, no final do Proterozóico e Paleozóico inferior, aparecem de forma concordante. A idade de $377 \pm 1 \mathrm{Ma}$ é similar às idades de cristalização encontradas para o gnaisse de La Miel. Pela falta de imagens de catodoluminescência, é difícil estabelecer com maior confiança o tipo de fenômeno geológico e sua interpretação mais precisa, embora as idades mais jovens obtidas numa média de idade ponderada de $242,5 \pm 3,4$ Ma para dois pontos (MSWD 1,10, probabilidade de ajuste de 0,29 ) poderiam corresponder à idade de cristalização do corpo. Idades um pouco mais antigas, de $250 \pm 1 \mathrm{Ma}$ e 260 $\pm 2 \mathrm{Ma}$ são difíceis de serem explicadas e eventualmente correspondem ao mesmo evento geológico com início precoce de magmatismo.

Os valores de $U$ variam entre 54 e $965 \mathrm{ppm}$ e o Th varia amplamente entre 42 e $555 \mathrm{ppm}$ e razões Th/U varia de 0,81 até 0,09 nos zircões mais jovens (encarte 9). 


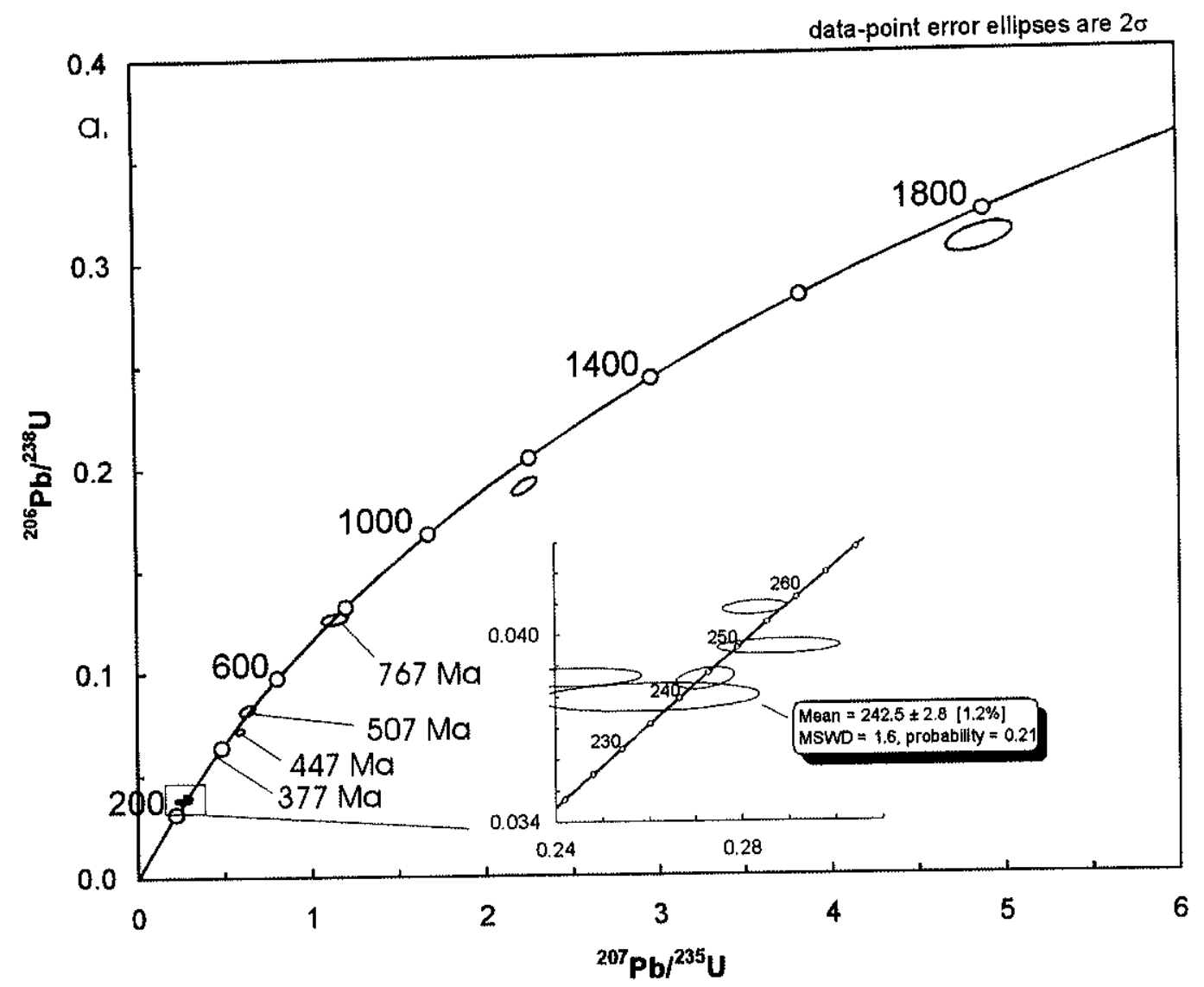

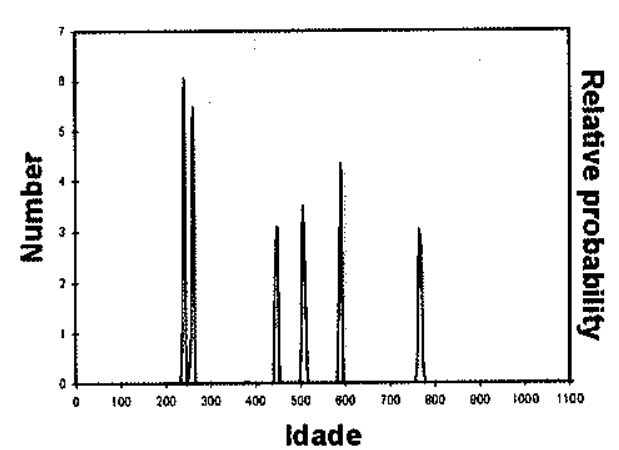

b.

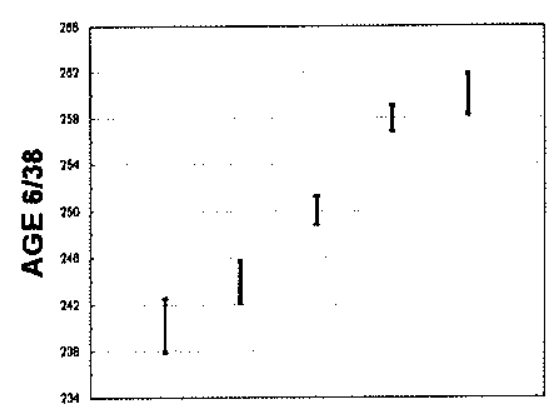

C.

Figura 33 Granito gnáissico de Palmitas

a. Diagrama Concordia

b. Plot de densidade de probabilidade de idade,

c. Média de idades ponderadas. 


\section{Gnaisse de Abejorral}

O gnaisse de Abejorral, também sobre o flanco ocidental da Cordilheira Central, apresenta um intervalo amplo de idades aparentes ${ }^{208} \mathrm{~Pb} /{ }^{238} \mathrm{U}$ (Fig. 34). As idades encontradas aparecem concordantes, sugerindo a presença de eventos com significado geológico. As idades aparentes mais antigas, estão entre $1094 \mathrm{Ma}$ e $920 \mathrm{Ma}$. No final do Neoproterozóico aparecem dois dados com valores de 692 e $500 \mathrm{Ma}$. As idades mais jovens se agrupam relativamente bem no Permiano. Um grupo de quatro pontos fornece uma idade média ponderada de $274 \pm 9,6 \mathrm{Ma}$ (MSWD 1,4, probabilidade de ajuste de 0,23 ), que pode indicar a idade do metamorfismo regional. As idades um pouco mais antigas, mesmo estatisticamente reconhecidas como sendo de uma população independente, podem fazer parte do metamorfismo regional. A idade de $250 \mathrm{Ma}$, também estatisticamente fora do grupo principal de idades, pode representar o magmatismo regional como interpretado para outros intrusivos gnáissicos como o granito gnáissico de Palmitas.

Os valores de $U$ variam entre 68 e $332 \mathrm{ppm}$ enquanto os valores de Th variam entre 9 e $229 \mathrm{ppm}$. As razões de Th/U variam amplamente de 0,04 a 1,02 com os valores mais jovens no Permiano registrando razões entre 0,6 e 0,9 (encarte 9).

\section{Granito gnáissico de Manizales}

O granito gnáissico de Manizales, na parte ocidental da parte norte da Cordilheira Central, porém ao sul dos outros corpos estudados (Fig. 31; encarte 3), fornece espectros de degaseificação de boa qualidade pelo método Ar-Ar para muscovita e biotita. Idades plateau em muscovita de $229,7 \pm 0,5$ e $228,9 \pm 0,5$ e idades integradas em biotita de $218,4 \pm 0,3$ Ma e $213,3 \pm 0,4 \mathrm{Ma}$ indicam claramente a continuação da granitogênesis Permo-Triássica na região. As idades mais baixas obtidas aparentemente são devidas à carência de espectros de boa qualidade e precisão na biotita, ao passo que o resultado obtido em muscovita representa adequadamente a idade de resfriamento do corpo.

\section{Stock granítico de Amagá}

O granitóide de Amagá, sobre o flanco oeste da Cordilheira Central, apresenta um intervalo amplo de idades aparentes ${ }^{206} \mathrm{~Pb} /{ }^{238} \mathrm{U}$ (Fig. 35). As idades 
a.
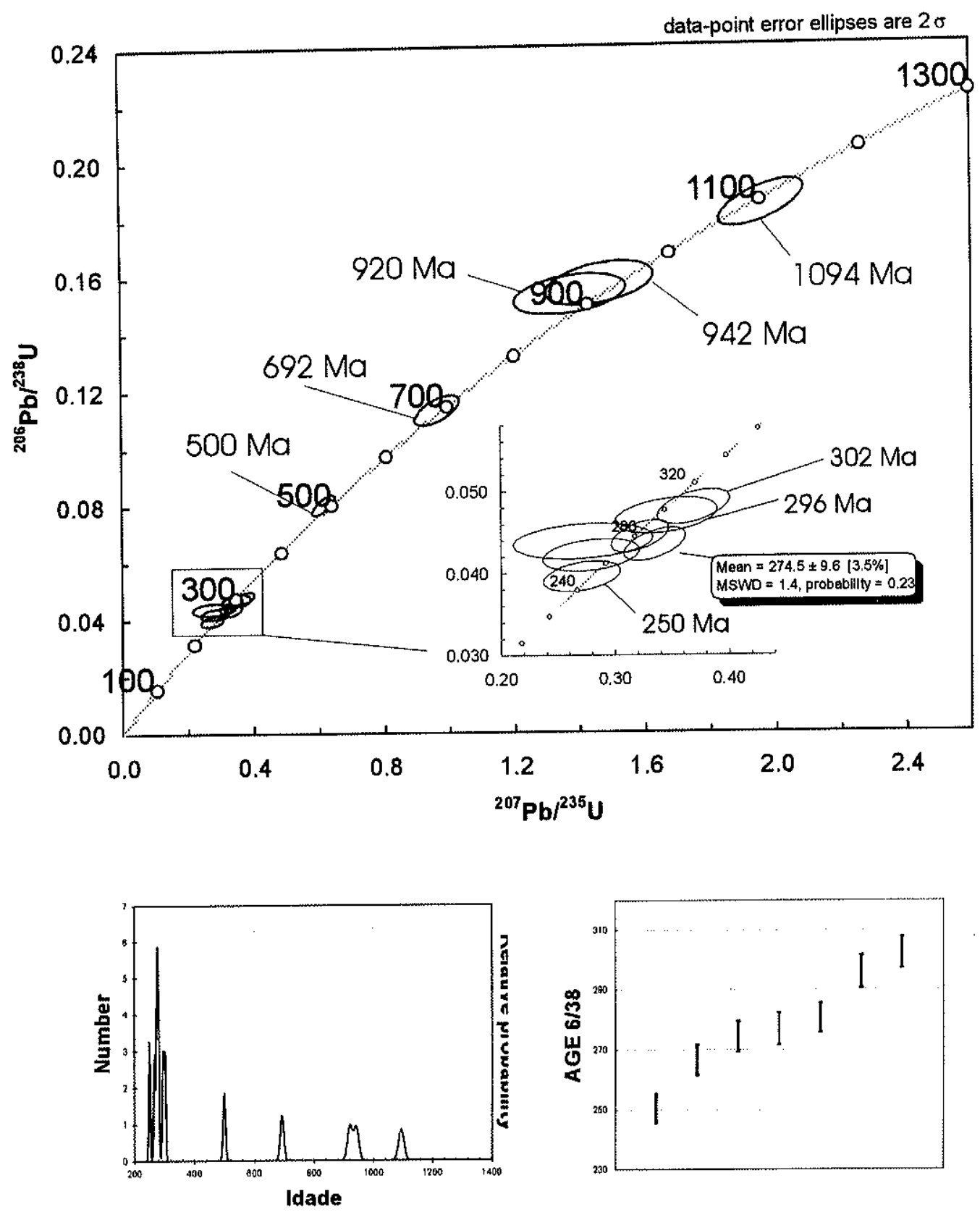

b.

c.

Figura 34. Gnaisse de Abejorral

a. Diagrama Concordia

b. Plot de densidade de probabilidade de idade,

c. Média de idades ponderadas. 
a.
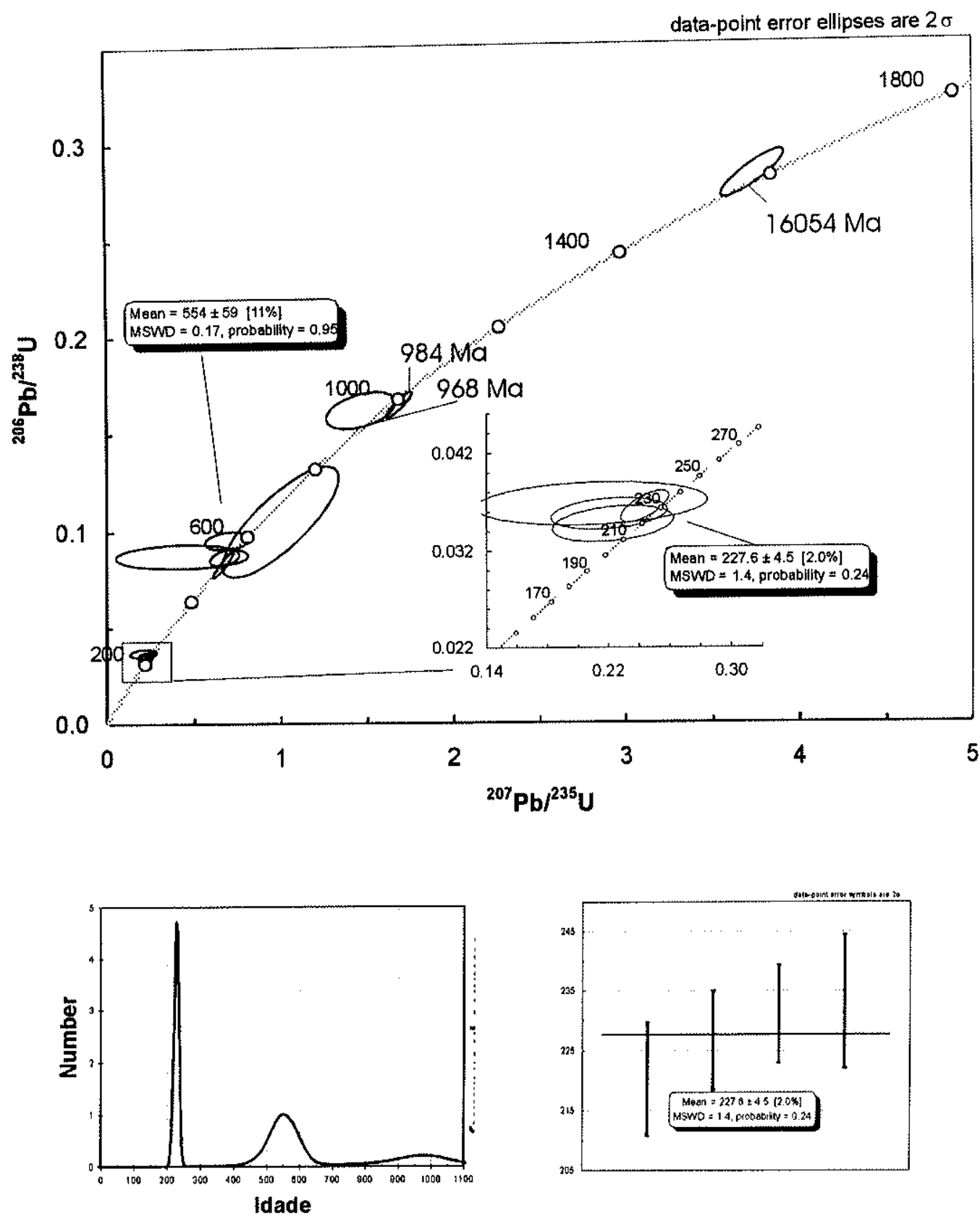

b.

c.

Figura 35. Stock de Amagá

a. Diagrama Concordia

b. Plot de densidade de probabilidade de idade,

c. Média de idades ponderadas. 
encontradas são concordantes, e da mesma forma que as anteriores sugerem a presença de eventos formadores de rochas. A idade aparente mais antiga é de $1605 \mathrm{Ma}$ e outras idades a 968 e $984 \mathrm{Ma}$ também aparecem. Um agrupamento importante de idades com idade média ponderada para 5 pontos de $554 \pm 59 \mathrm{Ma}$ (MSWD 0,17, probabilidade de ajuste 0,95) representa um importante evento geológico de possíveis implicações regionais. As idades mais jovens formam um grupo aparentemente coerente de idades com uma média de idade ponderada de 227,6 \pm 4,5 Ma para 4 pontos (MSWD 1,4, probabilidade de ajuste de 0,24 ). Esta idade é considerada como a idade de cristalização do corpo.

Os valores de $U$ variam amplamente entre 28 e $660 \mathrm{ppm}$ e os de Th entre $16 \mathrm{e}$ 191. As razões Th/U variam amplamente entre 0,03 e 1,44.

\subsubsection{Comentários sobre a evolução}

Os indicadores geoquímicos e isotópicos indicam igualmente para as rochas do CM de El Oro e os granitóides da Cordilheira Real, uma derivação por retrabalhamento crustal para os ortognaisses permianos e stocks graníticos triássicos fortemente peraluminosos da parte norte da Cordilheira Central de Colômbia com uma contribuição variável de material mantélico. Os padrões obtidos para a maior parte dos diagramas de Harker sugerem que estas rochas poderiam fazer parte de uma única suite granítica (sensu White et al., 2001). A amostra do gnaisse de La Miel é a única exceção, situa-se em geral fora do campo dos gnaisses graníticos e tem idade mais antiga. Estas rochas estão intimamente associadas ao metamorfismo regional, paragnaisses migmatíticos e metassedimentos, eles provavelmente se formaram durante o metamorfismo regional por processos anatécticos, ao passo que os stocks graníticos póstectônicos, com uma maior proporção de material mantélico, teriam sido mobilizados $e$ intrudidos em niveis superiores da crosta num ambiente predominantemente distensivo.

Os granitos gnáissicos colombianos parecem relativamente similares aos granitóides tipo $S$ de Chapell e White (2001), pela presença de muscovita ou cordierita, mais do que $1 \%$ de coríndon normativo, intervalo estreito e valores altos de $\mathrm{SiO}_{2}$, caráter peraluminoso e altas razões de ${ }^{87} \mathrm{Sr}-{ }^{86} \mathrm{Sr}$ iniciais. Os dados dos granitóides colombianos situam-se dentro do campo dos granitóides peraluminosos tipo S (PSGS) de Patiño-Douce (1999), não formados exclusivamente como magmas puramente crustais ou magmas ricos em 
restitos, mas pela interação de magmas basálticos com rochas metassedimentares ricas em Al a niveis crustais relativamente rasos (15$20 \mathrm{Km}$ ) (Patiño-Douce, 1999). Adicionalmente, os granitos gnáissicos colombianos tendem a apresentar baixas razões $\mathrm{Al}_{2} \mathrm{O}_{3} / \mathrm{TiO}_{2}$ no diagrama $\mathrm{CaO} / \mathrm{Na}_{2} \mathrm{O}$ vs. $\mathrm{Al}_{2} \mathrm{O}_{3} / \mathrm{TiO}_{2}$ (Fig. 24b), indicativo de fusão a altas temperaturas, similares àquelas encontradas na granitogênese Herciniana e no Lachland Fold belt (Sylvester, 1988).

O aporte mantélico é sugerido pela curva de mistura teórica apresentada no diagrama $\varepsilon_{(\mathrm{Nd})}$ vs. $\varepsilon_{(\mathrm{Sr})}$, e nas curvas de evolução de Nd (Figs. 29a, b). Esta contribuição poderia se apresentar na forma de magmas ascendentes pela crosta e intrudindo o embasamento da Cordilheira Central.

Os dados dos granitóides permo-triássicos de Colômbia agrupam-se no campo de "arcos vulcânicos", ou no campo de granitóides poscolisionais no diagrama $(\mathrm{Y}+\mathrm{Nb})$ vs. $\mathrm{Rb}$ de Pearce et al. (1984). As afinidades de arco vulcânico, sugeridas também pelas baixas razões Rb/M (M pode ser HREE, $Y, Z R$ ou Hf) (Harris et al., 1986), poderiam ser explicadas como o resultado de fusão de rochas pertencentes a um antigo arco magmático, possivelmente um precursor do evento colisional permiano, visto que os diagramas de discriminação a partir de elementos traço parecem indicar as condições geodinâmicas nas quais os protolitos das rochas foram formadas (Roberts e Clemens, 1993). Por outro lado, estes resultados poderiam ser indicativos de fusão de material ígneo 0 aporte mantélico na geração dos magmas, sugerindo a posibilidade de caracterizar uma granitogênese tipo $S$ caledoniana ou mesmo tipo I caledoniana (Pitcher, 1983).

A formação dos stocks graníticos pós-tectônicos do Triássico Supérior, tipo La Honda, que incluem também o stock de El Buey e possivelmente o stock de Amagá, estaria relacionada a processos de migmatização regional na Cordilheira Central. Na área de El Retiro, a rápida descompressão sofrida pelas rochas granulíticas (Bustamante, 2003) poderia ser responsável pela fusão parcial e geração de uma importante granitogênese. Durante a descompressão adiabática e rápida denudação tectônica de uma crosta engrossada pelo processo colisional, apresenta-se formação de magmas leucograníticos peraluminosos, seja por fusão por descompressão de xistos muscovíticos, possivelmente auxiliados por aquecimento por cisalhamento, ou por fusão de xistos biotíticos com ajuda de calor mantélico na forma de intrusões basálticas ou fenômenos de delaminação (Patiño-Douce, 1999). 
Possiveis resíduos deste processo seriam as rochas de alto grau e baixa pressão reportadas na área por Correa e Martens (2000). Adicionalmente, a presença de andaluzita nos xistos de Ancón, parte do Complexo Cajamarca (Roldán, 1991; Bustamante, 2003), indica intrusão de granitóides durante a exumação, responsável por reaquecimento a condições de baixa pressão (Bustamante, 2003). As idades K-Ar, Ar-Ar e Rb-Sr no intervalo do Triássico Superior reportadas na literatura indicam provavelmente o alto fluxo termal na crosta associado a um importante período extensional relacionado ao colapso orogênico mencionado.

As idades radiométricas no intervalo permo-triássico têm sido interpretadas tradicionalmente como idades de resfriamento de metamorfismo devoniano, durante a exumação e erosão do orógeno ou como idades do metamorfismo permo-triássico (Restrepo et al., 1991). Outros autores têm atribuído este evento à geração de magmatismo a partir de cisalhamento Mesozóico, relacionado à quebra do supercontinente Pangea (Aspden et al., 1987). Neste trabalho, novos dados $\mathrm{U}-\mathrm{Pb}, \mathrm{Ar}-\mathrm{Ar}$, adicionados aos indicadores geoquímicos e isotópicos, é possivel diferenciar eventos geológicos discretos durante todo o periodo Permo-Triássico como parte de uma evolução contínua colisional. Pelo menos três picos principais são registrados nos diferentes diagramas de idade apresentados (Figs. 33, 34, 35). O primeiro pico estaria a 280-300 Ma, o segundo entre 245 e $260 \mathrm{Ma}$ e o terceiro a $230 \mathrm{Ma}$. A ampla e quase contínua distribuição de idades ao longo do Permo-Triássico é o resultado de um estado termal alto contínuo desde o metamorfismo principal no Pérmico até os regimes extensionais relacionados possivelmente com o início do rompimento do supercontinente Pangea no Triássico médio a superior.

Idades U-Pb SHRIMP obtidas em zircões herdados do gnaisse de Abejorral, junto com idades Rb-Sr e K-Ar entre 280-300 Ma, corresponderiam ao pico do metamorfismo principal, que representaria a idade do episódio colisional. Idades $\mathrm{U}-\mathrm{Pb}$ próximo de $250 \mathrm{Ma}$ corresponderiam a idades de magmatismo registradas pelos granitos gnáissicos de Palmitas e o gnaisse de Abejorral e por várias determinações $\mathrm{K}$-Ar e Rb-Sr (Restrepo et al., 1991; Ordoñez e Pimentel, 2002). Estas idades corresponderiam a um magmatismo póscolisional, responsável pela geração dos granitos gnáissicos na parte norte da Cordilheira Central. Finalmente, idades $\mathrm{U}-\mathrm{Pb}$ ao redor de $230 \mathrm{Ma}$ como definidas pelo stock granítico de Amagá, o Leucogranito de las Palmas (Ordoñez, 2001) e várias determinações $\mathrm{K}-\mathrm{Ar}, \mathrm{Rb}-\mathrm{Sr}$ e $\mathrm{Sm}-\mathrm{Nd}$, representariam 
um periodo de migmatização e intrusões relacionadas ao periodo final extensional do orógeno. 


\section{CONSIDERAÇÕES FINAIS}

Os Andes do Norte, particularmente a parte norte da Cordilheira Central da Colômbia, o CM de El Oro e o denominado terreno Loja na Cordilheira Real do Equador, apresentam características gerais de uma evolução permo-triássica de caráter colisional relacionados à aglutinação do Pangea. A parte norte da Cordilheira central da Colômbia registra o metamorfismo permiano, a granitogênese associada e a exumação do orógeno no Triássico Médio, ao passo que as rochas do $\mathrm{CM}$ de El Oro registram principalmente os episódios pós-tectônicos e de exumação do orógeno, evidenciado pelo metamorfismo regional de baixa pressão e granitogênese pós-colisional, sin a pós-tectônica, de caráter crustal dominante e com aporte de material mantélico variável.

O magmatismo pós-colisional, relacionado a fenômenos tardios dentro de um orógeno colisional, é principalmente de caráter potássico, em particular cálcio alcalino alto em K (Sylvester, 1998) o que parece ocorrer na maior parte das amostras em estudo. $O$ estágio pós-colisional define uma evolução complexa, que pode incluir episódios de extensa movimentação ao longo de sistemas de cisalhamento transcorrentes, colisão obliqua, delaminação litosférica e granitogênese fortemente peraluminosa gerada por reações de fusão por deshidratação de formações crustais (Bonin, 2004).

No caso em estudo, a geração dos magmas parece fortemente dependente do calor mantélico produzido possivelmente por delaminação e subseqüente ascensão de material quente, num modelo colisional similar aos explicados para a granitogênse Herciniana na Europa (Rottura et al., 1993) e os granitóides tipo I caledonianos na Escócia e na Irlanda (Pitcher, 1983), onde o espessamento crustal não é muito forte (Sylvester, 1998). A entrada de material mantélico, como sugerido pelos resultados isotópicos de $\mathrm{Nd} \mathrm{e} \mathrm{Sr}$ (Fig. 36) e os enclaves microgranulares máficos observados, poderia ser explicada como adição de magmas máficos na crosta representados por diques de gabro metamorfoseados tanto na Colômbia quanto no Equador, com idade similar às idades dos granitóides.

Volumes grandes de granitoides colisionais tipo $S$, magmas fortemente peraluminosos são produto de anatexia de rochas crustais, e vários modelo têm sido apresentados para explicar o processo (Patiño-Douce, 1999; Sylvester, 1988), caracterizando orogenias colisionais e processos extensionais subsequentes. Em geral, os granitóides e granitos gnáissicos 

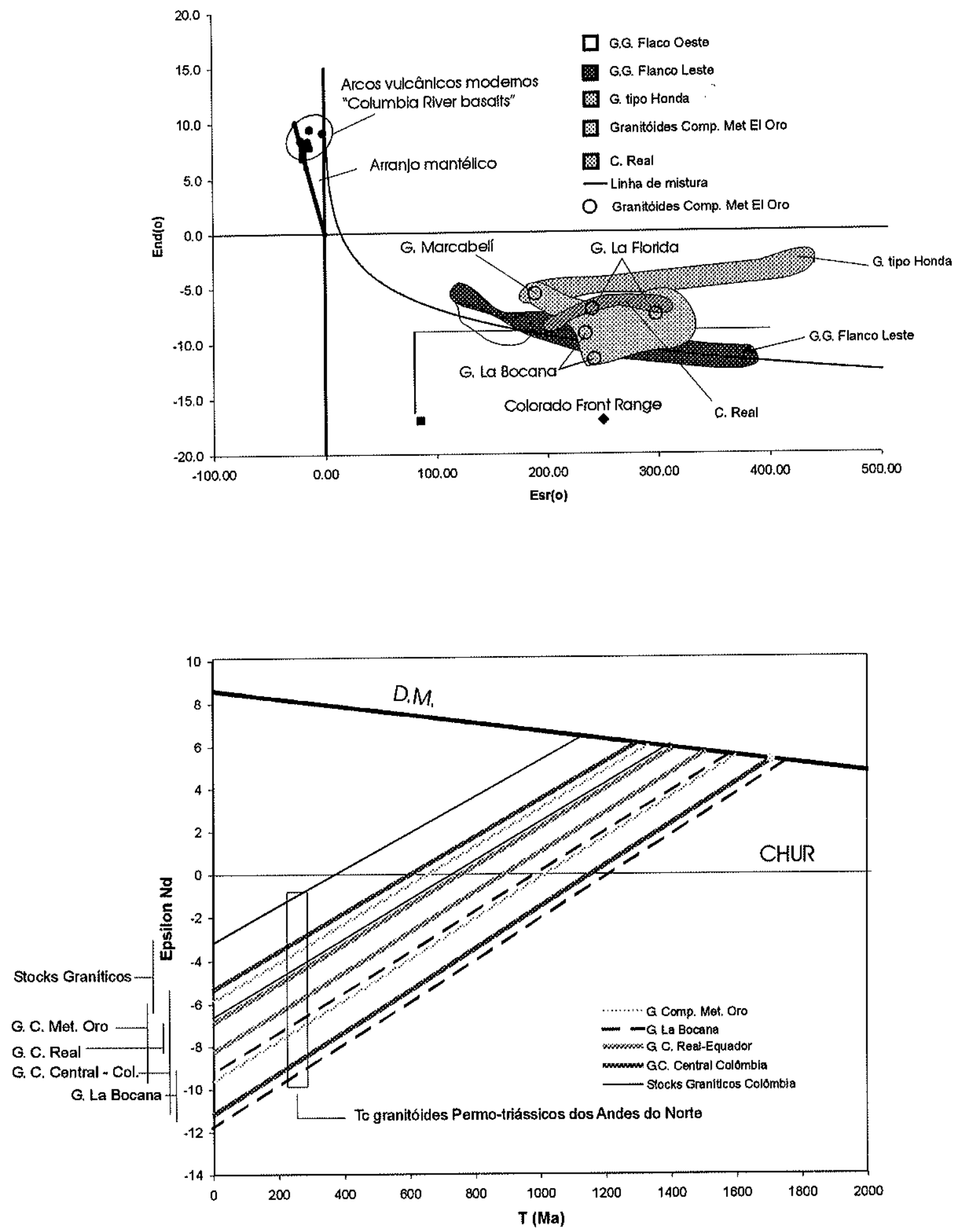

Figura 36. Diagrama de correlação Epsilon $\mathrm{Nd}$ vs Epsilon $\mathrm{Sr}$ (hoje) e Curvas de evolução de $\mathrm{Nd}$ para as rochas granitóides permo-triássicas dos Andes do Norte. 
permo-trássicos dos Andes do Norte possuem algumas características de granitóides tipo $S$ de Chapell e White (2001) e também granitóides tipo I caledonianos (Pitcher, 1983) estes últimos principalmente no CM de El Oro.

Os padrões obtidos para os ETR sugerem em geral um comportamento similar para as amostras tanto do Equador quanto para as da Cordilheira Central da Colômbia. As diferenças encontradas se apresentam principalmente nos ETR leves. $O$ grau de fracionamento é maior para os granitóides da provincia de $\mathrm{El}$ Oro, o que reflete provavelmente um grau de fusão diferente para os dois domínios, mas as fontes poderiam ser similares, como indicam os valores dos ETR pesados e a anomalia negativa de Eu. Para efeito das correlações regionais, os padrões das ETR dos granitóides do CM de El Oro se sobrepõem perfeitamente aos padrões obtidos para os granitos gnáissicos do flanco leste e oeste da Cordilheira Central de Colômbia. Os granitóides do CM de El Oro, os da Cordilheira Real, do flanco oeste e leste da Cordilheira Central da Colômbia apresentam um padrão das ETR similar ao apresentado por granitos tipo IIl ou pós-colisionais de Harris et al. (1986).

Os valores das razões iniciais de ${ }^{87} \mathrm{Sr} /{ }^{86} \mathrm{Sr}$ para todas as rochas estudadas apresentam-se elevados para a idade de $230 \mathrm{Ma}$ considerada, indicando gênese crustal com pequeno aporte mantélico. Os granitóides do CM de El Oro apresentam razőes iniciais entre 0,708 e 0,720 , ao passo que os valores encontrados para as rochas da Cordilheira Real são mais baixos, sugerindo uma importante diferença composicional. As rochas do flanco oeste da Cordilheira Central colombiana apresentam média de 0,714 , indistinguível da média das rochas da província de El Oro. Os valores de $\varepsilon_{\text {(sr) }}(t=230 \mathrm{Ma}$ ) para as rochas do $\mathrm{CM}$ de El Oro e as do flanco oeste da Cordilheira Central da Colômbia estão no intervalo +56 a +478 , com médias de +125 e +138 respectivamente. São muito próximos aos valores reportados por Harris et al. (1986) para os seus granitóides de tipo II e III ou sin-colisionais e póscolisionais respectivamente.

O estudo isotópico de $\mathrm{Sr}$ e $\mathrm{Nd}$ (Fig. 36) mostra um caráter em geral mais evoluído para os granitóides do CM de El Oro e Cordilheira Real do Equador. Os granitóides da Cordilheira Real se superpöem perfeitamente com os granitóides de La Florida e de El Prado, mas mantêm uma pequena diferença com o granitóide de Marcabelí, que parece corresponder ao corpo com o maior aporte mantélico do CM de El Oro (Fig. 36). Os granitos gnáissicos do flanco leste da Cordilheira Central da Colômbia apresentam uma maior variedade nas 
rochas fonte como sugerido pelo forte espalhamento registrado nos dados isotópicos, ao passo que os granitos gnáissicos do flanco oeste aparecem num campo mais estreito, sugerindo composições mais homogêneas nas rochas fonte. Os stocks graniticos colombianos apresentam os valores menos negativos de $\varepsilon_{\mathrm{Nd}}$ das rochas estudadas e dadas suas características intrusivas (pouca deformação, truncamento das estruturas) e geoquímicas, corresponderiam a um estágio evolutivo mais avançado na orogenia permotriássica, isto é, na direção para um magmatismo com características póstectônicas.

Os dados U-Pb SHRIMP em zircão mostram o início do magmatismo Pérmico da fase Aleganiana mais precoce na Colômbia. Idades próximas de 270 e algumas até de $300 \mathrm{Ma}$ são reportadas para granitos gnáissicos do flanco leste da Cordilheira Central, ao passo que a idade mais antiga para os granitóides do CM de El Oro é de $247 \mathrm{Ma}$ no granitóide de La Florida. Idades entre 240$250 \mathrm{Ma}$ são reportadas para granitos gnáissicos do flanco oeste da Cordilheira Central, portanto compativeis com o início de magmatismo a $240 \mathrm{Ma}$ do granitóide de La Florida. Por outro lado, o magmatismo do Triássico (230-240 Ma) apresenta uma diferença importante ao longo dos Andes do Norte, já que os granitóides do $\mathrm{CM}$ de El Oro aparecem deformados e colocados sintectonicamente em zonas de cisalhamento. A idade de resfriamento regional ao longo dos Andes do Norte, provavelmente relacionada à exumação do orógeno, está bem definida cerca de $220 \mathrm{Ma}$ tanto na Colômbia quanto no $\mathrm{CM}$ de El Oro principalmente por idades Ar-Ar.

Resumindo, os gnaisses graníticos e granitóides em estudo estão intimamente associados a metamorfismo regional, a paragnaisses migmatíticos e rochas metassedimentares. É possível que os gnaisses graníticos permianos na Colômbia (250-280 Ma) tenham sido formados durante um episódio de metamorfismo regional por processos anatécticos enquanto que, no Equador o granitóide de Marcabelí teria sido formado num processo pós-colisional, caracterizado pela colocação sintectônica ao longo de sistemas de cisalhamento por fusão eventualmente de material ígneo ou maior aporte mantélico. Os granitóides de La Bocana, La Florida e El Prado representariam estágios pós-tectônicos, porém gerados a partir de fusão de material crustal sem fusão de material ígneo subjacente. Os stocks graníticos colombianos, menos deformados, teriam sido intrudidos num ambiente distensivo com características pós-tectônicas com alguma componente mantélica. 
Uma importante diferença encontrada entre a parte norte da Cordilheira Central da Colômbia, Cordilheira Real do Equador com respeito às rochas do $\mathrm{CM}$ de El Oro, é a aparente ausência de idades de rejuvenescimento isotópico cretácicas neste último. Este fato favorece um carácter de para-autoctonia deste bloco crustal com relação ao restante dos Andes do Norte.

Finalmente, o ambiente geodinâmico durante a geração dos gnaisses graníticos na Colômbia e os granitóides triássicos no Equador está dominado pelo fechamento do proto-Atlântico entre América do Norte e América do Sul para a formação e aglutinação do Pangea (Pindell e Dewey, 1982). Uma das principais hipóteses de trabalho consiste em postular que o episódio colisional principal relacionado à Orogenia Alleganiana estaria registrado nos Andes do Norte pelos granitos gnáissicos permianos entre 250 e 300 Ma na Colômbia, e o episódio de quebramento do supercontinente registrado nos granitóides triássicos da Cordilheira Central da Colômbia e rochas do CM de El Oro, marcando o início de um periodo de rifteamento regional.

Dadas as idades U-Pb zircão entre $500-600 \mathrm{Ma}$, os blocos pré-cretácicos dos Andes do Norte teriam afinidade gondwanica. Aceitando o modelo em suas linhas gerais, bem como a possivel reconstrução geográfica dos blocos crustais de Pindell (1985), a hipótese de estudo localiza estes blocos crustais para o sul da sutura alleganiana, de forma similar aos blocos do sul da Flórida e parte do bloco Yucatán, entre a Venezuela e a costa dos Estados Unidos. Sugere-se, entretanto, que as diferenças temporais encontradas nos diferentes segmentos estudados poderiam se explicar por posições paleogeográficas particulares dentro do evento colisional. 


\section{REFERÊNCIAS}

Archanjo, C; Launeau, P. 2004. Magma flow inferred from preferred orientations of plagioclase of the Rio Ceará-Mirim dyke swarm (NE Brazil) and its AMS significance. Magnetic fabric: Methods and aplications. Geological Society, London, Special Publications, 238, 285-298. Martínez-Hernández, F., Lunenburg, C. M., Aubourg, C., Jackson, $M$. (eds).

Archanjo C., Araújo M., Launeau P. 2002. Magnetic fabric patterns of the Mesozoic Rio Ceará-Mirim Dyke swarm (Northeast Brazil) as revealed by anisotropy of magnetic susceptibility and texture analysis. Journal of Geophysical Research, No B3 V. 107: 113.

Aspden, J., Bonilla, W., Duque, P., 1995. The El Oro metamorphic Complex Ecuador: Geology and economic mineral deposits. Overseas Geology and Mineral Resources. British Geological Survey No 67, 63p.

Aspden, J., Fortey, N., Litherland, M., Viteri, F.; Harrison, S., 1992a. Regional S-type granites in the Ecuadorian Andes: possible remnants of the breakup of western Gondwana. Journal of South American Earth-Sciences, 6(3): 123-132.

Aspden, J., Harrison, S., Rundle, C., 1992b. New geochronological control for the tectono-magmatic evolution of the metamorphic basement, Cordillera Real and El Oro Province of Ecuador. Journal of South American Earth Sciences, 6(1-2): 77-96.

Aspden, J., McCourt, W., Brook, M. 1987. Geometrical control of subduction related magmatism: the Mesozoic and Cenozoic plutonic history of Western Colombia. Journal of the Geological Society, 144: 893-905.

Baldock, J.W. 1982. Geología del Ecuador. Boletín de la expplicación del mapa Geológico (1:1000 000) de la República del Ecuador. Ministerio de Recursos minerales y Energéticos, Dirección General de Geología y Minas, Quito, Ecuador. 54 p.

Barbarin, B. 1999. A review of the relationships between granitoid types, their origins and their geodynamic environments. Lithos 46: $605-626$.

Bonin, B. 1990. From orogenic to anorogenic settings: evolution of granitoid suites after a major orogenesis. Geological Journal. 25(3-4): 261-270.

Bonin, B. 2004. Do coeval mafic and felsic magmas in post-collisional and within-plate regimes necessarily imply two contrasting, mantle and crustal sources? A review. Lithos, 78. 1-24.

Borradaile, G., Henry, B. 1997. Tectonic applications of magnetic susceptibility and its anisotropy. Earth Science Reviews, 42: 49-93.

Brook, M. 1984. New radiometric age data from S.W Colombia. Ingeominas, Cali. Reporte No 10. Mision Britânica. 25 p.

Brown, M; O'Brien, P. 1997. Evolution of metamorphic belts: a changing view. Proc. $30^{\text {th }}$ Int. Geol. Cong. Vol 17, parte 11. p 217-231.

Coney, P. 1992. The Lachlan belt of eastern Australia and Circum-Pacific tectonic evolution. Tectonophysics, 21(1-4). 1-25.

Cordani, U., Cardona, A., Jimenez D., Dunyi, L., Nutman, A. (no prelo). Geochronology of Proterozoic basement inliers from the Colombian Andes: tectonic history of remmants from a fragmented Grenville belt.

Chappell, B., White, J. 1992. I and S type granites in the Lachlan fold belt. Trans. R. Soc. Edinburgh. Earth Sc. 83: 1-26. 
Chappell, B. White, J. 2001. Two constrasting granite types: 25 years later. Australian Journal of Earth Sciences, 48: 489-499.

Clarke, D., 1981. Peraluminous granites. Can. Miner., 19: 1-2.

Cobbing, J. 1996. Granites an overview. Episodes, vol 19, No 4: 103-106.

Cossio, U., Viana, R. 1986. Geología de la autopista Medellin-Bogotá entre el río Samaná Norte y Doradal. Monografia. Facultad de Minas, Universidad Nacional, Medellín.

Dalrymple, G; Lanphere, A. 1974. 40Ar/39Ar age spectra of some undisturbed terrestrial samples. In: Geoquimica and cosmochimica acta, V 38 (5): 715-738.

Dalziel, I., Dalla Salda, L., Gahagan, L. 1994. Paleozoic Laurentia-Gondwana interaction and the origin of the Appalachian-Andean mountain system. Geological Society of America Bulletin, 106: 243-252.

DePaolo, D. 1981. Nd in the Colorado Front Range and implications for crust formation and mantle evolution in the Proterozoic. Nature, 291: 193-196.

DePaolo, D. 1988. Neodymium isotope geochemistry : an introduction. Berlin; New York: Springer-Verlag. $187 \mathrm{p}$.

DePaolo, D., Linn, A., Schubert, G. 1991. The continental crustal age distribution: Methods of determining mantle separation ages from $\mathrm{Sm}-\mathrm{Nd}$ isotopic data and application to the southwestern United States. Journal of Geophysical Research, 96 (B2): 2071-2088.

D'Lemos, R., Brown M., Strachan, R. 1992. Granite magma generation, ascent and emplacement within a transpressional orogen. Journal of the Geological Society, 149: 487-490.

Dewey, J. 1984. Extensional collapse of orogens. Tectonics, v. 7: 1123-1139.

Eguez, A., Aspden, J. 1993. The Mesozoic-Cenozoic evolution of the Ecuadorian Andes. In: Andean Geodynamics, Symposium International: Oxford, United Kingdom, ORSTROM/Université d'Oxford, 215-218.

Faure, G. 1986. Principles of isotope geology. New York: Wiley. 589 p.

Feininger, T. 1978. Mapa geológico de la parte occidental de la provincia de El Oro. Escala 1/50000.

Feininger, T. 1982. The metamorphic basement of Ecuador. Geol. Soc. Am. Bull, 93: 87-92.

Feininger, T. 1987. Allochtonous terranes in the Andes of Ecuador and Northwestern Peru. Can. J. Earth Sci., 24: 266-278.

Feininger, T. Barrero, D., Castro, N. 1972. Geología de parte de los departamentos de Antioquia y Caldas (Subzona II-B). Boletín Geológico de Ingeominas, 20 (2): 1-173.

Finger, F; Roberts, M; Haunschmid, A; Schermaier, A; Steyer, H. 1997. Variscan granitoids of Central Europe: their typology, potencial sources and tectonothermal relations. Mineral and Petrology. 61. P 67-96.

Fueten, F. 1997. A computer controlled rotating polarizer stage for the petrographic microscope. Computer and Science, 23: 203-208.

Gansser, A. 1973. Facts and theories on the Andes. J. Geol. Soc. Lon., 129: 93-131. 
González, H. 1980. Geología de las Planchas 167 (Sonsón) e 187 Salamina. Boletín Geológico de Ingeominas, 23(1): 1-174.

González, H. 2000. Mapa Geológico del departamento de Antioquia. Escala 1:400.000. Memoria Explicativa. Ingeominas, Medellín. 240 p.

González, H., Nuñez, A., Paris, G. 1988. Mapa Geológico de Colombia. Memoria explicativa. Ingeominas, Colombia.

Gray, D; Foster, D; Bucher, M. 1997. Recognition and definition of orogenic events in the Lachlan Fold Belt. Australian Journal of Earth Sciences. 44. p $489-501$.

Hall, M., Calle, J. 1982. Geochronological control for the main tectono-magmatic events of Ecuador. Earth Science Reviews, 10: 215-239.

Hall, R., Alvarez, J., Rico, H. 1972. Geologia de los departamentos de Antioquia y Caldas (Subzona II-A). Bogotá, Boletín Geológico Ingeominas, 20 (1): 1-85.

Harris, N., Pearce, J., Tindle, A. 1986. Geochemical characteristics of collision zone magmatism. In: Coward, M.P., Ries, A.C., (Eds). Collision tectonics. Geol. Soc. Spec. Pub., 19: 67-81.

Hrouda, F. 1982. Magnetic anisotropy of rocks and its applications in geology and geophysics. Geol. Surv, 5: 37-82.

INGEOMINAS. 1993. Mapa geológico generalizado del departamento de Caldas. Memoria explicativa.

Irving, E. 1975. Estructural evolution of the northernmost Andes, Colombia. U. S. Geol. Surv. Prof. Pap., 846: 1-47.

Jaillard, E., Soler, P., Carlier, G., Mourier, T. 1990. Geodynamic evolution of the Northern and Central Andes during early to middle Mesozoic times: a Tethyan model. Journal of the Geological Society, 147: 1009-1022.

Jelinek, V. 1981. Characterization of the Magnetic fabrics in rocks. Tectonophysics, 79 , T63-T67. [Q95].

Kennerley, J. 1973. Geology of the Loja Province. Report of the Institute of Geological Sciences (Overseas Division), No 23.

Kennerley, J. 1980. Outline of the geology of Ecuador. Overseas Geology and Mineral resources, No 58.

Litherland, M., Aspden, J., Jemielita, R. 1994. The metamorphic belts of Ecuador. Overseas Memoir of the British Geological Survey, No 11. $147 \mathrm{p}$.

Launeau, P., Cruden, A. 1998. Magmatic fabric acquisition mechanism in a syenite: results of a combined anisotropy of magnetic susceptibility and image analysis study. Journal of Geophysical Research, 103 (B3): 5067-5089.

Launeau, P., Robin, P. (no prelo). Determination of fabric and strain ellipsoids from measured sectional ellipses - Implementation and applications. Journal of Structural Geology

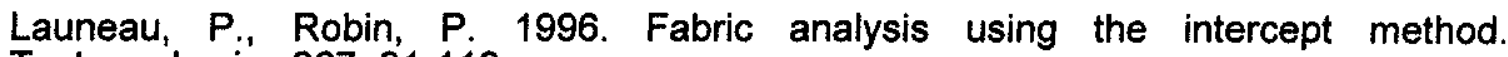
Tectonophysics 267. 91-119.

Lux, J., DeYoreo, C., Guldotti, C. Decker, E. 1986. Role of plutonism in low-pressure metamorphic belt formation. Nature 323(6091): 794-797. 
Martinez, M. 1970. Geología del basamento Paleozóico em las montañas de Amotape y posible origen del petróleo em rocas paleozóicas del noreste del Peru. Primer Congreso Latinoamericano de Geologia, V 2: 144-145.

Maya, M.; González, H. 1995. Unidades Litodémicas en la Cordillera Central de Colombia. Ingeominas (eds.). Informe Unidad Operativa Medellín, 44-57 p.

McCourt, W., Aspden, J., Brook, M. 1984. New geological and geochronological data from the Colombian Andes: continental growth by multiple accretion. Journal of the Geological Society, 141: 831-845.

McDougall, I., Harrison, T. 1999. Geochronology and Thermocronology by the ${ }^{40} \mathrm{Ar}-{ }^{39} \mathrm{Ar}$ method. Oxford University Press. New York. 269 p.

Megard, F. 1987. Cordilleran and marginal Andes; a review of Andean geology north of the Arica Elbow (18 $\mathrm{S}$ ). 1987. Geodynamics Series. 18; Pages 71-95.

Merrihue, C.; Turner, G. 1966. Potassium argon dating by activation with fast neutrons. Journal of Geophys. Res., 71: 2852-2857.

Mori, P., Reeves, S., Teixeira, C., Haukka, M. 1999. Development of a fused glass disc XRF facility and comparison with the pressed powder pellet technique at Instituto de Geociencias, São Paulo University. Revista Brasileira de Geociências, 29(3): 441-446.

Mourier, T., Laj. C., Mégard, F., Roperch, P., Mitouard, P., Farfan-Medrano, A. 1988a. An accreted continental terrane in Northwestern Peru. Earth Planetary Science Letters 88: $182-192$

Mourier, T., Mégard, F., Reyes Rivera, L., Pardo Arguedas, A. 1988b. L'evolution mésozoïque des Andes de Huancabamba (nord Pérou-sud Équateur) et l'hypothèse de l'accrétion du bloc Amotape-Tahuin. Bull. Soc. Géol. France , (8), t. IV, 1: 69-79.

Noble, S., Aspden, J., Jemielita, R. 1997. Northern Andean crustal evolution: New U$\mathrm{Pb}$ geochronological constraints from Ecuador. Geological Society of America Bulletin, 109(7): 789-798.

Ordoñez, O. 1997. O Precambriano na parte norte da Cordilheira Central dos Andes Colombianos. Brasilia. Dissertação (Mestrado) Universidade de Brasília. 99 p.

Pamic, J; Lanphere, M; Belak, Z. 1996. Hercynian I type and S type granitoids from the Slavonian mountains (southern Pannonian Basin, northern Croatia). N. Jb. Miner. Abh. 171, 2: 155-186.

Patiño-Douce, A. 1999. What do experiments tell us about the relative contributions of crust and mantle to the origin of granitic magmas?. Geological-Society-SpecialPublication. 2000; (168): 55-75.

Pindell, J., 1985. Alleghenian reconstruction and subsequent evolution of the gulf of Mexico, Bahamas, and Proto Caribbean. Tectonics, 4(1): 1-39.

Pindell, J., Dewey, J. 1982. Permo-Triassic reconstruction of Western Pangea and the evolution of the gulf of Mexico/Caribbean region. Tectonics, 1: 179-211.

Pitcher, W. 1983. Granite type and tectonic environment. In: Hsu, K., (Ed). Mountain building processes. Academic Press London, 19, cap 1-3.

Reavy, R. 1989. Structural controls on metamorphism and syntectonic magmatism; the Portuguese Hercynian collision belt. Journal of the Geological Society of London, 146(4): 649-657.

Reddy, S.; Potts, G. 1998. Constraining absolute deformation ages: the relationship between deformation mechanisms and isotope systematics. In: Journal of Structural Geology Vol 21 (8-9): 1255-1265 
Renne, P. 2000. K-Ar and 40Ar-39Ar dating. In: J.S Noller, J.M Sowers, W.M. lettis.(eds.) Quaternary Geochronology: Methods and applications. American Geophysical Union. 77-100 p.

Restrepo J., Toussaint, J. 1984. Unidades litológicas de los alrededores del Valle de Aburrá, Medellín. Sociedad Colombiana Geológica. Memoria 1: 1-26.

Restrepo, J. 1986. Metamorfismo en el sector norte de la Cordillera Central de Colombia. Inf. Univ. Nacional. Medellín. 1-27.

Restrepo, J., Toussaint, J. 1982. Metamorfismos superpuestos em la Cordillera Central de Colombia. V Cong. Latin-Amer. Geol. Argentina. 505-512 p.

Restrepo, J., Toussaint, J. 1988. Terranes and Continental accretion in the Colombian Andes. Episodes, 11 (3): 189-193.

Restrepo, J., Toussaint, J., Cordani, U., Kawashita, K., Linares, E. 1989. Geochronological review of the Northern Andes. Revista I.C.N.E. Universidad Nacional, Medellin, 2: 39-82.

Restrepo, J., Toussaint, J., González, H., Linares, E. 1978. Datación de metasedimentos del grupo Ayurá-Montebello. Publ. Esp. Geol. Universidad Nacional, Medellin, 10: 1-5.

Restrepo, J., Toussaint, J.F., González, H., Cordani, U., Kawashita, K., Linares, E., Parila, C. 1991. Precisiones geocronológicas sobre el occidente colombiano. Simposio Magmatismo Andino y su marco tectonico. Tomo I: 1-22. Manizales.

Rink, M. 1976. A computarized quantitative image analysis procedure for investigating features and na adapted image process. Journal of Microscopy, 107: 267-286.

Roberts, $M$; Clemens, J. 1993. Origin of high-potassium, calc-alkaline, I type granitoids. Geology, V.21: 825-828.

Robin, P. 2002. Determination of fabric and strain ellipsoids from measured sectional ellipses - theory. Journal of Structural geology 24: 531 - 544.

Rochette, $P$., Jackson, M., Aubourg, C. 1992. Rock magnetism and the interpretation of anisotropy of magnetic susceptibility. Reviews of Geophysics, 30 (3): 209-226.

Rollinson, H. 1993. Using geochemical data: evaluation, presentation, interpretation. Longman Scientific and Technical; UK. (August 1993). 352 p.

Sato, K., Tassinari, C.C.G., Kawashita, K. and Petronilho, L. 1995. O Método Geocronológico Sm-Nd no IG/USP e suas Aplicações. An. Acad. Bras. Ci., Vol. 67: 313-336

Rottura, A; Caggianelli, A; Campana, R; Del Moro, A. 1993. Petrogenesis of Hercynian peraluminous granites from the Calabrian Arc, Italy. Eur. J. Mineral. 5: 737 - 754.

Sepúlveda, R., Saldarriaga, S. 1980. Metamorfismo de las rocas del oriente del municipio de Caldas (Antioquia). Trabajo de grado. Universidad Nacional, Medellín.

Shimamoto, T., Ikeda, Y. 1976. A simple algebraic method for strain estimation from deformed ellipsoidal objects. 1. Basic theory. Tectonophysics, 36: 315-337.

Stern, R.A. 1997. The GSC Sensitive High Resolution Ion Microprobe (SHRIMP): analytical techniques of zircon $\mathrm{U}-\mathrm{Th}-\mathrm{Pb}$ age determinations and performance evaluation. In: Radiogenic Age and Isotopic Studies: report 10. Geol. Surv. Can., Current Research 1997-F: 1-31.

Sylvester, P. 1998. Post-collisional strongly peraluminous granites. Lithos 45: 29-44. 
Tarling, D.H., Hrouda, F. 1993. The magnetic anisotropy of rocks. Chapman \& Hall, London. $232 \mathrm{p}$.

Tassinari, C., Cordani, U., Nutman, A., Van-Schmus, W., Bettencourt, J., Taylor, P. 1996. Geochronological systematics on basement rocks from the Rio Negro- Juruena Province (Amazonian Craton) and tectonic implications. International-Geology-Review. 1996. 38/2, 161-175.

Toussaint, J., González, H., Linares, E. 1978. Edad K-Ar de tres rocas metamórficas del flanco noroccidental de la Cordillera Central. Publicación Especial Geológica. Medellin, Facultad de Ciencias, No 14.

Toussaint, J.F. 1993. Evolución geológica de Colombia. Precámbrico-Paleozóico. Univ. Nac. De Colombia, 129 p. Medellín.

Vesga, C., Barrero, D. 1978. Edades $\mathrm{K} / \mathrm{Ar}$ en rocas ígneas y metamórficas de la Cordillera Central de Colombia y su implicación geológica. II Congreso Colombiano de Geología, Bogotá. Abstract, 21-31 p.

Vinasco, C., Cordani, U., Vasconcelos, P. 2001. 40Ar/39Ar dates in the central cordillera of Colombia: Evidence for an upper triassic regional tectonomagmatic event. Ext. Abstracts. III SSAGI. Pucón, Chile. 638-641 p.

Wickham, S., Oxburgh, R. 1985. Continental rifts as a setting for regional metamorphism. Nature (London). 318; 6044: 330-333.

Williams, I. 1998. Society of Economic Geologist short course: Applications of microanalytical techniques to understanding mineralizing processes, Reviews in Economic Geology, 7. U-Th-Pb geochronology by ion microprobe. McKibben, M., Shanks III, W., Ridley, W Ed. 1-35 p.

Zen, E. 1986. Aluminum enrichment in silicate melts by fractional crystalization: some mineralogic and petrographic constraints. J. Petrol, 27: 1905-1117. 
6. ANEXOS 
ASM DO PLUTÃO DE MARCABELI, COMPLEXO

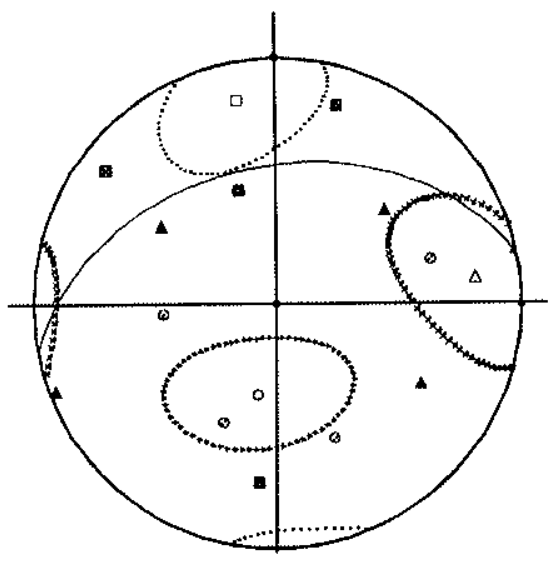

- $\mathrm{K} 1$

- $\mathrm{K} 2$

- K3
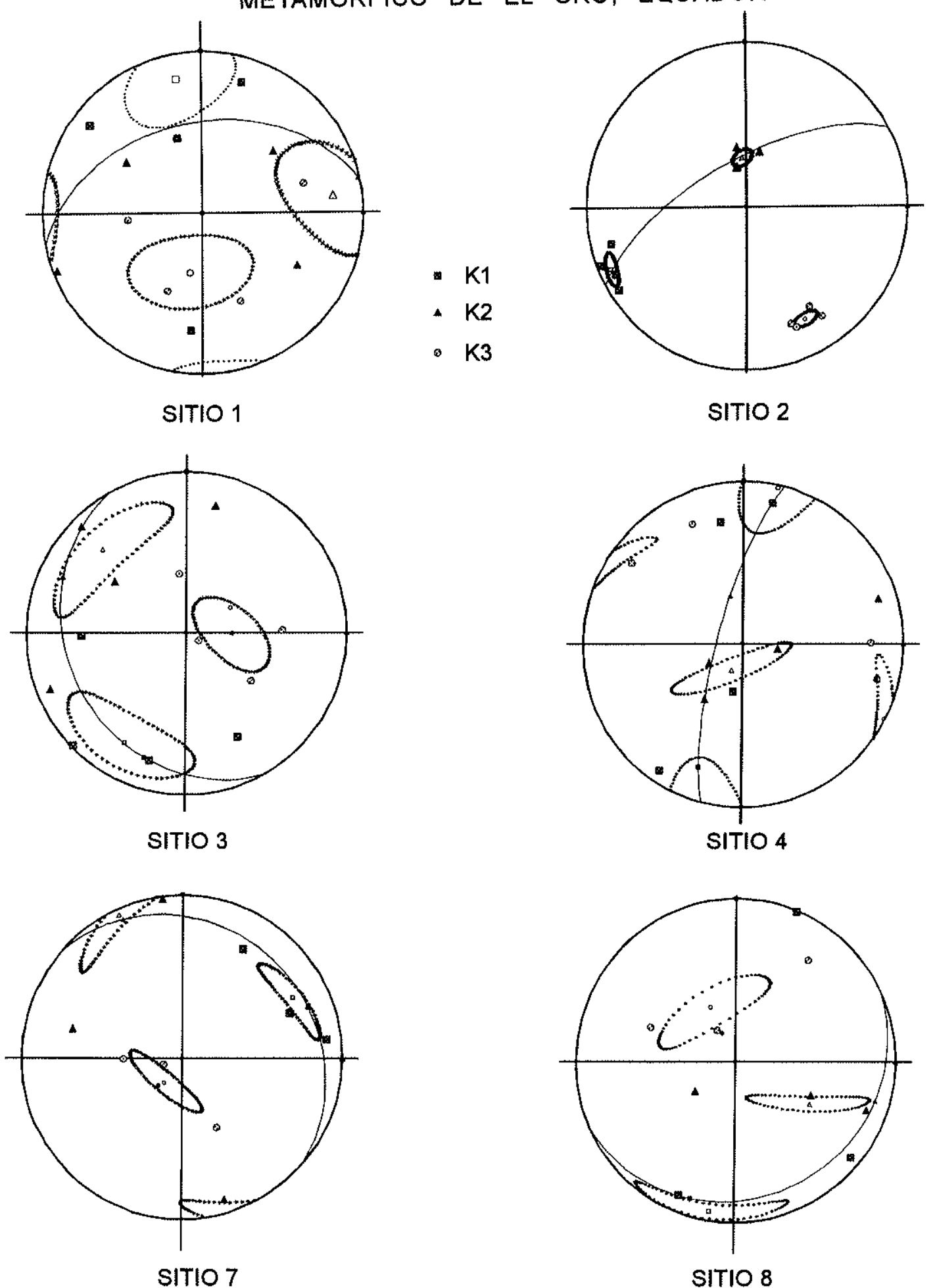
ASM DO PLUTÃO DE MARCABELI, COMPLEXO METAMÓRFICO DE EL ORO, EQUADOR

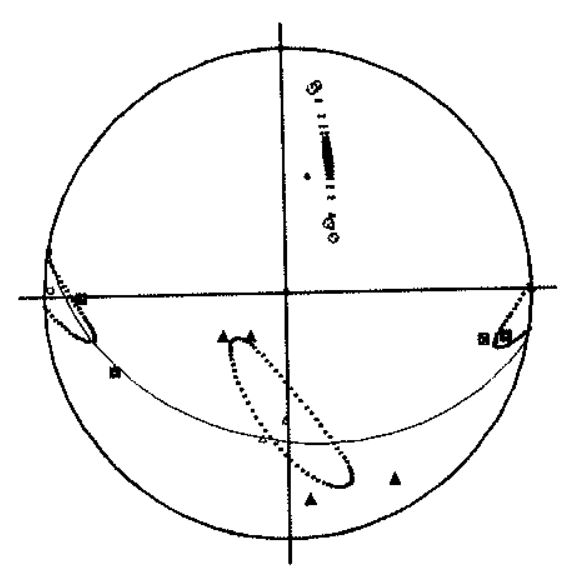

- $\mathrm{K} 1$

A $\mathrm{K} 2$

- K3

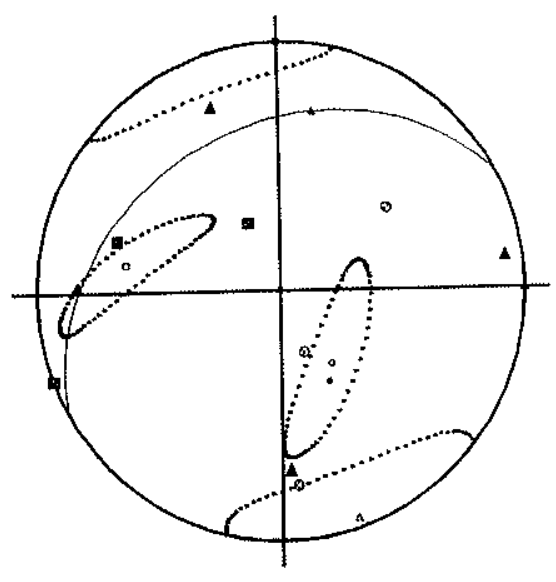

SITIO 12
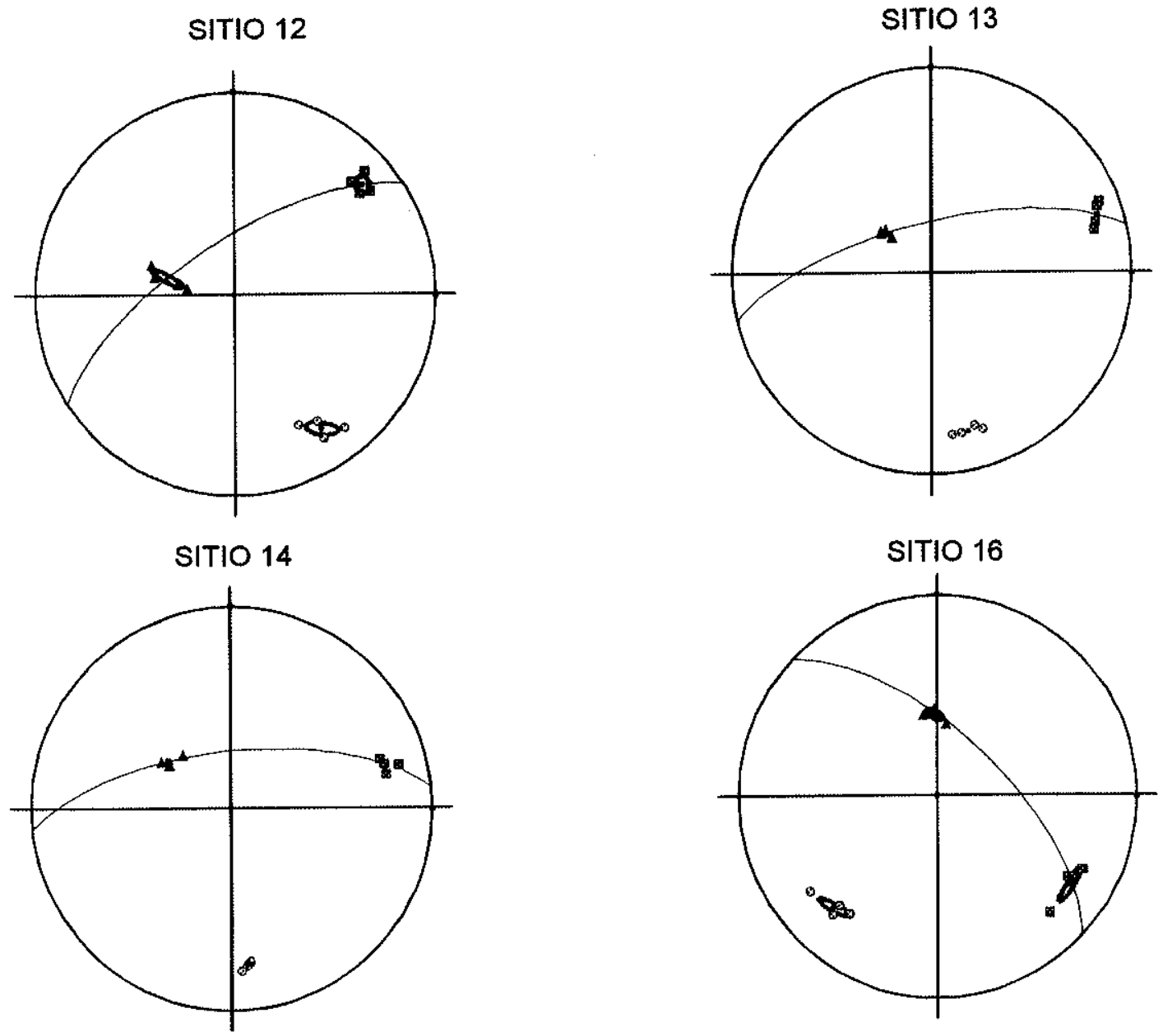

SITIO 17

SITIO 18 
ASM DO PLUTÃO DE MARCABELI, COMPLEXO METAMÓRFICO DE EL ORO, EQUADOR

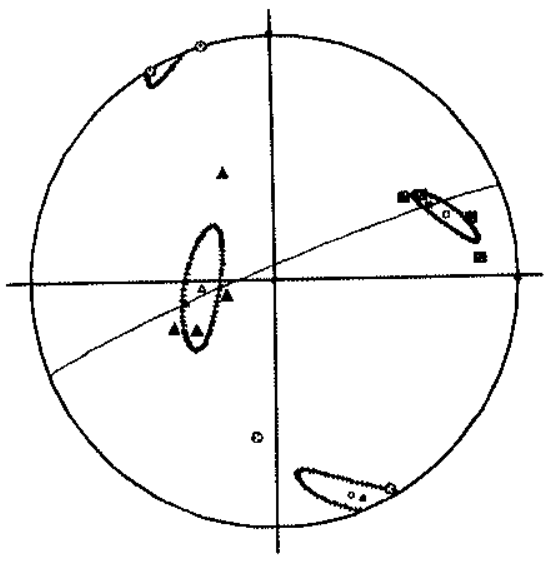

SITIO 19

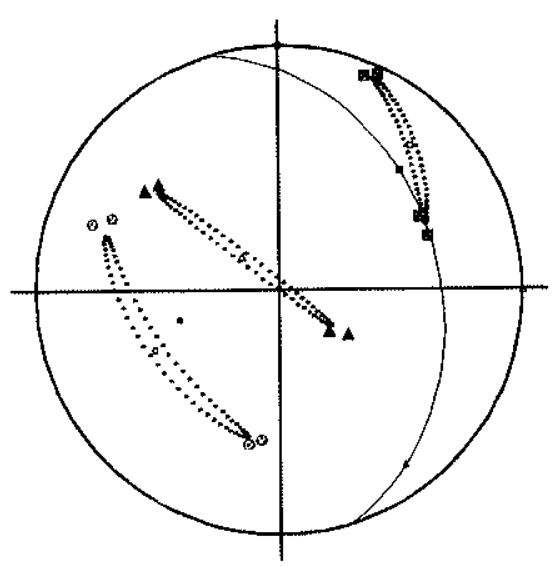

SITIO 21

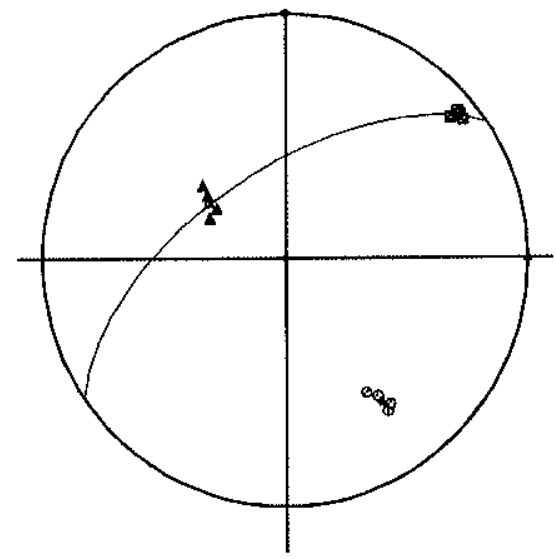

SITIO 23
- $\mathrm{K} 1$

- $\mathrm{K} 2$

- K3
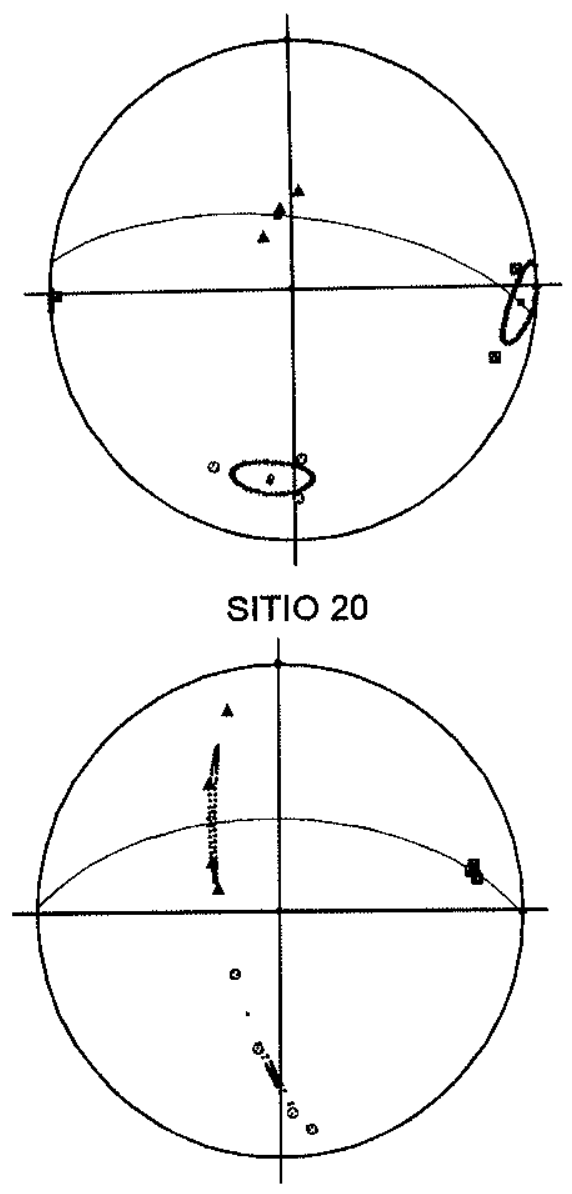

SITIO 22

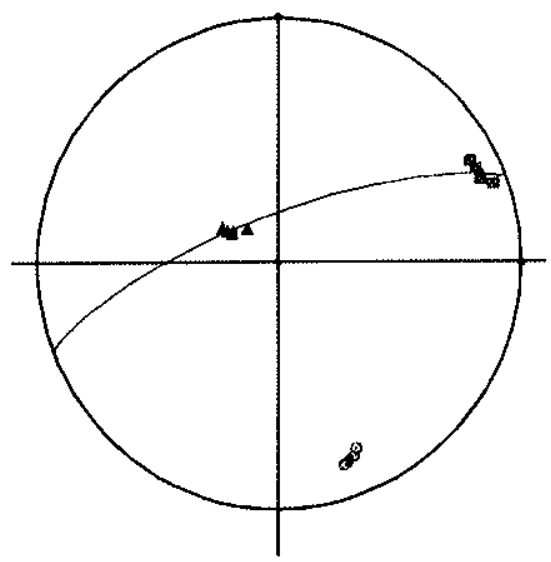

SITIO 24 
ASM DO PLUTÃO DE MARCABELLI, COMPLEXO

METAMÓRFICO DE EL ORO, EQUADOR

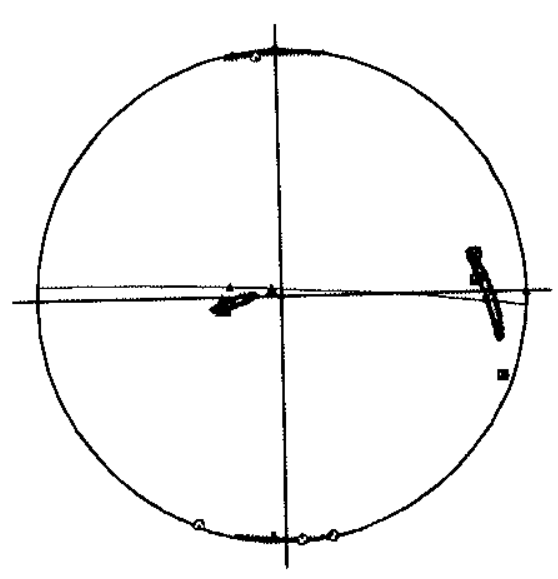

- $\mathrm{K} 1$
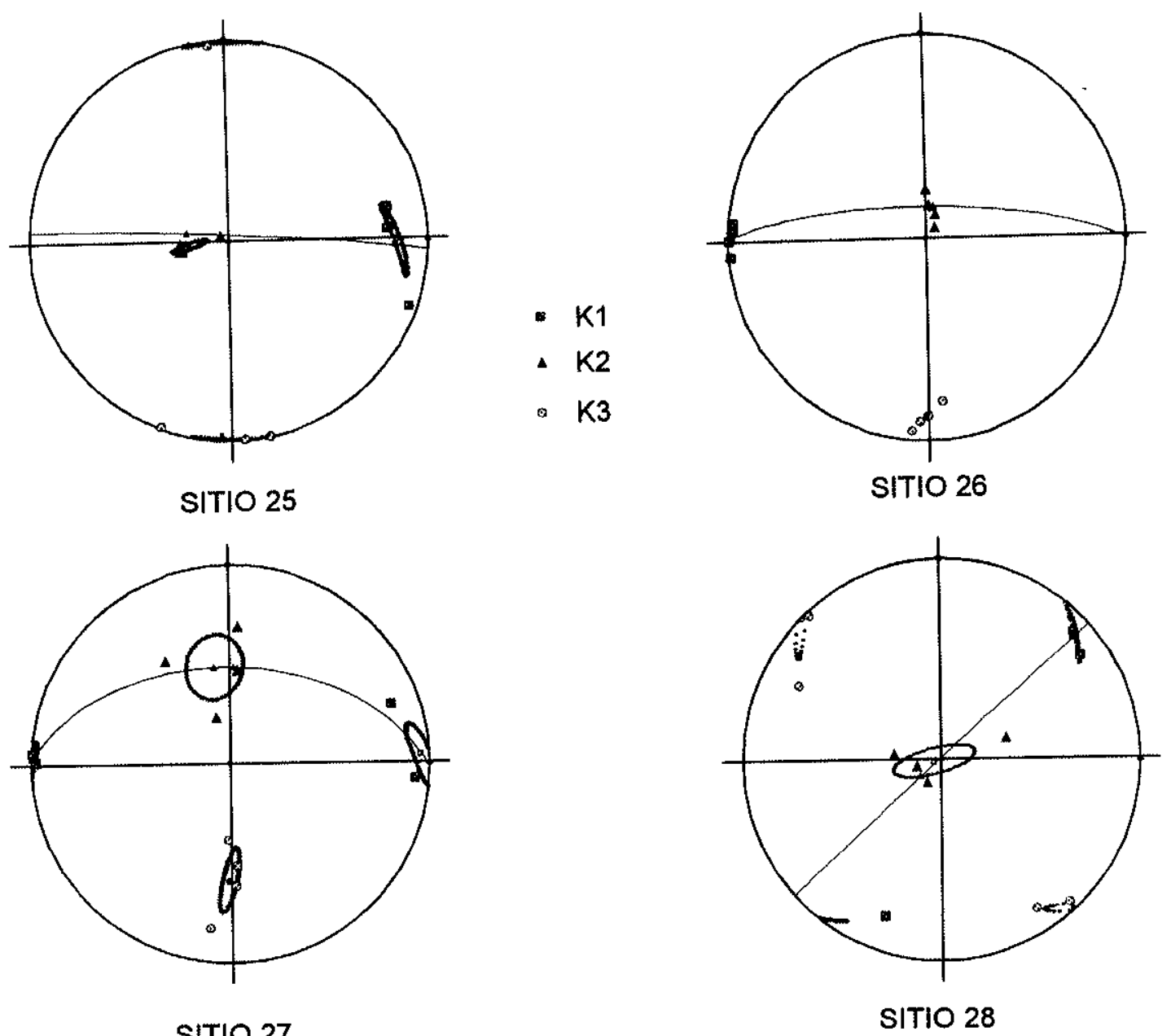

SITIO 27 


\section{ANEXO 2}

Anisotropia de Suscetibilidade Magnética média para o plutăo de Marcabell

\begin{tabular}{|c|c|c|c|c|c|c|c|c|c|}
\hline \multirow[b]{2}{*}{ Sitio } & \multicolumn{2}{|c|}{ UTM } & \multicolumn{3}{|c|}{ Dados escalares } & \multicolumn{4}{|c|}{ Dados direcionais } \\
\hline & $\mathbf{N}$ & $E$ & $\mathrm{Km}(\mathrm{SI}) \times 10^{-5}$ & $\mathbf{P}^{\prime}$ & $\mathbf{T}$ & $\mathbf{K}_{\mathbf{1}}$ & $K_{2}$ & $K_{3}$ & $\mathbf{a}_{1} / \mathbf{a}_{3}$ \\
\hline 1 & 957690 & 61880 & 19,14 & 1,36 & $-0,181$ & 346,43 & 78,1 & 169,47 & $28 / 33$ \\
\hline 2 & 958215 & 62075 & 248,31 & 1,09 & 0,287 & 246,9 & 356,64 & 152,23 & $7.0 / 5$ \\
\hline 3 & 957710 & 61655 & 29,13 & 1,04 & 0,238 & 198,20 & 294,16 & 61,64 & $32 / 25$ \\
\hline 4 & 957690 & 61590 & 35,09 & 1,06 & 0,290 & 200,21 & 344,65 & 104,13 & $32 / 29$ \\
\hline 5 & 957780 & 61815 & 107,39 & 1,05 & $-0,201$ & 105,28 & 241,54 & 3,21 & $23 / 42$ \\
\hline 6 & 957720 & 61760 & 109,51 & 1,05 & $-0,293$ & 59,7 & 155,38 & 320,51 & $4.0 / 16$ \\
\hline 7 & 957835 & 61905 & 26,90 & 1,07 & $-0,147$ & 68,16 & 336,8 & 221,72 & $21 / 24$ \\
\hline 8 & 957875 & 61932 & 47,49 & 1,06 & $-0,050$ & 198,11 & 105,10 & 335,74 & $32 / 33$ \\
\hline 9 & 958050 & 61880 & 233,52 & 1,04 & $-0,162$ & 63,5 & 328,40 & 159,49 & $6.0 / 14$ \\
\hline 10 & 957980 & 61892 & 116,84 & 1,05 & 0,069 & 75,8 & 166,10 & 263,82 & $15 / 14$ \\
\hline 11 & 958115 & 61935 & 188,63 & 1,06 & $-0,263$ & 250,3 & 350,72 & 159,17 & $16 / 25$ \\
\hline 12 & 958075 & 62040 & 55,04 & 1,07 & $-0,181$ & $281,0.4$ & 191,40 & 11,50 & $22 / 26$ \\
\hline$\uparrow 3$ & 957910 & 62080 & 32,72 & 1,04 & $-0,247$ & 271,18 & 11,28 & 152,56 & $35 / 37$ \\
\hline 14 & 958089 & 62252 & 135,97 & 1,11 & 0,043 & 50,18 & 284,61 & 147,22 & $4.0 / 7$ \\
\hline 15 & 958315 & 62400 & 237,58 & 1,14 & 0,348 & 91,12 & 333,66 & 186,20 & $8.0 / 9$ \\
\hline 16 & 958350 & 62505 & 178,43 & 1,09 & 0,335 & 72,14 & 309,65 & 167,20 & $4.0 / 4$ \\
\hline 17 & 958400 & 62719 & 167,02 & 1,13 & 0,443 & 75,20 & 308,52 & 174,23 & $3.0 / 2$ \\
\hline 18 & 958352 & 62666 & 174,96 & 1,11 & 0,211 & 123,21 & 359,56 & 223,25 & $7.0 / 6$ \\
\hline 19 & 958264 & 62600 & 167,42 & 1,05 & 0,093 & 65,30 & 257,59 & 158,5 & $13 / 20$ \\
\hline 20 & 958345 & 62555 & 183,02 & 1,11 & 0,107 & 94,7 & 349,65 & 187,24 & $11.0 / 11$ \\
\hline 21 & 958486 & 62774 & 155,46 & 1,06 & $-0,705$ & 46,31 & 144,13 & 254,55 & $25 / 42$ \\
\hline 22 & 958474 & 62938 & 192,20 & 1,09 & $-0,578$ & 79,19 & 322,53 & 181,30 & $1.0 / 24$ \\
\hline 23 & 958344 & 63055 & 153,64 & 1,11 & $-0,192$ & 51,9 & 306,59 & 146,30 & $2.0 / 4$ \\
\hline 24 & 958585 & 63295 & 181,40 & 1,10 & 0,110 & 67,10 & 306,71 & 160,16 & $3.0 / 3$ \\
\hline 25 & 958590 & 63715 & 164,66 & 1,10 & $-0,004$ & 92,18 & 281,72 & 183,3 & $13 / 12$ \\
\hline 26 & 958591 & 63536 & 250,41 & 1,10 & $-0,104$ & 271,3 & 13,77 & 181,13 & $4.0 / 6$ \\
\hline 27 & 958352 & 63216 & 236,42 & 1,06 & 0,291 & $272,0.3$ & 2,50 & 181,40 & $11.0 / 15$ \\
\hline 28 & 958648 & 64172 & $3+1,16$ & 1,15 & $-0,065$ & 48,10 & 232,80 & $138,0.6$ & $18 / 16$ \\
\hline
\end{tabular}

$a_{1} / a_{3}=$ cone de confiança para $\mathrm{K} 1$ e $\mathrm{K} 3$ respectivamente a 1 -sigma 


\section{ANEXO 3}

Tabela resumo dos dados da OPF para o plutăo de Marcabelí

\begin{tabular}{|c|c|c|c|c|c|c|c|}
\hline & $F^{1 / 2}(\%)$ & $\mathrm{C}$ & Flinn & $P^{\prime}$ & $T$ & $a_{1}$ & RS \\
\hline \multicolumn{8}{|l|}{ EQ-5a } \\
\hline Intercepto & $3,2212.8 / 49.5$ & $106.1 / 146$ & 0,735 & 1,251 & 0,145 & 11,1 & 1,25 \\
\hline M.Tensorial & $7,4213.7 / 55.9$ & $95.3 / 17.6$ & 1,032 & 1,622 & $-0,014$ & 9,5 & 1,618 \\
\hline M. Tensorial elip. & $4,6 \quad 185.2 / 36.2$ & $93.2 / 2.9$ & 1,026 & 1,284 & $-0,012$ & 6,2 & 1,283 \\
\hline M. Tensorial norm. & $4,5195.5 / 36$ & $94.8 / 13.4$ & 0,457 & 1,385 & 0,348 & 17,1 & 1,376 \\
\hline \multicolumn{8}{|l|}{ EQ-6a } \\
\hline Intercepto & $3,9292.8 / 73.2$ & $75.5 / 9.7$ & 0,618 & 1,138 & 0,229 & 25 & 1,137 \\
\hline M.Tensorial & $6,8348.1 / 62.1$ & $90.3 / 7.8$ & 0,788 & 1,336 & 0,11 & 14,2 & 1,335 \\
\hline M. Tensorial elip. & $6,2354.8 / 64.2$ & $299.2 / 15.2$ & 2,166 & 1,129 & $-0,359$ & 18,8 & 1,126 \\
\hline M. Tensorial norm. & $3,3336.3 / 69.7$ & $105.6 / 15.1$ & 2,231 & 1,195 & $-0,367$ & 6,4 & 1,19 \\
\hline \multicolumn{8}{|l|}{ EQ-9 } \\
\hline Intercepto & $2,5321.7 / 83.5$ & $73.3 / 2$ & 0,296 & 1,223 & 0,525 & 19,3 & 1,212 \\
\hline M.Tensorial & $10326.7 / 73.7$ & $70.6 / 5.7$ & 0,808 & 1,429 & 0,098 & 27,3 & 1,427 \\
\hline M. Tensorial elip. & $5,2268.4 / 66.3$ & $67 / 24.9$ & 0,295 & 1,16 & 0,531 & 32,7 & 1,152 \\
\hline M. Tensorial norm. & $4,8318.2 / 74.6$ & $74.4 / 67$ & 0,182 & 1,287 & 0,671 & 31,8 & 1,265 \\
\hline \multicolumn{8}{|l|}{ EQ-10 } \\
\hline Intercepto & $3,8240.7 / 67.3$ & $59.7 / 22.1$ & 0,811 & 1,237 & 0,099 & 9,6 & 1,237 \\
\hline M.Tensorial & $9,6220.8 / 62$ & $58.6 / 19.4$ & 0,392 & 1,434 & 0,407 & 28,8 & 1,419 \\
\hline M. Tensorial elip. & $9,1238 / 42.3$ & $64 / 18.7$ & 3,425 & 1,173 & $-0,534$ & 23,7 & 1,164 \\
\hline M. Tensorial norm. & $6,8247.2 / 65.2$ & $69.6 / 23.8$ & 0,428 & 1,364 & 0,376 & 18,9 & 1,353 \\
\hline \multicolumn{8}{|l|}{ EQ-11 } \\
\hline Intercepto & $2,4149.6 / 26.4$ & $57.5 / 4$ & 0,746 & 1,288 & 0,137 & 3 & 1,287 \\
\hline M.Tensorial & $14,4 \quad 150.7 / 59$ & $58.5 / 1$ & 0,323 & 1,59 & 0,471 & 20,6 & 1,562 \\
\hline M. Tensorial elip. & $9,5155.8 / 41.4$ & $52.3 / 11.7$ & 2,564 & 1,376 & $-0,412$ & 9,2 & 1,363 \\
\hline M. Tensorial norm. & $8156.7 / 39.5$ & $56.2 / 6.3$ & 0,869 & 1,47 & 0,064 & 12,3 & 1,468 \\
\hline \multicolumn{8}{|l|}{ EQ-14 } \\
\hline M.Tensorial & $5,940.9 / 14.5$ & $133.6 / 5.7$ & 0,666 & 1,54 & 0,181 & 12,7 & 1,534 \\
\hline M. Tensorial elip. & $12,931.8 / 5.6$ & $124.8 / 3.6$ & 1,124 & 1,647 & $-0,052$ & 8,1 & 1,642 \\
\hline M. Tensorial norm. & $15,937.1 / 6.3$ & $299.7 / 34.2$ & 0,695 & 1,248 & 0,171 & 20,4 & 1,247 \\
\hline \multicolumn{8}{|l|}{ EQ-15 } \\
\hline Intercepto & $1,4184.6 / 34.5$ & $85.9 / 12.5$ & 3,228 & 1,569 & $-0,486$ & 1,7 & 1,54 \\
\hline M.Tensorial & $2,6 \quad 185.5 / 34.7$ & $86.2 / 13.3$ & 14,917 & 9,66 & $-0,738$ & 0,7 & 6,705 \\
\hline M. Tensorial elip. & $4,9188.2 / 34.9$ & $84.9 / 18.2$ & 3,331 & 2,047 & $-0,475$ & 2,3 & 1,98 \\
\hline M. Tensorial norm. & $2,7186.7 / 34.3$ & $86.9 / 14$ & 4,617 & 2,799 & $-0,552$ & 1,3 & 2,68 \\
\hline \multicolumn{8}{|l|}{ EQ-17 } \\
\hline Intercepto & $3,763.8 / 34.2$ & $170.9 / 23.3$ & 0,852 & 1,432 & 0,073 & 3,5 & 1,43 \\
\hline M.Tensorial & $19,970.8 / 33.6$ & $193.1 / 40.5$ & 0,82 & 1,72 & 0,087 & 19,7 & 1,713 \\
\hline M. Tensorial elip. & $10,767.1 / 26.5$ & $169.3 / 34.2$ & 0,907 & 1,292 & 0,046 & 18,7 & 1,291 \\
\hline M. Tensorial norm. & $4,668.2 / 23.7$ & $168 / 21.2$ & 0,603 & 0,016 & 0,222 & 7,6 & 1,607 \\
\hline \multicolumn{8}{|l|}{ EQ-26 } \\
\hline Intercepto & $4284.4 / 5.9$ & $14.5 / 0.8$ & 0,501 & 1,419 & 0,308 & 1,5 & 1,41 \\
\hline M.Tensorial & $10,5280.8 / 12.8$ & $11.2 / 0.4$ & 0,658 & 2,469 & 0,168 & 8,1 & 2,426 \\
\hline M. Tensorial elip. & $6,6105.3 / 51.2$ & $22 / 0.3$ & 1,553 & 1,296 & $-0,204$ & 9,5 & 1,294 \\
\hline M. Tensorial norm. & $9,5103.9 / 11.5$ & $194.6 / 4$ & 0,385 & 1,404 & 0,416 & 9,8 & 1,39 \\
\hline
\end{tabular}

$\mathrm{F}^{1 / 2}(\%)=$ indice de incompatibilidade

RS = razăo axial da elipsede distribuição dos grãos

$a_{1}=$ valor do cone de confiança para A a 1-sigma 


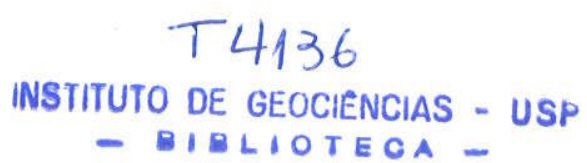

ENCARTE 1. Mapa geológico simplificado dos Andes do Norte e corpos com idades Triássicas na zona de estudo

LEGENDA

Rochas Cenozoicos e Quatemárias

ㅁ. Rochas vulcânicas básicas Mesozoicas e Cenozoicas

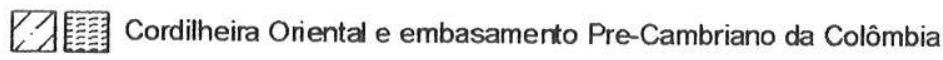

Magmatismo Cretácico

-7 Plutonismo Jurássico

- Embasamento Paleozóico da Cordilhiera Central da Colômbia Serra Nevada de Santa Marta e terreno Loja no Equador

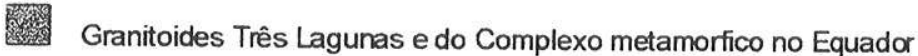

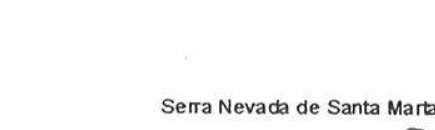

Peninsula da Guajira

Sera Nevada de Sant
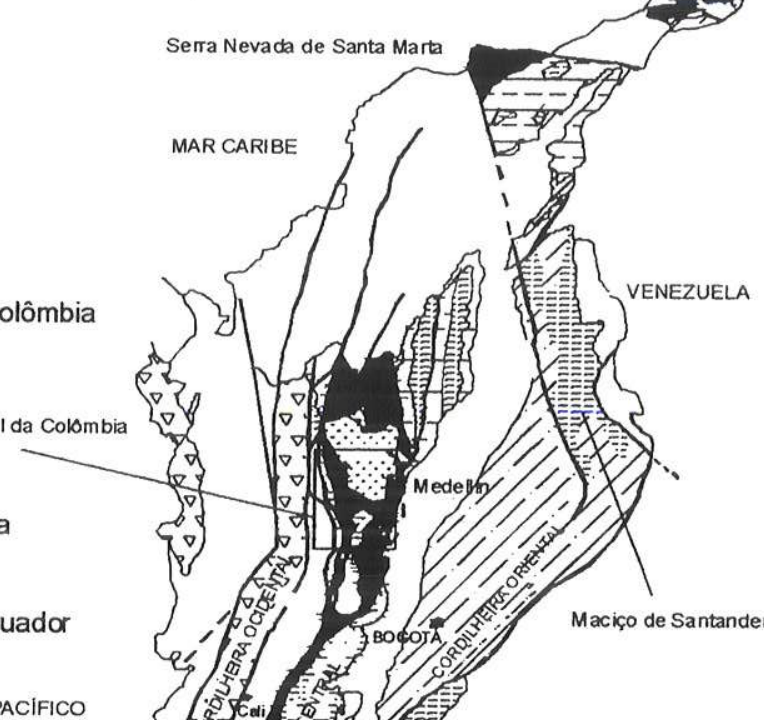

OCEANO PACIFICO

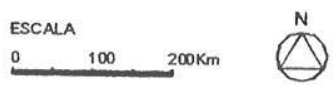

(Tomado e modifícado deToussaint, 1993 INGEOMINAS, 1988 e Litherland 1994)

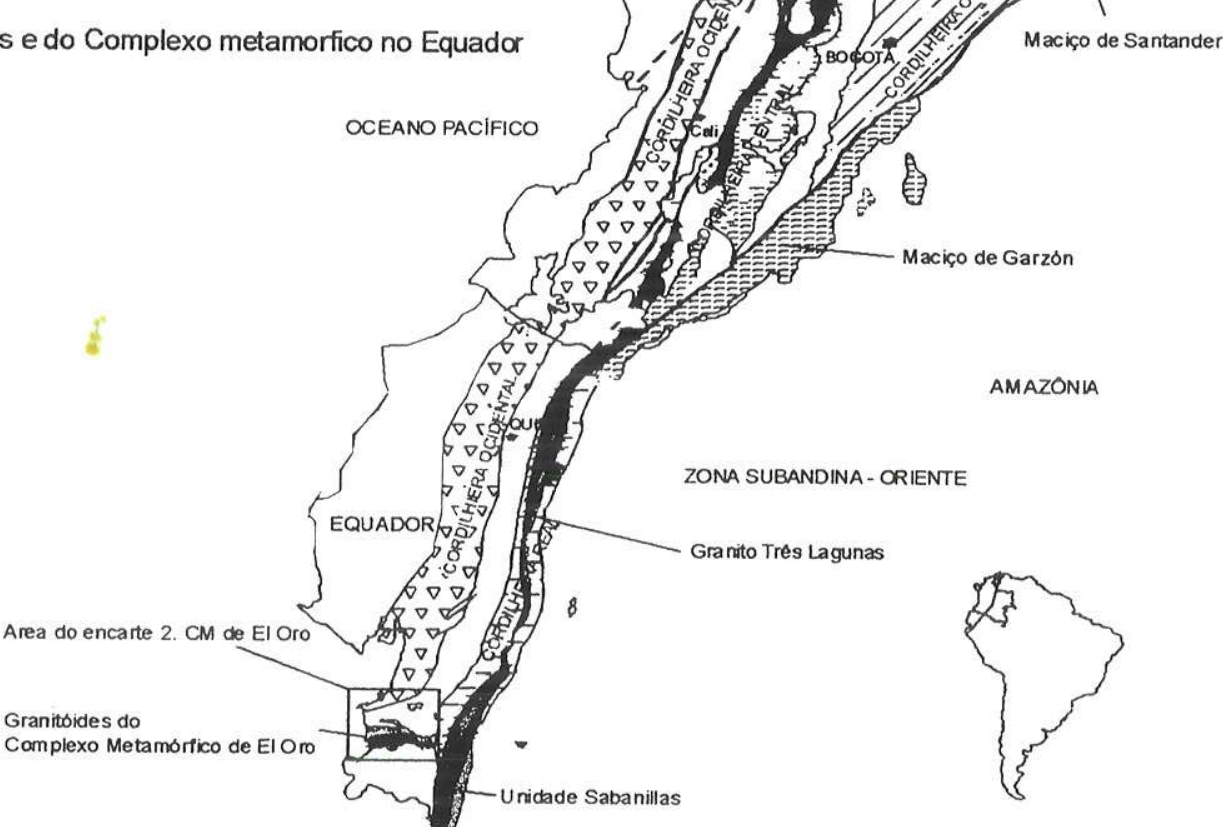




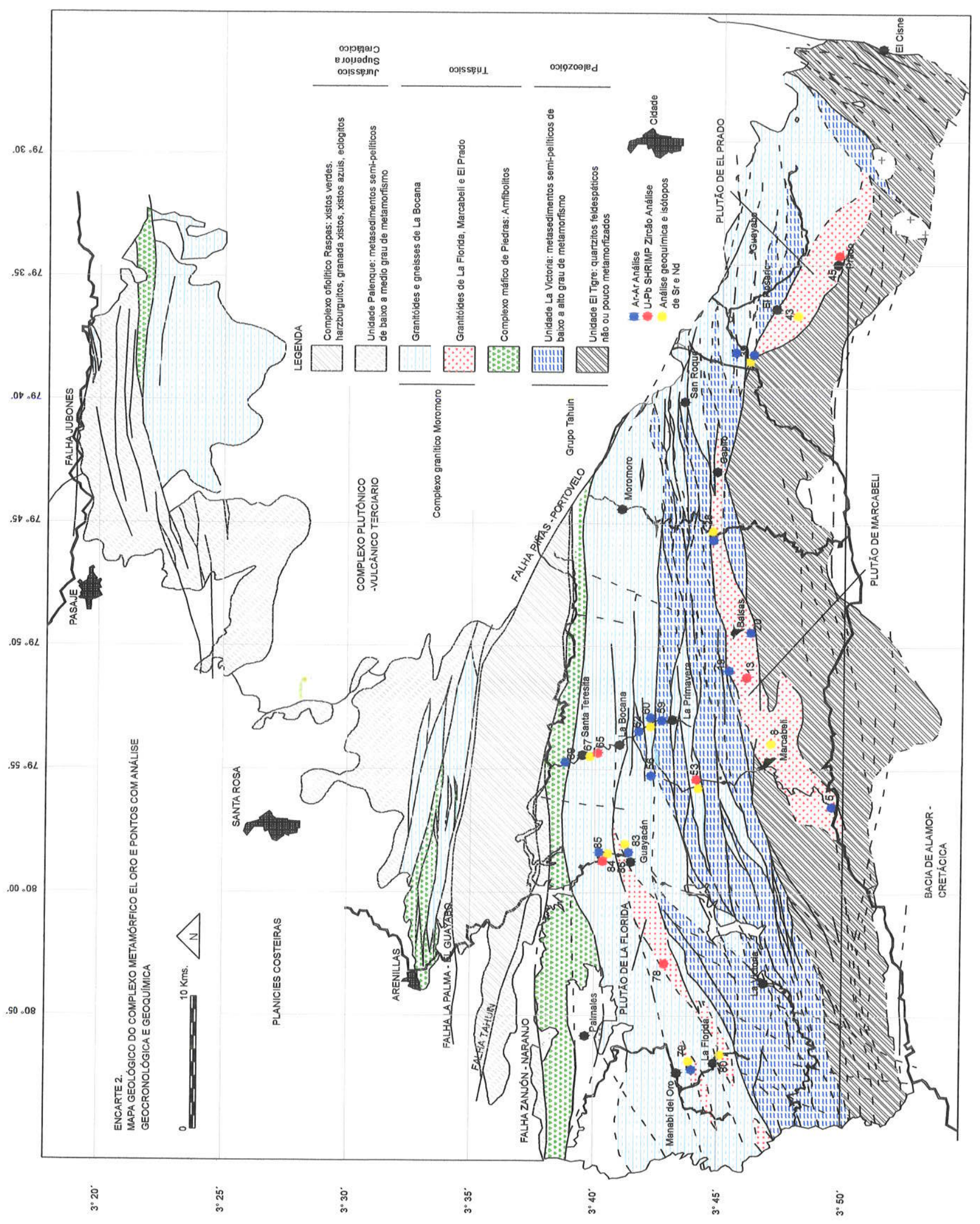




$$
T 4136
$$

INSTITUTO DE GEOCIENCIAS - USP

- B.BLIOTECA

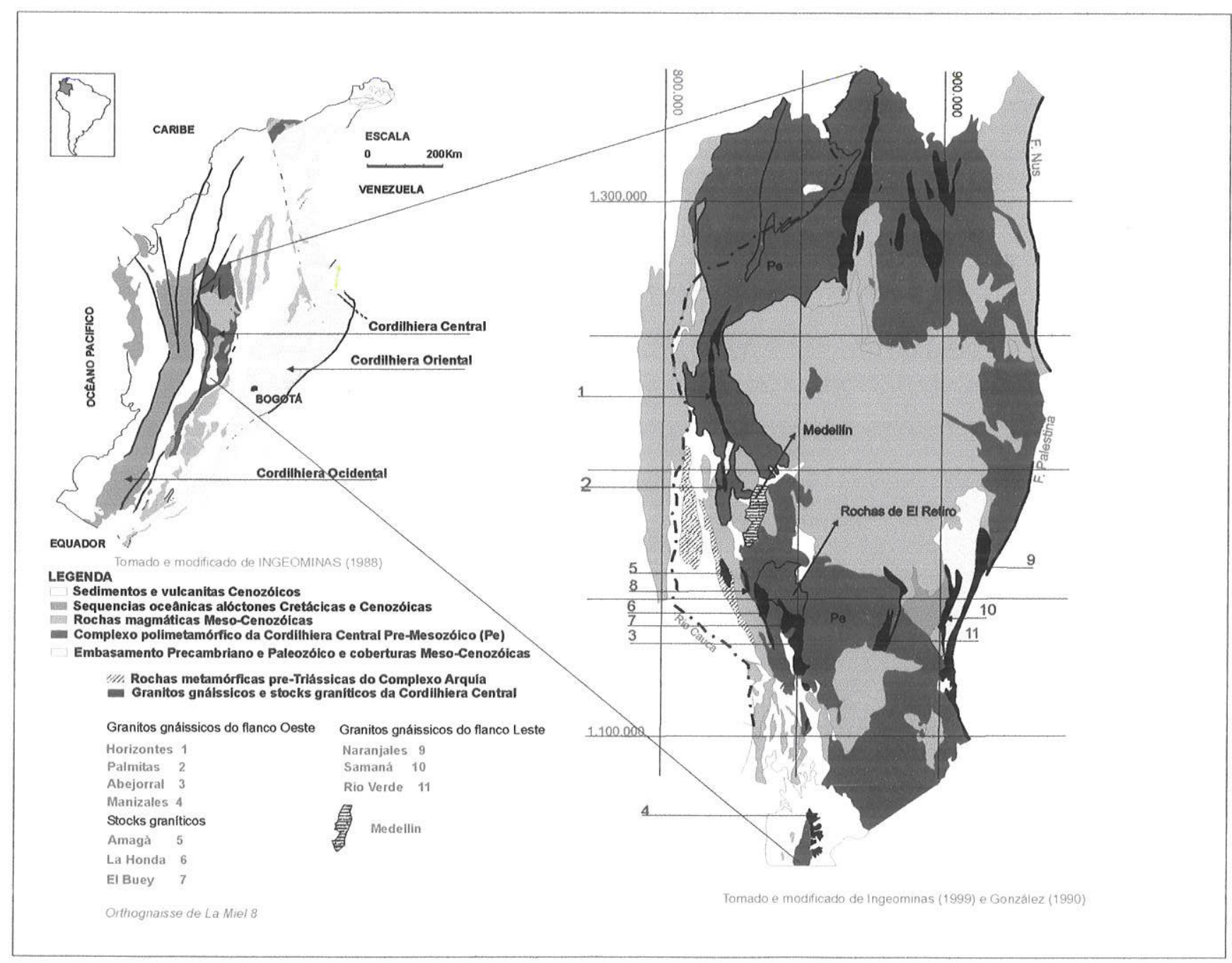

Encarte 3. Mapa geológico da Colômbia e detalhe da parte norte da Cordilhiera Central com a localização dos corpos em estudo. 
ENCARTE 4. Dados Geocronológicos Pre-cretácicos da Cordilheira Central da Colômbia

\begin{tabular}{|c|c|c|c|}
\hline Unidade & Método & Idade & Referência \\
\hline OrtoGneiss de La Miel & $\mathrm{K}-\mathrm{Ar} / \mathrm{Bi}$ & $343 \pm 12$ & Restrepo e Toussaint, 1978 \\
\hline OrtoGneiss de La Miel & $\mathrm{K}-\mathrm{Ar} / \mathrm{Bi}$ & 340 & Restrepo et al., 1991 \\
\hline Gneiss de Puquí & $\mathrm{K}-\mathrm{Ar} / \mathrm{Bi}$ & $285 \pm 12$ & Restrepo et al., 1991 \\
\hline Gneiss de Puquí & $\mathrm{K}-\mathrm{Ar} / \mathrm{Bi}$ & $254 \pm 10$ & Toussaint et al., 1978 \\
\hline Gneiss de Puquí & $\mathrm{K}-\mathrm{Ar} / \mathrm{Bi}$ & $248 \pm 10$ & Toussaint et al., 1978 \\
\hline Metatonalito de Puqui & $\mathrm{K}-\mathrm{Ar} / \mathrm{Mu}$ & $214 \pm 7$ & Hall et al., 1972 \\
\hline Metatonalito de Puqui & $\mathrm{K}-\mathrm{Ar} / \mathrm{Bi}$ & $239 \pm 7$ & Hall et al., 1972 \\
\hline Metatonalito de Puqui & $\mathrm{K}-\mathrm{Ar} / \mathrm{Bi}$ & $211-220$ & Botero, 1975 \\
\hline Gneiss granítico de Norcasia & $\mathrm{K}-\mathrm{Ar} / \mathrm{Bi}$ & $205 \pm 7$ & Vesga e Barrero, 1978 \\
\hline Gneiss de Abejorral & $\mathrm{K}-\mathrm{Ar} / \mathrm{Bi}$ & $207 \pm 5$ & González; 1980 \\
\hline Gneiss granítico de Palmitas & $\mathrm{K}-\mathrm{Ar} / \mathrm{Bi}$ & $96 \pm 5$ & Restrepo et al., 1991 \\
\hline Xistos Compiexo Pol. C. Central & K-Ar/RT & $270 \pm 10$ & Restrepo et al., 1978 \\
\hline Xistos Complexo Pol. C.Central & $\mathrm{K}-\mathrm{Ar} / \mathrm{RT}$ & $182 \pm 8$ & Restrepo et al., 1991 \\
\hline Xistos Complexo Pol. C. Central & $\mathrm{K}-\mathrm{Ar} / \mathrm{RT}$ & $160 \pm 11$ & Restrepo et al., 1991 \\
\hline Anfibolito de Caldas & K-Ar/Anf & $264 \pm 27$ & Restrepo et al., 1991 \\
\hline Anfibolito de Caldas & K-Ar/Anf & $254 \pm 8$ & Restrepo et al., 1991 \\
\hline Granulito G. El Retiro & $\mathrm{K}-\mathrm{Ar} / \mathrm{RT}$ & $251 \pm 21$ & Restrepo et al., 1991 \\
\hline Migmatito de Pte. Peláez & $\mathrm{K}-\mathrm{Ar} / \mathrm{Bi}$ & $110 \pm 10$ & Restrepo et al., 1978 \\
\hline Anfibolito de Padua & K-Ar/Anf & $231 \pm 10$ & Vesga e Barrero, 1978 \\
\hline Anfibolito de Padua & K-Ar/Anf & $226 \pm 10$ & Vesga e Barrero, 1978 \\
\hline Granito del Buey & $\mathrm{K}-\mathrm{Ar} / \mathrm{Bi}$ & $227 \pm 10$ & González et al., 1978 \\
\hline Granito de Amagá & $\mathrm{K}-\mathrm{Ar} / \mathrm{Bi}$ & $215 \pm 7$ & Perez, 1967 \\
\hline Gneiss de Horizontes & $\mathrm{Ar}-\mathrm{Ar} / \mathrm{Ms}$ & 207 & Vinasco, 2001 \\
\hline Gneiss de Abejorral & $\mathrm{Ar} / \mathrm{Ar} / \mathrm{Bi}$ & 230 & Vinasco, 2001 \\
\hline Anfibolita del Retiro & $\mathrm{Ar} / \mathrm{Ar}$ & 230 & Vinasco, 2001 \\
\hline La Honda & $\mathrm{Ar}-\mathrm{Ar} / \mathrm{Bt}$ & 218 & Vinasco, 2001 \\
\hline Granito del Buey & A-Ar/Ms & 219 & Vinasco, 2001 \\
\hline OrtoGneiss de La Miel & s. Rb-SrRT & $388 \pm 12$ & Restrepo et al., 1991 \\
\hline OrtoGneiss de Samaná & Is. Rb-Sr RT & $346 \pm 26$ & Restrepo e Toussaint, 1982 \\
\hline Gneiss de Puqui & 1s. Rb-SrRT & $306 \pm 11$ & Ordoñez e Pimentel, 2002. \\
\hline Metatonalito de Puqui & is. Rb-SrRT & $248 \pm 17$ & Ordoñez y Pimentel, 2002 \\
\hline Granito de Amagá & is. Rb-Sr RT & 308 & Restrepo et al., 1991 \\
\hline Gneiss de Pescadero & Is. Rb-SrRT & $253 \pm 10$ & Restrepo et al., 1991 \\
\hline Gneiss das Palmas & Is. Rb-Sr RT & 167 & Restrepo et al., 1991 \\
\hline Xistos Complexo Pol. C.Central & Is. Rb-Sr RT & $226 \pm 4$ & Restrepo et al., 1991 \\
\hline Gneiss G. Ayurá Montebello & $\mathrm{Rb}-\mathrm{Sr} / \mathrm{Bi}$ & 69 & Fujiyoshi et al., 1976 \\
\hline Granito de Amagá & Is. Rb-Sr RT & $203 \pm 5$ & Faure, 1978 \\
\hline Migmatitos G. El Retiro & Is. Rb-Sr RT & 238 & Restrepo et al., 1991 \\
\hline Gneiss granitico de Palmitas & Is. Rb-Sr RT & $155 \pm 25$ & Ordoñez, 2001 \\
\hline Gneiss granítico de Palmitas & Is. Rb-SrRT & $173 \pm 26$ & Ordoñez, 2001 \\
\hline Granulito G. El Retiro & $\mathrm{Sm} / \mathrm{Nd} \mathrm{RT}$ & $226 \pm 17$ & Correa e Martens, 2000 \\
\hline Gneiss das Palmas & $\mathrm{U}-\mathrm{Pb} / \mathrm{Zr}$ & $252 \pm 10$ & Ordoñez, 2001 \\
\hline Gneiss das Palmas & $\mathrm{U}-\mathrm{Pb} / \mathrm{Zr}$ & $295 \pm 7$ & Ordoñez, 2001 \\
\hline Gneiss das Palmas & $\mathrm{U}-\mathrm{Pb} / \mathrm{Zr}$ & $230 \pm 5$ & Ordoñez, 2001 \\
\hline
\end{tabular}




\begin{tabular}{|c|c|c|c|c|c|c|c|c|c|c|c|c|c|c|c|c|}
\hline \multicolumn{17}{|c|}{$\begin{array}{l}\text { Encarte 5. Dados isotópicos Nd-Sr para Intrusivos Permo-Triássicos dops Andes do } \\
\text { Norte. }\end{array}$} \\
\hline & & No Campo & $\mathrm{Sm}$ & $\mathrm{Nd}$ & ${ }^{147} \mathrm{Sm}, I^{144 \mathrm{Nd}}$ & ${ }^{143} \mathrm{Nd} / 144 \mathrm{Nd}$ & $f_{\text {smNd }}$ & $\varepsilon_{\text {No(T) }}$ & TOM & $\mathrm{Rb}$ & $\mathrm{Sr}$ & $87 \mathrm{Rb}^{86 \mathrm{Sr}}$ & ${ }^{87} \mathrm{Sr} r^{88} \mathrm{Sr}$ & $\varepsilon_{s(\pi)}$ & ${ }^{87} \mathrm{Sr}, 88 \mathrm{Sr}$ & Idade (Ma) \\
\hline & COLÔMBIA & & (ppm) & (ppm) & & & & & (Ga) & (ppm) & (ppm) & & & $\therefore \quad \theta$ & inicial & Tc \\
\hline \multirow{9}{*}{ 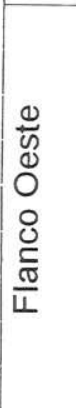 } & Gneisse Palmitas & cjv01 & 6,041 & 26,895 & 0,1358 & 0,512218 & $-0,31$ & $-6,2$ & 1,53 & 74,3 & 194,00 & 1,110 & 0,7170 & 126 & 0,7131 & 250 \\
\hline & Gneisse Horizontes & cjv12 & 7,696 & 30,342 & 0,1534 & 0,512332 & $-0,22$ & $-4,6$ & 1,40 & 113,4 & 237,20 & 1,384 & 0,7133 & 59 & 0,7084 & 250 \\
\hline & Gneisse Abejorral & cj32 & 6,681 & 31,861 & 0,1268 & 0,512193 & $-0,36$ & $-6,4$ & 1,54 & 115,1 & 199,50 & 1,671 & 0,7149 & 67. & 0,7089 & 250 \\
\hline & Gneisse Manizales & $\operatorname{col} 4$ & 6,225 & 22,634 & 0,1663 & 0,512229 & $-0,15$ & $-7,0$ & 1,58 & 110,4 & 174,90 & 1,828 & 0,7159 & 74 & 0,7094 & 250 \\
\hline & Gneisse La Miel(2) & col69 & 6,434 & 22,672 & 0,1716 & 0,512173 & $-0,13$ & $-7,8$ & 1,74 & 155,8 & 64,10 & 7,066 & 0,7610 & 238 & 0,7208 & 400 \\
\hline & Granitoide La Honda(3) & VRE-17-MA & 3,799 & 16,899 & 0,1359 & 0,512359 & $-0,31$ & $-3,6$ & 1,32 & 119,5 & 139,06 & 2,489 & 0,7182 & 83 & 0,7101 & 230 \\
\hline & Granitoide La Honda (3) & VRE-17-MB & 2,282 & 8,867 & 0,1556 & 0,512337 & $-0,21$ & $-4,7$ & 1,40 & 122,7 & 188,79 & 1,883 & 0,7175 & 101 & 0,7113 & 230 \\
\hline & Granitoide Amaga (3) & VRE-6A & 5,405 & 22,878 & 0,1429 & 0,512396 & $-0,27$ & $-3,1$ & 1,28 & 136,9 & 163,35 & 2,429 & 0,7239 & 167 & 0,7160 & 230 \\
\hline & Granitoide Amaga (4) & UN-4525* & 5,463 & 21,753 & 0,1519 & 0,512508 & $-0,23$ & $-1,2$ & 1,13 & 140,1 & 55,21 & 7,364 & 0,7351 & 96 & 0,7110 & 230 \\
\hline \multirow{6}{*}{ 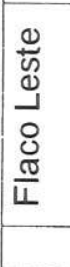 } & Ortogneisse Rio Verde (5) & INV-8640 & 5,876 & 29,168 & 0,1218 & 0,512095 & $-0,38$ & $-8,2$ & 1,67 & 125,9 & 95,40 & 3,825 & 0,7221 & 76 & 0,7096 & 250 \\
\hline & & IGM-80076 & 6,813 & 32,792 & 0,1256 & 0,512215 & $-0,36$ & $-6,0$ & 1,51 & 97,3 & 193,28 & 1,458 & 0,7201 & 158 & 0,7153 & 250 \\
\hline & & INV-8381 & 8,320 & 41,224 & 0,1220 & 0,512206 & $-0,38$ & $-6,1$ & 1,51 & 79,4 & 170,95 & 1,346 & 0,7170 & 119 & 0,7126 & 250 \\
\hline & Ortogneisse Samana & INV-8134(5) & 4,236 & 18,845 & 0,1359 & 0,512378 & $-0,31$ & $-3,1$ & 1,29 & 168,8 & 151,13 & 3,235 & 0,7130 & -25 & 0,7025 & 250 \\
\hline & & INV-8133(5) & 5,120 & 25,960 & 0,1193 & 0,512062 & $-0,39$ & $-8,8$ & 1,71 & 4,8 & 202,66 & 0,068 & 0,7313 & 381 & 0,7311 & 250 \\
\hline & EQUADOR & & & & & & & & & & & & & & & \\
\hline \multirow{11}{*}{ 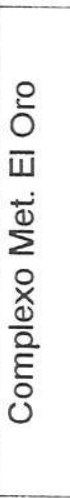 } & Granitoide Marcabeli & cvin 8 & 3,395 & 15,203 & 0,1350 & 0,512350 & $-0,31$ & $-3,6$ & 1,33 & 108,2 & 128,64 & 2,438 & 0,7178 & 70 & 0,7091 & 250 \\
\hline & Granitoide Marcabeli (Mto) & cvin 29 & 9,142 & 45,069 & 0,1227 & 0,512047 & $-0,38$ & $-9,2$ & 1,73 & 163,4 & 119,68 & 3,960 & 0,7331 & 210 & 0,7190 & 250 \\
\hline & Granitoide El Prado & cvin 39 & 6,059 & 28,421 & 0,1289 & 0,512154 & $-0,34$ & $-7,3$ & 1,60 & 154,6 & 103,60 & 4,328 & 0,7273 & 110 & 0,7119 & 250 \\
\hline & Granitoide El Prado & cvin 43 & 7,237 & 33,444 & 0,1309 & 0,512328 & $-0,33$ & $-3,9$ & 1,36 & 157,1 & 131,04 & 3,476 & 0,7264 & 139 & 0,7140 & 250 \\
\hline & Granitoide La Florida & cvin 79 & 10,002 & 45,507 & 0,1329 & 0,512252 & $-0,32$ & $-5,5$ & 1,47 & 190,0 & 154,25 & 3,570 & 0,7254 & 121 & 0,7127 & 250 \\
\hline & Granitoide La Florida & cvin 80 & 7,865 & 37,172 & 0,1279 & 0,512277 & $-0,35$ & $-4,8$ & 1,42 & 141,9 & 140,00 & 2,938 & 0,7214 & 96 & 0,7110 & 250 \\
\hline & Granitoide La Bocana & Cvin 83 & 7,142 & 33,674 & 0,1282 & 0,512046 & $-0,35$ & $-9,4$ & 1,75 & 174,0 & 123,70 & 4,078 & 0,7215 & 40 & 0,7070 & 250 \\
\hline & Granitoide La Bocana & cvin 60 & 5,953 & 29,034 & 0,1240 & 0,512165 & $-0,37$ & $-6,9$ & 1,57 & 163,5 & 187,20 & 2,532 & 0,7210 & 110 & 0,7120 & 250 \\
\hline & Granitoide La Bocana & cvin 65 & 9,029 & 44,265 & 0,1233 & 0,512147 & $-0,37$ & $-7,2$ & 1,60 & & & & & & & 250 \\
\hline & La Bocana-Metased & cvin 84 & 7,199 & 27,116 & 0,1605 & 0,512714 & $-0,18$ & 2,6 & 0,81 & 143,9 & 171,00 & 2,438 & 0,7169 & 58 & 0,7083 & 250 \\
\hline & La Victoria-Metased & cvin 54 & 8,126 & 40,126 & 0,1225 & 0,511965 & $-0,38$ & $-10,8$ & 1,84 & 178,6 & 104,40 & 4,966 & 0,7414 & 277 & 0,7237 & 250 \\
\hline \multirow{4}{*}{$\begin{array}{l}\bar{\pi} \\
\otimes \\
\propto \\
ن\end{array}$} & Granitoide Sabanilla & sab02 & 1,518 & 8,169 & 0,1123 & 0,512197 & $-0,43$ & $-6,1$ & 1,50 & 104,9 & 130,10 & 2,337 & 0,7189 & 100 & 0,7113 & 230 \\
\hline & Granitoide Tres Lagunas & pap03 & 3,775 & 15,323 & 0,1490 & 0,512321 & $-0,24$ & $-4,8$ & 1,41 & 116,4 & 54,80 & 6,159 & 0,7229 & -21 & 0,7027 & 230 \\
\hline & Granitoide Tres Lagunas & ba03 & 5,222 & 24,434 & 0,1292 & 0,512280 & $-0,34$ & $-5,0$ & 1,42 & 159,6 & 34,30 & 13,490 & 0,7261 & -316 & 0,6820 & 230 \\
\hline & & & & \multicolumn{5}{|c|}{$\begin{array}{l}\text { (3) Samples from Vanessa Rios, U. Nacional, } \\
\text { Colombia }\end{array}$} & & & & & & & & \\
\hline \multicolumn{3}{|c|}{ (2) Sample from Andres Bustamante USP-Brazil } & & (4) Sample & es from $U . \mathrm{Na}$ & lacional, Color & mbia & & & \multicolumn{5}{|c|}{ (5) Samples from INGEOMINAS, Colombia. } & & \\
\hline
\end{tabular}




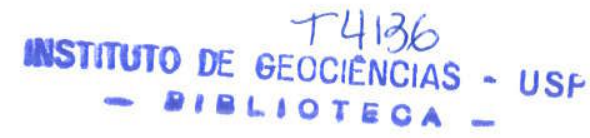

Encarte 6. Análises geoquímicas de granitos gnaissicos e stocks graníticos da C. Central .

$$
\begin{array}{lllllll}
\text { CJV-01 CJV-12 } & \text { CJV-32 } & \text { COL-04 } & \text { COL 69A COL-69 }
\end{array}
$$

\begin{tabular}{|c|c|c|c|c|c|c|}
\hline Flanco oeste & Palmitas & Horizontes & Abejorral & Manizales & La Miel & La Miel \\
\hline $\mathrm{SiO} 2$ & 73,68 & 66,08 & 69,90 & 69,40 & 71,7 & 72,99 \\
\hline $\mathrm{Al} 2 \mathrm{O} 3$ & 12,65 & 15,00 & 13,59 & 14,38 & 14,44 & 13,79 \\
\hline $\mathrm{MnO}$ & 0,048 & 0,068 & 0,050 & 0,066 & 0,027 & 0,030 \\
\hline $\mathrm{MgO}$ & 1,02 & 2,37 & 1,83 & 1,56 & 0,56 & 0,83 \\
\hline $\mathrm{Fe} 2 \mathrm{O} 3(\mathrm{~T})$ & 3,19 & 5,10 & 4,70 & 3,95 & 2,08 & 1,59 \\
\hline $\mathrm{CaO}$ & 1,93 & 2,82 & 1,15 & 1,70 & 0,17 & 0,23 \\
\hline $\mathrm{Na} 2 \mathrm{O}$ & 2,72 & 2,73 & 2,01 & 2,93 & 2,72 & 2,57 \\
\hline $\mathrm{K} 2 \mathrm{O}$ & 2,16 & 2,63 & 3,60 & 2,68 & 4,86 & 5,36 \\
\hline TiO2 & 0,520 & 0,931 & 0,715 & 0,534 & 0,276 & 0,239 \\
\hline P2O5 & 0,137 & 0,111 & 0,226 & 0,142 & 0,201 & 0,183 \\
\hline Loi & 0,99 & 1,40 & 1,54 & 1,71 & 1,51 & 1,42 \\
\hline Total & 99,05 & 99,24 & 99,31 & 99,05 & 98,71 & 99,23 \\
\hline Mg\# & 38,78 & 47,93 & 43,54 & 43,89 & 34,78 & 50,83 \\
\hline A/CNK & 1,23 & 1,21 & 1,46 & 1,33 & 1,43 & 1,31 \\
\hline $\mathrm{FeO}(\mathrm{T})$ & 2,87 & 4,59 & 4,23 & 3,55 & 1,87 & 1,43 \\
\hline $\mathrm{Ba}$ & 657 & 722 & 856 & 656 & 389 & 553 \\
\hline $\mathrm{Cl}$ & bdl & bdl & bdl & 135 & bdl & bdl \\
\hline Co & 23 & 31 & 29 & 27 & 19 & 21 \\
\hline $\mathrm{Cr}$ & 33 & 59 & 54 & 43 & 10 & 8 \\
\hline $\mathrm{Cu}$ & 24 & 35 & 48 & 22 & 7 & 10 \\
\hline $\mathrm{F}$ & 587 & 878 & 527 & 546 & 606 & 412 \\
\hline $\mathrm{Ga}$ & 14 & 19 & 16 & 16 & 18 & 15 \\
\hline $\mathrm{Nb}$ & 10 & 11 & 11 & 11 & 15 & 13 \\
\hline $\mathrm{Ni}$ & 10 & 27 & 20 & 16 & 5 & 4 \\
\hline $\mathrm{Pb}$ & 19 & 6 & 21 & 30 & 38 & 21 \\
\hline $\mathrm{Rb}$ & 74 & 117 & 118 & 113 & 191 & 160 \\
\hline S & 42 & 968 & bdl & 966 & bdl & bdl \\
\hline Sc & 6 & 14 & 6 & 8 & 4 & bdl \\
\hline $\mathrm{Sr}$ & 189 & 232 & 193 & 174 & 54 & 68 \\
\hline Th & 15 & 14 & 8 & 8 & 2 & 6 \\
\hline U & bdl & bdl & bdl & bdl & 6 & bdl \\
\hline V & 54 & 87 & 88 & 71 & 19 & 18 \\
\hline$Y$ & 25 & 139 & 31 & 21 & 25 & 26 \\
\hline $\mathrm{Zn}$ & 40 & 92 & 81 & 67 & 43 & 47 \\
\hline $\mathrm{Zr}$ & 147 & 268 & 303 & 178 & 130 & 121 \\
\hline $\mathrm{Hf}$ & 3,73 & 5,73 & - & 3,80 & - & 2,99 \\
\hline La & 30,8 & 32,1 & - & 25,4 & - & 22,7 \\
\hline $\mathrm{Ce}$ & 61,5 & 67,0 & - & 50,7 & - & 48,2 \\
\hline $\mathrm{Nd}$ & 26,1 & 30,4 & - & 21,3 & - & 21,7 \\
\hline $\mathrm{Sm}$ & 6,04 & 8,23 & - & 5,01 & - & 5,42 \\
\hline $\mathrm{Eu}$ & 1,03 & 1,41 & - & 1,07 & - & 0,81 \\
\hline $\mathrm{Gd}$ & 5,62 & 11,7 & - & 4,33 & - & 5,21 \\
\hline Dy & 4,77 & 17,8 & - & 3,21 & - & 5,92 \\
\hline Er & 2,48 & 17,7 & - & 1,93 & - & 2,65 \\
\hline $\mathrm{Yb}$ & 2,38 & 15,1 & - & 2,09 & - & 2,48 \\
\hline Lu & 0,34 & 2,22 & - & 0,30 & - & 0,34 \\
\hline
\end{tabular}


Encarte 6. CONT. Análises geoquímicas de granitos gnaissicos e stocks graníticos da C. Central .

IGM-8135 IGM-8143 IGM-80076 IGM-8607 IGM-8640 VRE-6A UN-4525 VRE-17ma VRE-17mb

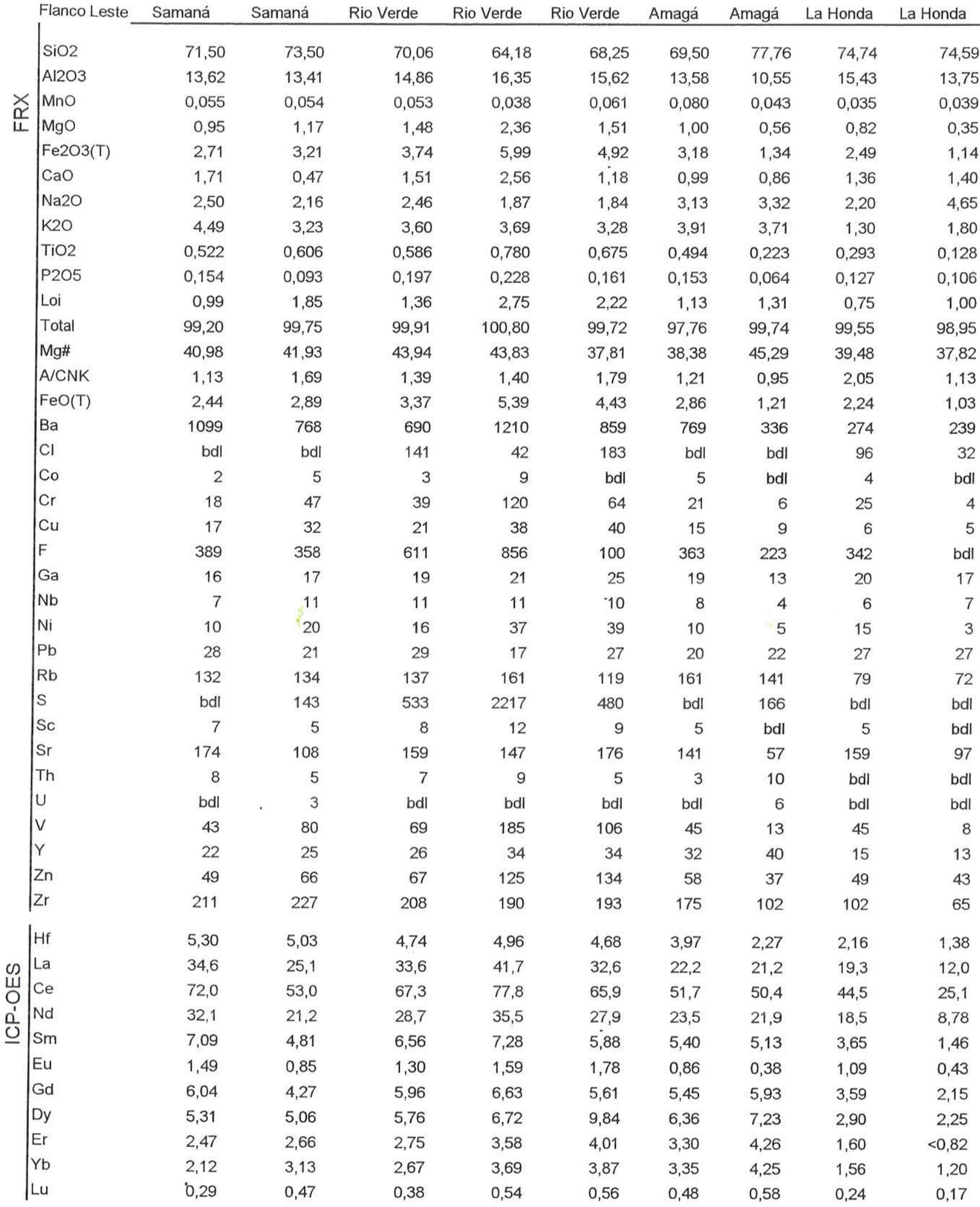


Encarte 6. CONT. Análises geoquímicos de granitóides do Complexo Metamórfico de El Oro.

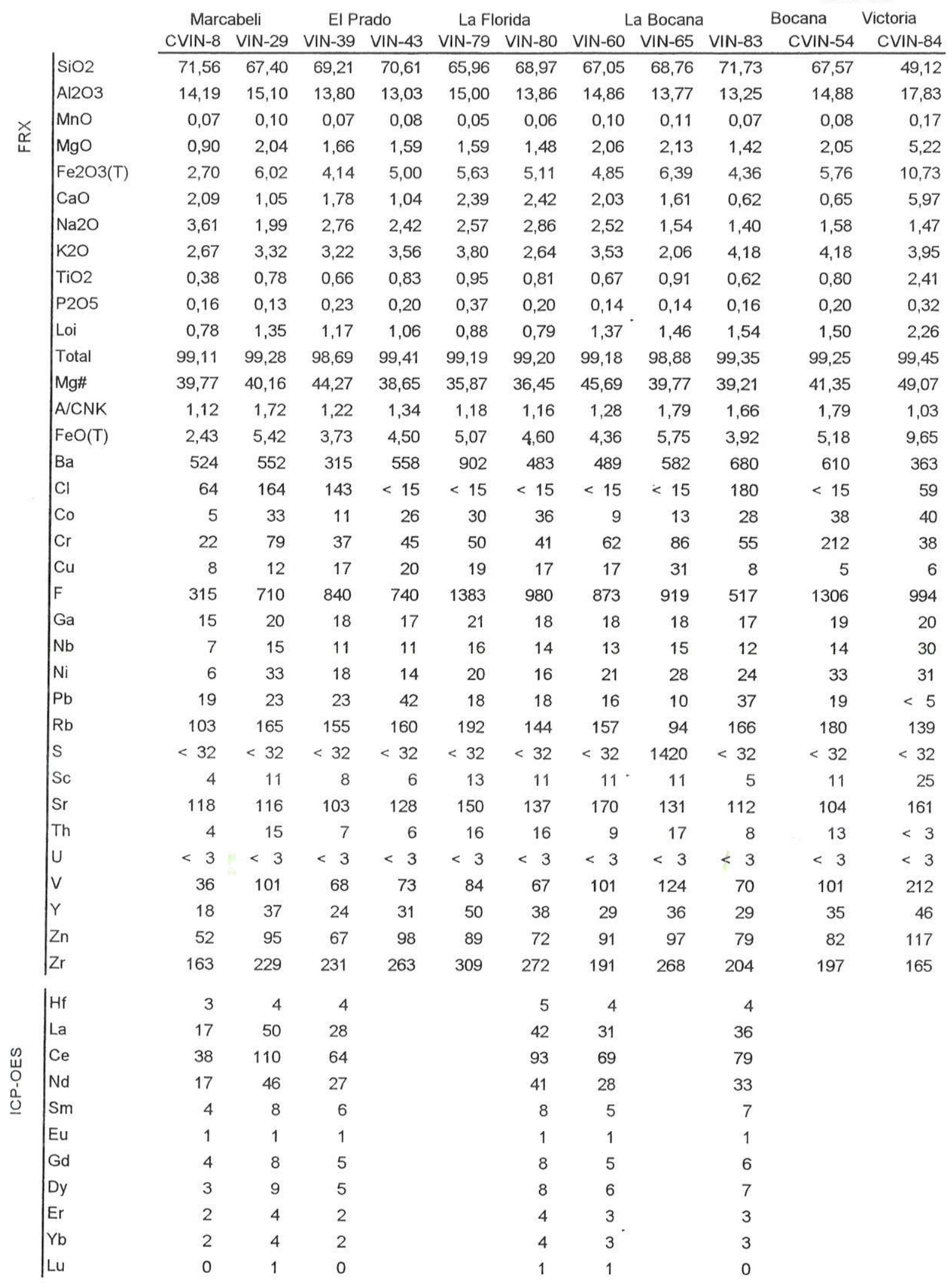


Encarte 6. CONT.Análises geoquímicos de granitóides da C. Real.

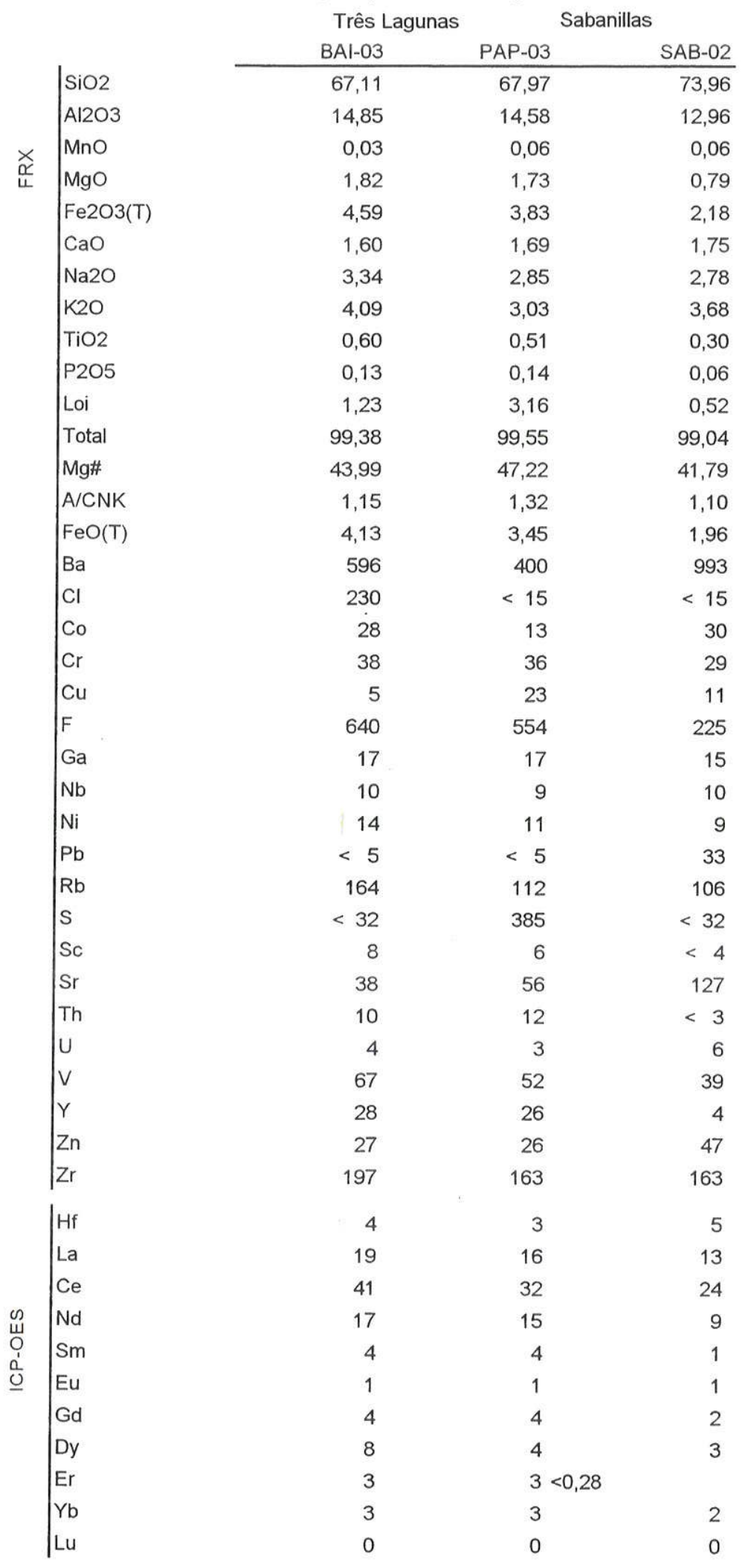


Encarte 7. Dados isotópicos U.Pb SHRIMP em zircão.

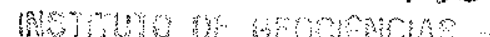

$T 436$

cos 知

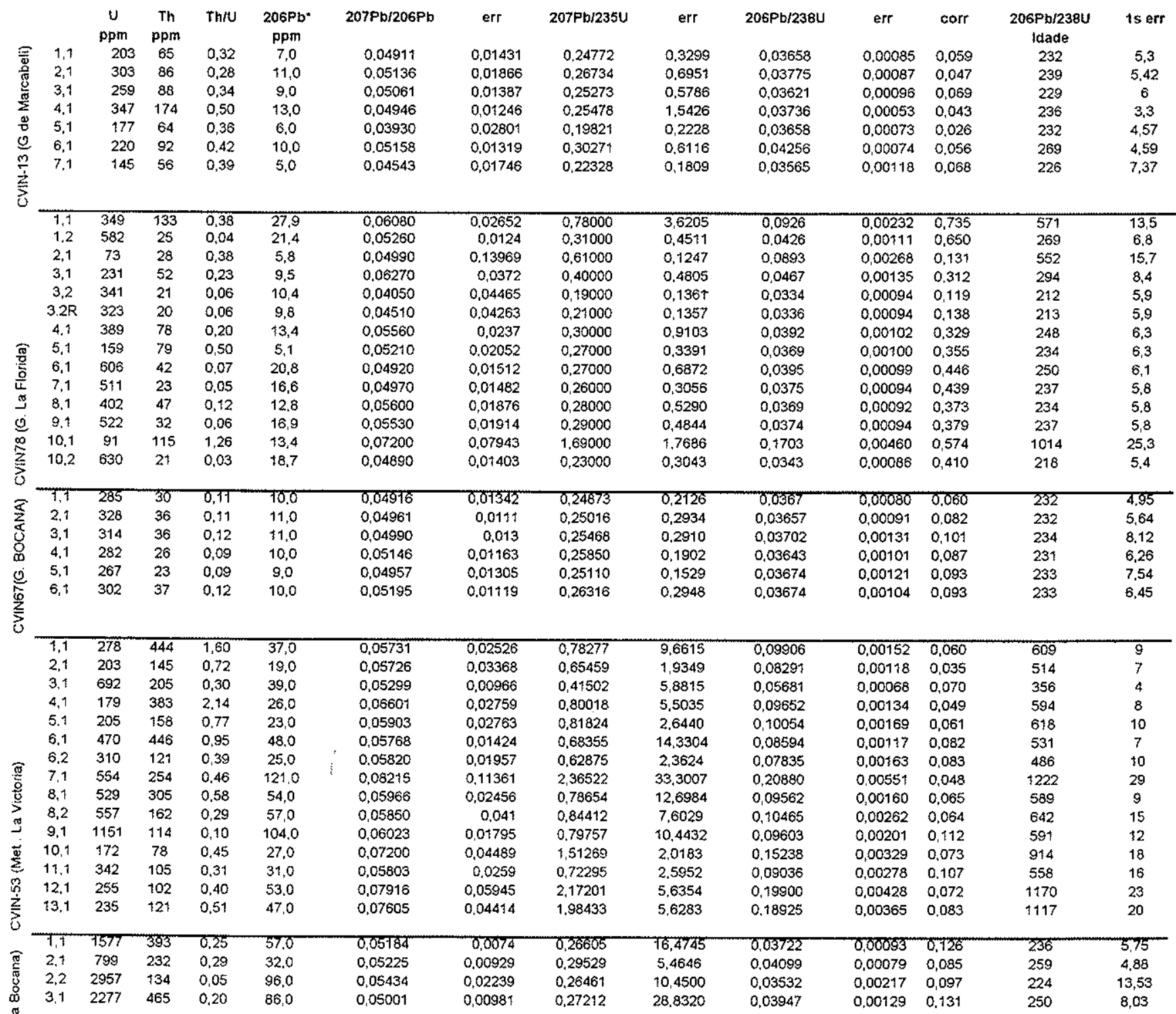

$\ddot{8}$

志

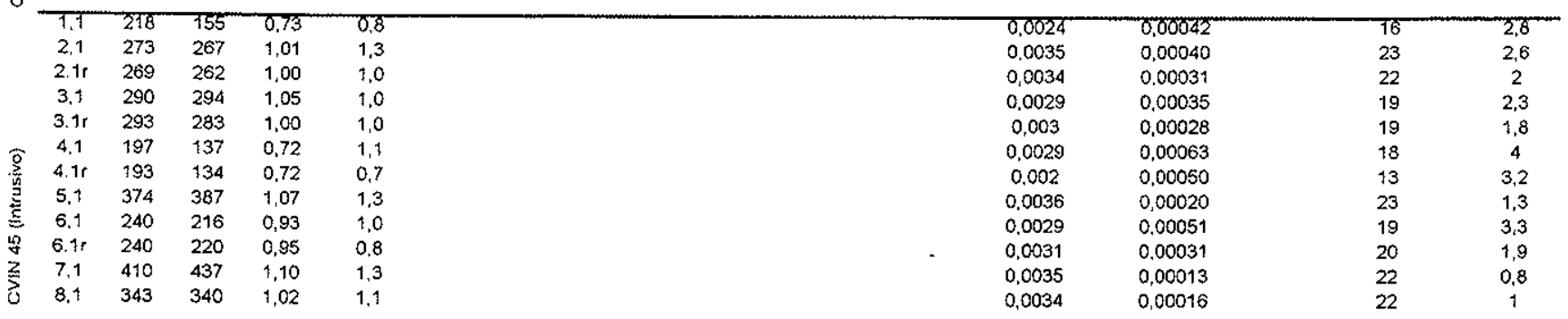

Erros são 1-sigma.

$\mathrm{Pb}$ comum corrigido usando $204 \mathrm{~Pb}$. 
Encarte 8. Dados Geocronológicos do Complexo metamórfico El Oro.

\begin{tabular}{|c|c|c|c|}
\hline Unidade & Método & Idade. & Referência \\
\hline \multirow[t]{8}{*}{ Unidade Piedras-Anfibolito } & $\mathrm{K}-\mathrm{Ar} / \mathrm{Hb}$ & $224 \pm$ & Aspden et al., 1992 \\
\hline & $\mathrm{K}-\mathrm{Ar} / \mathrm{Hb}$ & $647 \pm$ & Aspden et al., 1992 \\
\hline & $\mathrm{K}-\mathrm{Ar} / \mathrm{Hb}$ & $743 \pm$ & Kennerly, 1980 \\
\hline & $\mathrm{K}-\mathrm{Ar} / \mathrm{Hb}$ & $196 \pm$ & Feininger e Silberman, 1982 \\
\hline & $\mathrm{K}-\mathrm{Ar} / \mathrm{Hb}$ & $74 \pm$ & Feininger e Silberman, 1982 \\
\hline & $\mathrm{K}-\mathrm{Ar} / \mathrm{Hb}$ & $72 \pm$ & Aspden et al., 1992 \\
\hline & $\mathrm{K}-\mathrm{Ar} / \mathrm{Hb}$ & $74 \pm$ & Aspden et al., 1992 \\
\hline & $\mathrm{K}-\mathrm{Ar} / \mathrm{Hb}$ & $76 \pm$ & Aspden et al., 1992 \\
\hline \multirow[t]{3}{*}{ La Victoria-Granada gneisses } & $\mathrm{K}-\mathrm{Ar} / \mathrm{Bi}$ & $211 \pm$ & Aspden et al., 1992 \\
\hline & $\mathrm{K}-\mathrm{Ar} / \mathrm{Mu}$ & $213 \pm$ & Aspden et al., 1992 \\
\hline & K-Ar/Mu & $207 \pm$ & Aspden et al., 1992 \\
\hline \multirow[t]{3}{*}{ La Victoria-gneisses pegmatiticos } & K-Ar/Mu & $220 \pm$ & Aspden et al., 1992 \\
\hline & $\mathrm{K}-\mathrm{Ar} / \mathrm{Bi}$ & $216 \pm$ & Aspden et al., 1992 \\
\hline & $\mathrm{K}-\mathrm{Ar} / \mathrm{Mu}$ & $189 \pm$ & Aspden et al., 1992 \\
\hline \multirow[t]{4}{*}{ Granito Marcabelí } & $\mathrm{K}-\mathrm{Ar} / \mathrm{Mu}$ & $214 \pm$ & Aspden et al., 1992 \\
\hline & $\mathrm{K}-\mathrm{Ar} / \mathrm{Bi}$ & $201 \pm$ & Aspden et al., 1992 \\
\hline & K-Ar/Mu & $193 \pm$ & Aspden et al., 1992 \\
\hline & $\mathrm{K}-\mathrm{Ar} / \mathrm{Bi}$ & $221 \pm$ & Aspden et al., 1992 \\
\hline Biotita Granada gneisse-La Bocana & $\mathrm{K}-\mathrm{Ar} / \mathrm{Bi}$ & $210 \pm$ & Feininger e Silberman, 1982 \\
\hline \multirow[t]{3}{*}{ Biotita Ortogneisse-La Bocana } & $\mathrm{K}-\mathrm{Ar} / \mathrm{Bi}$ & $211 \pm$ & Aspden et al., 1992 \\
\hline & $\mathrm{K}-\mathrm{Ar} / \mathrm{Mu}$ & $213 \pm$ & Aspden et al., 1992 \\
\hline & $\mathrm{K}-\mathrm{Ar} / \mathrm{Mu}$ & $207 \pm$ & Aspden et al., 1992 \\
\hline \multirow[t]{2}{*}{ Biotita Muscovita granodiorito-La Bocana } & $\mathrm{K}-\mathrm{Ar} / \mathrm{Bi}$ & $216 \pm$ & Aspden et al., 1992 \\
\hline & K-Ar/Mu & $220 \pm$ & Aspden et al., 1992 \\
\hline Muscovita pegmatito com Turmalina & K-Ar/Mu & $189 \pm$ & Aspden et al., 1992 \\
\hline La Bocana-Paragneisse (Paleosoma) & Is. Sm-Nd & $219 \pm$ & Aspden et al., 1992 \\
\hline Granito Marcabelí & U-Pb Monacita & $227,5 \pm 0,8$ & Noble et al., 1997 \\
\hline Unidade Piedras-Anfibolito & U-Pb Zircão & $221 \pm 181$ & Noble et al., 1997 \\
\hline Granito Limón Playa & U-Pb Zircão & $200 \pm$ & Noble et al., 1997 \\
\hline
\end{tabular}


Encarte 9. Dados Geocronológicos da Cordilhiera Real em corpos Permo-Triássicos

\begin{tabular}{|c|c|c|c|}
\hline Unidade & Método & Idade & Referência| \\
\hline \multirow[t]{3}{*}{ Agoyán-Granada gneisses } & K-Ar/Mica & $78 \pm 23$ & Aspden et al., 1992 \\
\hline & K-Ar/Mica & $74 \pm 27$ & \\
\hline & K-Ar/Mica & $75 \pm 7$ & \\
\hline \multirow[t]{7}{*}{ Papallacta-Granada gneisses, Anfibolito } & $\mathrm{K}-\mathrm{Ar} / \mathrm{Hb}$ & $363 \pm .9$ & \\
\hline & $\mathrm{K}-\mathrm{Ar} / \mathrm{Hb}$ & $371 \pm 10$ & \\
\hline & $\mathrm{K}-\mathrm{Ar} / \mathrm{Hb}$ & $342 \pm 23$ & \\
\hline & $\mathrm{K}-\mathrm{Ar} / \mathrm{Hb}$ & $306 \pm 10$ & \\
\hline & $\mathrm{K}-\mathrm{Ar} / \mathrm{Bi}$ & $844 \pm 20$ & \\
\hline & K-Ar/Bi & $881 \pm 44$ & \\
\hline & $\mathrm{K}-\mathrm{Ar} / \mathrm{Mu}$ & $74 \pm 3$ & \\
\hline \multirow[t]{11}{*}{ Unidade Sabanilla-Granada gneisses } & $\mathrm{K}-\mathrm{Ar} / \mathrm{mu}$ & $128 \pm 6$ & \\
\hline & $\mathrm{K}-\mathrm{Ar} / \mathrm{Hb}$ & $135 \pm 8$ & \\
\hline & $\mathrm{K}-\mathrm{Ar} / \mathrm{Bi}$ & $76 \pm 3$ & \\
\hline & $\mathrm{K}-\mathrm{Ar} / \mathrm{mu}$ & $77 \pm 3$ & \\
\hline & $\mathrm{K}-\mathrm{Ar} / \mathrm{mu}$ & $65 \pm 2$ & \\
\hline & $\mathrm{K}-\mathrm{Ar} / \mathrm{Bi}$ & $72 \pm 2$ & \\
\hline & $\mathrm{K}-\mathrm{Ar} / \mathrm{mu}$ & $69 \pm 2$ & \\
\hline & $\mathrm{K}-\mathrm{Ar} / \mathrm{Bi}$ & $85 \pm 2$ & \\
\hline & $\mathrm{K}-\mathrm{Ar} / \mathrm{mu}$ & $73 \pm 3$ & \\
\hline & $\mathrm{K}-\mathrm{Ar} / \mathrm{Bi}$ & $81 \pm 2$ & \\
\hline & $\mathrm{K}-\mathrm{Ar} / \mathrm{Bi}$ & $82 \pm 2$ & \\
\hline \multirow[t]{9}{*}{ Unidade Sabanilla-Ortogneisse } & $\mathrm{K}-\mathrm{Ar} / \mathrm{Bi}$ & $82 \pm 3$ & \\
\hline & $\mathrm{K}-\mathrm{Ar} / \mathrm{Bi}$ & $82 \pm 3$ & \\
\hline & $\mathrm{K}-\mathrm{Ar} / \mathrm{Bi}$ & $82 \pm 3$ & \\
\hline & $\mathrm{K}-\mathrm{Ar} / \mathrm{mu}$ & $66 \pm 2$ & \\
\hline & $\mathrm{K}-\mathrm{Ar} / \mathrm{Bi}$ & $84 \pm 3$ & \\
\hline & $\mathrm{K}-\mathrm{Ar} / \mathrm{mu}$ & $66 \pm 2$ & \\
\hline & $\mathrm{K}-\mathrm{Ar} / \mathrm{Bi}$ & $86 \pm 2$ & \\
\hline & $\mathrm{K}-\mathrm{Ar} / \mathrm{Bi}$ & $83 \pm 2$ & \\
\hline & K-Ar/Bi & $97 \pm 3$ & \\
\hline \multirow[t]{14}{*}{ Granito Tres Lagunas } & $\mathrm{K}-\mathrm{Ar} / \mathrm{Bi}$ & $81 \pm 3$ & \\
\hline & $\mathrm{K}-\mathrm{Ar} / \mathrm{Bi}$ & $86 \pm 4$ & \\
\hline & $\mathrm{K}-\mathrm{Ar} / \mathrm{mu}$ & $100 \pm 3$ & \\
\hline & $\mathrm{K}-\mathrm{Ar} / \mathrm{Bi}$ & $65 \pm 9$ & \\
\hline & $\mathrm{K}-\mathrm{Ar} / \mathrm{mu}$ & $99 \pm 3$ & \\
\hline & $\mathrm{K}-\mathrm{Ar} / \mathrm{Bi}$ & $63 \pm 3$ & \\
\hline & $\mathrm{K}-\mathrm{Ar} / \mathrm{mu}$ & $99 \pm 3$ & \\
\hline & K-Ar/Bi & $65 \pm 2$ & \\
\hline & $\mathrm{K}-\mathrm{Ar} / \mathrm{mu}$ & $68 \pm 3$ & \\
\hline & $\mathrm{K}-\mathrm{Ar} / \mathrm{Bi}$ & $62 \pm 2$ & \\
\hline & $\mathrm{K}-\mathrm{Ar} / \mathrm{mu}$ & $73 \pm 2$ & \\
\hline & $\mathrm{K}-\mathrm{Ar} / \mathrm{mu}$ & $50 \pm 2$ & \\
\hline & $\mathrm{K}-\mathrm{Ar} / \mathrm{mu}$ & $69 \pm 2$ & \\
\hline & $\mathrm{K}-\mathrm{Ar} / \mathrm{Bi}$ & $62 \pm 2$ & \\
\hline Unidade Sabanillas-Ortogneisse & Is. $\mathrm{Rb}-\mathrm{Sr}$ & $224 \pm 37$ & \\
\hline Granito Tres Lagunas & Is. $\mathrm{Rb}-\mathrm{Sr}$ & $200 \pm 12$ & \\
\hline Granito Tres Lagunas & U-Pb/Mon & $227 \pm 2,2$ & \\
\hline
\end{tabular}


Encarte 10. Dados isotópicos U-Pb SHRIMP em zircão.

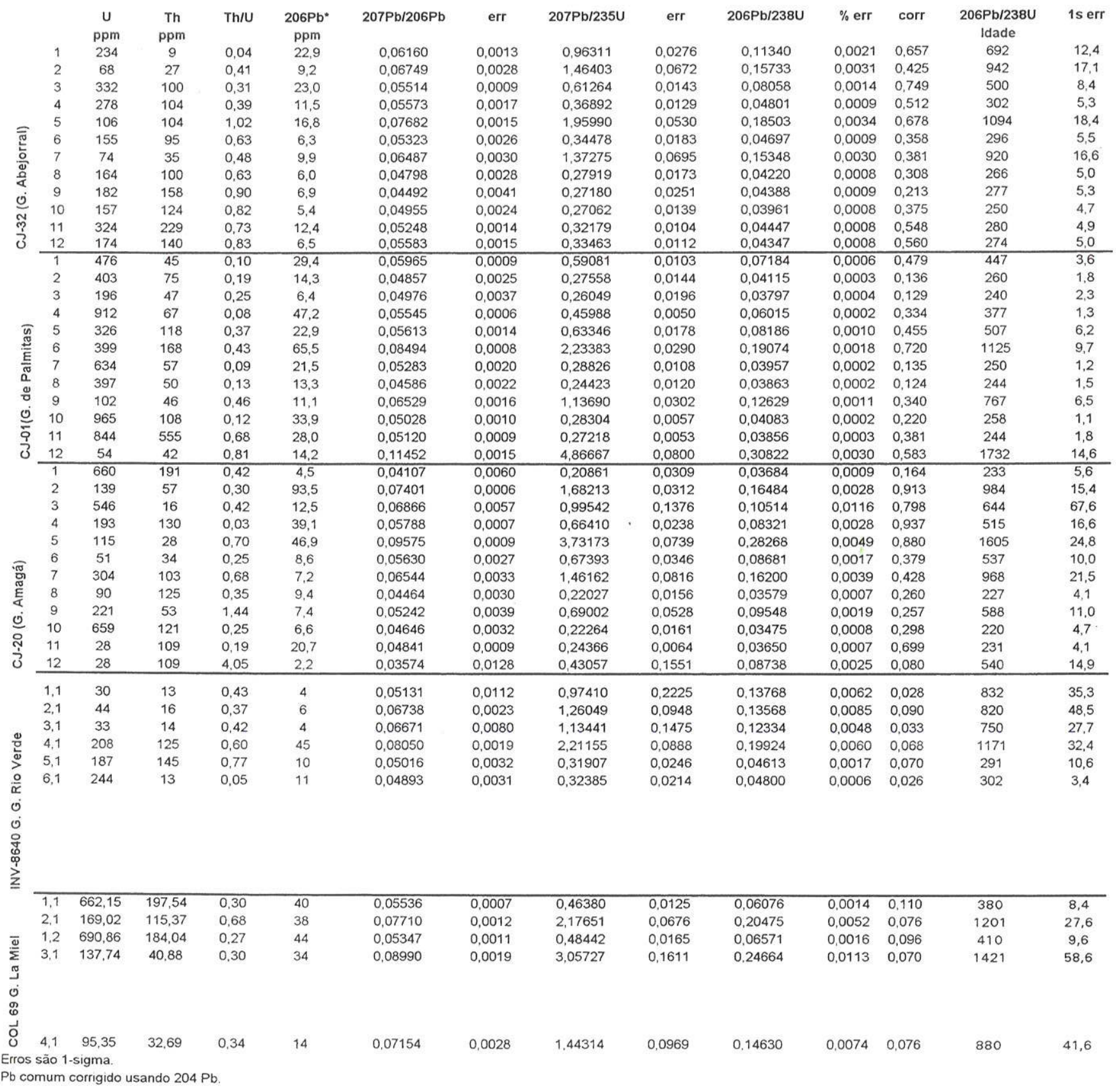

